\title{
Herstel en revalidatie na hartinfarct
}

Citation for published version (APA):

Diederiks, J. P. M. (1982). Herstel en revalidatie na hartinfarct. [Doctoral Thesis, Maastricht University]. Rijksuniversiteit Limburg. https://doi.org/10.26481/dis.19820610jd

Document status and date:

Published: 01/01/1982

DOI:

10.26481/dis.19820610jd

Document Version:

Publisher's PDF, also known as Version of record

\section{Please check the document version of this publication:}

- A submitted manuscript is the version of the article upon submission and before peer-review. There can be important differences between the submitted version and the official published version of record.

People interested in the research are advised to contact the author for the final version of the publication, or visit the DOI to the publisher's website.

- The final author version and the galley proof are versions of the publication after peer review.

- The final published version features the final layout of the paper including the volume, issue and page numbers.

Link to publication

\footnotetext{
General rights rights.

- You may freely distribute the URL identifying the publication in the public portal. please follow below link for the End User Agreement:

www.umlib.nl/taverne-license

Take down policy

If you believe that this document breaches copyright please contact us at:

repository@maastrichtuniversity.nl

providing details and we will investigate your claim.
}

Copyright and moral rights for the publications made accessible in the public portal are retained by the authors and/or other copyright owners and it is a condition of accessing publications that users recognise and abide by the legal requirements associated with these

- Users may download and print one copy of any publication from the public portal for the purpose of private study or research.

- You may not further distribute the material or use it for any profit-making activity or commercial gain

If the publication is distributed under the terms of Article $25 \mathrm{fa}$ of the Dutch Copyright Act, indicated by the "Taverne" license above, 


\section{HERSTEL EN REVALIDATIE}

NA HARTINFARCT

\section{PROEFSCHRIFT}

ter verkrijging van de graad van doctor in de geneeskunde aan de Rijksuniversiteit Limburg te Maastricht op gezag van de Rector Magnificus Dr. H.C. Hemker, volgens besluit van het college dex Dekanen in het openbaar te verdedigen op donderdag 10 juni 1982 des namidaags om vier uur precies, in de aula van de universiteit.

\section{door}

Joseph Petrus Maria Diederiks geboren te Rotterdam in 1944 
Promotor: Prof.Dr. H. Philipsen

Referenten: Prof.Dr. J.M.G. Persoon

Prof.Dr. H.J.J. Wellens

Het verschijnen van dit proefschrift werd mede mogelijk gemakt door steun van de Nederlandse Hartstichting. 
'The ain of the experiment was to detect those who did not approve of its being carried out and to take appropxiate steps.'

A. Zinoviev, The Yawning Heights, 1979. 
Manuscript: mw Lenneke Roijen-Warnars

Omslag en tekeningen: Guus van Rooy

Druk: Ben Meerstad 


\section{Inhoudsopgave}

Voorwoord

pag.

Hoofdstuk 1 Herstel en revalidatie: aard en omvang van het probleem

1.1 Inleiaing

1.2 Drie benaderingen van herstel en haxtinfarct

1.3 Herstel nader bezien

1.4 Drie aspekten van herstel na hartinfarct

1.5 Relaties tussen fysiek, psychisch en socilaal herste 1

1.6 De invloed van revalidatie op herstel

1.7 Nabeschouwing

Hoofdstuk 2 Probleemstelling en opzet van de twee betrokken onderzoeken

2.1 Inleiding

2.2 Het CARGO-onderzoek

2.3 Het Leidse onderzoek

Hoofdstuk 3 Beschrijving van de onderzoeksgroepen

3.1 Het CARGo-onderzoek

3.2 Het Leidse onderzoek

55

3.3 Metodische opmerkingen

Hoofdstuk 4 werkhervatting als objektief herstel; resultaten van het CARGO-onderzoek 63

4.1 Inleiding

4.2 Werkhervatting na hartinfarct in hoofdijnen 63

4.3 Faktoren die samenhangen met hervatting 68

4.4 Sukses van hervatting 83

4.5 Faktoren die samenhangen met sukses van hervatting

4.6 Samenvatting en diskussie

Hoofdstuk 5 Werkhervatting als subjektief herstel 94

5.1 Inleiding 94

5.2 Oordeel van patiënt en bedrijfsarts over sukses hervatting

5.3 Hervatting en algemene tevredenheid 102

5.4 Samenvatting en diskussie 104

5.5 Nabeschouwing CARGO-onderzoek 105 
pag.

Hoofdstuk 6 De invloed van revalidatie op herste1:

resultaten van het Leidse onderzoek 108

6.1 Inleiding

6.2 objektief fysiek herstel

108

6.3 Objektief psychisch herste1

108

6.4 objektief sociaal herstel

113

6.5 Subjektief hersted

6.6 Revalidatie en de partner

123

6.7 Samenvattende analyse

125

6.8 Het Ieidse onderzoek: samenvatting en diskussie 137

Hoofdstuk 7 Werkhervatting, revalidatie en coping strategie

7.1 Inleiding

7.2 Revalidatie en werkhervatting

7.3 Faktoren die met werkhervatting samenhangen: coping strategie

7.4 Samenvattende analyse werkhervatting in het Leidse onderzoek

7.5 Samenvatting er diskussie

Hoofdstuk 8 Samenvatting en diskussie onderzoeksresultaten

8. 1 CARGo-onderzoek

8.2 Het Leidse onderzoek

8.3 Teoretische betekenis van de onderzoeksresultaten

8.4 Praktische betekenis van de onderzoeksresultaten

It teratum

Bijlagen

Curriculum vitae 


\section{Voorwoord}

Dit proefschrift is gebaseerd op twee onderzoeken die inhoudelijk veel, maar naar karakter en uitvoering weinig gelijkenis vertonen.

Historisch gezien is het Leidse onderzoek (Evaluatie van poliklinische hartrevalidatie), een kleinschalig experiment naar de effekten van hartrevalidatie, het oudste. Opzet en uitvoering van dit onderzoek zijn tot stand gekomen in een samenwerking tussen het NIPG-TNO en de afdeling Cardiologie van het Academisch Ziekenhuis te Leiden. Sleutelfiguren in dit projekt waren vooral Hans weeda, Michel Schobre en Henk van der Sluijs; in de beginfase waren dat Jacques Josten, Ali kulpers en het revalidatieteam van Katwijk, in het bijzonder Atie de Niet en Peter Molhoek. Met Hans, Michel en Henk is in de loop van het projekt een bijzonder hechte samenwerking ontstaan. Met waardering kunnen hier ook de adviezen van Paul van Leeuwen en Wim van Nooten van de afdeling statistiek van het NIPGTNo worden gememoreerd. Voor de totstandkoming van het projekt hebben Prof.Dr. A.C. Arntzenius vanwege het AZL en Dr. M.J. Hartgerink, toenmalig direkteur van het NIPGTNO, de noodzakelijke voorwaarden geschapen. Laatstgenoemde en de promotor, Prof.Dr. H. Philipsen, hebben de transfer van het projekt van Leiden naar Maastricht mogelijk gemaakt.

Het tweede onderzoek is een beschrijvend onderzoek naar werkhervatting na hartinfarct en de faktoren die daarmee samenhangen. Dit onderzoek heeft zijn oorsprong in de Nederlandse Vereniging voor Arbeids- en Bedrijfsgeneeskunde (NVAB) en de Commissie voor Arbeidsgeneeskundig onderzoek (CARGO-TNO). Aan de wieg van dit onderzoek stonden: Dr. J. Jongh, destijds koördinator van de CARGO-TNO, Dx. J. Baart, Dr. Tj. de Boorder, A. Friedhoff, mw. C. van veelen, R.E. Wiggers, Ch. Wijnveldt en $G$. Ragay. Voor de uitvoering zijn de 42 deelnemende bedrijfsartsen en de administratieve ondersteuning van Marlou Huijgen onontbeerlijk geweest. De rapportage kwam tot stand onder het kritische oog van de begeleidingscommissie, die naast Jongh, Friedhoff, mw. van Veelen en Ragay bestond uit: $\mathbb{P}$. van Leeuwen, mw. Dr. M. Pais, Prof.Dr. H. Philipsen, Prof.Dr. R.S. Reneman en Dr. J.J.F. Schmitz. 
Bij de produktie van dit proefschrift is de inbreng van een aantal personen essentieel geweest. Henk Lebens was behulpzaam bij de computerverwerking. Zeker niet onvermeld mag blijven dat Lenneke Roijen, ondanks naar arbeidsinspektie-maatstaven laakbare arbeidsomstandigheden, exin slaagde de uiteindelijke vormgeving van het manuscript te verzorgen. Daarnaast moet ook het feit, dat Guus van Rooy in geblesseerde toestand het tekenwerk verzorgde, voor het nageslacht bewaard blijven.

Marga Doyle bleek, net terug van een wereldreis, bereid het manuscript voor betreffende onderdelen te bezien op het Engels.

Bijzondere erkentelijkheid moet worden uitgesproken over de adviezen van de promotor Prof.Dr. H. Philipsen, waardoor het mogelijk was voortdurend de grote lijn vast te houden. Dank geldt ook de beide referenten Prof.Dr. J.M.G. Persoon en prof.Dr. H.J.J. Wellens voor hun kritische kommentaar op het manuscript.

Tenslotte dank ik de leden van de capacitejtsgroep Medische Sociologie, in het bijzonder de voorzitter Riet Drop, voor het getoonde begrip ten aanzien van het selektieve geheugenverlies waaraan een promovendus in de laatste fase wel eens wil lijden. 


\section{Herstel en revalidatie: Aard en omvang van het probleem}

\section{1 Inleiding}

Het acute hartinfarct $\mathrm{kan}$ in het algemeen worden beschouwd als een dramatische gebeurtenis in het leven van een mens. Het vaak plotseling optreden, de onmiddelijjke levensbedrelging en de spectaculair ogende eerste opvang, markeren de beginfase van het leven als hartpatient. De belangstelling van gezondheidszorg en maatschappij gaat dan ook bijna als vanzelfsprekend vooral uit naar juist deze fase.

Voor de overlevende begint echter na het ontslag uit het ziekenhuis de aanzienlijk minder spectaculaire fase van het herstel. Nog behept met meestal niet onaanzienlijke angsten, mar nu niet meer verkerend in de betrekkelijk veilige en beschermende omgeving van het ziekenhuis, moet hij trachten zich aan te passen aan de nieuwe situatie en zijn leven opnieuw in te richten.

Vanzelfsprekend is niet voor iedereen die door een hartinfarct wordt getroffen het verloop gelijk aan het hierboven geschetste. Van de circa 40.000 personen die in Nederland jaarlijks door deze aandoening worden getroffen is ongeveer een kwart overleden voordat de gezondheidszorg er aan te pas is gekomen. Van degenen die wel in de gezondheidszorg terecht komen wordt circa $90 \%$ in een ziekenhuis opgenomen.

Na een jaar is de helft van het oorspronkelijke aantal getroffenen nog in leven. Het proces van anpasing en herstel geldt dus jaarlijks ruim 20.000 personen, 16.000 mannen en 4.000 vrouwen. Voor de arbeidzame levensfase, dus onder de 65 jaar, geldt dit rulm 15.000 personen, 12.000 mannen en 3.000 vrouwen (Commissie Coördinatie onderzoek Hart- en Vaatziekten TNO, 1980).

Vanuit de gezondheldszorg gezien gatt het erom, na de opvang in het acute stadium, het herstel van de patient in positieve zin te beinvloeden. Hierbij dient een onderscheid te worden gemaakt tussen een medisch-somatische beinvloeding en een benadering die uitgaat van wat wel het revalidatie-model wordt genoemd (Weeda en Visser, 1981). De medisch-somatische 
benadering, die konservatlef of chinurgisch kan zijn, beoogt de levensduur te verlengen en het optreden van komplikaties te vooxkomen. Revalidatie is er echter op gericht het funktioneren van de patient, in lichamelijk, psychisch en sociaal opicht te verbeteren. In de behandeling zijn beide benaderingen komplementair aan elkaar (Weeda en visser, 1981).

In de navolgende onderzoeken gaat het globaal gesproken over de vraag of en in hoeverre revalidatie bijaraagt aan het herstel van mannelijk hartinfarctpatienten in de arbeidzame levensfase. De nadruk zal daarbij komen te liggen op de psychosoclale aspekten van het herstel. Alvorens over te gaan tot het formulexen van de precieze vraagstelingen, dient allereerst te worden nagegaan wat verstaan wordt onder herstel en wat hierover bekend is middels empirisch onderzoek. Daarna zal worden ingegaan op het begrip revalidatie en een overzicht worden gegeven van de stand van zaken met betrekking tot de huidige kennis van de bijarage van revalidatie aar het herstel.

\subsection{Drie benaderingen van herstel na hartinfarct}

Begrippen

Genezing is een begrip dat op het eerste oog nawwe verwantschap vertoont met de term herstel. Toch komt het begrip in de 1 iteratur betreffende de post-infarct problematiek niet of nauwelijks voor.

Aangezien genezing (cure) in het algemeen als een somatisch herstel, dat wil zeggen een herstel in het pathologisch-anatomisk substrat, wordt opgevat, is dit ook begrijpelijk. Vanuit dit gezichtspunt is immers voor het hartinfarct herstel op te vatte als de littekenvorming. in dat deel van het myocard dat door onvoldoende zuurstoftoevaer necrotisch is geworden. Dit proces neemt a thankelijk van de grootte van het infarct, enkele weken tot enkele manden in beslag. Het is echter duidelijk onzinnig alleen op basis hiervan te beweren dat een hartinfarctpatient na enkele weken hersteld is. om te beginnen is ex sprake van konditieveriles door de bedrust. Vervolgens duurt verwerking van het psychisch trauma in het algemeen veel langer. Tenslotte moet men zich realiseren dat het hartinfarct in verreweg de meeste gevallen een uiting is van het progressief verlopend proces van atherosclerose. De inmidals in zwang zijnde terminologie bestaat uit twee 
nauw verwante begrippen: herstel (recovery) en reconvalescentie (convalescence). Deze begrippen worden nogal eons door elkaar gebruikt en in feite bestal taalkuralg slechts een nuanceverschil: bij recovery stat het idee van aktief herstellem voorop, terwijl met convalescence het herstellend zijn als zodanig aangeduid wordt. In het vervolg aal het begrip herstel worden gevat als identiek in betekenis met recovery, terwijl reconvalescentie slechts zijdelings wordt gebruikt.

In de literatur vindt men geen expliciete definities van herste1, meestal wordt volstaan met de aanduiding dat het hier gaat om een complex, adaptief proces (Croog, cevine en Lurie, 1968; Doehrman, 1977; Weeda en visser, 1981). De impliciete definitie gaat blijkbaar uit van de gedachte dat herstel een proces van aanpassing is aan de gevolgen van de $z$ ilekte. Deze gedachtengang heeft echter enkele belangrijke problemen.

Het belangrijkste bezwaar is wel dat lang niet altijd onderscheld kan worden gemaakt tussen de gevolgen sec en aanpassingsverschijnselen. Bijvoorbeeld: is het optreden van depressieve symptomen na een hartinfarct nu een gevolg hiervan of is het een fase in het normale aanpassingsproces?

vervolgens kan het vermoeden bestaan dat bepaalde verschijnselen reeds vó́r het infarct aanwezig waren en dus eerder als oorzakelijke faktoren beschouwd moeten worden. Niettegenstaande het ontbreken van een duidelijke omschrijving van het begrip herstel $\mathrm{kan}$ de literatuur in drie hoofdrichtingen, die overigens weinig aandacht besteden aan fysiek herstel, worden ondergebracht.

In een latere fase zal opnieuw worden ingegaan op het begrip herstel, warna ook fysiek herstel zal worden behandeld.

\section{De psychodynamische benadering}

Het zijn vooral direkt bij de behandeling betrokken psychiaters en psychologen geweest die een psychodynamische benadering, min of meer het model van het rouwproces, hebben ontwikkeld voor het herstel na hartinfarct. Het typlsche rouwproces, volgend op het verlies van een naastbestaande, begint met een periode van shock en ongeloof. In deze periode kunnen ook protestreakties voorkomen. Na enige dagen treedt een fase van wanhoop op, die geparard gaat met depresslesymptomen als. 
apatie, een gevol van nutteloosheid, saapstoornissen, maag-en darmklachten, gebrek aar eetlust, rusteloosheid en prikkelbaarheid. Een neiging het verlies te ontkennen kan gedurende enige tija aanwezig zijn. Na enkele manden beginnen de symptomen te vermindexen en vindt een geleidelijke terugkeer naar het normale dagelijkse leven plaats (Janis, 1971).

Volgens Cassem en Hackett (1971) zijn de typische emotionele reakties op een hartinfaxct in de acute fase achtereenvolgens: angst door de levensbedreigende situatie en depressie door verlies van het gevoel van eigenwarade. Door ontkenning van de ernst, of zelfs van het feit van het infarct zelf, kunnen deze onaangename gevoelens teniet worden gedaan (Hackett en Cassem, 1973). Wanneer de patient eenmal naar huis terugkeert en nu pas goed merkt wat hij allemal niet meer kan, treedt in veel gevallen de $z .9$. homecoming depression op. ook hier is een gehele of gedeeltelijke ontkenning van de ernst en gevolgen van het infarct de meest suksesvolle coping strategie (Hackett en cassem. 1978). Vooral ten aanzien van het optreden van depressieve verschijnselen is sprake van een analogie met het rouwproces na het verlies van een nastbestaande. Het Hackett en Cassem-model legt er sterk de nadruk op dat angst, depressie en ontkenning als normale reakties moeten worden beschouwd teneinde in het reine te komen met het feit van het hartinfarct.

Het onderzoek naar a anleiding van het Hackett en cassemmodel bevestigt de bruikbaarheid ervan vooral voor de fase, warin de patient is opgenomen. Het meest aanvechtbare 1 ijkt echter de steling te zijn dat ontkenning een normale en suksesvolle coping strategie is (Doehrman, 1977; Krantz, 1980). Daarnaast is omstandig aangetoond dat depressies of depressieve symptomen, zals die beschreven zijn voor het typlsche rouwproces, enige manden na het infarct veelvildig voorkomen en een negatief effekt hebben op de psychische en socliale toestand van de patiënt én of twee jaar later (Dpehrman, 1977; Stern et al., 1976, 1977; Mayou et al. $1978^{b}$ ).

Cay et al. (1972) vonden dat angst en depressie vooral samenhangen met spanningen en problemen van vobr het infarct. Dit resultat geeft reden tot twijfel over de opvatting dat angst en depressie uitsluitend te zien zijn als reaktie op het infarct. Het onderzoek van Appels et al. (1979) wijst zelEs 
in de richting van depressie als prodroom van het hartinfarct. ook kan ontkenning van symptomen al vóx het infarct optreden (Simon et a1., 1972).

Het verschijnsel dat depressieve symptomen veelvuldig voorkomen en de opvatting dat het om een normale reaktie gaat, zouden de suggestie kunnen wekken dat het hiex een betrekkelijk invariant gegeven betreft. Het is ontegenzeggelijk waar dat weinig relaties worden gevonden tussen het optreden van depressies en mogelijk ervoor verantwoordelijke faktoren. Korte tijd na het hartinfarct 1 ijkt er echter een verband te bestaan tussen de ernst van het infarct en depressie (Parker en Hodge, 1967; Leigh et al., 1972). In de periode na ontslag wordt daarentegen in het algemeen geen verband gevonden tussen ernst-indikatoren en depressie (Cay et al. 1972). De relatie tussen het optreden van depressie en faktoren als leeftijd en sociale klasse is onduidelijk, dat wil zeggen somigen vinden wel en anderen geen verband (Rosen en Bibxing, 1966; Cay et a1., 1972; stern et al., 1976).

\section{KONKUUSIES}

De psychodynamische benadering beschrijft herstel in termen van emotionele reakties als angst, depressie en ontkenning. Het staat in elk geval redelijk vast dat depressieve symptomen gedurende enige maanden na het infarct eerder regel dan uitzondering $z i j n$. Het feit dat zo weinig verbanden worden gevonden tussen depressie en mogelijk verklarende faktoren lijkt dit te ondersteunen. In de visie van Hackett en Cassem zijn angst en depressie normale, elkaar opvolgende reakties op het infarct, terwijl ontkenning als een normale strategle wordt beschouwd om de onaangename emoties te boven te komen. Ex zijn echter ook onderzoeken vermeld, die laten zlen dat depressie al vór het infarct aanwezig is, dan wel verband houdt met spanningen en problemen in die periode. Hetzelfde kan gezegd worden ten aanzien van ontkenning. Wel is duidelijk dat de mate van depressie een negatief effekt heeft op de toestand van de patient enige tijd na het infarct. Gekombineerd met het veelvuldig voorkomen van depressieve symptomen zou dit leiden tot de konklusie dat vele hartpatiênten een minder rooskleurig vooruitzicht hebben. Dit is in tegenspraak met het exvaringsgegeven dat de toestand van patiënten één of twee jaar na infaxct een aanzienlijke mate van variatie te zien geeft. Men moet dan aannemen 
dat patiênten vooral verschillen in de mate waarin zij de depressie te boven konden komen. Volgens Hackett en Cassem zou de verklaring moeten liggen in de meer of mindere mate van sukses van ontkenning. Dit aspekt van hun model is echter het zwakst onderbouwd met empirische gegevens. Bovendien is het onaannemelijk dat herstel na hartinfarct overwegend te beschrijven en te verklaxen zou zijn met behulp van intidasychische mechanismen.

De gezondheidsperceptie-benadering

De gezondheidsperceptie $1 \mathrm{~s}$ min of meer toevalilig in het onderzoek naar herstel na hartinfarct terecht gekomen met name door toedoen van Gaxity $\left(1973^{\mathrm{a}}, \mathrm{b}\right)$. Deze auteur ging in eerste instantie uit van de $z . g$. aktiviteitsteorie van veroudering (Maddox, 1963). Deze teorie voorspelt een positief verband tusser de mate van sociale aktiviteit en welbevinden bij de verouderende mens. In onderzoek bij hartinfarctpatienten vond Garrity echtex, dat de gezondheidsperceptie, gemeten op een tien-puntsschaal. volgens Cantril, de belangrijkste voorspellex was voor zowel moreel als werkhervatting. Brown en Rawlinson (1975, 1976) vonden voor patienten na een open-haxtoperatie dat de gezondheidsperceptie zowel het moreel, als de geneigdheid de rol van patient af te leggen voorspelde. De voorspellende warde van gezondheidsperceptie bij zowel Garrity als Brown en Rawlinson bleef behouden bij kontrole voor de ernst van de aandoening. Beide onderzoeken zijn transversaal opgezet, wat de wadrde van de bevindingen weer vermindert. Eenzelfde bezwaar kan worden aangevoerd tegen de ondexzoeken wan Cay (1973) en Monteiro (1979), waaxult bleek dat de gepercipleexde handicap, respektievelijk de geschatte ernst van het infarct samenhingen met werkhervatting.

In de genoemde onderzoeken geldt dat het verband tussen gezondheldsperceptie en de afhankelijken als moxeel en werkhervatting mogelijk gekontamineerd was. Er is echter én longitudinaal ondexzoek bekend onder 293 hartinfarctpatisiten warin de mate van vooruitgang op twee manden na infarct, geschat door de patient, van voorspellende betekenis bleek voor werkhervatting. kiachten en het oordeel of het leven weer als normal kon worde beschouwd, dit alles én jaar na infarct (croog en levine, 1977 Het berwar tegen dit onderzoek is dat uitsluitend bivariate analyses zijn toegepast, zodat de relatieve betekenis van de 
voorspeller in kwestie onduidelijk is. In de literatuur over veroudering zijn eveneens longitudinale studies bekend, warin gezondheidsperceptie een voorspellende warde heeft voor levenssatisfaktie (streib, 1956; Maddox et al., 1962; Palmore et a1., 1972).

Het is eigenlijk merkwaardig dat de gezondheidsperceptiebenadering aanvankelijk beperkt is gebleven tot de voorspellende warde van deze faktor voor een aantal outcome-variabelen. Pas later heeft Garrity het gemis gekonstateerd van een konceptueel model warin gezondheidsperceptie en ziektegedrag aan elkaar gekoppeld kunnen worden (Garrity et a1. "1978). In een onderzoek naar de faktoren die de gezondheidsperceptie bij gezonden beinvloeden kwam hij tot twee verklarende variabelen: de Langner-index voor psycho-fysiologische klachten en recente 1 ife-events. Op grond van deze bevindingen zag Garrity de mogelijkheid tot een aansluiting van gezondheidsperceptie bij het life-change-model van Mechanic (1974). Deze benadering gaat ex van uit dat life-events spanningen oproepen die tot psychische malaise en op zichzelf onschuldige klachten kunnen leiden. De psychische malaise kan gemakkelijk leiden tot een definitie van die klachten als ziekte en tot ziektegedrag. Wanneer er eenmal van ziekte sprake is, dat wil zeggen als de gezondheidszorg de klachten van een etiket heeft voorzien, vindt een omkering plates: was de malaise aanleiding tot de ziekte, nu ziet de patiēnt de malaise als gevolg van de ziekte. Naarmate het gevoel van malaise groter is, zal de gezondheidsperceptie negatiever zijn (Garrity, 1978). Toegepast op het herstel na infarct zou dit betekenen dat de gezondheidsperceptie op zijn minst doox twee faktoren beinvloed wordt: ten eerste de ernst van het infarct én de reeds aanwezige psychische malaise ten gevolge van doorgemakte Iife-events. Patienten die voor hun infarct reeds klachten of gevoelens van malaise hadden zullen dan, bij gelijke objektieve ernst, een negatievere gezondheldsperceptie hebben en dus een problematischer herstel te zien geven, dan. patiênten die dat niet hadden. Indirekte steun voor deze verondersteliing $\mathrm{kan}$ worden verschaft door het reeds geciterexde onderzoek van cay et al. (1972) warbij een verband werd gevonden tussen depressie en angst na infarct en spanningen en problemen vór het infarct.

Een soortgelijke bevinding is die van croog en Levine (1977) die een verband vonden tussen ervaren spanningen met betrek- 
$k$ ing tot het werk vor infarct zoals vastgesteld circa twee manden na infarct en depressie een jaar na infarct. Deze steun is indirekt on twee redenen. Allereerst is niet duidelijk of de spanningen en problemen van voor het infarct in relatle staan tot doorgemakte life-events. Het onderzoek van Croog en Levine doet bovendien vermoeden dat het njet zozeer gaat om specifieke gebeurtenissen, dan wel om als chronisch ervaren spanningen. Dit gegeven is niet zonder betekenis als men beseft dat 65 van de onderzoekspopulatie van Croog en Levine spanningen met betrekking tot het werk als etiologische faktor voor het infarct beschouwde. De tweede realen warom deze onderzoeken slechts indirekte steun geven aan Garrity's tese is gelegen in het feit dat gezondheidsperceptie niet als varlabele is opgenomen en men een, overigens niet onaannemelijk, negatief verband moet veronderstellen tussen depressieve symptomen en gezondheidsperceptie. zoals gezegd zou verondersteld moeten worden dat de gezondheidsperceptie behalve doox pre-infarct spanningen en malaise, ook beinvloed wordt door de ernst van het infarct, met andere woorden: de vraag is of de ernst van het infarct samenhangt met de gezondheidsperceptie. Het probleem is dan wel wat men bedoelt met ernst van het infarct. Bedoelt men de door de patiënt gepercipieerde ernst dan is duidelijk dat deze buitengewoon moeilijk te onderschelden zal zijn van de gezondheidsperceptie. Wanneer echter objektieve ernst wordt bedoeld, bijvoorbeeld geschat door de behandelend arts (croog en Levine, 1977; Garrity, 1973 ) of vastgesteld middels een index voox de ernst (Cay et al., 1972; peel-index) of door de grootte van het infarct (Stern et al., 1977; Piek-CPK), dan is het antwoord op de gestelde vraag, dat geen verband bestad tussen objektieve ernst en de opvatting van de patiejt over zijn gezondheid. In de klinische praktijk werden extreme gevallen, warin patienten gehandicapt gedraq vertoonden, dat in geen enkele verhouding stond met de objektieve fysiologische beperkingen, reeds betrekkelijk vroeg gesignaleerd. In het bekende artikel van klein et al. (1965) werd dit verschijnsel aangeduid als cardiac invalidism. op basis van de geciteerde ondexzoeker kan meer in het adgemeen een gebrek aan relatie tussen objektleve ernst en gezondheldsperceptie worden verondersteld.

Ex is vaak verondersteld dat patienten uit de 'lagere" beroepen in het algemeen en minder positieve gezondheidsperceptie 
zullen vertonen dan patienten uit de 'hogere' beroepen, op grond van het feit dat zij meer gewend zijn aan een relatief hoog inspanningsniveau en dus de beperkingen die het infarct oplegt duidelijker zullen ervaren. In de literatuur is geen duidelijke steun hiervoor te vinden. Garrity (1973 $3^{\mathrm{a}}$, b) vinat geen relatie, terwijl croog en Levine (1977) er geen melding van maken. Laatstgenoemde auteurs vermelden wel uitvoerig dat, zodra de gezonaheidsperceptie in relatie tot het werk wordt gebracht, zoals de verwachting weer aan het werk te kunnen. wel heel duidelijke verschillen in de verwachte richting tussen lage en hoge beroepen ontstaan. Monteiro (1979) vond dat cardiac invalidism meer voorkomt onder hand- dan onder hoofdarbeiders.

Tenslotte kan men zich afvragen of de gezondheidsperceptie een verband vertoont met de algemeen psychologische 'make-up' van de patiënten. Het was Josten (1970) opgevallen dat de scores van hartinfarctpatiënten op de neuroticismeschaal en in mindere mate op de extraversieschaal een bi-modale verdeling vertonen. op basis hiervan verdeelde hij zijn onderzoeksgroep in drie groepen: patiënten met een neuroticismescore onder de mediaan en een extraversiescore boven de mediaan, een groep met de tegenovergestelde eigenschappen en een tussengroep. De extraverte, laag neurotische groep, blijkt dan verreweg de meest optimistische toekomstverwachting te hebben en zich bovendien weinig lichamelijk belast te voelen in het dagelijks leven. De neuratische, laag extraverte groep, is pessimistisch over de toekomst en voelt zich ernstig belast in het dagelijks leven. De tussengroep neemt in bijna alle opzichten een midaenpositie in. In efn opzicht wijkt deze groep af van belde andere: er komen veel en ernstige angineuze klachten in voor. Als men bereid is toekomstverwachting als een indikator van gezondheldsperceptie op te vatten, dan wettigt het onderzoek van Josten de veronderstelling dat gezondheidsperceptie samenhangt met basale psycholgische dimensies als neuroticisme en extraversie. Josten legde in zijn onderzoek geen vexband met pre-infarct persoonlijkheidskenmexken, zodat onduidelijk is of sprake is van konstante persoonlijkheidskenmerken, dan wel van een reaktiepatroon op het hartinfarct. 
KONKLUSIES

In het 1 iteratuuxoverzicht is gezondheidsperceptie op verschillende manieren opgevat. Lang niet alle auteurs presenteren toekomstjerwachting, geschatte ernst van het infarct, mate van het zich gehandicapt voelen, onder het hoofd gezondheldsperceptie. Gezien de begripsmatige verwantschap lijkt behandeling van al deze variabelen onder een noemer toch wel gerechtvaardigd. Hoewel dus te betwijfelen valt of de gezondheidsperceptie-benadering als een volwaardige, op zichzelf staande invalshoek kan worden beschouwd, zoals Krantz (1980) doet, valt in het literatuuroverzicht de voorspellende waarde van de variabele gezondheidsperceptie op voor verschillende outcome-indikatoren als werkhervatting en algemeen welbewinden. Er is enige reden om an te nemen dat de gezondheidsperceptie na infarct beinvloed wordt door ervaren spanningen voor het infarct. of deze spanningen al of niet in verband staan met doorgemakte Iife-events is minder duidelijk.

In het algemeen wordt verder gevonden dat weinig verband bestaat tussen de objektieve ernst van het infarkt en gezondheidsperceptie. Deze bevinding komt overeen met die ten aanzien van de relatie tussen ernst en emotionele problemen. Hierbij kan worden opgemerkt dat het niet aannemelijk is dat de ernst van het infarct direkt van invloed is op de gezondheidsperceptie. Wel kan men zich voorstellen dat een ernstig infarct bijvoorbeeld leidt tot klachten bij geringe fysieke inspanning en langs deze weg de gezondheidsperceptie beinvloedt. Er is echter een groot aantal andere faktoren warvan kan worden verondersteld dat $z i j$ de gezondheidsperceptie zullen beinvloeden, zoals de kommunikatie tussen arts en patient, verwachte zlektewinst en de reële verwachting niet meer te kunnen terugkeren naax zwar werk.

Terislotte kan worden verondersteld dat de gezondheidsperceptie gerelateera is an basale psychologische dimensies als newroticisme en extraversie. Hoog extraverte en laag neurotische patiënten zulien een positieve inschatting laten zien, terwijl laag extraverte, hoog neurotische patienten pessimistischer zullem zijo.

\section{De patientenloopbaan-benadering}

Het ldee on het koncept loopbaan toe te passen buiten de beroepssfeer is zowel uitgewerkt voor afwijkend gedrag (Goffman, 1961; Lemext, 1967) als voor ziektegedrag bij aandoeningen als 
tuberculase (Roth, 1963) en poliomyelitis (Davis, 1961). Genoemde auteurs werken het idee nogal verschillond uit. Dit is het beste te illustreren aan de tegensteling RothLemert. Zo spreekt Roth van een loopbaan, wanneer een aantal opeenvolgende stadia worden doorlopen in een gegeven richting en met een duidelijk einddoel, terwijl Lemert de onzekerheden en problemen die gepaard gaan met een loopbaan centraal stelt. De wijze warop met die onzekerheden wordt omgegaan is dan het kenmerk van die loopbaan. In feite is er dus geen sprake van een echte tegensteliing, bij Roth staat de strukturele kant voorop, bij Lemert de proceskant. Finlayson en McEwen (1977), die de patientenloopbaan introduceerden voor de beschrijuing van herstel na hartinfarct, vullen deze verder aan met rolteoretische noties als roltransitie en herordening van rollen. Monteiro (1979) makt impliciet gebruik van het loopbaan-koncept en vult dit aan met klassieke ziektegedrag-benaderingen (Parsons, 1951; Suchman, 1965; Philipsen, 1969). Ziektegedrag wordt hierin beschreven aan de hand van een antal beslissingsmomenten, lopend van het ervaren van onwelbevinden tot en met het afleggen van de rol van patiênt. Het is zeker aantrekkelijk aan te sluiten bij een standaardmodel van de medische sociologie, temeer daar begrippen als loopbaan en roltransitie hiermee zeer wel verenigbaar zijn.

Een direkte beschrijving van het herstel na hartinfarct met stadia in termen van rollen en zelfbeelden vindt men bij Idelson et al. (1974). In dit diepte-onderzoek werden elf mannen en hun partners gedurende een jaar na infarct vif mal geinterviewd. Tijdens de opname in het ziekenhuis is overduidelijk sprake van de rol van patient met als zej. beeld dat van de kwetsbare overlever. Een maand na ontslag ziet de patient zich als herstellend. Enkele maanden daarna treedt onzekerheid en verwarring op over de te vervullen rollen. Vier manden verder vindt een geleidelijke terugkeer naar het 'normale' leven plaats, met dien verstande dat de ziekte geintegreerd is in het zelfbeeld. Men moet zich overigens realiseren dat de precieze tijaschaal ult het onderzoek van Idelson bepald wexd doox de momenten van de interviews en de specifieke onderzoeksgroep. Dit wil zeggen dat de diverse stadia in elk geval kunstimatig kunnen zijn en zich in een ander tempo kummen voltrekken. Niettemin toont de beschrijuing van Idelson aan dat de gangbare zlektegedrag- 
modellen te kort schieten in de meer gedetailleerde beschrijving van substadia en processen die voorafgaan aan de mogelijke aflegging van de rol van patient. Howel gesteld is dat de tijdschal uit het onderzoek van Idelson niet matgevend hoeft te $z 1 j n$, bevestigt het onderzoek van Finlayson en McEwen (1977) onder 76 mannen na eerste infarct wel de gevestigde indruk. In dit Engelse onderzoek bleek ontslag ult het ziekenhuls door de patienten min of meer beschouwd te worden als aflegging van de patientenrol, daar zij met redelijk optimisme huiswarts keerden. Dit optimisme werd in het algemeen weer teniet gedaan, doordat de patienten nu gekonfironteerd werden met lichamelijke beperkingen, de toepassing van medische voorschriften en de overbezorgdheid van de partner. Er trad een soort regressie naar de rol van patiënt op, gepaard gaande met depressieve symptomen. Men ziet hier overigens de overeenkomst met de homecoming depression van Hackett en Cassem. Na deze fase begint een geleidelijk herstel van circa vier à zes maanden dat gekenmerkt wordt door onzekerheid over te vervulien rollen en het uitproberen van nieuwe recipes for action. Een half jaar na infarct is nog steeds sprake van verminderde fysieke en sociale aktiviteit.

Einlayson en McEwen wijzen erop dat herstel een konfijkt impliceert. Enerzijas wordt de patiënt geacht te herstellen, dat wil zeggen terug te keren naar een zo normal mogelijke levensstijl, anderzijas wordt dit door voorschriften en overbezorgdheid gefnuikt, ex is met andere woorden sprake van een afhankelijkeheids - onafhankelijkheidskonflikt. Monteiro (1979) gat dit probleen te 1 ijf met het role strain-model van Goode (1960). Hierin wordt het afleggen van de $r o l$ wan patient verklaard vanuit de mate van binding met de 'normale' rollen warnaar iemand terugkeert, zijn inschatting van mogelijk negatieve gevolgen van de terugkeer en de rolverwachtingen van signifikante anderen. In hav transversale onderzoek bjj 118 hartinfarctpatiènten werk Monteiro dit als volgt uit.

Het afleggen van de roll van patiënt en de terugkeer nar een "normale" rol werd opgevat als werkhervatting, terwijl de negatieve gevolgen werden geindiceerd middels de gepercipleerde dreiging van een re-infarct. Het role strainmodel voorspelt dan dat in konfliktsituaties, dat wil zeggen situaties warin zowel de binding aan de rol als de geschatte dreiging belde sterk of beide gering zijn, de 
rolverwachtingen van de signifikante anderen de doorslag zullen geven bij het al dan niet terugkeren naar werk. Wanneer de verwachtingen in de richting van hervatting liggen volgt werkhervatting, in de omgekeerde situatie volgt geen werkhervatting. Bij een gering geschatte dreiging en een sterke binding doen de signifikante anderen niet zo terzake en wordt werkhervatting voorspeld. In het omgekeerde geval, sterke dreiging, gexinge binding aan arbeidsrol, vindt, ongeacht de verwachtingen van anderen, geen hervatting plats. Het model blijkt redelijk op te gaan voor handarbeiders. Bij hoofdarbeiders wordt überhaupt meer werk hervat, zodat de indruk gevestigd wordt dat beroepsniveau een belangrijkere voorspeller is voor werkhervatting dan de variabelen van het role strain-model. Er was overigens geen verband tussen beroep en geschatte dreiging.

\section{KONKLUS IES}

De patiëntenloopbaan-benadering beschrijft herstel in termen van de gangbare ziektegedrag-modellen, met dien verstande dat belangrijke aanvullingen worden aangebracht in de fase die ligt tussen het verkeren in de rol van patiënt en de aflegging ervan. Uit het geciteerde onderzoek is gebleken dat van een geleidelifke overgang sprake is die gepaard gaat met onzekerheden, geruime tijd kan duren en een inherent afhankelijkheidskonflikt in zich draagt. In termen van rolgedrag is deze fase aan te duiden als een kwetsbare: er is niet meer sprake van de duidelijk gedefinieerde patiëntenrol en nog niet van een terugkeer naar oude rollen of het aannemen van nieuwe rollen. In principe zijn er twee mogelijke uitkomsten, of er volgt een bestendiging van of een terugval naar de rol van patient, of er volgt een gehele of gedeeltelijke aflegging van de rol van patiênt.

\section{3 Hexstel nader bezien}

De beslissing herstel na hartinfarct in eerste instantie te beschrijven met behulp van de drie onderscheiden benaderingen is gebaseerd op een empirische indeling van de literatuur op dit gebled. Uit teoretisch oogpunt heeft dit bijgevolg lets arbitrairs. Men ziet dan ook dat de benaderingen in elkar overlopen en elkaar lijken aan te vullen. Een beschouwing over 
vorschillen en overeenkomsten tussen de benaderingen kan behulpzaam zijn voor een nadere precisering van het begrip herstel.

On te beginnen moet worden opgemerkt dat alle benaderingen zich richten op psycho-social herstel en zich weinig gelegen laten 1iggen aan fysiek herstel. Met uitzondering wan de gezondheidsperceptie-benadering, leggen beide andere de naaruk op herstel als proces. De gezondheidsperceptie-benadering geeft eigenlijk alleen max aan dat de inschatting van de gezonaheld door de patient van betekenis is voor het verklaren van verschillen in bepalde eindtoestanden.

Het problem van alle arie benaderingen is het ontbreken van een omschrijving van wat nu eigenlijk onder herstel moet worden verstaan. Impliciet wordt onder herstel respektievelijk verstaan: het overwinnen van de depressie, het komen tot een positievere gezondheidsperceptie en het afleggen van de patientenrol. In elk geval valt de impliciete notie van herstel niet noodzakelijkerwijs samen met die van het aagelijks lewen: herstel is het weer in oude staat terugbrengen van iets wat op een of andere manier in het ongerede is geraakt. Men zou echter redelijk staande kunnen houden dat herstel een verbetering inhoudt van een oorspronkelijk ongunstige situatie. Zo zou fysiek herstel o.a. kunnen worden opgevat als een verbetering in de lichamelijke konditie vanuit een beginsituatie die op een of andere maniex als ongunstig is beoordeeld. Gelijksoortige voorbeelden kunnen worden uitgewerkt voor psychisch en sociaal herstel. Een definitie vam herstel zou dus kortweg kunnen luiden:

Herstel van een ziekte is de overgang van een als ongunstig nar een als gunstig beoordeelde toestand.

Deze onschrijving gat uit van de gedachte dat herstel een kwestie van beoordeling is. Een implicatie hiervan is dat er versehillende oordelen op verschiliende gronden gegeven kunnen worden en dus verschil van mening kan bestaan over de vraag of al dan niet sprake is van herstel.

Ex zin drie bronnen van beoordelingen te onderscheiden. Allereerst kan een oordeel geveld worden door professionele hulpverleners: het deskundigenoordeel. Daarnaast zullen de patient en zijn omgeving zich eveneens een oordeel vormen: het betrokkenenoordeel. Tenslotte kan een matschappelijk aanvard oriterium ontrent herstel bestaan: het matschappe- 


\section{lijk oordeel.}

Het deskundigenoordeel zal in het algemeen gebaseerd zijn op een objektieve maat of meting, bij voorbeeld inspanningstolerantie, elektrocardiografische afwijkingen, bloeddruk e.d. Herstel dat door deskundigen, vooral op grond van dit soort metingen wordt vastgesteld, zal hier verder worden aangeduid als objektief herstel. Het betrokkenenoordeel zal in het algemeen gebaseerd $z i j n$ op gevoelens van (on)welbevinden, ervaren problemen in het leven van alledag, waardering van aktiviteiten e.d.. Herstel dat op grond hiervan wordt vastgesteld zal verder subjektief herstel worden genoemd. Het meest duidelijke voorbeeld op grond waarvan een matschappelijk oordeel over herstel wordt uitgesproken, is wel werkhervatting. vanuit de patiënt gezien is dit oordeel echter een objektief gegeven, zodat aok werkhervatting kan worden opgevat als objektief herstel. Voor zover de patiënt op grond van werkhervatting over zijn herstel oordeelt, duidt dit criterium echter weer op subjektief herstel. Het is dus mogelijk op grond van het onderscheid tussen matschappelijk, deskundigen- en betrokkenenoordeel, dat hetzelfde criterium voor objektief en subjektief herstel kan worden benut.

Met behulp van het hier ontwikkelde onderscheid objektief subjektief herstel kan nu meer in detail worden ingegaan op de resultaten van onderzoek betreffende de drie inhoudelijke deelgebieden van herstel, te weten fysiek, psychisch en sociaal herstel.

\subsection{Drie aspekten van herstel na hartinfarct}

\section{Fysiek herstel}

De termen fysiek, psychisch en sociaal herstel hebben op zichzelf nog een globaal karakter en kunnen derhalve op verschil w lende maniexen, zowel naar aard als naar mate van specificttelt, worden uitgewerkt.

Bij objektlef fysiek herstel is men snel geneigd te denken in termen van een verbetering van de lichamelijke fitheid of lichamelijke konditie. Het deskundigenoordeel zal veelal uitgaan van een inspanningsfysiologische benadering van dit onderwerp, die echter grotendeels buiten het bestek van alt betoog valt. We beperken ons hier tot lichamelijke konditie opgevat als maximaal prestatievermogen of maximale inspanningstolerantie gemeten als de maximale zuurstofopname of de maximale 
uitwendige belasting. Het is niet onredelijk te veronderstellen dat korte tuja na infarct de maximale inspanningstolerantie, gemiddeld genomen, verlaagd zal zijn. Bij het zoeken nate empixische steun voor deze veronderstelling doen zich op zijn minst drie problemen voor. Ten eerste moet men er rekening mee houden dat de verminderde 1 ichamelijke konditie - nast de ernst van de beschadiging van het hart-mede beinvloed wordt door de duur van de bedrust (wenger, 1979).

vervolgens is men pas enkele jaren geleden begonnen met vroeg. dat wil zeggen twee a arie weken na infarct, inspanningsonderzoek (bv. DeBusk, 1978). Uit die onderzoeken blijkt niet, dool het ontbreken van een verwijzing naar een norm en omdat alleer submaximal belast werd, in hoeverre sprake is van een vermin derde inspanningstolerantie. Tenslotte moet men voor longitudinale gegevens vak teruggrijpen op de resultaten van kontrolegroepen in trials naar het effekt van fysieke training op het prestatievermogen na infarct.

Het eerste inspanningsonderzoek in deze trials is op zijn vroegst zes weken na infarct. Het is al met al moeilijk een soort 'natuurlijk verloop' in de lichamelijke konditie na infarct te rekonstrueren.

Wel is bekend dat in groepen infarctpatiënten met een ongekompliceerd verloop, die een gemengd karakter hebben ten aanzien van het interval infarct-inspanningsonderzoek, het gemiddelde prestatievermogen 10 à $20 \%$ beneden de standaardwaarde ligt (weeda, 1969; standaardwaarden voor Nederland, zie Weeda et al. , 1975). Het prestatievermogen van patiënten met coronaire insufficientie is gemiddeld $30 \%$ lager dan de standarawarde (Weeda, 1971).

Uitgaande van de trials van Helsinki (Kentala, 1972), Götenborg (wilhelmsen, sanne et al., 1975) en het onderzoek vam Kellerman en Kariv (1968), zou gesteld kunnen worden dat de maximale inspanningstolerantie van hartinfarctpatienten twee a drie manden na infarct 40 tot 50 \% lager 1 igt dan de warare van gezonde mensen uit dezelfde leeftijascategorie. De verbetering in lichamelijk prestatievermogen bij niet getrainde patiënten tussen twee en twalf maanden na infarct ligt volgens de twee genoemde trials in de orde van groote van 10 aे $20 \%$.

In vergelijking met de cijfers van weeda (1969, 1971) die zijn gebaseerd op patiëntengroepen met ongelijke intervallen infarct-inspanningsonderzoek, 1igt het prestatievermogen in de genoemde onderzaeken dus nogal aan de lage kant. 
Dit kan veroorzaakt worden door verschillen in de karakteristieken van de patiëntengroepen en aan verschilien in het protocol van het inspanningsonderzoek. Op basis van beschikbare gegevens kan men hierover slechts vermoedens uiten. Het onbevredigende resultaat van een en ander is dat het lichamelijke prestatievermogen van hartinfarctpatiënten verlaagd is (orde van grootte?) en dat vermoedelijk een zeker herstel optreedt (orde van grootte?) in het eerste jaar na infaret.

Het 1 ichamelijk prestatievermogen na infarct wordt in hoofdzaak bepaald door de ernst van het infarct (pompfunktiestoornissen, angina pectoris e.d.), het prestatievermogen van vór het infarct en ook wel door de duur van de ziekenhuisopname (bijvoorbeeld Kentala, 1972; Clausen, 1976). Kentala's stapsgewijze regressie-analyse verschaft bovendien inzicht in de determinanten van het prestatievermogen én jaar na infarct. Deze wordt in hoofdzaak bepaald door het prestatievermogen op twee maanden na infarct en de mate van fysieke aktiviteit tussen twee en twaalf maanden na infarct.

Een tweede benadering wan het objektief fysieke herstel kan gebaseerd worden op het verloop van $k l$ achten die betrekking hebben op het dysfunktioneren van het cardiale systeem als pijn op de borst en kortademigheid. Helaas stuit men ook hier op een gebrek aan adekwate gegevens. In het onderzoek van Mayou et a1. $\left(1978^{\mathrm{a}},{ }^{b}\right)$ onder 100 hartinfarctpatiënten -waaronder 11 vrouwelijke (mannen en vrouwen worden niet afzonderlijk geanalyseerd) - rapporteerde twee manden na infarct circa $65 \%$ én of beide van bovengenoemde klachten. Eén jaar na infarct was dat percentage urijwel gelijk. In hoeverre dit dezelfale patiënten betrof, wordt niet vermeld. Finlayson en McEwen (1977) vonden in hun onderzoek onder 78 mannelijke infarctpatiënten dat het percentage patieñten met pijn op de borst op drie en zes maanden na infarct, gelijk is; namelijk 51 . Ook hier zijn de veranderingen niet vermeld. Kentala (1972) vermeldt deze klachten alleen van vóór en van 12 maanden na het infarct. Op het laatstgenoemde tijdstip werd bij 59: van de patienten uit de kontrolegroep $(n=73)$ angina pectorls en bij $45 \%$ dyspnoe vastgesteld. Bij het fenomeen klachten moet men altijd voor ogen houden dat er sprake is van een indirekte relatie met het orgaansysteem waarop die klachten betrekking hebben. Psychische en sociale faktoren zullen hoogstwarschijnlijk interveniêren. 
Zo vond Mayou (1978 ${ }^{a}$ ) dat klachten als pijn op de borst en kortademigheid samenhingen met depressieve symptomen. Ook $1 \mathrm{~s}$ een onderzoek bekend (Bakker en Levenson, 1967) waaruit blifkt dat bij lagere beroepen meer angina pectoris wordt vastgesteld.

De voorzichtige konklusie moet dan zijn dat een niet onaanzienlijk deel van de patiënten gedurende enige tijd na infarct symptomen rapporteert die in verband kunnen staan met de toestand van het cardiale systeem, maar dat over het verloop van de klachten alleen valt te veronderstellen dat geen dramatische toe- of afname optreedt.

Het verloop in de fysieke aktiviteiten na infarct is een derde manier om het fysieke herstel te operationaliseren. Hier kan meteen bij vermeld worden dat over de objektleve benadering hiervan nagenoeg niets bekend is. Het belangxijkste probleem lijkt te zijn gelegen in de bewerkelijkheid van de metoden om de mate van fysieke aktiviteit in het dagelijks leven vast te stellen (Lange-Andersen, 1978). De enquete-metade is met name ook in Nederland ontwikkeld doox Van der Sluijs (1972) en onder andere toegepast in de Helsinki-trial van Kentala. Deze auteur gebruikt echter het gehele weekend plus én werkdag als uitgangspunt om de fysieke aktiviteiten vast te leggen. Dit levert een duidelijke overwaardering van de vrije tija en bijgevolg erg lage warden voor de mate van fysieke aktiviteit op.

Ex zijn wel een antal onderzoeken die informatie geven over de subjektjeve variant van fysiek herstel in termen van fysieke aktiviteiten. Op een bepala tijastip na infarct woxdt de patienten gevraaga hoe aktief ze zichzelf achten en dit te vergelijken met de mate van aktiviteit voór infarct. De gegevens worden in het algemeen inadekwat gepresenteera. Zo vermelat Mayou $\left(1978^{\mathrm{a}}\right)$ alleen die gegevens met betrekking tot de situatie twee manden na infarct, hoewel ze de patienten én jaar na infarct nogmals interviewde. Op het genoemde tijdstip meldde 39 van de patienten een middelmatig tot aanzienlijke mate van fysieke aktiviteit. Echter, $90 \%$ van alle patienten beoordeelde het niveau als lager dan voór het infarct. Finlayson en McEwen (1977) melden alleen dat zes maanden va infarct $41 \%$ minder aktief was dan vóór infarct, $16 \%$ 
gelijk bleef en al aktief was, $28 \%$ gelijk bleef en al weinig deed en dat 15 : van de patienten van mening was aktiever te zijn dan woór het infarct. Croog en Levine (1977) noemen alleen het gegeven dat én jaar na infarct 73 van de patienten zichzelf minder aktief acht dan vóor het infarct. Genoemde auteurs vermelden positieve relaties tussen beroep, optimisme van de arts over herstel enerzijds en de instandhouding van het aktiviteitenniveau van voor het infarct op het tijdstip één jaar na infarct anderzijds.

In een retrospektief Engels onderzoek (Mallaghan en Pemberton, 1977) had één tot anderhalf jaar na infarct 60\% van de mannelijke patienten zijn aktiviteiten verminderd, 5 vermeerderd, terwijl 35\% gelijk was gebleven. In dit onderzoek werd gevonden dat degenen die hun aktiviteitenniveau als vexhoogd of verlaagd zagen, hogere neuroticisme-scores hadden dan de gelijkblijvers.

De resultaten uit genoemde onderzoeken laten zich, wederom, moeilijk beoordelen. Om te beginnen is de relatie tussen beginniveau en verandexing in aktiviteiten óf niet gegeven, of niet interpreteerbaar. Vervolgens wordt in geen der genoemde onderzoeken aandacht besteed aan werkhervatting en het oordeel van de patiënt over zijn aktiviteitenniveau. Globaal gesproken verkrijgt men de indruk dat gedurende langere tijd na infarct het aktiviteitenniveau lager zal zijn dan ervoor.

\section{Psychisch herstel}

In de beschrijving wan de psychodynamische benadering Is vermeld dat depressieve symptomen nogal vaak optreden na het hartinfarct. Het ligt daarom voor de hand psychisch herstel op te vatten als een vermindering van deze symptomen. Aangezien depressie wordt vastgesteld aan de hand van een of andere objektieve metode, bijvoorbeeld een psychologische test of een observatie, kan worden gesproken van een objektieve benadering van psychisch herstel. Om te beginnen kan worden vastgesteld dat depressleve symptomen onder herstellende hartinfarctpatienten frekwenter voorkomen dan onder gezonde vergelijkingsgroepen en dat deze zeker enkele maanden kunnen blijwen bestaan (Doehrman, 1977). In twee onderzoeken met mannelijke en 
vrouwelijke patienten met een systematische follow-up van de patienten valt in éen ervan (Mayou, 1978 ${ }^{\mathrm{a}}$, b) op, dat tussen twee en twalif maanden, het percentage patiënten dat als depressief werd beschouwd nawwelijks verandert.

In dit onderzoek werd een semi-gestruktureerd interview gebruikt, warbij de antwoorden achteraf door verschillende beoordelaars werden beoordeeld op de mate van depressiviteit. In het tweede onderzoek (Stern et al., 1976, 1977) waarin de Zung-depressieschaal wera gebruikt, ziet men een geleidelijke daling van het aantal depressieve patiënten. In een ander onderzoek (Skelton en Dominian, 1973) beoordeelde de echtgenote als betrokkene de psychische toestand van de man. Drie maanden na infarct vond bijna de helft van de echtgenotes van de onderzoeksgroep van 65 echtparen dat hun mannen zich afhankelijk opstelden en makkelijk geirriteerd waren. Een jaar na infarct was dat aantal nauwelijks gedaald. Ten aanzien van het verloop van depressieve symptomen is geen eenduidig beeld te konstrueren. De weinige longitudinale onderzoeken lopen te zeer uiteen op het punt van de samenstelling van de patiëntengroepen en vooral op de metoden om depressieve symptomen vast te stellen.

Croog en Levine (1977) lieten de patiënten in hun onderzoek op twee en twaalf maanden na infarct aangeven in welke mate zij 22 persoonskenmerken op zichzelf van toepassing achtten. per saldo bleken de patiënten te veranderen in positieve richting voor kenmerken als plichtsbesef en hard-driving; en in negatieve richting voor jaloezie en egoisme. Voor de andere kenmerken $z i j n$ er of geen auidelijke veranderingen of blifken nagenoeg evenveel patienten in positieve als in negatieve richting te veranderen.

Deze subjektieve benadering van psychisch herstel laat zich niet makkelijk interpreteren. Het is immers mogelijk de gekonstateerde veranderingen op te vatten als veranderingen in sociaal wenselijke richting.

over de faktoren die het psychisch herstel beinvioeden bestaat niet veed duidelijkheid. De ernst van het infarct lijkt -op basis van sommige onderzoeken- op lange termijn gezien weinig invloed te hebben (Cay et a1., 1972; Garrity, $1973^{2}$; stern et a1., 1976, 1977; Doehrman, 1977). In het onderzoek van Croog en Levine (1977) bleek echter een heropname tijdens de herstelperiode van beslissende betekenis voor de outcome na éten jaar; ongeveer $19 \%$ van hun onderzoeks- 
groep werd tijdens het jaar na infarct heropgenomen, $13 \%$ om cardiale redenen. De heropgenomen patienten hadden een slechter subjektief psychisch herstel dan de overige patienten. Het is echter niet duidelijk wat de precieze relatie is tussen heropname en de ernst van het infarct. Uit alle genoemde onderzoeken komt nar voren dat patienten die een à twee manden na infarct pessimistisch waren of depressieve symptomen vertoonden een ongunstige prognose hebben wat betreft hun psychische en sociale outcome na fén jaar.

De bevindingen ten aanzien van de relatie tussen sociale klasse en psychisch herstel zijn eveneens niet eenduidig. Een aantal van de onderzoeken werd al vermeld bij de psychodynamische benadering. Wanneer we wederom het onderzoek van Croog en Levine als een soort toetssteen gebruiken, het is tenslotte het enige longitudinale onderzoek van enige omvang op dit gebied, verkrijgen we het volgende beeld. Gevoelens van moedeloosheid een jaar na infarct hangen samen met de gepercipieerde spanningen in het werk en de mate warin het werk vớr infarct tilarbeid vereiste. Beide faktoren hangen samen met het beroep van de patiënt: in lagere beroepen werden meer spanningen gexapporteerd en werd vanzelfsprekend meer tilarbeid verricht. Indirekt valt hieruit af te leiden dat een lagere soclaal-ekonomische status het psychisch herstel negatief kan beinvloeden.

Sociaal herstel

Het Iijkt vanzelfsprekend dat korte tijd na infarct, evenals het geval was voor fysieke aktiviteiten, de sociale aktiviteiten verminderd zullen zijn. Sociaal herstel kan dan worden opgevat als een uitbreiding van de aanvankelijk verminderde sociale aktiviteiten in gezin, vrije tijd en werk. De patient keert in eerste instantie terug in het gezin in de rol van patiënt. De vraag die bij de gehuwde of, in het algemeen, de in een primaire groep levende patiênt gesteld kan worden luidt, of sprake is van verminderde aktiviteiten die in verband staan met de rol van echtgenoot, c.q. partner. Een primaire sociale aktiviteit is de seksuele ongang. Informatie hieromtrent werd vijwel uitsluitend verkregen over gehuwde mannen via hun vrouw. Het blijkt dat in het algemeen nog maar weinig mannen kort na infarct (cixca twee maanden) seksuele omgang met hun vrouw hebben. 
Na een jaar hebben de meeste mannen deze aktiviteit weer hervat (Skelton en Dominian, 1973; Stern et al., 1976; Mayou et al. $\left.1978^{\circ}\right)$. Daarbij moet worden opgemerkt dat het patroon van de seksuele omgang van voor het infarct van invloed is op het verloop na infarct. zo meldden de vrouwen in het onderzoek van skelton en Dominian dat de frekwentie van de seksuele kontakten vór het infarct al aan het dalen was en dat het infarct deze trend versneld had. Met andere woorden, het mag dan zo zijn dat het merendeel van de patiënten de seksuele aktiviteiten hervat, de frekwentie ervan zal in het algemeen verminderen.

Een tweede aspekt dat bij de bestudering van sociaal herstel betrokken kan worden is dat van de participatie van de man in het huishouden. Blijkens het onderzoek op dit gebied, waarbij overigens nooit direkt het takenpakket werd onderzocht, vindt een overdracht van taken plaats van de man aan de vrouw, een overdracht die van blijvende aard is. Finlayson en McEwen (1977) melden dat $61 \%$ van de vrouwen één jaar na infarct een definitieve overname van huishoudelijke taken rapporteert. Dit verschijnsel deed zich het sterkst voor bij patiënten uit de hogere beroepen. Croog en Levine (1977) vonden dat één jaar na infarct bijna driekwart van de patiënten zichzelf minder aktief in het huishouden achtte dan vóór het infarct. De genoemde onderzoeken zijn overigens de enige in hun soort die min of meer systematisch aandacht besteden aan huishoudelijke aktiviteiten. De indruk die men overhoudt is dat zich na infarct belangrijke, blijvende wijzigingen voordoen in het takenpakket van de man. Het probleem dat zich bij de beoordeling van deze resultaten voordoet is dat geen rekening is gehouden met andere aktiviteiten, met name werkhervatting wordt pijnlijk gemist in de analyse.

Wat betreft de aktiviteiten in de vrije tijd kunnen we alleen nog terugvallen op het onderzoek van Finlayson en MCEwen. In dit onderzoek bleken de vrijetijdsaktiviteiten over het geheel genomen drastisch te verminderen, zelfs over een periode van viex jaar na infarct, dit alles naar oordeel van de patiënt. Belangrijk hierbij is dat de vermindering in deze aktiviteiten èn algemene trend is die voor zowel de werkhervatters als de niet-hervatters opgaat. 
Over de faktoren die het sociaal herstel in gezins-en vxijetijasaktiviteiten beinvloeden is verrassend weinig bekend. Men zou toch moeten aannemen dat de vrouw een belangrijke invloed kan uitoefenen op met mame de aktiviteiten van de man in het gezin. De onderzoeken van Finlayson en MoEwen (1977), Croog en Levine (1977) en Mayou (1978 ) melden allen dat de vrouw vaak een overbezorgde houding aanneemt ten aanzien van haar man. Wat de invloed van die houding is valt niet direkt uit de genoemde literatuur te lezen. Een aanknopingspunt is de relatie tussen de sociale klasse en de overname van huishoudelijke taken, zoals vermeld door Finlayson en McEwen. In de lagere sociale klassen vindt rellatief weinig overname van taken door de vrouw plaats en er is bovendien sprake van een geringe kommunikatie over de problemen van het infarct voor het huishouden. Deze verschijnselen zijn in overeenstemming met de bevindingen uit gezinssociologische onderzoeken, dat in lagere saciale klassen het traditionele huwelijk met geschelden taken en weinig kommunikatie overwegend aanwezig is, terwijl in de hogere klassen het kameraadschappelijke huwelijk met een diffuse taakverdeling en veel kommunikatie het dominerend type is (Young en Willmott, 1975). Met andere woorden, de reaktie van de vrouw op het infarct van de man zal in eerste instantie bezien moeten worden vanuit meex algemene gezinssociologische gezichtspunten.

Het grootste deel van het onderzoek over herstel na infarct concentreert zich op werkhervatting. Werkhervatting is niet alleen de duidelijkste manifestatie van soclaal herstel -de rol van patient is afgelegd, een centrale positierol is weer opgenomen-maar wordt ook geacht fyslek en psychisch herstel te impliceren (Safilios-Rothschild, 1970).

Het onderzoek naar werkhervatting na infarct heeft een enorme stimulans gekregen in de tweede wereldoorlog. In de artikelen die in en vlak na deze periode verschenen wordt overigens geen onderscheid gemakt tussen de verschillende cardiale aandoeningen. Het was er vooral on te doen aan te tonen dat een niet onaanzienlijk deel van de hartpatienten kon werken en een acceptabel ziekteverzuim-patroon vertoonde. om de geschiktheid voor de terugkeer naar het werk te evalueren ontstonden de zogenaamde work classification units (WCU"s). Het eerste grote onderzoek uit de unit van het 
Bellevue Zlekenhuis in New York van Kresky en Goldwater (1944) meldde dat 47\% van de ruim 1000 mannelijke hartpatiennten normaal werkte. Een tweede onderzoek van de staf van dezelfde unit (1951) komt tot een percentage van 45. Het ziekteverzuim van de werkende hartpatienten bleek in dit onderzoek niet af te wijken van landelijke cijfers. Vanaf 1960 werd meer in het bijzonder aandacht besteed aan de werkhervatting van hartinfarctpatienten. Daarbij werd in hoofdzaak geanalyseera op twee variabelen: het percentage hervatters en de snelheia van hervatting. Hiet zal geen verwondering wekken dat het percentage hervatters nogal wat variatie laat zien, afhankelijk van de samenstelling van de onderzochte groep. Een algemene trend is echter dat het percentage hervatters in de Angelsaksische landen hoog is in vergelijking met andere landen. In het overzichtsartikel van Doehrman (1977) wordt op basis van een tiental artikelen uit het Angelsaksisch taalgebied geschat dat circa $85 \%$ van de overlevenden één jaar na het infarct het werk heeft hervat. Nederlands onderzoek geeft meestal lagere cijfers te zien, zij varieren van 56 tot 71\% (Oostenbrink, 1971; Lie et a1., 1975; Visser, 1977; vermeulen et al. , 1978; Erdman, 1979). Schattenderwijs zou men voor Nederland uitkomen op een hervattingspercentage van circa 60\%. Westduitse en scandinavische cijfers liggen in het algemeen enkele procenten hoger dan de Nederlandse (Kühns et a1., 1978; Matzdorff, 1978; Kjøller, 1976; Wilhelmson, 1976). Nu kan men aan deze verschillen allerlei betekenissen gaan toekennen, bij voorbeeld in termen van verschilien in de sociale verzekeringen in de diverse landen. Het enige wat ons inziens uit deze op lokale onderzoeken gebaseerde cijfers mag worden gekonkludeerd, is, dat men een betrekkelijke warde moet toekennen aan de absolute hoogte van het hervattingspercentage. Op het punt van het interval hartinfarct-werkhervating is er een stexke overeenkomst tussen bijna alle onderzoeken: het grootste deel (rond de 80 \% van het antal dat uiteindelijk het werk hervat) van de hervatting vindt plaats in het eerste half jaar na infarct.

In tabel. 1 zijn twalif onderzoeken bijeengebracht die een totaalindruk geven van respektievelijk de hoogte van het hervattingspercentage en de faktoren die hervatting beinvloe- 
Tabel 1: Een overzicht van werkhervatting en faktoren die hervatting beinvloeden in twaalf geselekteerde onderzoeken.

\begin{tabular}{|c|c|c|c|c|c|c|c|}
\hline \multicolumn{2}{|c|}{ eorste auteur } & \multirow{2}{*}{$\frac{\mathbb{N}^{*}}{174}$} & \multirow{2}{*}{$\frac{\operatorname{logeftij} j}{25-64}$} & \multirow{2}{*}{$\begin{array}{l}\text { tijdstipper } \\
2 \text { w. } 5,12,18 \\
\text { mind }\end{array}$} & \multirow{2}{*}{$\frac{90}{90}$} & \multirow{2}{*}{$\begin{array}{l}\text { hervat } \\
<\text { mant } \\
79\end{array}$} & \multirow{2}{*}{ 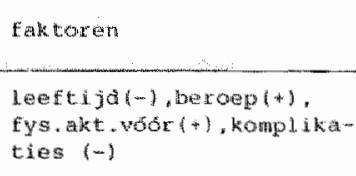 } \\
\hline Weinglat & $(1966)$ & & & & & & \\
\hline Garrity & $(1973 b)$ & 58 & $37-74$ & $2 \mathrm{w}$, Gmand. & 67 & 67 & 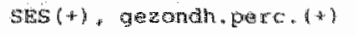 \\
\hline Croog & $(1977)$ & 293 & $30-60$ & $2 w_{*}, 12$ mad. & 8. & 73 & 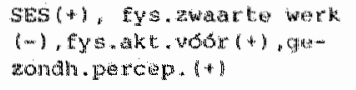 \\
\hline Cay & $(1973)$ & 105 & $16-79 * *$ & $2 w_{0} 4,12$ minc. & 70 & 69 & 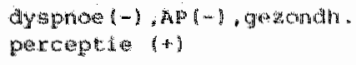 \\
\hline Kustat & $(1975)$ & 112 & 265 & 1. 4 mana. & 77 & & $\begin{array}{l}\text { perceptie ooxzatik m I } \\
\text { werk }(-)\end{array}$ \\
\hline Einlayson & $(1977)$ & 76 & -60 & $2 m, 6,12 \mathrm{mmd}$. & By & 77 & $\begin{array}{l}\text { leeftija (kromlijnig n! } \\
\operatorname{ses}(4), \text { optimismeg (w) }\end{array}$ \\
\hline Kentala & $(1972)$ & 142 & $\$ 65$ & 2 m. 12 mal. & 68 & $?$ & 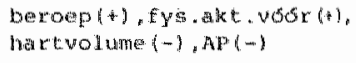 \\
\hline Kjo $11 \mathrm{Le}$ & $(1976)$ & 256 & -265 & gendid. $2 \mathrm{jr}$ & $8 ?$ & $z^{2}$ & 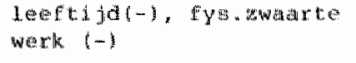 \\
\hline Widthelansse & $\ln (1976)$ & 266 & 65 & $\begin{array}{l}1 \text { wa, } 3,12,24 \\
\text { mand. }\end{array}$ & 70 & ? & Leeftidit $(-1)$ \\
\hline 3osten & $(197)$ & 980 & .065 & 3.9 mand. & 35 & $?$ & 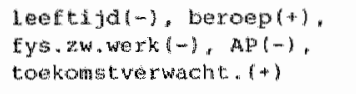 \\
\hline zile & $(1975)$ & 150 & 465 & 12 mand. & 57 & 25 & $\begin{array}{l}\text { leetijal }(-) \text {, beroep }(+) \\
\text { piek sgor }(-) \text {, Ap }(-) \\
\text { recidief }(-)\end{array}$ \\
\hline Vexmetilen & $(1978)$ & 92 & $40-55$ & $2,4,12 \mathrm{mnd}$ & 71 & 50 & $A P(-)$ \\
\hline
\end{tabular}

* Het total antial heeft strods betreking op de overlevenden

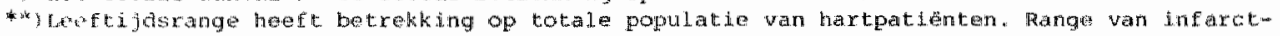
partionten in miet gegeveri. 
den. De tabel bevat steeds drie onderzoeken uit respektieve$11 \mathrm{jk}$, de U.S.A., Engeland, de Scandinavische landen en Nederland.

Er is bijna uitsluitend sprake van specifieke populaties uit Een of meer ziekenhuizen in een bepaalde stad of regio. AlLeen het onderzoek van Josten (1973) werkt met een steekproe: en wel ult dertiende weeksmeldingen van ziektewetgevallen aal de G.M.D. Het onderzoek beperkt zich tot die gevallen en dal nog alleen voor een pexiode van drie tot negen maanden na in. farct. Deze beperkingen verklaren warschijnlijk het nogal lage pexcentage werkhervatting. In slechts drie onderzoeken wordt gebruik gemaakt van geavanceerde multivariate analysetechnieken (Garrity, 1973 ; Kentala, 1972; Josten, 1973). In de overige onderzoeken is slechts sprake van bivariate of, in het gunstigste geval, trivariate analyses. Wat de hoogte van de hervattingspercentages betreft, kan volstaan worden met een verwijzing naar de eerdere konstatering over de verschillen tussen Angelsaksische, Scandinavische en Nederlandse cijfers.

In de tabel zijn voorts die faktoren opgenomen die in minimall twee onderzoeken voorkomen. Over de invloed van beroep op sociaal-ekonomische status blijkt de meeste overeenstemming te bestaan: patiënten met hogere beroepen hebben een grotere kans het werk te hervatten dan patiënten met lagere beroepen. Voorzover dit onderzocht is lijkt dit gegeven samen te hangen met de fysieke belasting van het werk. In schijnbare tegenspraak hiermee staat de bevinding dat een hogere mate van fysieke aktiviteit vór het infarkt juist een positieve invloed heeft op de werkhervatting. Men dient hierbij echter rekening te houden met het feit dat de fysieke belasting in het werk slechts én aspekt van de totade fysieke aktiviteit is. Bovendien worden beide faktorem in het algemeen met verschillende metoden vastgesteld. Het is merkwaraig te noemen dat de bevindingen ten aanzien van de faktor leeftijd zo weinig konsistent zijn. Toch kan op plausibele, zowel empirische als teoretische, gronden een negatief verband verwacht worden (Safilios-Rothschild, 1970). Een verklaring voor het ontbreken van een duidelijk negatief verband kan liggen in de aanwezigheid van een andere faktor die dit verband onderdrukt of modificeert. Deze verklaring wordt in elk geval aangevoerd door Finlayson en McEwen voor de merkwaardige kromlijnigheid (omgekeerde Uvorm) van het verband in hun onderzoek: in de middelbare 
leeftijasgroep blijken zich relatief veel patienten met een hoog beroep te bevinden.

Voorzover de ernst van het infarct is onderzocht, blijkt dat de mate van ernst -weliswaar op verschillende wijze geindiceerd- een negatieve invloed heeft op hervatting. Er zijn echter slechts twee onderzoeken waarbij de ernst in een multivariate analyse is betrokken. In éen pnderzoek blijkt geen effekt van de ernst (Garrity, 1973 ; peelindex) en in het andere (Kentala, 1972; haxt-volume) wel. De aanwezigheid van angina pectoris blijkt vooral op basis van het onderzoek van Kentala en Josten, een negatief effekt op hervatting te hebben. Recidief infarct heeft alleen volgens Kentala een negatief effekt, bij Lie et al. (1975) verdwijnt dit effekt bij kontrole op leeftijd.

De laatste faktor die, voorzover onderzocht, op het oog konsistente bevindingen oplevert, is de opvatting van de patiënt over zijn toestand. Er is echter niet eén onderzoek waarbij deze faktor gemeten is voór het tijdstip van hervatting en in een multivariate analyse is opgenomen. Het is echtex wel een tamelijk hardnekkige bevinding in bivariate analyses, zoals ook werd vermeld bij de behandeling van de gezondheidsperceptie-benadering.

De meerderheid van de overlevende patiënten blijkt het werk te hervatten en dus impliciet de rol van patiënt af te leggen. In hoeverre sprake is van een gehele of gedeeltelijke aflegging van die rol -dus of sprake is van gehele dan wel gedeeltelijke hervatting- is praktisch alleen voor de Nederlandse situatie gedokumenteerd. Bij de presentatie van de resultaten van het onderzoek zal op dit punt worden teruggekomen.

Een laatste opmerking bij het onderwerp hervatting geldt de afwezigheid in het onderzoek van ekonomische en bedrijfsgebonden faktoren bij de verklaring van verschlllen in werkhervatting. Toch is het besef hiervan reeds vroeg aanwezig geweest blijkens de volgende passage in het artikel van de WCU van het Bellevue ziekenhuis (1951): the state of the labor market may be more important than the state of the heart in this matter. In het onderzoek van weinstock et al. (1974) werd aan 125 bedrijfsartsen een casus gepresenteerd van een 38-jarige hartinfarctpatiënt zonder klachten, met de vraag of zij deze man weer het werk zouden laten hervatten; 31 van de bedrijfsartsen zouden hem niet laten hervatten in hun bedrijf als het een hoofdarbelder was en 65\% niet als het een handarbeider was. De reden voor deze terug- 
houdendheid was de angst voor law-suits, waardoor de patiënt aanspraak kan maken op een uitkering indien zich weer een cardial incident zou voordoen. Deze terughoudendheid doet zich, zij het in mindere mate, ook bij de werkgevers voor. Bovendien leefde de gedachte dat de infarctpatienten relatief veel zouden verzuimen en dus veel manuren verloren zouden gaan. Over faktoren betreffende arbeidsmarkt, ekonomische toestand van het bedrijf etc. is geen onderzoek bekend. Men moet er echter rekening mee houden dat naast bedrijfsgebonden faktoren, zoals bovengenoemde, ook, wellicht moeilijk te achterhalen, faktoren op arbeidsmarkt en meer algemene ekonomische faktoren een rol spelen bij werkhervatting.

De terugkeer naar het werk is een veel gebruikte mat voor objektief sociaal herstel. Wat betreft subjektief sociaal herstel geeft alleen het onderzoek van croog en Levine (1977) informatie. Eén jaar na infarct onderzochten zij de mening van de patiënt of het leven weer als normal werd beschouwd en de tevredenheid met de levensomstandigheden. Beide variabelen hangen samen met burgerlijke status: gehuwde mannen waren positiever op beide punten. Hetzelfde geldt voor de samenhang met het optimisme van de patiënt twee maanden na infarct: patiënten die toen optimistisch waren, vinden én jaar na infarct dat het leven zich weex genormaliseerd had en vertoonden een grotere tevredenheid dan patiënten die pessimistisch waren. De tevredenheid met de levensomstandigheden hangt voorts positief samen met inkomen en opleiding; terwijl de terugkeer tot een normale levensstijl negatief samenhangt met de zwarte van het werk vóor het infarct.

Daar deze laatste faktor samenhangt met beroep, kan gesteld worden dat het subjektief sociaal herstel gunstiq beinvloed wordt door een hogere sociaal-ekonomische status. Bovendien blijkt hier weer de gezondheidsperceptie een beinvloedende faktor te zijn.

\section{KONKLUSIES}

Het is niet eenvoudig alemene konklusies te trekken uit de gepresenteerde onderzoeken omtrent herstel. Er is een grote diversiteit aan metoden, patiëntengroepen en, bijgevolg, aan resultaten. 
over fysiek herstel in termen van maximal inspanningsvermogen kan worden gekonkludeerd dat korte tijd na het infarct, in het algemeen een relatief slechte lichamelijke konditie bestaat, die in de loop van circa én jaar enige verbetering ondergaat. Er blijken relatief veel (lets minder dan 50\% van de overlevenden) patiënten te zijn met klachten als pijn op de borst en kortademigheid, terwijl deze proportie maar nauwe 1 ijks $11 j k t$ te veranderen.

Het aktiviteitenniveau is in het algemeen blijvend verlaagd te noemen, zeker wanneer men afgat op het oordeel van de patiënt. Dit alles bij elkaar leidt tot de konklusie dat een niet te onderschatten aantal patiënten te kampen zal hebben met een funktionele handicap op grond van een, objektief of subjektief gezien, verminderd uithoudingsvermogen. Het onderzoek naar het verloop, in depressieve symptomen sluit min of meer aan bij deze konklusie: het voorkomen van klachten of verschijnselen die van het etiket depressieve symptomen kunnen worden voorzien, lijkt niet of in geringe mate af te nemen. Het sociale herstel geeft ten aanzien van seksuele aktivitelten, huishoudelijke taken en vrijetijdsaktiviteiten het beeld van het vermoedelijk blijvend verlaagde niveau van deze aktiviteiten.

voor werkhervatting als indikator voor sociaal herstel ligt de zaak wat ingewikkelder. In landen met hoge hervattingscijfers is men snel geneigd te konkluderen dat de resterende invaliditeit, op grond van de veronderstelde implikatie van fysiek en psychisch herstel, wel mee zal vallen. In de Nederlandse situatie, met lagere hervattingscijfers geldt dat sowieso sprake is van een niet onaanzienlijke arbeldsinvaliditeit. Daar in het onderzoek naar werkhervatting psychisch en soclaal herstel niet mede is betrokken, kunnen echter geen uitspraken gedaan worden over andere vormen van invaliditelt die $6 \delta k$ bij degerien die het werk hervat hebben een rol spelen. Daarbij komt nog dat in het algemeen geen onderscheid is gemakt tussen gehele of gedeeltelijke hervatting, zodat de gepresenteerde cijfers een te rooskleurig beeld geven.

Het fysieke herstel wordt in eerste instantie beInvloed door de ernst van de infarct. De invloed van de ernst op psychisch en sociaal herstel is minder duidelijk. Op deze vormen van herstel lijken vooral de sociaal-ekonomische status en de gezonaheidsperceptie van invloed. 
1.5 Relaties tussen Eysiek, psychisch en sociaal herstel Bij de bespreking van de onderlinge relaties tussen de onderscheiden herstelgebieden komen drie problemen aan de orde, name $1 \mathrm{i} j \mathrm{j} k$

a. of en in hoeverre er een relatie is tussen fysieke, psychische en sociale toestandsvariabelen,

b. of en in hoeverre herstel op het ene gebied een voorwaarde is voor herstel op een ander.

c. of en in hoeverre herstel op het ene vlak, min of meer gelijktijdig, gepaard gaat met herstel op een ander vlak.

ad a.: In het overzichtsartikel van Doehrman (1977) staat als konklusie voox de relatie fysiek - psychisch funktioneren na hartinfarct het volgende vermeld: 'The positive association between psychological functioning found in a handful of articles studying hospitalized patients is not seen when long-term rehabilitation is considered. Adjustment in one area does not, in many cases predict to adjustment in the other area'.

Hierbij doelt Doehrman vooral op het ontbreken van verbanden tussen exnstindikatoren en depressieve symptomen. Bovendien kan, zoals reeds werd vermeld, een gebrek aan relatie tussen objektieve en gepercipieerde ernst worden verondersteld. Over de relatie tussen fysieke fitheid en psychisch funktioneren bestaat al sinds eeuwen de veronderstelling van een positieve korrelatie naar het adagium 'Mens sana in corpore sano'. Toch zijn er vrijwel geen empirische studies, bij gezonde mensen wel te verstaan, die dit kunnen ondersteunen. De onderzoeken die ex zijn laten slechts zwakke verbanden in de verwachte richting zien (Borg, 1974). Dit is niet anders bij hartinfarctpatiënten. Zo vond Josten (1973) een signifikante max zwakke negatieve korrelatie tussen de maximalle zuurstofopname en de mate warin de patiënt zich belast voelt in het dagelijks leven. De relatie tussen de mate van fysieke aktiviteit en psychisch funktioneren is een weinig onderzochte.

In elk geval moet men aannemen dat depressieve symptomen een negatief effekt hebben op het ontplooilen van fysieke aktiviteiten (zie bijvoorbeeld Gelfland, 1959).

Bij de beschouwingen over sociaal herstel is al aannemelijk gemakt dat ernst van het infarct een negatief effekt heeft op de kans op werkhervatting. In dit geval is dus sprake van een verband tussen een bepaalde sociale situatie en de 
fysieke toestand. Iets anders ligt het voor het verschijusel dat diegenen die het werk hervatten in het algemeen fysiek fitter zijn dan de niet-hervatters. op zichzelf zal dit wel. juist zijn, maar de verklaring ligt dan veeleer hierin, dat om tot werkhervatting te komen eexst een bepaalde mate van fysiek herstel noodzakelijk is. De relatie hoort dan onder categorie b thuis.

In het onderzoek van Croog en Levine (1977) wordt uitvoerig aandacht besteed an de relaties tussen de psychische en sociale toestandsvariabelen éen jaar na infarct. Het blijkt dat deze bijna allemal hoog tot zeer hoog met werkhervatting en onderling samenhangen: de patiënten die het werk hervat hebben zijn niet depressief, hebben weinig klachten, vinden dat het leven weer normal is, vinden dat ze weer op niveau van fysieke aktiviteiten zitten van vór het infarct, etc. Het is met andere woorden dus blijkbaar zo, dat psychische en sociale toestandsvariabelen, met name via werkhervatting, nauw aan elkaar gerelateerd zijn.

ad $b$. : Uit het literatuuroverzicht betreffende herstel na hartinfarct is al naar voren gekomen, dat ten aanzien van de voorwaardelijkheid van de ene vorm van herstel voor een ander, al wel het een en ander bekend is, tenminste in die betekenis dat bepaalde toestandsvariabelen op het ene vlak voorspellers kunnen zijn voor toestandsvariabelen op een ander vlak op een later tijastip. Het tweede deel van het citaat uit Doehrman is dan ook niet geheel juist. Zo is gezondheidsperceptie een voorspeller voor werkhervatting, moeilifker worat het als men zich afvraagt of bijvoorbeela sociaal herstel meestal of noodzakelijkerwijs vooraf wordt gegaan door bijvoorbeeld fysiek herstel. Wel is evident dat een fysieke verslechtering, bijvoorbeeld in het onderzoek van Croog en Levine bij de heropgenomen patienten, soclaal en psychisch herstel belemmert. op aannemelijke gronden kan men wel verwachten dat sociaal herstel in het algemeen later, en, wellicht op basis van fysiek en psychisch herstel, zal plaats vinden. Het is uiteraard zeer relevant voor de gezondheldszorg te weten wanneer welk herstel het beste in gunstige zin beInvloed kan worden.

ad c.: De vraag of herstel op het ene vlak gepaard gat met herstel op een ander kan het best worden behandeld bij het overzicht van de effekten van revalidatie op herstel. Bij 
revalidatie wordt immers tenminste én aspekt van herstel systematisch beinvloed, warbij vaak veranderingen in andere aspekten mede worden gerapporteerd. Hier kan echter al worden opgemerkt dat ex in het algemeen te gemakkelijk van wordt uitgegaan dat bifvoorbeeld een verbetering van de luchamelijke konditie min of meer automatisch leiat tot een vermindering van depressieve symptomen of tot werkhervatting (Garrity, 1975).

\subsection{De invloed van revalidatie op herstel}

Begrippen

De bekendste definitie van revalidatie is die van de werelagezondheidsorganisatie (W.H.O.):

'onder revalidatie wordt verstaan alle noodzakelijke en moge. lijke aktiviteiten, die tesamen nodig zijn om een gehandicapt patiënt in de voor hem optimale, geestelijke en matschappelijke omstandigheden te brengen, waardoor het hem mogelijk wordt in verdere zelfontplooiing een zo volwaardig mogelijke plaats in de samenleving in te nemen' (Revalidatiecommissie NHS, 1966).

Deze definitie, die naw verwant is aan de gezondheidsdefinitie van de W.H.O., heeft een 1 deologische basis die teruggaat op de verklaring van de rechten van de mens.

Anno 1981 definieert men revalidatie liever zakelijk als volgt: 'Revalidatie is het geheel van gezondheidszorg aktiviteiten -met een begin en duidelijk einde- dat tot doel heef het fysieke, psychische en sociale herstel in positieve zin te beinvioeden".

Dit Ls in essentie de omschrijving van zowel wenger (1979) als van Weeda en Visser (1981). De term revalidatie wordt nogal eens verward met het begrip herstel, bijvoorbeeld in uitupraken als "de patiênt revalideert zichzelf" of 'werkhervatting is revalidatie" .

Bovenstaande omschrijwing gat echter nadrukkelijk uit van een in de tija nauw onschreven interventie van de gezondheids. zorg met als doel het herstel te bevorderen.

In het al eerder genoemde rapport van de Revalidatiecommissie van de N.H.S. (1966) worden vier fasen van behandeling onderscheiden: het acute stadium, de reconvalescentie, de rekonditionering en de resocialisatie.

In het acute stadium en tijdens de reconvalescentiefase vindt 
een geleidelijke mobilisatie van de patient plats middels bewegingsterapie. Indien nodig kan de patient dan verwezen worden naar een hartrevalidatie-afdeling of -centrum waar fysieke en psychische rekonditionering plaats vindt. Dan kan nog arbeidsrevalidatie of sociale revalidatie plats vinden. Dit geheel van aktiviteiten wordt dan begrepen als revalidatie.

In het overzicht dat weeda en visser (1981) geven voor de stand van zaken in Nederland blijkt dat onder hartrevalidatie in de praktijk meestal wordt verstaan: mobilisatie en/of fysileke rekonditionering. Revalidatie moet ook worden afgegrensd tegen secundaire preventie (Weeda, 1978). Bij het laatste gaat het om het bestrijden van die verschijnselen of faktoren die een negatief verloop van de ziekte kunnen bewerkstelligen.

Medikamenteuze behandeling van angina pectoris of ritmestoornissen is hier een voorbeeld van. De effekten van secundair-preventieve maatregelen worden in het algemeen bepaald an de hand van de criteria morbiditeit en mortaliteit. Voor revalidatie gelden die criteria eigenlijk niet, omdat deze aktiviteit zich richt op verbetering van het herstel van de patiënt in fysiek, psychisch en sociaal opzicht. Zo wordt bij hartrevalidatie fysieke training niet in eerste instantie toegepast om de voortgang van het atherosclerotisch proces te vertragen, maar om effekten te bereiken als verbetering van lichamelijke fitheid, efficiëntere circulatie en het verminderen van angst (wenger, 1977). Toch is ten aanzien van fysieke training aan te voeren dat deze interventie zowel ondergebracht kan worden bij secundaire preventie, namelijk voor zover men van mening is dat fysieke training alrekt of indirekt van invloed is op de prognose na infarct, als bij revalidatie, omdat training beoogt het fysiek herstel rechtstreeks te beinvloeden. Deze redenering leidt tot een ordening van gezondheidszorgaktiviteiten als in figuur 1. Wanneer in het navolgende gesproken wordt over fysieke training, geschiedt ait in het kader van revalidatie, net andere woorden cxiteria als morbiditeit en mortalitelt komen niet of nauwelijks aan de orde. 
Figuur 1: Revalidatie en secundaire preventie bij hartinfarctpatienten

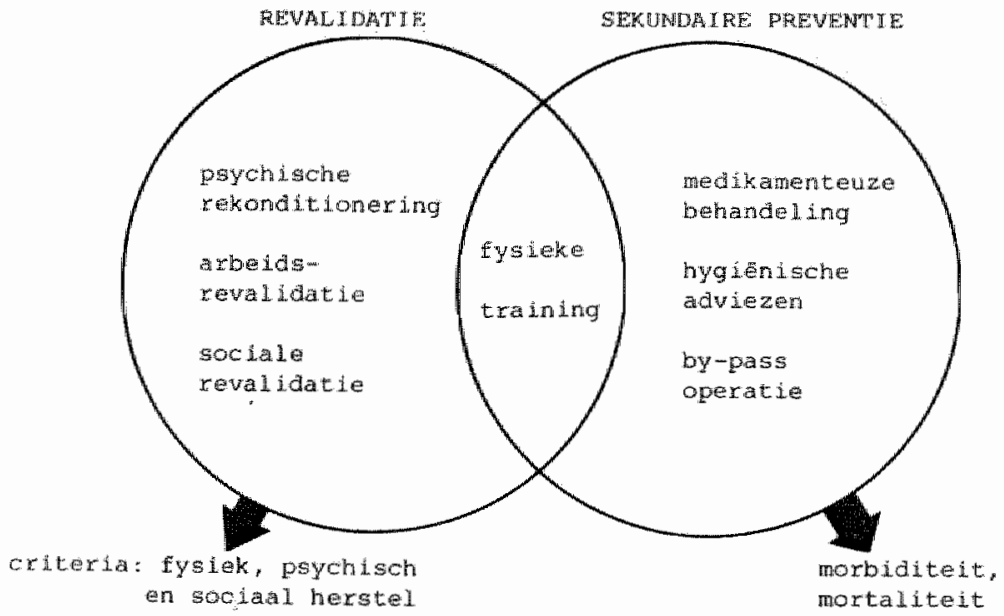

De effekten wan fysieke rekonditionering op herstel

Het zwaaxtepunt van het betoog zal vallen op fysieke training of fysieke rekonditionering, omdat verreweg de meeste revalidatieprogramma's ofwel hiermee praktisch identiek zijn, ofwel dit als 'harde kern' hebben. De traditie van de gezondheidszorg in een bepaald land lijkt vooral te bepalen hoe de revalidatie ex uit zal zien. In de Angelsaksische landen zijn er meestal simpele trainingsprogramma"s, terwijl in west-Duitsland en oost-Eurapa de revalidatie meer gebaseerd is op het kurort-principe (Working Party of Royal College of phyons, 1975). Hoe dit ook zij, fysieke training is $\mathbb{i n}$ alle programma's aanwezig en bijgevolg is het meeste empirische materiaal op dit punt beschikbaar. De vroege moblilisatie van de patient, dat wil zeggen de $-2 i j$ het lichte- fysieke training wlak na het acute stadium werd tot in de vijetiger jaren als riskant beschouwd. Een langdurige bedrust -zo'n vier weken- wexd dan ook aanbevolen. Pas toen de dekonditionerende effekten van langdurige bedrust duidelijk werden en bovendien steeds meer aanwijzingen kwamen dat vroege mobilisatie in elk geval geen negatieve gevolgen had, werd de duur van de ziekenhuisopname geleidelijk teruggebracht tot een à twee weken en vroege mobilisatie als standaardbehandeling ingevoerd (Williams et al., 1976; Wenger, 1979; Bramme11, 1980). De effekten van vroege mobilisatie liggen onbetwistbaar ir de preventie van fysieke dekonditionering (Wenger, 1979) en 
misschien in de preventie var angst en depressie (Groden en Brown, 1970; wengex, 1979) en van arbeidsinvaliditeit (Bloch et al., 1974). Overigens lijkt binnen kortdurende opnames geen positief of negatief effekt van lichte training op het prestatievermogen te kunnen worden aangetoond (sivarajan et al. 1981).

De twee skandinavische trials (Helsinki en Götenborg) zijn tot op heden de enige onderzoeken die een antwoord geven op de effekten van fysieke training op objektief fysiek herstel.

In beide experimentele groepen werd tussen twee à drie maanden en één jaar na infarct een winst in maximaal prestatievermogen geboekt van circa 20: In de Helsinki trial trad die winst echter óok op in de kontrolegroep (Kentala, 1972). In de Götenborg trial boekte de kontrolegroep een signifikant lagere winst van 12 in prestatievermogen (wilhelmsen et al. , 1975). Beide onderzoeken hadden te kampen met een flinke drop-out rate (>50\%) in de trainingsgroep. Dit probleem doet zich in zo'n ernstige mate voor bij de nog in gang zijnde grootste trial op dit gebied in Southern Ontario $(n=750)$ dat de oorspronkelijke doelen -namelijk uitspraken over morbiditeit en mortaliteitwaarschijnlijk nilet zullen worden gehald (Shephard, 1979 , 1981).

In de tweede grote trial $(n=651)$, het 'National Exercise and Heart Disease project" (NEHD) (Naughton, 1978) komt dit arop-out probleem niet in ernstige mate voor. Voorlopige resultaten laten een winst in prestatievermogen zien voor de trainingsgroep gedurende de eerste zes maanden van het onderzoek. Eén jaar na randomisatie gaan zowel trainingsals kontrolegroep achteruit (Tristani, 1980). Geen dex genoemde onderzoeken, waarbij het om langdurige trainingsprogramma's gaat (twee tot drie mal per week gedurende minstens tien maanden) laat overigens noemenswarardige effekten zien op cardiovasculaire mortaliteit (Shephard, 1981; Tristani, 1980).

In een Nederlands onderzoek met een gerandomiseerde opzet (Vermeulen et al., 1978) werden de effekten van een kortdurend trainingsprogramma (twee maanden) geëvalueerd. Deze auteurs gebruikten een voor Europa wat ongebruikelijke maat voor inspanningsvermogen, namelijk de totale tredmolen- 
tijd in sekonden. De trainingsgroep $(n=42)$ boekt een winst van 21: tijdens de trainingsperiode (twee tot wier maanden na infarct). Eén jaar na infarct was het trainingseffekt zo goed als verdwenen. De kontrolegroep $(n=50)$ ging over de gehele periode zo'n $11 \%$ vooruit.

In de Turku-Helsinki trial $(n=375)$ is een kombinatie-interventie toegepast: het trainingsprogramma werd aangevuld met GVO-aktiviteiten. Er zijn geen verschillen in prestatievermogen tussen interventie- en kontrolegroep op een, twee en drie jaar in infarct. Wel treden in de interventiegroep signifikante dalingen in systolische en diastolische bloeddruk in rust, gewicht en serumcholesterol op (Kalio et al., 1979). De resultaten van deze trial ondersteunen in elk geval niet de veronderstelling van shephard (1981) dat verbetering van het prestatievermogen een gezondere levensstijl bevordert en het effekt van fysleke training op de prognose dus indirekt, namelijk via bejnvloeding van risikofaktoren, zou verlopen. In de Turku-Helsinki trial trad in het eerste half jaar in de interventiegroep signifikant minder plotse dood op dan in de kontrolegroep. Dit effekt is echter niet zonder meer toe te schrijven aan het interventieprogramma, daar patiënten uit de interventiegroep tweemal zoveel kontakt hadden met een arts en in grotere getale B-blokkerende middelen gebruikten als patiënten uit de kontrolegroep. In de tot nu toe genoemde onderzoeken -op één na- zijn behalve werkhervatting geen psycho-sociale effektmetingen opgenomen. In het NEHD-projekt zijn ze wel opgenomen max nog niet gerapporteerd.

Een belangrijke, vooral op klinische indrukken gebaseerde, veronderstelling is dat fysieke training en toename in prestatievermogen gepaard gat met vermindering van depressie, verbetering van het welbevinden e.d. (Hackett en Cassem, 1973; wenger, 1979). Er zijn wel een aantal niet gerandomiseerde onderzoeken bekend waruit zou moeten blijken dat winst in prestatievermogen gepaard gaat met een verbetering van welbevinden (Hellerstein en Hornstein, 1966; Bruhn, 1973; Carson et a1., 1973; Verstappen et al., 1974; Kavanagh, 1977) In dxie onderzoeken die met een vergelijkingsgroep werken, werden echter geen, of niet overtuigende verschilien gevonden tussen getrainden en niet-getrainden op dit punt (Rechnitzer, 1967; McPherson et a1., 1967; Naughton, 1968). In een onder- 
zoek onder hartinfarctpatienten en patienten na een by-pass operatie vonden soloff en Bartell (1979) na training zowel een verbetering in prestatievermogen als een stemmingsverbetering, de twee verbeteringen waren echter statistisch onafhankelijk van elkaar. Men moet dan ook vaststellen dat de indruk, dat patienten psychisch herstellen door fysieke training, nog steeds onvoldoende empirische steun heeft (Doehrman, 1977; Shephard, 1981).

Parallel aan bovenstaande veronderstelling is vaak geopperd dat fysieke training sociaal herstel in casu werkhervatting zou bevorderen. Het enige onderzoek dat op ait punt positieve resultaten laat zien is het vergelijkende onderzoek van Kellerman et al. (1968). Kentala (1972) en vermeulen et al. (1978) vonden geen positieve invloed op het percentage hervatters van fysieke training. In het laatst genoemde onderzoek werd, integendeel, gevonden dat de deelname aan fysieke training de werkhervatting vertraagt. Wel kwamen de getrainden tot een hoger percentage volledige hervatting.

\section{KONKLUSIES}

Fysieke rekonditionering onmiddellijk na het acute stadium - ook wel aangeduid als vroege mobilisatie- voorkont in het algemeen een al te sterke daling van het lichamelijk prestatievermogen. De invloed van vroege mobilisatie op het psychisch en sociaal herstel is minder duidelijk. Omdat in elk geval vaststaat dat er geen negatieve gevolgen zijn en een kortere hospitalisatie ekonomisch aantrekkelijk is, heeft niets de geleldelijke invoering van vroege moblilsatie in de weg gestaan.

De fysieke tralning na ontslag lijkt in elk geval een effekt te hebben op het objektlef fysiek herstel in de zin van verbetering van het maximale prestatievermogen. De versohillende onderzoeken zijn niet altijd makkelijk te vergelijken ten aanzien van aard en intensiteit van de trainingsprogramma's. Soms wordt zelfs geen melding gemaakt van de tralningsopbouw. In elk geval is duidelijk dat bij een voldoende belasting - tot $80 \%$ van de individuele maximale hartfrekwentie- en voldoende frekwentie van dynamische trainingssessies -minimaal arie maal per week een half uur- het maximale prestatievermogen van infarctpatiënten in vier tot zes weken met zo'n 10 à $20 \%$ zal toenemen (Weeda, 1978). Deze orde var 
grootte van verbetering wordt, in het algemeen gesproken, gevonden in de geciteerde onderzoeken.

Het probleem is, in hoeverre de trainingswinst -na een korte maar intensieve trainingsperiode- behouden blijft. Het onderzoek van vermeulen et al. (1978) wijst uit dat de trainingswinst na enige tijd verdwenen is. De Angelsaksische en Skandinavische programma"s kennen veel langere trainingsperiodes. In de onderzoeken die in deze landen gedaan zijn, wordt men gekonfronteerd met een aanzienlijke drop-out in de trainingsgroepen, zodat uitspraken over langdurige training bemoeilijkt worden. Op zijn minst zou dit echter reden tot twijfel moeten geven voor de uitvoerbaarheid van zulke programma's. Er is -blijkbaax- een verschil in filosofie achter kortdurende en langdurende programma's.

Bif training van korte duur wordt uitgegaan van 'het duwtje in de goede richting', verbetering prestatievermogen, zelfvertrouwen en verder, bij langdurige training gaat het meer om het aanleren van fysieke inspanning als gewoonte (Wenger, 1976).

op basis van de geciteerde literatuur kan het -voorlopige oordeel- niet anders dan nogal negatief uitvallen voor beide vormen van training. Op $z i j n$ best is er sprake van een tijdelijke trainingswinst, en de transfer van trainingswinst naar psychisch en sociaal herstel is dubieus.

De effekten van psychische rekonditionering en psycho-sociale revalidatie op herstel

over de effekten van geisoleerde psychologische interventieprograma's op herstel na hartinfarct is bijzonder weinig bekend. Er is zegge en schrijve eén vergelijkend onderzoek onder 118 (mannelijke en vrouwelijke) patiënten betreffende de effekten van groepspsychoterapie (Ibrahim et al., 1974). In wekelijkse anderhalf uur durende sessies werden onder leiding van een klinisch psycholoog persoonlijke gevoelens en houdingen ter diskussie gesteld. De follow-up metingen vonden plaats respektievelijk 6,12 en 15 maanden na MI. De resultaten werden vergeleken met die van een niet-behandelde groep. Er werden geen verschillen gevonden tussen beide groepen. Zo verminderde in beide groepen de geinvolveerdheid met het werk en de gezins- en vrijetijasaktiviteiten. Het enige verschil was dat de vergelijkingsgroep zich meer so- 
ciaal vervreemd ging voelen in vergelijking met de behandelde groep.

Het feit dat zo weinig bekend is over psychologische interventie is vanzelfsprekend terug te voeren op het weinig voorkomen van deze vorm van interventie. In tegenstelling tot fysieke training acht men psychologische interventie slechts noodzakelijk bij een beperkt aantal patienten (zie bijvoorbeeld Johnson, 1976), in de al eerder genoende overtuiging dat fysieke training ook het psychisch herstel wel zal beinvloeden. Toch zijn er wel aanzetten tot geavanceerde interventies ( $\mathrm{v}$. Oost en Depoorter, 1976; Boudrez, 1977), waarover evenwel nog geen onderzoeksresultaten bekend zijn. Geisoleerde psychosociale interventie komt ook weinig voor. Een voorbeeld is het onderzoek naar het effekt van de werkwijze van een speciale cCu-verpleegster, die met een agressief programma met psycho-sociale steun en GVO trachtte de medische kennis te vergroten en de angst te verminderen, dit alles met het doel de kans op werkhervatting te vergroten (Pozen et al., 1977). Het ondexzoek, dat een gerandomiseerde opzet had, laat positieve resulaten zien voor de behandelde groep ten aanzien van werkhervatting, rookgewoonten en medische kennis. Bij kontrole op de statistische werkwijze blijken echter met name de geclaimde resultaten voor werkhervatting niet signifikant te zijn.

\section{KONKLUSIES}

In tegenstelling tot fysieke training komen geisoleerde psychologische en psycho-sociale interventies weinig voor. De enkele onderzoeken op dit gebied laten weinig positieve resultaten zien. Alleen GVo-aktiviteiten lijken enige vrucht af te werpen.

De effekten van revalidatie op herstel

Het begrip revalidatie wordt niet alleen vaak verward met herstel, maar ook met fysieke rekonditionering. In het Angelsaksische taalgebied is de term comprehensive rehabilitation ingevoerd om het noodzakelijke onderscheid te maken tussen $f_{Y-}$ sieke training en het meer omvattende begrip revalidatie. ook in Nederland bestaat deze verwarring, getuige een in 1979 gehouden inventarisatie waaruit onder andere bleek dat de ak- 
tiviteiten van arts plus fysioterapeut door de betrokkenen aangeduid werden als revalidatie (Weeda en visser, 1981). Men moet ex dus op bedacht zijn dat de term 'revalidatie' in de praktijk van alles kan inhouden wat te maken heeft met de nazorg van hartinfarctpatiënten.

In de Angelsaksische landen wordt meestal bedoeld: fysieke training eventueel met patient education-programma's

(Wenger, 1976). In Nederland wordt meestal bedoeld: fysieke training eventueel met psycho-sociale begeleiding. In onze optiek zouden zeker de eerstgenoemde programma's niet als revalidatie gekenmerkt moeten worden, maar als secundaire preventie. Dit blijkt ook wel uit de doelstellingen van dit soort programma's, die met name ook in Finland populair zijn (Kalio et al., 1979; Salonen en Puska, 1980): men beoogt morbiditeit en mortaliteit in gunstige $z$ in te beinvloeden. Nogmaals willen we erop wijzen dat volgens de gangbare definities revalidatie het funktioneren van de patient in fysiek, psychisch en sociaal opzicht beoogt te vexbeteren. Dit betekent dat naast fysieke training ook omschreven psycho-sociale interventies aanwezig moeten $z i j n$.

Het aantal programma's dat volgens de hier gehanteerde omschrijving is opgezet of deze benadert, is gering, het aantal effektonderzoeken is zo mogelijk nog geringer. Het enige onderzoek met een gerandomiseerde opzet komt uit Nederland en betreft het op de CAPRI-leest (Pyfer et al., 1976) geschoeide revalidatieprogramma in Rotterdam (Schelling, Erdman 1979). In dit onderzoek onder 80 mannelijke infarctpatienten kreeg de interventiegroep $(n=40)$ gedurende zes maanden tweemal. per week een anderhalf uur durende fysieke training plus begeleiding door psycholoog, sociaal-verpleegkundige en matschappelijk werkende. De precieze ara van deze begeleiding wordt niet vermeld. Het programma blijkt geen effekt te hebben op het maximale prestatievermogen: de interventilegroep boekt een winst van $10 \%$ tegen de kontrolegroep $6 \%$ (schelling, 1979). Het enige effekt op psycho-sociaal gebied is dat van een sociaal adekwatere manier van funktioneren in de interventiegroep: de patiênten uit deze groep worden minder terughoudend, minder gereserveerd, minder zwijgzaam (Examan, 1979). 


\section{KONKLUSIES}

Revalidatieprogramma's waarbij zowel fysiek, psychisch en sociaal herstel systematisch worden beinvloed, zijn vrij zeldzaam. Een onderzoek naar de effekten van een programma dat het ideale model benadert, in casu het CAPRI-projekt in Rotterdam, laat weinig indrukwekkende resultaten zien. Het is natuurlijk mogelijk dat de eisen die het revalidatiemodel stelt te hoog gegrepen zijn. Maar zelfs als die eisen wat soepeler worden gehanteerd, en biyvoorbeeld de aanwezigheid van bepaalde disciplines (arts, fysioterapeut, maatschappelijk werkende) als voldoende indikatie wordt beschouwd voor revalidatie als hier bedoeld, dan nog blijft het probleem dat geen adekwaat onderzoek bekend is van dit soort revalidatie, die in Nederland op zeker vijf plaatsen wordt beoefend ( $\mathrm{v}$. Nieuwenhuizen, 1971; Weeda en visser, 1981).

\subsection{Nabeschouwing}

Bij het evalueren van de effekten van de verschillende interventies stuit men op een aantal problemen:

1. Fysieke training is een omschreven en te standaardiseren interventie, terwij1 psycho-sociale interventie weliswaar omschreven kan worden, maar lang niet altijd te standaardiseren is.

2. De meeste programma's gaan ervan uit dat de intexventies in principe voor alle hartinfarctpatiënten zonder kontraindikaties gelden. Dit moge in zijn algemeenheid juist zijn voor vroege mobilisatie, voor interventies casu quo revalidatie na ontslag is er nu juist een probleem ten aanzien van de indikatiestelling (wenger, 1979), Er is met andere woorden nog onvoldoende inzicht in de vraag welke patienten het meest profiteren van welke interventies.

3. Het meest geciteerde onderzoek is onvolledig in de beschrijving van de interventie en van de herkomst dex onderzochte groepen.

4. Er is een grote verscheidenheld van criteria aan de hand waarvan de effekten zijn of kunnen worden geëvalueerd. Het probleem is nu dat zelden of nooit fysiek, psychisch en sociaal herstel tegelijkertijd in het onderzoek werden betrokken (Garrity, 1975) en dat verzuimd is objektief en subjektief herstel in de evaluatie te betrekken (dit 
is een algemeen probleem van revalidatie-onderzoek, Safilios-Rotschild, 1970). Een zodanige benadering vereist echter onderzoek vanuit een koherent gezichtspunt met inachtneming van de multidimensionaliteit van herstel. Het is dan mogelijk te komen tot een zuiniger en adekwater gebruik van criteria.

Veel, zo niet alle, van de genoemde problemen zijn onzes inziens terug te voeren op het gebrek aan inzicht in herstel, zowel in beschrijvende (het verloop van fysiek, psychisch en sociaal herstel) als in verklarende betekenis (determinanten van herste1).

Het is zeker niet de pretentie van de hierna gepresenteerce onderzoeken, die beide de invloed van revalidatie en fysieke rekonditionering op herstel als centraal probleem hebben, mel deze problemen af te rekenen. Wel zal zoveel mogelijk rekeni. worden gehouden met de drie deelgebieden van herstel en met het onderscheld objektief - subjektief herstel.

Aan het bezwaar genoema onder 2 kan hier niet tegemoet gekomen worden, omdat in de revalidatie-praktijk een duidelijke indikatiestelling nu eenmal ontbreekt. 


\section{Probleemstelling en opzet van de twee betrokken onderzoeken.}

\subsection{Inleiding}

In het voorwoord is reeds gemeld dat twee onderzoeken in de beschouwingen zullen worden betrokken:

- het eerste betreft een beschrijvend epidemiologisch onderzoek op landelijke schaal naar wijze en mate van werkhervatting na hartinfarct en de rol van revalidatie hier in. Dit onderzoek zal verder worden aangeduid met de nam CARGO-ONDERZOEK, op grond van het feit dat de commissie vour Arbeidsgeneeskundig onderzoek (TNO) de opdrachtgeefster ervan was.

- het tweede onderzoek is een kleinschalig, experimenteel opgezet onderzoek naar de effekten van de hartrevalidatie, zoals die plaats vond in het Rijnlands Zeehospltium te Katwijk onder verantwoordelijkheid van de afdeling cardiologie van het Academisch Ziekenhuis te Leiden (AzL). Kortheidshalve $\mathrm{krijgt}$ dit onderzoek de naam Leidse onderzoek. Nu reeds zij opgemerkt, dat de resultaten van het Leidse onderzoek voor zover mogelijk, vergeleken zullen worden met de gegevens van in 1973 te Katwijk gerevalideerde hartinfarctpatiënten.

\subsection{Het CARGO-onderzoek}

Probleemstelling

De vraag naar de effekten van hartrevalidatie leefde ook in arbeidsgeneeskundige kringen. Men hoopte op, vanzelfsprekend positieve, effekten van revalidatie ten araien van werkhervatting en ziekteverzuim na hervatting.

Met deze resultaten zou dan de terughoudendheid bij artsen, werkgevers en publiek ten aanzien van reintegratde kunnen worden verminderd (van Nieuwenhuizen 1971). Binnen de Nederlandse Vereniging voor Arbeids- en Bedrijfsgeneeskunde (NVAB) en de CARGO-TNO was het idee gerijpt bedrijfsartsen als informanten te gaan benutten over de lotgevalien van de hun bekende hartinfarctpatiënten. Daar behalve het ontbreken van inzicht in de effekten van revalidatie op hervatting ook beschrijvende cijfers op landelijke schal ontbraken, werd een ruime probleemstelling gehanteerd: 
- op welke wijze en in welke mate hervatten hartinfarctpatiënten het werk en welke faktoren hangen samen met hervatting en suksesvolle hervatting.

Deze probleemstelling is uiteen te leggen in vier deelvraagstellingen:

1. De mate van hervatting: hierbij gat het om de vraag welk deel van de onderzoeksgroep tot gedeeltelijke dan wel tot gehele hervatting komt;

2. Bij de wijze van hervatting wordt ingegaan op de vraag hoeveel tijd verloopt tussen infarct en hervatting en in hoeverre het werk meteen geheel dan wel eerst gedeeltelijk en daarna geheel wordt hervat;

3. Faktoren die samenhangen met hervatting: hierbij komt de vraag aan de orde welke persoonsgebonden faktoren als leeftijd, beroep, komplikaties e.d. en welke behandelingsfaktoren, waarvan revalidatie in dit onderzōek de belangrijkste is, samenhangen met hervatting;

4. Het sukses van de hervatting wordt hier opgevat als de vraag naar definitieve of tijdelijke uitval uit het arbeidsproces na aanvankelijke hervatting en als de vraag naar het oordeel van de bedrijfsarts en patiënt over het welslagen van de hervatting.

\section{Opzet van het CARGO-onderzoek}

Begin 1975 werden de bedrijfsartsen via het informatiebulletin van de NVAB geattendeerd op het onderzoek. Nadat opzet, uitvoering en financiering geregeld waren, volgde in augustus van dat jaar namens de CARGO een oproep aan de bedrijfsartsen mee te werken aan het onderzoek. De deelnemende artsen kregen een introduktiebrief, een aantal vragenlijsten en een toelichting op de invulling ervan (Diederiks, 1980).

Het onderzoek heeft betrekking op mannelijke werknemers van bedrijven met een bedrijfsgeneeskundige dienst (een eigen dienst of een gekombineerde dienst), die tussen 1 oktober 1975 en 1 oktober 1977 een hartinfarct, eerste of recidief, kregen. Er is geen sprake van een a-selekte steekproef ult de leden van de werkende mannelijke bevolking die in de genoemde periode door een hartinfarct werden getroffen:

a. de bedrijfsgeneeskundige diensten bestrijken niet de gehele werkende bevolking, 
b. de deelnemende artsen zijn op basis van vxijwilligheid bij het onderzoek betrokken,

c. er is geen absolute zekerheid dat de bedrijfsartsen alle infarctpatiënten in de bedoelde periode hebben kunnen signaleren.

Deze beperking betekent dat de resultaten van het onderzoek niet zonder meer kunnen worden gegeneraliseerd naar de mannelijke werkende bevolking en zelfs niet naax alle werknemers vallend onder de bedrijfsgeneeskundige diensten. Belangrijker is evenwel de vraag of de verkregen ondexzoeksgroep een onbevooroordeelde selektie is in relatie tot variabelen uit de vraagsteling. Er zal met andere woorden moeten worden nagegaan of de onderzoeksgroep op bepaalde aspekten een positieve dan wel negatieve selektie vormt.

De te verzamelen gegevens werden door de bedrijfsarts op de gestruktureerde vragenlijst ingevuld. Zodra hij hoorde dat een werknemer door een hartinfarct getroffen was kon hij met de invulling ervan beginnen. Daar de vragenlijst zoveel mogelijk het proces volgt dat iemand na een hartinfarct doormakkt, konden de verdere gegevens suksessievelijk worden ingevuld. De inzending van de kompleet ingevulde formulieren diende te geschieden:

- na overlijden,

- zes maanden na werkhervatting,

- dan wel twaalf maanden na infarct, indien geen hervatting had plaats gevonden.

Het eerste deel van de vragenlijst bevat de onafhankelijke variabelen als leeftija, beroep, geschatte belasting in de arbeidstaak, gegevens betreffende het ziekenhuis van opname en aard en duur van de verdere behandeling. Het tweede deel bevat de afhankelijke variabelen: werkhervatting, ziekteverzuim in de eerste zes maanden na hervatting en een aantal subjektieve oordelen van patient en bedrijfsarts over het sukses van de hervatting, de bereikte lichamelijke konditie en de algemene levensomstandigheden. 


\subsection{Het Leidse onderzoek}

\section{Probleems telling}

In 1970 werd in vijf centra officieel begonnen met hartrevalidatie. Enkele centra, met name Leiden, waren toen al enkele jaren bezig met het ontwikkelen van een programma. Bij de offlcielle start werd reeds de wens tot evaluatie geuit (van Nieuwenhuizen, 1971; Diederiks, 1972).

Het revalidatieprogramma zoals dat in Katwijk tijdens de onderzoekperiode (1974-1978) gerealiseerd werd, had de volgende kenmerken:

a. poliklinische revalidatie te beginnen circa twee maanden na infarct met een duur van 10 weken,

b. veertig trainingssessies (fietsen, sport en spel): gedurende de eerste vijf weken vijf keer per week, de volgende vijf weken drie keer per week. Een trainingssessie duurde cira éen uur.

c. groepsgesprekken met de maatschappelijk werkende in twee vormen: de maatschappelijk werkende probeerde de onderwerpen die spontaan aan de orde kwamen tijdens de informele gesprekken vór en na training,bespreekbaar te maken en op vrijwillige basis kon men deelnemen aan groepsgesprekken met zes patiënten,

d. individuele gesprekken met de maatschappelijk werkende,

e. in voorkomende gevallen: arbeidsbemiddeling door distriktsverpleegsters van de Sociaal Medische Dienst.

Het team bestaande uit een arts, distriktsverpleegsters, matschappelijk werkenden en fysioterapeuten, beoogde met de revalidatie (den Dekkex en Schnepper, 1973):

1. verbetering van het lichamelijk prestatievermogen,

2. stimuleren van het zich weer blootstellen aan lichamelijke en geestelijke inspanning,

3. hulp ten aanzien van arbeldsbemiddeling door verwijzing naar betrokken instanties,

4. lexen leven met de klachten, zoals die ook tijdens de training optreden,

5. opsporing en behandeling van aritmieën,

6. hulp bij het verwerken van problemen rond ziekte, handicap en verstoring van sociale kontakten,

De groepsgesprekken en individuele gesprekken waren in eerste instantie bedoeld voor de patienten. Ex werd echter naar 
gestreefd de partners zoveel mogelijk bij deze gesprekken te betrekken. In vergelijking met de fysieke training hadden de gesprekken een meer vrijblijuend karakter. Het revalidatieprogramma voldoet dus niet geheel an de eis dat nast een omschreven fysieke ook een omschreven psychosociale interventie aanwezig moet zijn. Het is echter wel duldelijk dat voor de psycho-sociale aspekten een ruime plaats was ingeruima. Het programma kwam bovendien overeen met andere programma's warvoor een voorlopige erkenning was afgegeven. Er bestond cus, met andere woorden, een zekere mate van overeensteming over de benoeming van dit soort programma's als hartrevalidatie.

In het onderzoek zal het gehele revalidatieprogramma als én interventie worden beschouwd. Er zal met andere woorden niet op de effekten van de afzonderlijke interventies worden geëvalueerd. Hiervoor zijn twee redenen aan te geven. Ten eerste was de psycho-sociale interventie niet duidelijk omschreven. Ten tweede zou, als men de gegeven psycho-sociale begeleiding als interventie wenst te beschouwen, een opzet moeten worden gekozen waarin een groep patiênten uitsluitend deze vorm van interventie zou ondergaan. Ondat ook de patiënten de fysieke training als de harde kern van het programma zagen, achtte men dit ongewenst. Aan de andere kant is het ook niet mogelijk uitsluitend de effekten van de fysieke training te onderzoeken, daar het niet uit te sluiten is dat de psycho-sociale begeleiding invloed heeft op het fysieke herstel.

Men ontkomt er dan niet aan het totale pakket als de te onderzoeken interventie te beschouwen.

De vraag die men zich bij de evaluatie stelde was in wezen een hele simpele: wat wordt ex gewonnen met hartrevalidatie in vergelijking met de gebruikelijke polikilnische nazorg? De probleemstelling van het Lejdse onderzoek gatat ook van deze vraag wit:

- in hoeverre levert het poliklinische revalidatieprogramma van katwijk "betere' resultaten op dan de gebruike1 ijke poliklinische nazorg van het Academisch zlekenhuls Leiden.

De probleemstelling kan als volgt worden gespecificeerd (zie ook Diederiks, 1972):

1. wordt door revalidatie een winst in het maximale presta- 
tievermogen bewerkstelligd, die groter is dan de "normale" stijging die optreeat zonder specifieke interventie en zo ja, beklijft die winst dan na revalidatie,

2. wordt de trainingswinst ongezet in een verhoging van aktiviteiten in het dagelijks leven,

3. wordt door revalidatie het subjektief welbevinden positief beinvioed.

4. In hoeverre gaan objektief en subjektlef herstel onder invloed van de revalidatie samen,

5. in hoeverxe wordt de partner door de revalidatie beinvloed en wat zijn de effekten hiervan op het funktioneren van de patiënt.

De resultaten van het onderzoek die hier gepresenteerd worden hebben vooral betrekking op deelvraagstellingen $3 t / m 5$, daar de meer inspanningsfysiologisch getinte vraagstellingen 1 en 2 niet geheel binnen het bestek van deze verhandeling vallen.

Opzet van het Leidse onderzoek

Het onderzoek kent een experimentele opzet. Vanuit één groep patiënten met nader te specificeren kenmerken werden via een randomprocedure twee groepen geformeerd, én onderging de experimentele konditie, in casu de revalidatie te Katwijk, de andere kreeg uitsluitend de gebruikelijke poliklinische nazorg. De randomisering vond plaats binnen vooraf gekozen strata van de faktoren leeftijd (beneden de 55 jaar en 55 jaar en ouder), beroep (laag, zelfstandig, hoog), en angina pectoris (al of niet aanwezig). Op deze wijze werd er zorg voor gedragen dat experimentele en kontrolegroep in elk geval op deze faktoren vergelijkbaar zouden zijn. De metingen vonden plaats op drie, zes, twaalf en vierentwintig maanden na datum hartinfarct. De revalidatie vond plaats tussen de drie en zes maanden na infarct. De followup metingen waren dus respektlevelijk een en twee jaar na infarct. Op elk meettijdstip vonden de volgende metingen plaats: inspanningsonderzoek, psychologische testen, medische vragenlijst, interview voor de vaststelling van het aktiviteitenpatroon en sociale vragenlijst. Indien de patiënt gehuwd was, dan wel duurzaam samenwoonde kreeg de partner eveneens de medische en de sociale vragenlijst voorgelegd. De vragenlijsten hebben een gestruktureerd karakter en wer- 
den door man en vrouw afzonderijk ingevuld. Na het invullen bespraken de onderzoekers de eventuele onduidelijkheden in de vragenlijsten.

Het hoe en warom van de afzonderlijke metingen zal besproken worden bij de presentatie van de betreffende resultaten. Hier kan volstaan worden met een indeling van de in het onderzoek betrokken variabelen.

De revalidatie in Katwijk is de onafhankelijke variabele en wordt geacht invloed te hebben op een antal oriteriumvariabelen, terwijl tevens gelet moet worden op een aantal kontrolevariabelen, waarvan vaststaat of redelijkerwijs kan worden a angenomen dat ze de gekozen cxiteriumvariabelen mede kunnen beinvloeden. In het ideale geval is het weliswar zo dat door randomisatie mogelijk storende faktoren worden uitgeschakeld, mar aangezien de te verwachten aantallen aan de lage kant zouden blijven, werd een kontrole toch nodig geacht.

De criteriumvariabelen kunnen nog worden ingedeeld naar:

- kenmerken betreffende de fysieke toestand,

- kenmerken betreffende de psychische toestand

- kenmerken betreffende de relatie met de partner

- kenmerken betreffende dagindeling en aktiviteiten.

De kontrolevariabelen betreffen een aantal faktoren van vó́r het infarct, met name de arbeidssituatie, klinische gegevens betreffende het infarct en de komplikaties in de CCU en de medikatie (voor een overzicht, zie bijlage 1).

Bij het onderzoek werden betrokken:

mannelijke patienten, jonger dan 65 jaar,

1. met een bewezen eexste of volgende infarct volgens WHOcriteria (1971),

2. afkomstig uit de CCU van het Academisch ziekenhuis Iue iden,

3. zonder contra-indikaties voor fysieke training en deeIname aan groepsgesprekken (bijlage 2).

4. die toesteming hadden gegeven tot deelname aan het onderzoek.

De toestemming tot deelname aan het onderzoek werd gevraagd vórrdat de randomisatie platsvond. Patiënten die vooraf te kennen gaven niet of juist wel in Katwijk gerevalideerd te willen worden, werden niet in het onderzoek betrokken. 
De patiênten uit de interventiegroep begonnen drie maanden na infarct aan de revalidatie. Dit is niet in overeenstemming met de huidige opvatting dat revalidatie zo snel mogelijk moet beginnen. In de tijd dat het onderzoek van start ging was men nog de mening toegedaan dat zware inspanning bif normal herstellende infarctpatienten pas geindiceerd was twee a drle maanden na infarct (Kellerman, 1977). Bovendien bestond bij de start van het onderzoek een wachtlijst voor Katwijk. Deze is weliswaar tijdens het onderzoek verdwenen, mar omdat voor alle patienten hetzelfde tijdschema diende te gelden, is de eerste meting en dus ook de start van de revalidatie op drie maanden na infarct gehandhaafd. 


\section{Beschrijving van de onderzoeksgroepen}

\subsection{Het Cargo-onderzoek}

Aan de oproep tot deelname aan het onderzoek gaven een kleine zeventig bedrijfsartsen gehoor, te zamen vertegenwoordigden zij 53 bedrijfsgeneeskundige diensten: 33 BGD's van afzonderlijke bedrijven, 14 gemeenschappelijke BGD's, 3 afdelingen bedrijfsgeneeskunde van Gemeentelijke GezondheidsDiensten en tenslotte 3 afdelingen van de Rijksgeneeskundige Dienst.

Van de in total 53 potentiële deelnemers, hebben elf niets ingestuurd, zes van de BGD's gekoppeld aan afzonderlijke bedrijven en vijf van de gekombineerde diensten. In totaal. werden de gegevens van 956 hartinfarctpatienten ingezonden, hiervan waren 43 als foutief te bestempelen (geen of dubleus infarct, niet binnen de onderzoekperiode, etc.) terwijl van vijfentwintig gevallen te veel gegevens ontbraken. Dit betekent dat de analyse kon worden uitgevoerd op 888 gevallen, dat is $93 \%$ van het ingezonden aantal. De netto-opbrengst kan zonder meer als hoog worden beschouwd. Voor alle duidelijkheid zij hier reeds opgemerkt, dat twee grote bedxijuen $51 \%$ van de in de analyse betrokken gevalien voor hun rekening nemen. Het ligt echter niet in de bedoeling per bedrijf de analyse te vervolgen.

Het gegeven dat elf van de potentiële deelnemers niets hebben ingestuurd betekent overigens naast het reeds genoemde, een nieuw selektieprobleem. Zo kan bij voorbeeld bij de 42 uiteindelijke deelnemers een goede administratieve ondersteuning (en aus een professionelere opzet) dan wel een grotere betrokkenhela blj het onderwerp van het onderzoek verondersteld worden.

Wij beschikken niet over gegevens om hier enige uitspraak over te doen. Het betekent wel een beperking ten aanzien van de waarde van algemene uitspraken uit dit onderzoek.

Van de onderzoekgroep ( $n=888$ ) blijken in totaal 208 patienten hetzij acuut, hetzij binnen een jaar na infarct te zijn overleden. De groep overledenen verschllt op drie punten duidelijk van de overlevenden de gemlddelde leeftijd ligt 1.5 jaar hoger, er komen meer recidieve infarcten en meer patiënten met veranderingen in de arbeidstaak om gezondheids redenen voor (Tabel 3.1 ). 
Tabel 3.1: Overledenen en overlevenden naar leeftijd, rangnummer infarct en veranderingen in de arbeidstaak.

\begin{tabular}{|c|c|c|c|}
\hline Kenmerk & $\begin{array}{l}\text { overledenen } \\
(n=208)\end{array}$ & $\begin{array}{l}\text { overlevenden } \\
\quad(n=680)\end{array}$ & \\
\hline $\begin{array}{ll}\text { leeftijd } & \bar{x} \\
& \text { s.d. }\end{array}$ & $\begin{array}{l}54.0 \\
(6.6)\end{array}$ & $\begin{array}{l}52.5 \\
(6.2)\end{array}$ & $\begin{aligned} t= & 3.10 \\
& p<.0\end{aligned}$ \\
\hline set recidief infarct & 18.4 & 9.3 & $\begin{array}{c}x^{2}=13.61 \\
d f=1 \\
p<.01\end{array}$ \\
\hline $\begin{array}{l}\text { q met veranderingen in } \\
\text { arbeidstaak }\end{array}$ & 20.2 & 7.8 & $\begin{array}{l}x^{2}=25.07 \\
d f=1\end{array}$ \\
\hline
\end{tabular}

Liggen de bevindingen uit deze tabel voor de hand, hetzelfde kan niet worden gezegd van de hoogte van het percentage overledenen. De letaliteit bedraagt 23\%, wat aan de lage kant is vergeleken met het landelijk cijfer van circa 35\% (van der Does en Lubsen, 1978).

Bij een nadere analyse per bedrijf of cluster bedrijven zijn de verschillen in letaliteit -de cijfers variêren van 2 tot $30 \%$ - in het oog lopend. Een laag percentage overledenen kan twee oorzaken hebben: de bedrijfsarts heeft niet alle overledenen aangemeld en/of het betrokken bedrijf heeft een naar verhouling jonge werknemers-populatie. Dit laatste zou ook moeten blijken uit het totaal ingestuurde infarcten, wat dan ook relatief laag zou moeten zijn. Voor een juiste beoordeling hiervan is dus meer informatie nodig over de population at risk.

Van een aantal bedrijven is de leeftijdsopbouw van het manne$1 \mathrm{ijk}$ personeel -peildatum 1 december 1977-bekend. Uit deze bedrijwen hebben we degenen gekozen die ook nog redelijke letaliteitcijfers te $z$ ien geven $(>25 \%)$, teneinde een subgroep te formeren, waarover komplete en redelijk betrouwbare informatie voorhanden is. Op hoofdpunten van de analyse zulle de totale resultaten steeds worden vergeleken met die uit dea subgroep. 
De subgroep betreft tien diensten, bij elkaar twaalf bedrijven casu quo bedrijfsvestigingen beslaand. Uit deze subgroep komen 570 infarctpatiënten, dit is 648 van het total. (Voor gedetailleerde informatie omtrent de subgroep zij men verwezen naar Diederiks, 1980).

Voor de subgroep kunnen nu uitspraken worden gedaan over de incidentie (alle eerste infarcten per 1000 per jaar) en de attack rate (totaal aantal infarcten per 1000 per jaar) in vergelijking met landelijke cijfers.

De 570 hartinfarcten in de subgroep komen voor ruim 99 uit de leeftijdsgroep 35 - 64 jaar, slechts vier treden op in de groep van 25 - 34 jaar. In tabel 3.2 wordt voor de leeftijdsgroep $35-64$ jaar een vergelijking gemaakt met landelijke cijfers (Commissie Coördinatie Onderzoek, Hart-en vaatziekten, TNO, 1980), betreffende de attack rate en de incidentie.

Tabel 3.2: Attack rate en incidentie in de subgroep naar leeftijd vergeleken met landelijke cijfers.

\begin{tabular}{|c|c|c|c|c|c|c|c|}
\hline \multirow{2}{*}{ leeftija } & \multirow{2}{*}{$\begin{array}{l}\text { populatie } \\
\text { at risk }\end{array}$} & \multirow{2}{*}{$\begin{array}{l}\text { totaal } \\
\text { Infarcten } \\
(2 \text { jaar) }\end{array}$} & \multirow{2}{*}{$\begin{array}{l}\text { eerste } \\
\text { infarct } \\
(2 \text { jaar })\end{array}$} & \multirow{2}{*}{$\frac{\text { attack }}{\text { sub- }}$} & \multirow{2}{*}{$\frac{\text { rate }}{\text { Iande- }}$} & \multicolumn{2}{|c|}{ incidentie } \\
\hline & & & & & & $\begin{array}{c}\text { sut- } \\
\text { groep }\end{array}$ & $\begin{array}{c}\text { lande- } \\
\text { lijk }\end{array}$ \\
\hline $35-44$ & 27.154 & 71 & 65 & 1.3 & 2.1 & 1.2 & 1.5 \\
\hline $45-54$ & 27.017 & 232 & 216 & 4.3 & 7.4 & 4.0 & 5.0 \\
\hline $55-64$ & $14: 988$ & 263 & 210 & 8.8 & 16.0 & 7.0 & 10.0 \\
\hline totaal & 69.159 & 566 & 491 & 4.1 & 6.0 & 3.5 & 5.0 \\
\hline
\end{tabular}

Incidentie en attack rate liggen in de subgroep lager dan de landelijke cijfers, vooral in de oudste leeftijdsgroep. Bovendien komen in de subgroep meer eerste infarcten voor: 87\% tegen landelijk circa 80 van het totaal aantal infarcten per jaar. Bij de vergelijking van onze cijfers met de landelijke moet in het oog worden gehouden dat, zeker in het geval van de attack rate, deze geschat $z i j n$ op basis van CBS-gegevens en van een aantal lokale epidemiologische studies. Nochtans is het redelijk te veronderstellen, dat de attack rate in de beroepsbevolking lager ligt dan in de totale bevolking, daar kan worden aangenomen dat een deel van de hart.. infarctpatienten zich in de WAO zullen bevinden. 
Een definitief antwoord op de vraag of alle infarcten die in de onderzoekperiode in de desbetreffende bedrijven zijn opgetreden in de subgroep terecht zijn gekomen, is dus niet te geven. Wel is duidelijk dat voor het overige deel van de onderzoekgroep geen uitspraak over incidentie en attack rate kan worden gedaan door het ontbreken van gegevens betreffende de personeelsopbouw.

De letaliteit in de subgroep bedraagt $28 \%$ en komt dus wat dichter bij het landelijk cijfer van $35 \%$ dan de letaliteit in de totale groep $(238)$. Dit betekent overigens dat de letaliteit in het overige deel van de onderzoekgroep circa $15 \%$ bedraagt, wat onwaarschijnlijk laag genoemd kan worden. Dit houdt in dat ten aanzien van de volledigheid van het materlaal voor dit deel in elk geval meer twijfels bestaan dan voor de subgroep. wanneer de subgroep op vier faktoren, te weten recidief of eerste infarct, angina pectoris, beroep en leeftijd, vergeleken wordt met de totale groep, blijken er slechts kleine verschillen te bestaan.

In de subgroep komen naar verhouding lets meer recidieve infarcten voor en iets minder angina pectoris. Naar beroep en leeftijd zijn de verschillen miniem (Diederiks, 1980). In tabel 3.3 is een globaal overzicht gegeven over de samenstelling van de totale groep, subgroep en restgroep naar overlijden en overleven.

Tabel 3.3: Beschrijving van totale groep, subgroep en restgroep.

\begin{tabular}{|c|c|c|c|c|c|c|c|}
\hline \multirow{3}{*}{ Kennerken } & & \multicolumn{2}{|c|}{ subgroep } & \multicolumn{2}{|c|}{ restgroep } & \multicolumn{2}{|c|}{ totale groep } \\
\hline & & -- & --- & - & -- & $-\infty$ & \\
\hline & & 8 & $(n)$ & 政 & $(\mathrm{n})$ & 8 & $(n)$ \\
\hline \multirow[t]{3}{*}{ overleden: } & acuut & 67 & $(106)$ & 55 & $(27)$ & 64 & (133) \\
\hline & in ziekenhuis & 23 & $(37)$ & 35 & $(17)$ & 26 & 154 \\
\hline & na ontslag & 10 & $(16)$ & -10 & (5) & 10 & 21 \\
\hline & & & $\downarrow$ & & $\downarrow$ & & $\downarrow$ \\
\hline \multirow{2}{*}{\multicolumn{2}{|c|}{$\begin{array}{l}\text { total overledenen } \\
\text { total overlevenden }\end{array}$}} & 28 & (159) & 15 & (49) & 23 & (208) \\
\hline & & 72 & $(411)$ & 85 & (269) & 77 & $(680)$ \\
\hline
\end{tabular}


In de restgroep blijken relatief minder acuut overledenen en relatief meer overledenen in het ziekenhuis aanwezig te zijn. Dit is niet geheel konsistent met de veronderstelling dat de bedrijfsartsen van de restgxoepbedrijven een algehele onderrapportage van de vroeg overledenen te verwijten zou zijn. Niettemin is de letaliteit in deze groep (15\%), zoals gezegd, onwaarschijnlijk lamg. In de subgroep is de verdeling binnen de overledenen: acuut overleden, in ziekenhuis en na ontslag overleden, in overeenstemming met die in de totale groep. Daar elders al is gerapporteera (Diederiks, 1980), dat de analyse op hoofdpunten voor totale groep en subgroep, vrijwel dezelfde resultaten lat zien, zal hier volstaan worden met het vermelden van de resultaten van de totale groep.

\subsection{Het Leidse onderzoek}

\section{Uitgangspopulatie}

In hoofdstuk 2.3, opzet van het Leidse onderzoek, is al een beschrijving gegeven van de kenmerken van de patiënten die voor het onderzoek in aanmerking kwamen. De eerste optimistische verwachtingen waren, dat in circa fén jaar zo'n 100 patiënten uit de CCu-populatie geworven zouden kunnen worden. Rekening houdend met de uitval zouden dan revalidatie- en kontrolegroep elk uit veertig patienten kunnen bestaan. Deze verwachtingen bleken op twee punten te optimistisch. Ten eexste ten aanzien van de periode, maar ook ten aanzien van de antallen. De uiteindelijke 'wervingsperiode' heeft geduurd van juli 1974 tot en met december 1976. In die periode werden 146 patienten aangeboden voor het ondexzoek. Hiervan konden er 73 worden toegewezen a an revalidatieof kontrolegroep. In schema 1 vindt men een rekonstruktie van de totstandkoming van de ulteindelijk ingederlde patientengroep. Allereerst moet de aandacht gevestigd worden op de 88 patienten, die ten onrechte niet werden aangeboden. De redenen voor het niet aanbieden zijn tweéerlei: om te beginnen waren er nog wel eens kommunikatiestoornissen tussen ziekenhuisorganisatie en projekt. Verder valt op dat in deze groep naar verhouding meer patienten met contraindikaties voorkomen dan in de 146 wel aangeboden patienten (namelijk 56\% tegen 25\%). Dit dulat erop dat deze groep een negatieve selektie is uit de ccu-populatie. Van de 88 patien- 


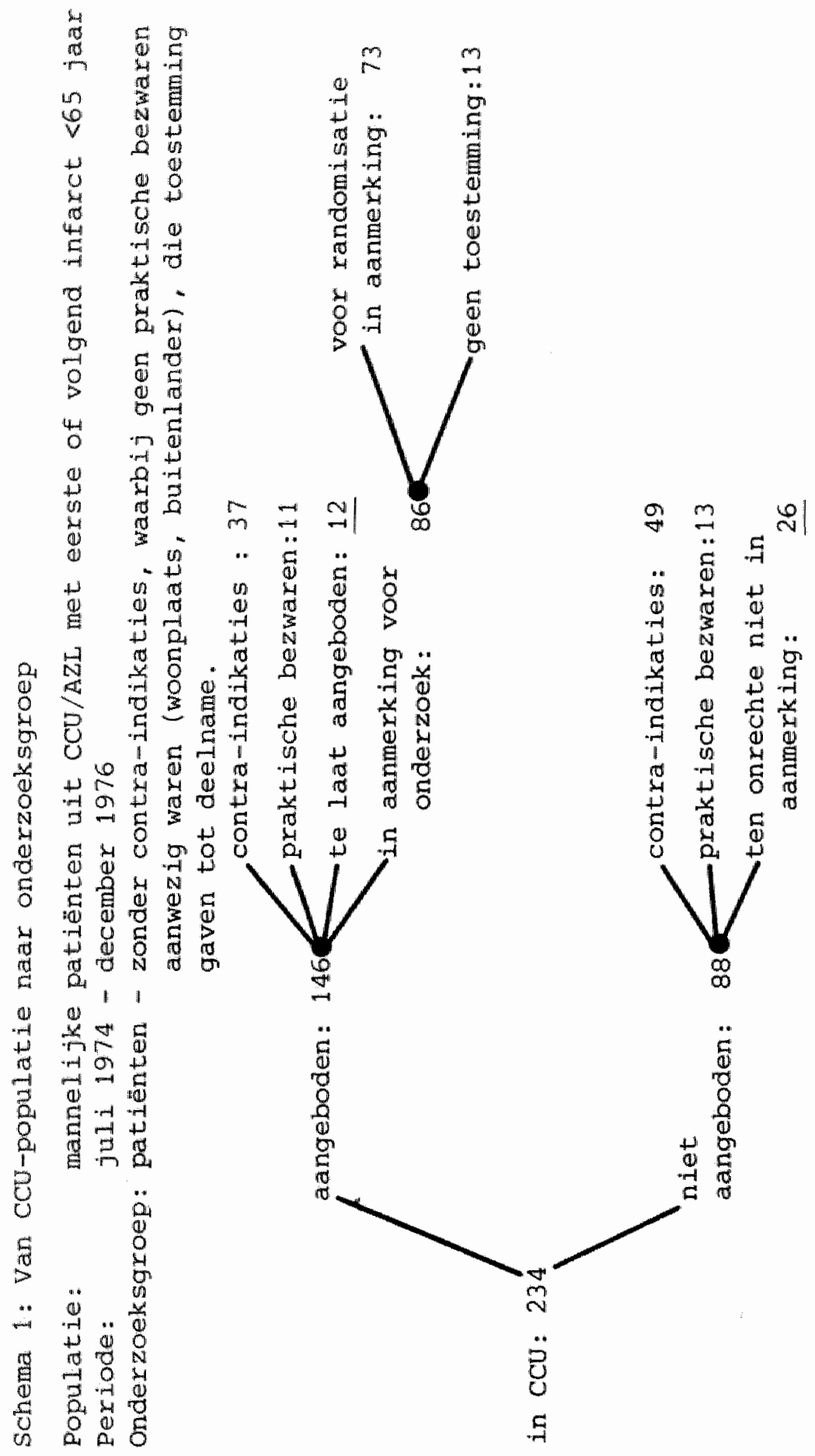


ten hadden 26 wel in aanmerking kumen komen voor het onderzoek, 20 van hen waren patienten met een hoog beroep. Aange$z$ ien deze patiënten op andere faktoren vergelijkbaar waren met de 86 die normal in aanmerking kwamen, duidt dit weer op een positieve selektie. Het blijkt dus dat twee selektiemechanismen een rol hebben gespeeld bij de niet-aanbieding van 88 patiênten. Samen met de 12 patiënten die te laat werden aangeboden zijn er 38 patiënten ten onrechte niet voor het onderzoek in aanmerking gekomen.

In bijlage 3 is een overzicht gegeven van de ccu-populatie, de angeboden groep, de ingedeelde en de ten onrechte niet voor het onderzoek in aanmerking gekomen groep op de variabelen leeftijd, beroep, arbeidssituatie vór infarct, grootte van het infarct en het vofrkomen van een recidief infarct. De voor het onderzoek aangeboden groep blijkt op deze variabelen redelijk overen te komen met de cCU-populatie, terwijl de ingedeelde groep een gunstiger beeld vertoont in vergelijking met die populatie: minder recidieve infarcten, minder grote infarcten en relatief meer patienten opgenomen in het arbeidsproces. Dit is met name het gevolg van de gehanteerde contra-indikaties. De groep die ten onrechte niet voor het onderzoek in aanmerking kwam bevatte, zoals gezegd, relatief veel patiënten met een hoog beroep en naar verhouding mincer patiënten met een recidief infarct, wanneer we deze vergelijken met zowel de aangeboden als de ingedeelde groep. Bowenstaande opmerkingen kunnen alle betrokken worden op de externe validiteit van het onderzoek. Bij externe validitelt gaat het om de generaliseerbaarheid van de resultaten van het anderzoek. Een konklusie die het bovenstaande zeker toelaat, is dat de uiteindelijke onderzoeksgroep op bepaalde punten ongunstiger is dan gegeven het onderzoeksprotokol en de CCU-populatie kon worden verwacht. De uitspraken die het onderzoek oplevert, heblen in principe betrekking op patiënten met kenmerken zoals die gespecificeerd zijn voor de ingedeelde groep, mits geen specifieke uitvalefiekten optreden.

\section{Uitval en uiteindelijke onderzoeksgroep}

Uitval uit de ingedeelde groep kan op twee manieren de konklusies aantasten. Bij een selektleve uitval in revalidatieén kontrolegroep zou de externe validiteit worden aangetast. 
Wanneer in de revalidatiegroep een andere uitval zou optreden als in de kontrolegroep en omgekeerd, zou de interne validiteit worden aangetast. De twee groepen zouden dan immers niet meer vergelijkbaar kunnen worden. In tabel 3.1 is weergegeven hoe het verloop is geweest in revalidatieen kontrolegroep. Het blijkt dat uiteindelijk 51 van de 73 oorspronkelijk ingedeelde patiënten het gehele onderzoek hebben ondergaan. Dit komt neer op een uitval van $30 \%$.

Tabel 3.4: Het verloop in de ingedeelde groep

\begin{tabular}{lcccccc}
\hline Maanden na MI: & bij randomisatie & 3 & 6 & 12 & 24 \\
\hline revalidatie & 36 & 30 & 28 & 27 & 24 \\
kontrole & 37 & 32 & 31 & 28 & 27 \\
\hline totaal & 73 & 62 & 59 & 55 & 51 \\
\hline
\end{tabular}

De uitval in de revalidatiegroep is wat groter dan in de kontrolegroep: 33 tegen 278. Dit verschil is echter niet signifikant (hypergeometrische verdeling: $\mathrm{p}=.17$ ). De redenen voor de uitval vindt men in tabel 3.5 .

Tabel 3.5: Redenen van uitval in revalidatie- en kontrolegroep

revalidatiegroep kontrolegroep

\begin{tabular}{lcc} 
overlijden & 2 & 1 \\
medische gronden & 5 & 1 \\
psycho-sociale gronden & 2 & 1 \\
wil niet meer & 2 & 2 \\
verhuisd & 1 & 2 \\
wil gaan revalideren & - & 3 \\
\hline total & 12 & 10 \\
\hline
\end{tabular}


In de revalidatiegroep 1 ijkt dus meer uitval op medische gronden op te treden. Getoetst binnen de groep uitvallers is het verschil tussen revalidatie- en kontrolegroep echter niet signifikant op dit punt $(p=.11)$.

De verdere analyse van de resultaten zullen gebaseerd zijn op de 51 patiënten die het gehele onderzoek hebben ondergaan. Het is dan van belang na te gaan of de uitval de vergelijkbaarheid van beide groepen negatief heeft beinvloed en of de uitvallers specifieke kenmerken hebben in vergelijking met de oorspronkelijk ingedeelde groep. Om deze vragen te kunnen beantwoorden zijn 15 variabelen geanalyseerd op deze effekten (zie bijlage 4). Als voorbeelden worden hier de analyses gegeven voor leeftijd en recidief infarct.

Tabel 3.6: Variantie-analyse onderzoeksgroep: uitval met betrekking tot leeftijd

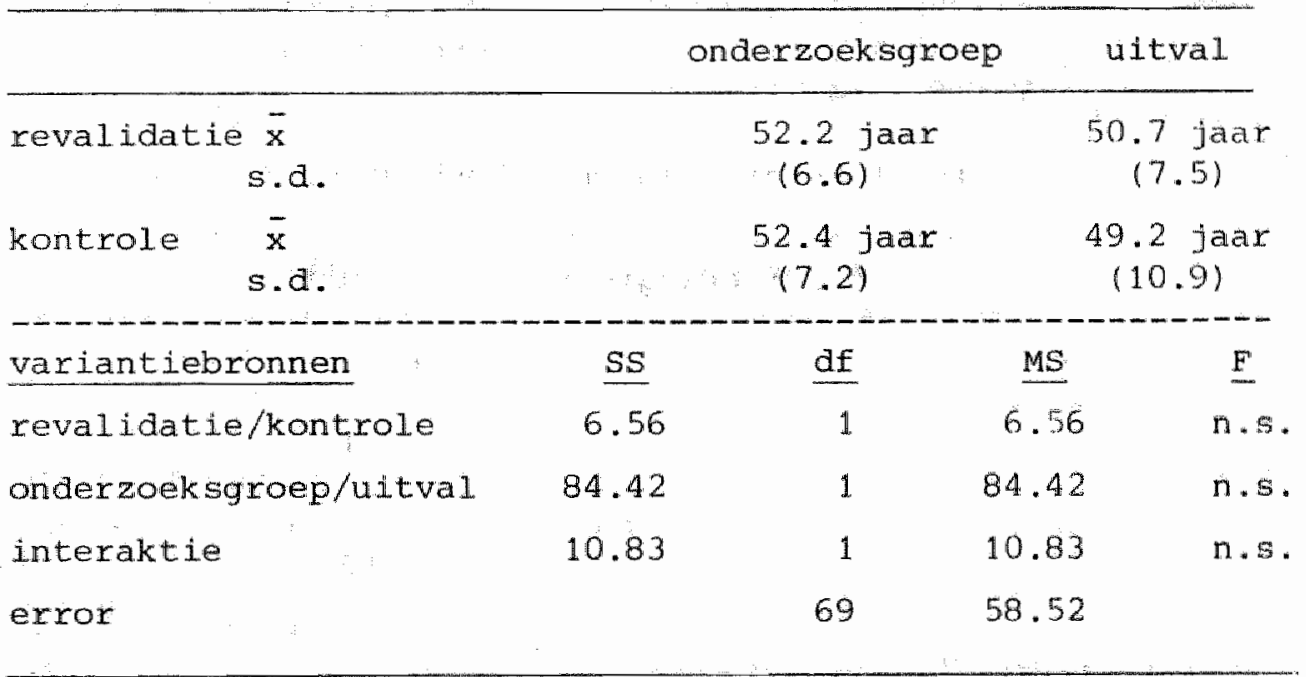

Deze analyse, gesuggereerd door Jurs en Glass (1971) en hier uitgevoerd als een variantie-analyse met ongewogen gemiddelden (Winer, 1971) kan de volgende resultaten opleveren. Bij een signifikant hoofdeffekt, van revalidatie/kontrolegroep zijn beide groepen niet vergelijkbaar op de onderzochte variabele. Bij een signifikante interaktie is sprake van een verschil 
in uitval tussen revalidatie- en kontrolegroep.

Ten aanzien van de variabele leeftijd lijkt op basis van de gemiddelden sprake te zijn van een specifieke uitval: de uitvallers zijn gemiddeld jonger dan de patiënten in de onderzoeksgroep. De variantie-analyse laat zien dat dit effekt niet signifikant is. Op dezelfde wijze zijn analyses uitgevoerd op de volgende variabelen: aktiviteitsgetal voor infarct, Watt-max, subjektieve belasting, T-score van de $A B V$ en de perceived exercise tolerance, allen gemeten op drie maanden na infarct.*) slechts in én geval is sprake van een noemenswaardig effekt: de uitvallers zijn gemiddeld minder lichamelijk aktief voor het infarct dan de patienten uit de onderzoeksgroep $(p<.10)$.

Hoewel statistisch niet aantoonbaar, lijken de uitvallers voorts een wat lager maximaal prestatievermogen en een hogere T-score (dat wil zeggen een defensievere houding bij het invullen van de psychologische tests) te hebben. voor de niet-metrische variabelen is de analyse uitgevoerd met behulp van de $X^{2}$. Als voorbeeld geven we hier de analyse voor recidief infarct.

Tabel 3.7: Recidief infarct in onderzoeksgroep en uitval

onderzoeksgroep

recidief infarct: revall. kontr. reval. kontr.

recidief infarct: revall. kontr. reval. kontr.

\begin{tabular}{lrrrrr}
\hline Ja & 4 & 1 & 1 & 0 & 6 \\
neen & 20 & 26 & 11 & 10 & 67 \\
\hline & 24 & 27 & 12 & 10 & 73 \\
\hline
\end{tabular}

$X_{\mathrm{L}}^{2}=4.74, \mathrm{df}=4, \mathrm{n} \cdot \mathrm{s}$.

De toetsing is uitgevoerd onder de hypotese dat de drie varia belen onderling onathankelijk zijn. De berekening is uitgevoe met behulp van het likelihood ratio-criterium, daar dit in he algemeen te preferen valt boven de "gewone" $X^{2}$ (Everitt, 1977

*) De precieze beschrijving van deze variabelen zal worden gegeven bij de presentatie van de resultaten. 
De hypotese van de onderlinge onafhankelijkheid blijkt ten aanzien van de faktor recidief infarct te kunnen worden gehandhaafd: Hetzelfae geldt voor: beroep, angina pectoris ến maand na infarct, $\beta$-blokkers bij ontslag, angina pectoris vór infarct, hypertensie vór infarct, grootte van infarct en het al of niet voorgeschreven krijgen van antiaritmica bij ontslag en het al of niet optreden van komplikaties in de ccu (zie bijlage 4 ).

De konklusie van bovengenoemde analyses is dan dat voor de vijftien onderzochte variabelen geen sprake is van uitvaleffekten. De interne validiteit van het onderzoek is dus niet aangetast door de uitval. De externe valiaiteit is dat ook niet, mar is, zoals gezegd, problematisch doordat van een specifieke populatie werd uitgegaan. Het is dan wel zaak zoveel mogelijk externe informatie te benutten aan de hand warran kan worden vastgesteld in hoeverre de onderzoeksgroep afwijkt van andere groepen infarctpatiënten. De vergelijkbaarheid van de revalidatie-en kontrolegroep lijkt door bovenstaande analyses eveneens gewaarborgd. Toch zijn er een aantal vermeldenswardige, zij het niet signifikante verschilien. Zo bevinden zich in de revalidatiegroep meer patienten met een recidief infarct (vier tegen een) en, warschijniljk aaarmee samenhangend, meer patiënten met angina pectoris vóor infarct (zeven tegen drie) dan in de kontrolegroep. Omgekeerd bevinden zich in de kontrolegroep meer patiënten met hypertensie in de anamnese (zes tegen twee) en meer patiënten die bij ontslag anti-aritmica (tien tegen viff) kregen voorgeschreven dan in de revalldatiegroep. Tenslotte is het maximal prestatievermogen in de revalidatiegroep 3 manden na infarct lager 1146 tegen 158 watt) dar in de kontrolegroep.

Als belangrijkste externe referentie zal gebruik worden gemaakt van een met de revalidatiegroep vergelijkbare groep, die geselekteerd is uit in 1973 te katwijk gerevaIideerde infarctpatienten. Uit de beschikbare 125 cases zijn middels frekwentieverdeling-kontrole op beroep. angina pectoris en leeftija, 24 patiènten gekozen, die twee à drie maanden na infarct gingen revalideren. De vergelijkingsgroep van 24 patiënten is uiteraard vergelijkbaax met de revalidatiegroep uit het onderzoek op de faktoren die middels de frekwentieverdeling-kontrole wexden 
gelijkgeschakeld.

op andere faktoren, met name recidief infarct en medikatie ( $B$-blokkers drie maanden na infarct) blijkt de vergelijkingsgroep zich gunstig te onderscheiden van de revalidatiegroep (zie bijlage 5).

3.3 Metodische opmexkingen

statistische signifikantie hangt samen met het aantal eenheden waarop de toetsing is uitgevoerd. Een gevolg hiervan is dat bij kleine aantallen mogelijke verschillen over het hoofd worden gezien, terwijl omgekeerd blj grote aantallen op grond van toetsing aan ook kleine verschillen, betekenis wordt toegekend. Dit probleem is, impliciet, ook in het voorafgaande aan de orde geweest. Zo werd aan een verschil in gemiddelde leeftijd van twee jaar in het Leidse onderzoek geen betekenis toegekend, terwijl hetzelfde verschil in het CARGO-onderzoek signifikant werd bevonden. Statistische signifikantie mag dan ook nooit als enig criterium worden aangewend om tot uitspraken te komen. Daar waar dat van pas kont zal ook de sterkte van een mogelijke relatie aan de orde moeten worden gesteld. Het belangrijkste is echter dat men een verschil of relatie allereerst moet beschouwen vanuit een gezichtspunt van teoretische relevantie. Met het oog hierop werd nader ingegaan op de kenmerken van de uitvallers, die, hoewel statistisch niet aantoonbaar, toch de indruk gaven dat het wellicht on een negatieve selektie ging. 


\section{Werkhervatting als objektief herstel; Resultaten van het cargo-onderzoek}

\subsection{Inleiding}

In hoofdstuk 1 is reeds uitvoerig ingegaan op de prominente plaats van werkhervatting als objektleve mat van herstel na hartinfarct. Deze mat heeft in elk geval een aantal aantrekkelijke kanten: $z i j$ is ondubbelzinnig vast te stellen, valt samen met wat maatschappelijk gezien wordt als herstel en impliceert tot op zekere hoogte fysiek en psychisch herstel. Nadelen van deze mat zijn het globale karakter en de gevoelighela voor veranderingen in de soclaalekonomische omstandigheden.

Gezien het feit, dat landelijke cijfers omtrent werkhervatting na hartinfarct tot nog toe ontbraken, zal eerst. een behandeling in hoofdiljnen plaatsvinden. Daarna zal worden ingegaan op de faktoren die werkhervatting beinvloeden. De mogelijke rol van revalidatie staat hierbij centraal. Het tweede deel van het hoofdstuk zal handelen over het sukses van hervatting, met name zal het hier gaan over het zlekteverzuim na de hervatting. In het volgende hoofdstuk zal worden ingegaan op de subjektieve oordelen van arts en patiënt omtrent hervatting.

\subsection{Werkhervatting na hartinfarct in hoofdiijnen}

zoals in hoofdstuk 3 is gemeid werden door 42 bedrijfsgeneeskundige diensten van 888 te analyseren gevallen de gegevens geleverd. Schema 2 geeft een globaal overzicht van de hoofdresultaten. Van de totale populatie van mannelijke haxtinfarctpatienten, komt ulteindelijk $28 \%$ geheel en $22 \%$ gedeeltel1jk aan het werk. Onder gehele hervatting wordt verstaan een terugkeer tot werk dan meer dan driekwart van een vollealge werkdag beslaat.

Van de 680 overlevenden van de totale groep hervatten in eerste instantie 452 mannen het werk, dit is $66,58,22$ mannen gingen -meestal vervroegd- met pensioen. zij vormen een aparte groep met een hoge gemidalda leeftija (63 jaar) en zullen in de verdere beschouwingen niet voorkomen. 
Schema 2: Beschrijving van de onderzoeksgroep op de hoofdresultaten*)

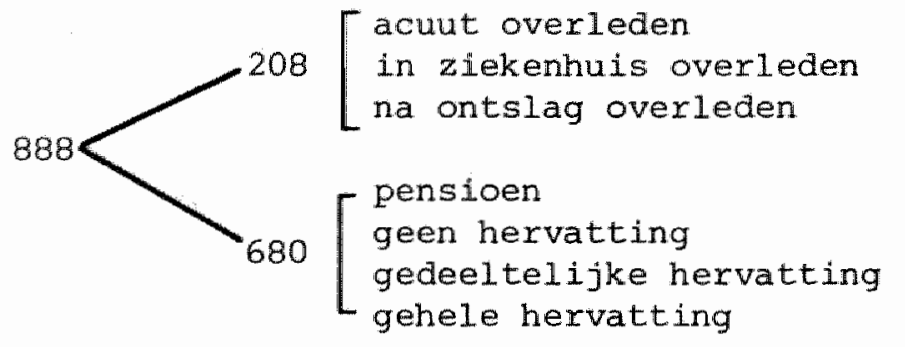

\begin{tabular}{rr}
\multicolumn{1}{c}{$\mathbf{n}$} & \multicolumn{1}{c}{8} \\
133 & 15.0 \\
54 & 6.1 \\
21 & 2.4 \\
& \\
22 & 2.5 \\
214 & 24.1 \\
195 & 22.0 \\
249 & 28.0
\end{tabular}

*) In dit schema is uitgegaan van de toestand zes maanden na hervatting en twalf maanden na datum infarct voor de niet-hervatters.

Ex zijn in een periode zes maanden na hervatting nog acht definitieve uitvallers (geklassificeerd als niet hervat) te betreuren, zodat het netto-percentage hervatters 65.3 bedraagt, 67.58 zonder de gepensioneerden in de percentagebasis te betrekken. Dit overall-percentage ligt tussen de grenzen die getrokken kunnen worden op basis van enkele lokale cijfers: Lie et al. (1975): 57\%; Vermeulen et al. (1978): 71\% en Erdman (1979): 64\%.

Ter vergelijking werd door ons een schatting gemaakt van het percentage hervatters onder infarctpatiënten die WAOverzekerden waren. Het aantal WAO-verzekerde mannen in de leeftijd van 35 - 64 jaar bedroeg 1.914 .495 (GMD-jaarverslag, 1976). Uitgaande van een incidentie van het hartinfarct van 5 per 1000 zouden zo'n 9600 infarcten in deze groep verwacht kunnen worden. Met een letaliteit van 35\% kunnen dan ongeveer 6200 overlevenden verwacht worden. Op grond van gegevens van de Raad voor GezondheidsxesearchTNO en het CBS (1980) stonden in 1976 ongeveer 2900 mannelijke hartinfarctpatiënten in de WAO-statistiek geboekt als herstellend van een, in dat jaar opgetreden, hartinfarct. Met andere woorden, ongeveer 3300 van de 6200 overlevende hartinfarctpatienten zullen vermoedelijk het werk hebben hervat. Dit komt neer op een hervattingspercentage van 53․ Hoewel aan deze schatting de nodige onzekerheden kleven, kan toch worden opgemerkt, dat dit percentage laag is, zowel in vergelijking met de genoemde lokale onderzoeken 
als met het resultaat van dit onderzoek. Dit oordeel vindt zeker ook enige steun in het resultaat van het onderzoek van oostenbrink (1971), die, eveneens voor wAO-verzekerde hartinfarctpatiënten tot een hervattingspercentage van 56 kwam. Het ligt voor de hand een zekere ontwikkeling te verwachten in de mate van hervatting. Zo is het aannemelijk dat het merendeel van de patienten eerst gedeeltelijk zal hervatten. In tabel $4.1 \mathrm{vindt}$ men de ontwikkeling in de mate van hervatting tot en met zes maanden na hervatting.

Tabel 4.1: Mate van hervatting $0-3-6$ maanden na datum hervatting (CARGO-onderzoek).

\begin{tabular}{lccc}
\hline hervatting & 0 & 3 & 6 mnd \\
\hline gedeeltelijk & $93.0 \%$ & 64.98 & 43.98 \\
geheel & $7.0 \%$ & 35.18 & 56.18 \\
& $(444)$ & $(444)$ & $(444)$ \\
\hline
\end{tabular}

Volledige werkhervatting blijkt dus te verlopen via gedeeltelijke hervatting, al brengt een naar verhouding groot deel der patiënten het niet verder dan een gedeeltelijke hervatting. Het percentage van de overlevenden dat uiteindelijk het werk geheel heeft hervat, bedraag 36.6 en dat het werk gedeeltelijk heeft hervat $28.7 \%$.

Tabel 4.2: Gehele of gedeeltelijke hervatting in eigen of ander werk (CARGO-onderzoek).

\begin{tabular}{lccc}
\hline & eigen werk & $\begin{array}{l}\text { aangepast ei- } \\
\text { gen of ander }\end{array}$ & total \\
\hline gehele hervatting & 74.78 & 25.38 & 56.18 \\
& $(186)$ & $(63)$ & $(249)$ \\
gedeeltelijke hervatting & 57.48 & 42.68 & 43.98 \\
& $(112)$ & $(83)$ & $(195)$ \\
totaal & 67.18 & 32.98 & 100.08 \\
& $(298)$ & $(146)$ & $(444)$ \\
\hline
\end{tabular}

$\mathrm{X}_{\mathrm{L}}^{2}=14.73, \mathrm{df}=1, \mathrm{p}<.01, \varphi=.182$ 
Naast gehele of gedeeltelijke hervating, geeft de terugkeer naar eigen dan wel ander werk een nadere kwalifikatie aan de hervatting. Het blijkt dat gehele hervatting voor $3 / 4$ plaats vindt in het eigen werk, terwijl gedeeltelijke hervatting voor bijna de helft van de gevallen in aangepast eigen, dan wel ander werk plaats vindt (tabel 4.2).

Over het geheel genomen keert tweederde van de hervatters terug in het eigen werk. De bovengenoemde percentages hebben betrekking op de groep hervatters. Voor een goed beeld van de hervatting over de hele onderzoeksgroep moet uitgegaan worden van een uitsplitsing van het overall-percentage hervatting (schema 3 ).

Schema 3: Gehele of gedeeltelijke hervatting in eigen of ander werk in de groep overlevenden

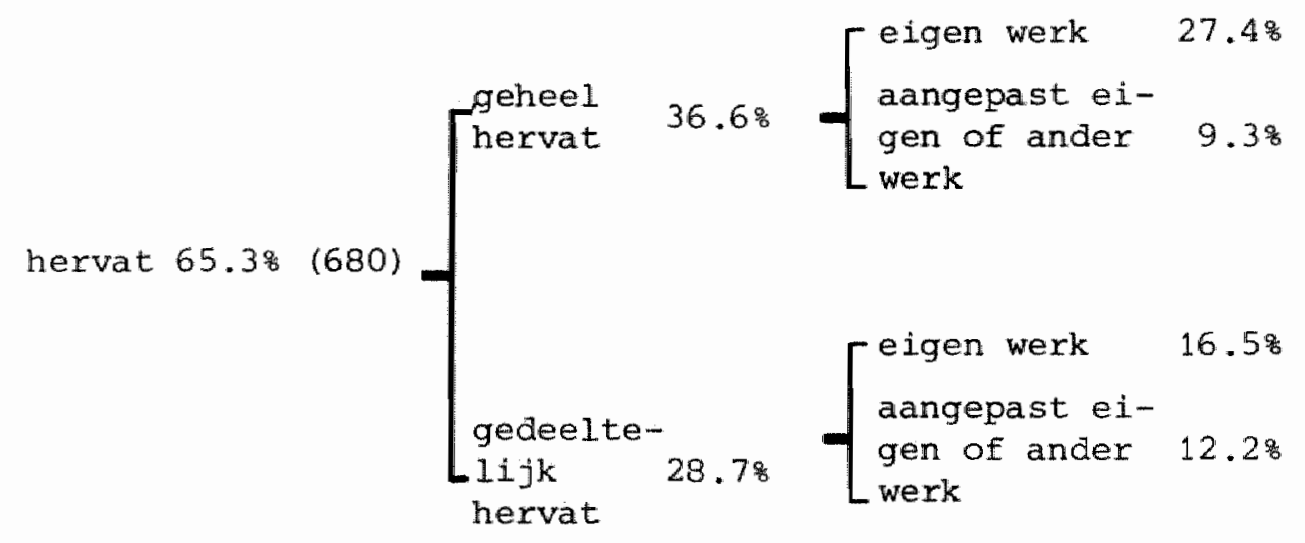

Als men gehele terugkeer in het eigen werk als volledig herstel wenst te beschouwen, dan is duidelijk dat slechts ongeveer $27 \%$ van de overlevenden in deze betekenis volledig hersteld is.

In het algemeen kan worden aangenomen dat naarmate de ziektewetperiode voortschrijdt, de kans op herintreding kleiner wordt. Een analyse van het interval infarct - hervatting ligt dus voor de hand (tabel 4.3) 
Tabel 4.3: Interval infarct - hervatting (CARGO-onderzoek)

\begin{tabular}{lcc}
\hline interval: & $\begin{array}{c}\text { totale groep } \\
\text { cumulatief }\end{array}$ & $\begin{array}{l}\text { uiteindelijke hervat- } \\
\text { ters cumulatiof }\end{array}$ \\
\cline { 2 - 3 }$<3$ mnd. & 16.7 & 24.8 \\
$\leqslant 6$ mad. & 51.2 & 75.9 \\
$\leqslant 12$ mad. & 67.5 & 100.0 \\
& $(658)$ & $(444)$
\end{tabular}

Het blijkt dat binnen een half jaar na infarct de helft van de mannen weer aan het werk is, hetgeen neerkomt op ruim drievierde van de groep die uiteindelijk het werk hervat. De kans op hervatting is dus het grootst in het eerste half jaar na infarct, daarna is die kans kleiner, maar beslist niet te verwaarlozen. Bij nadere analyse blijkt dat gehele hervatting eerder plaats vindt dan gedeeltelijke; hervatting in eigen werk lijkt ook samen te gaan met een snellere hervatting, maar dit is statistisch niet van betekenis (tabel 4.4)

Tabel 4.4: 8 van de hervatters dat $<6$ maanden na infarct hervat naar eigen/ander en gehele/gedeeltelijke hervatting (CARGO-onderzoek)

\begin{tabular}{lccc}
\hline & eigen werk & $\begin{array}{l}\text { aangepast eigen } \\
\text { of ander werk }\end{array}$ & totaal \\
\cline { 2 - 4 } gehele hervatting & $81.2 \%$ & 87.38 & $82.7 \%$ \\
& $(186)$ & $(63)$ & $(249)$ \\
gedeeltelijke & $72.3 \%$ & 60.28 & 67.28 \\
hervatting & $(112)$ & $(83)$ & $(195)$ \\
\hline total & 77.98 & 71.98 & $75.9 \%$ \\
& $(298)$ & $(146)$ & $(444)$
\end{tabular}

Uit tabel 4.4 blijkt voorts dat het grootste verschil in snelheid van hervatting bestaat tussen gehele en gedeeltelijke hervatting in eigen werk. Deze bevinding ligt niet 
geheel voor de hand, men zou verwachten dat de kombinatie geheel/eigen het gunstigst en de kombinatie gedeeltelijk/ ander het ongunstigst zou uitvallen. Wellicht is het hoge percentage dat hervat binnen zes maanden in de kategorie geheel/ander terug te voeren op specifieke kenmerken, zoals motivatie, van de betreffende groep.

\subsection{Faktoren die samenhangen met hervatting}

Leeftija, beroep, angina pectoris

In hoofdstuk 1 is reeds melding gemaakt van de overeenstemming die in de Iiteratuur bestaat over de invloed van leeftijd, beroep en tot op zekere hoagte ook van de ernst van het infarct op werkhervatting.

Beroep is in de genoemde onderzoeken meestal opgevat als een indikator voor sociale status, terwijl de ernst afwisselend wordt geoperationaliseerd als: aan- of afwezigheid van angina pectoris en/of andere cardiale komplikaties, grootte van het infarct, of een of andere index voor de ernst van het infarct. Tenslotte kan ook het recidief infarct beschouwd worden als ernstindikator.

In dit onderzoek zijn de volgende variabelen opgenomen: de leeftijdis die ten tijde van het infarct. Beroep is geoperationaliseerd als beroepsniveau volgens ITS-kode. Daarnaast is de belasting in de arbeidstaak voor het infarct, geschat door de bedrijfsarts naar energetische, perceptief-mentale en psycho-sociale belasting, in het onderzoek opgenomen.

De ernst van de aandoening is hier benaderd door de infarcten te klassificeren met behulp van de aan- of afwezigheid van angina pectoris, de aan- of afwezigheid van cardiale komplikaties (aneurysma, ritmestoornissen e.d.) voor de toestand circa drie manden na infarct. Tenslotte is gebruik gemaakt van het gegeven of al of niet sprake was van een recidief infarct (voor frekwentieverdelingen zie bijlage 6)

Daax angina pectoris in vergelijking met komplikaties en recidief infarct in de groep overlevenden het meest voorkomt (respektievelijk 44, 13 en 98), zal de analyse in eerste instantie ondernomen worden voor leeftijd, beroepsniveau en angina pectoris. Ten behoeve van de eenvoud zal in het algemeen in dit stadium van de analyse gewerkt wor. den met de volgende dichotomieën: leeftijd: $<55,>55$, angi- 
AP-, APt, en beroep: hoog (hogere bexoepen en middelbare employees), Iaag (ongeschoolde handarbeld, geschoolde handarbeid en lagere employees).

Wanneer de afzonderlijke effekten van leeftijd, beroep en angina pectoris op de hervatting worden bezien, lijkt de grootte van die effekten van dezelfde orde te zijn (fig. 2 ).

Figuur 2: Percentage hervatters naar leeftija, angina poctoris en beroep (CARGo-onderzoek)

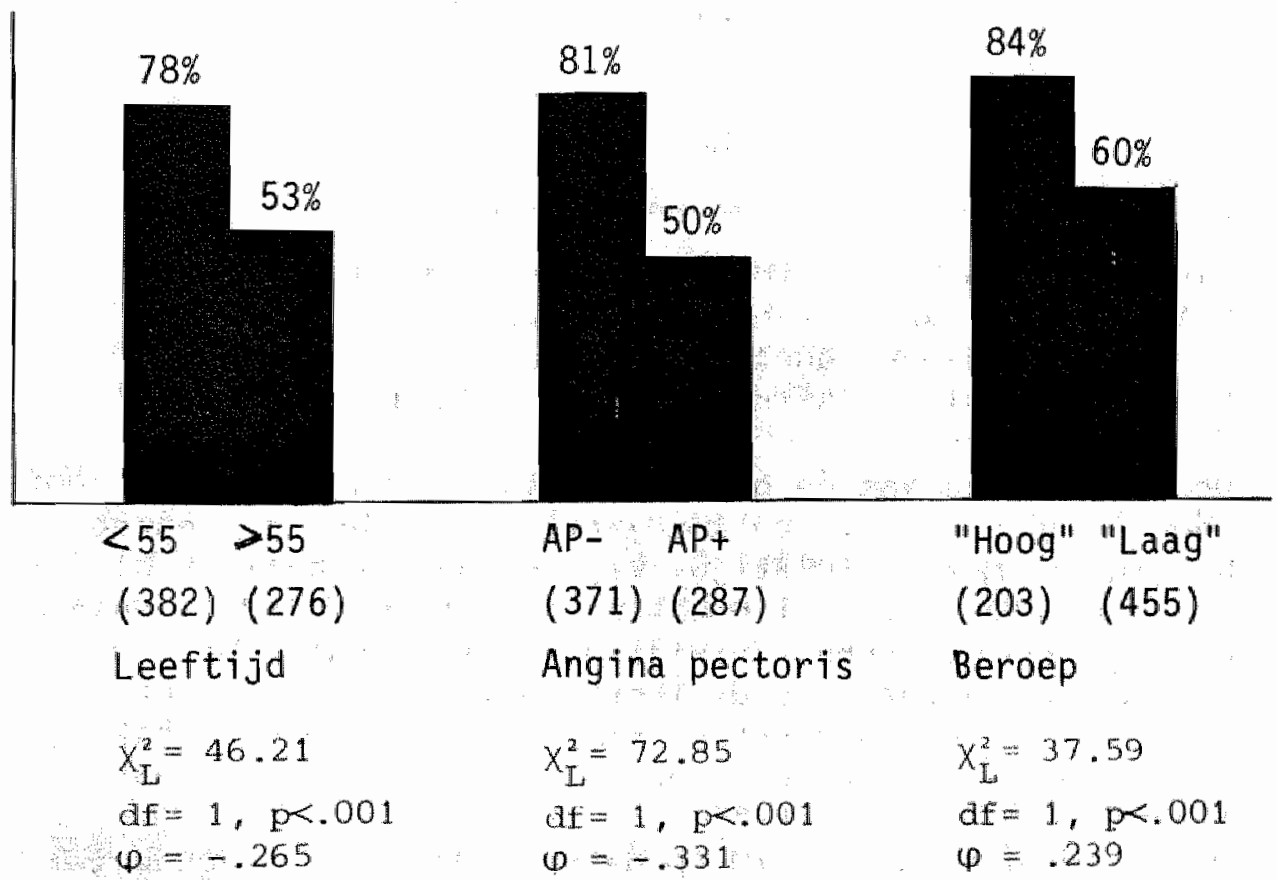

De drie faktoren spelen alle de hun toebedachte rol: de afwezigheid van angineuze klachten, een leeftijd beneden de 55 jaar en een hoog beroep hebben een signifikant gunstig effekt op het hervattingspercentage. Met de faktoren leeftijd, beroep en angina pectoris te zamen ontstaan aanzienlijke verschillen in de hervattingspercentages (tabel. 4.5). In overeenstemming met de verwachting gebaseerd op figuur 1 is de kombinatie: hoog, $A P-,<55$ jaar het gunstigst en de kombinatie: laag, APt, 255 jaar het ongunstigst. 
Tabel 4.5: Werkhervatting naar leeftljd, beroep en angina pectoris (AP) (CARGO-onderzoek)

\begin{tabular}{lccccc}
\hline & & \multicolumn{4}{c}{ hervatting } \\
\cline { 3 - 6 } AP & leeftija & $\begin{array}{c}\text { 'hoge' } \\
8\end{array}$ & $\begin{array}{c}\text { beroepen } \\
(\mathrm{n})\end{array}$ & $\begin{array}{c}\text { 'lage } \\
\%\end{array}$ & $\begin{array}{c}\text { beroepen } \\
(\mathrm{n})\end{array}$ \\
\hline AP- & $<55$ & 97 & $(88)$ & 86 & $(146)$ \\
$\mathrm{AP}+$ & $<55$ & 81 & $(31)$ & 54 & $(117)$ \\
$\mathrm{AP}-$ & $>55$ & 76 & $(55)$ & 60 & $(82)$ \\
$\mathrm{AP}+$ & $>55$ & 66 & $(29)$ & 33 & $(110)$ \\
\hline
\end{tabular}

Uit tabel 4.5 blijkt voorts dat de drie faktoren onafhankelijk van elkaar het hervattingspercentage beinvloeden, al lijkt de aanwezigheid van angineuze klachten - in negatieve betekenis- zwaarder te wegen bij de lage dan bij de hoge beroepen.

De opsplitsing van de groep in twee leeftijdsklassen geeft geen inzicht in het kontinue verloop van het percentage hervatters met de leeftijd. Bij een nadere analyse blijkt dit percentage vrijwel monotoon met de leeftijd te dalen bij de lage beroepen, terwijl dit verschijnsel bij de hoge beroepen eerst na de leeftijd van 54 jaar inzet. Men zou dit kunnen opvatten als een beschermende werking die een hoog beroep heeft op het negatieve effekt van leeftijd op de hervatting.

Tabel 4.6 geeft antwoord op de voor de hand 1iggende volgende vraag, namelijk of de drie faktoren eveneens van inkloed zijn op gehele of gedeeltelijke hervatting. In deze tabel onderkent men vrijwel dezelfde effekten van leeftijd en beroep als bij de vorige analyse. Angina pectoris blijkt evenwel meer differentiatie aan te brengen, met name ook weer bij de lage beroepen, dan voor hervatting op zich. 
Tabel 4.6: Mate van hervatting naar leeftijd, beroep en angina pectoris (CARGO-onderzoek)

\begin{tabular}{lccccc}
\hline & & \multicolumn{4}{c}{ hervatting $(8)$} \\
\cline { 3 - 6 } & Aeeftijd & $\begin{array}{c}\text { 'hoge } \\
\text { geheel }\end{array}$ & $\begin{array}{c}\text { beroepen } \\
\text { gedeelt. }\end{array}$ & $\begin{array}{c}\text { 'lage' } \\
\text { geheel }\end{array}$ & $\begin{array}{c}\text { beroepen } \\
\text { gedeelt. }\end{array}$ \\
\hline AP- & $<55$ & 67 & 30 & 57 & 29 \\
AP+ & $<55$ & 45 & 36 & 21 & 33 \\
AP- & $>55$ & 52 & 24 & 36 & 24 \\
AP+ & $>55$ & 31 & 35 & 9 & 24 \\
\hline
\end{tabular}

Het is inmiddels niet verwonderlijk zich af te vragen of de drie hier behandelde faktoren mede van invloed zijn op de snelheid waarmee hervat wordt. On deze vraag te kunnen beantwoorden zal per kombinatie worden nagegaan welk percentage binnen zes maanden na infarct het werk hervat heeft (tabel 4.7).

Tabel 4.7: Hervatting binnen zes maanden na infarct naar leeftijd, beroep en angina pectoris (CARGo-onderzoek)

\begin{tabular}{lccccc}
\hline & & \multicolumn{5}{c}{ hervatting } \\
\cline { 3 - 6 } AP & leeftijd & $\begin{array}{c}\text { 'hoge } \\
8\end{array}$ & $\begin{array}{c}\text { beroepen } \\
(\mathrm{n})\end{array}$ & $\begin{array}{c}\text { 'Tage' } \\
6\end{array}$ & $\begin{array}{c}\text { beroepen } \\
(\mathrm{n})\end{array}$ \\
\hline $\mathrm{AP}-$ & $<55$ & 72 & $(88)$ & 69 & $(146)$ \\
$\mathrm{AP}+$ & $<55$ & 71 & $(31)$ & 33 & $(117)$ \\
$\mathrm{AP}-$ & $>55$ & 64 & $(55)$ & 49 & $(82)$ \\
AP+ & $>55$ & 48 & $(29)$ & 22 & $(110)$ \\
\hline
\end{tabular}

Globaal gesproken zien we dezelfde effekten van bercep, leeftijd en angina pectoris zoals die naar voren kwamen bij de analyse naar hervatting op zich en de mate van hervatting. 
Ex is echter nauwelijks een verschil tussen hoge en lage beroepen voor de kombinatie AP-, <55 jaar. Het extra negatieve effekt van AP+ voor de lage beroepen is daarentegen wederom duidelijk aanwezig.

Tenslotte blijkt beroepsniveau nog van invloed te zijn op de terugkeer in eigen dan wel ander werk: patiënten met hoge beroepen keren in grotere getale terug naar hun eigen werk, dan patiënten met lage beroepen ( 80 versus 60\%), daarentegen krijgen de lage beroepen meer te maken met aangepast werk dan de hoge beroepen ( 30 versus $12 \%$ ). Voor belde beroepsniveaus geldt dat circa $10 \%$ ander werk vindt.

over het geheel genomen blijken de faktoren leeftijd, beroep en angina pectoris een vrij konsistente invloed uit te oefenen op respektievelijk hervatting op zichzelf, de mate van hervatting en in mindere mate op de snelheid waarmee wordt hervat. Hiermee is overigens niet gezegd dat de drie hier behandelde faktoren de enige zijn die een rol spe1en. Bij de introduktie van andere relevant geachte faktoren zal moeten blijken of deze eveneens een rol spelen en in hoeverre de effekten van leeftijd, beroep en angina pectoris blijven bestaan.

Het feit dat de kans op hervatting relatief klein is wanneer er sprake is van een laag beroepsniveau, wordt vaak teruggevoerd op de relatief hoge energetische belasting die gekoppeld is aan de werkzaamheden van personen met zo'n beroep. Om hier enig inzicht in te krijgen is de bedrijfsartsen gevraagd de zwaarte van het werk, zoals dat verricht werd voor het infarct, te schatten op drie aspekten: de energetische, de perceptief-mentale (informatieve) en de psycho-sociale belasting. Deze schattingen blijken naar verwachting samen te hangen met het beroepsniveau: hoe lager het beroep, des te zwaarder de energetische en hoe hoger het beroep, des te zwaarder de perceptief-mentale en de psycho-sociale belasting wordt geschat.

om het effekt van de geschatte energetische belasting op de hervatting te kunnen analyseren, is een opsplitsing van tabel. 4.5 naar deze faktoren noodzakelijk. Nu blijkt een dexgelijke opsplitsing voor de hoge beroepen niet veel zin te hebben, omdat deze overwegend (namelijk voor 85\%) als energetisch licht worden beschouwd. Voor de lage beroepen is deze analyse wel mogelijk (Tabel 4.8). 
Tabel 4.8: Percentage hervatters bij 'lage' beroepen naar leeftijd, angina pectoris en geschatte energetische belasting (CARGO-onderzoek)

\section{hervatting (8)}

geschatte energetische belasting:

licht
zwadel

zwar

\begin{tabular}{lcccc}
\hline AP- & $<55$ & 87 & 84 & 86 \\
& & $(\mathrm{n}=68)$ & $(\mathrm{n}=57)$ & $(\mathrm{n}=21)$ \\
$\mathrm{AP}+$ & $<55$ & 56 & 48 & 65 \\
& & $(\mathrm{n}=52)$ & $(\mathrm{n}=48)$ & $(\mathrm{n}=17)$ \\
$\mathrm{AP}-\quad>55$ & 62 & 69 & 20 \\
& & $(\mathrm{n}=37)$ & $(\mathrm{n}=35)$ & $(\mathrm{n}=10)$ \\
$\mathrm{AP}+\quad$ & 30 & 38 & 24 \\
& & $(\mathrm{n}=46)$ & $(\mathrm{n}=45)$ & $(\mathrm{n}=17)$ \\
\hline
\end{tabular}

Opvallend is dat beneden de leeftijd van 55 jaar zware energetische belasting in het geheel geen negatief effekt heeft op het percentage hervatters, terwijl juist wel van een negatief effekt sprake is boven die leeftijdsgrens. Wanneer voor de leeftijd van 55 jaar en ouder het percentage hervatters bij de als zwaar beoordeelde lage beroepen $\left(=22{ }^{2}\right)$ getoetst wordt tegen dat van de lichter geschütte $(=488)$, blijkt sprake te zijn van een signifikant verschil $\left(X_{I_{j}}=6.10\right.$, $\mathrm{df}=1, \mathrm{p}<.05$ ).

Wanneer ook de perceptief-mentale en psycho-soclale belasting in de beschouwing wordt betrokken, blijkt dat de percentages hervatters bij de hoge beroepen vrijwel steeds hoger liggen dan bij de lage beroepen, terwijl de geschatte zwaarte in de categorie hoog weinig differentiatie teweeg brengt in het percentage hervatters. voor lage beroepen in de kategorie AP- $>55$ blijkt een zwaarder geschatte niet-energetische belasting positief samen te hangen met hervatting. Dit effekt treedt vooral op ten aanzien van de psycho-sociale belasting, zodat verondersteld wordt, dat het hier gaat om met een zekere verantwoordelijkheld omgeven funkties. De konklusie is dus dat de hoge beroepen over het geheel ge- 
nomen een hoger percentage hervatters te zien geven dan de lage, dat zware energetische belasting een negatieve invloed heeft op de hervatting voor lage beroepen van 55 jaar en ouder en dat voor de categorie laag, AP- $<55$ een zwaarder geschatte niet-energetische belasting een positief verband heeft met het percentage hervatters. Als laatste aspekt van de ernst willen we hier de cardiale komplikaties en het recidief infarct behandelen. In de groep patienten met cardiale komplikaties ligt het hervattingspercentage op 48 , tegen 74 in de groep zonder. voor de groep patiënten met een recidief infarct is de kans op hervatting kleiner dan wanneer sprake is van een eerste infarct; de hervattingspercentages in de respektieve groepen zijn 53 en 69. Beide verschillen zijn signifikant (voor komplikaties $\mathrm{p}<.001$; voor recidief infarct $p<.05$ met $\chi_{L}^{2}$-toets)

Revalidatie: beschrijving

Revalidatie is een van de belangrijkere onafhankelijke variabelen in de analyse. In dit onderzoek is een onderscheid gemaakt tussen fysieke revalidatie en fysieke revalidatie plus matschappelijke begeleiding. Onder fysieke revalidatie wordt verstaan: geprogrameerde (bijvoorbeeld volgens WHO), fysieke rekonditionering na ontslag uit het ziekenhuis, al of niet onder direkte leiding. Maatschappelijke begeleiding wordt hier gedefinieerd als de professionele maatschappelijke casu quo psychologische begeleiding door de revaliderende instantie.

Van de 658 daarvoor in principe in aanmerking komende patienten werden ex uiteindelijk 197 (30\%) op een of andere manier gerevalideerd. Van deze groep werd slechts $22 \%$, dat wil zeggen 43 patiënten, bovendien nog maatschappelijk begeleid. Dit betekent dat niet meer dan $6.5 \%$ van de totale groep de volledige variant van revalidatie heeft genoten. In dit onderzoek kan de revalidatie worden beschreven aan de hand van vijf aspekten:

de plaats waar gerevalideerd wordt (in een centrum of revalidatie-afdeling van een ziekenhuis enerzijds of bij de behandelende specialist en/of fysioterapeut), de aanwezigheid van direkte leiding, aanvang en duur van de revalidatie en de aan- of afwezigheid van matschappelijke bege- 
leiding.

Gezien de beschikbare aantallen is het echter niet mogelijk al deze aspekten tegelijk in de analyse te betrekken.

vermeld is reeds dat de revalidatie in 78 van de gevallen beperkt blijft tot fysieke revalidatie, zodat om die reden gewenst is de analyse in hoofdzaak hierop te richten. Voorts lijken twee aspekten van bijzonder belang, te weten de aanvang van de revalidatie, omdat in het algemeen wordt aangenomen, dat een vroege revalidatie betere resultaten zal opleveren dan een late, en om beleidsmatige redenen lijkt de plaats van de revalidatie relevant. Daar de fysieke revalidatie in 94 a van de gevallen onder direkte leiding geschiedt zal de aan- of afwezigheid van direkte leiding hier verder buiten beschouwing blijven.

Het totale beeld van de revalidatie geeft een nogal verwarrende indruk. De revalidatie kan beginnen onmiddelijjk volgend op de ziekenhuisopname tot driekwart jaar na het infarct en kan éen week tot één jaar duren. Bovendien kan de revalidatie plaatsvinden in een centrum (in $41^{\circ}$ van de gevalien) of bij de behandelend specialist (voor 59\%). *) Er blijken dertig patiënten te zijn, die slechts gedurende Één tot drie weken gerevalideerd worden en die om een aantal redenen een kennelijk specifieke selektie vormen: ze komen voor ruim $40 \%$ uit én revalidatiecentrum, zijn gemiddeld 56 jaar en hebben overwegend een laag beroep. On deze redenen zal deze groep apart in de beschouwingen worden opgenomen.

De gemiddelde revalidatieduur van de resterende 167 patiënten bedroeg rond de twintig weken. Wat betreft de aanvang van de revalidatie blijkt dat de centra signifikant later revalideren dan de specialisten: $18 \%$ van de in de centra gerevalideerden begint binmen twee maanden na infarct aan het programma, terwijl dit percentage voor de specialist $60 \%$ bedraagt. Dit verschijnsel is te verklaren door o.a. het wachttijdenfenomeen, maar ook door het specifieke aanbod van de centra.

De vraag die naar voren komt is, welke patiënten nu de onderscheiden revalidatievormen ondergaan. Een revalidatie die binnen twee maanden na infarct begint is als 'vroeg'

*) Onder revalidatie in een centrum wordt verstaan klinische of poliklinische revalidatie met een bekend revalidatieprogramma. Ten tijde van het onderzoek betrof dit 14 centra. 
geklassiflceerd, de overige met uitzondering van de korte, als 'laat'. In tabel 4.9 is een aantal kenmerken van patienten opgenomen die enig licht op de zaak kunnen werpen. Uit deze tabel blijkt eens te meer hoe afwijkend de groep korte revalidatie is: bijna ultsluitend lage beroepen en een relatief hoog percentage angina pectoris.

Tabel 4.9: Kenmerken van patiënten naar type (fysieke) revalidatie (CARGo-onderzoek)*)

\begin{tabular}{|c|c|c|c|c|c|}
\hline revalidatie & $\begin{array}{c}\text { gemiddelde } \\
\text { leeftijd }\end{array}$ & $\begin{array}{c}\text { "Iage" } \\
\text { beroepen }\end{array}$ & $\begin{array}{c}\text { angina } \\
\text { pectoris }\end{array}$ & $\begin{array}{l}\text { recidief } \\
\text { infaret }\end{array}$ & $\begin{array}{l}\text { cardiale } \\
\text { kompli- } \\
\text { katies }\end{array}$ \\
\hline & jar & 然 & 8 & 政 & 傿 \\
\hline
\end{tabular}

korte revalidatie

$(n=30)$

56

93

57

3

13

vroeg in centrum

$(n=11)$

51.5

69

44

3

14

lat in centrum

$(n=50)$

51

81

47

11

31

vroeg bij specialist

$(n=64)$

52

71

48

9

20

laat bij specialist

$(n=42)$

52.5

63

46

11

20

fysieke revalidatie

met matsch. begeleiding

$(\mathrm{n}=43)$ $-\underline{51} \cdot \underline{5}$ $-81$ 44 $-23$

geen revalidatie

$(n=461)$

52.5

67

42

10

16

*) Vroege revalidatie start binnen twee maanden na infarct. Late revalidatie start later dan twee maanden na infarct.

Vooxal degenen die laat bij een centrum terecht komen springe eruit als een relatief slechte groep gezien het feit dat voor bijna eenderde ervan sprake is van komplikaties. In het geval van de late revalidatie, zowel in een centrum als bij de specialist, werkt drie maanden na het infarct, in tegenstelling tot de andere kategorieën, nog niemand, zodat 
mag worden aangenomen dat het nog niet hervat hebben van het werk mede een indikatie voor de revalidatie zal zijn geweest. De in de vragenlijst opgenomen vraag naar de indikatile blijkt ons hier nauwelijks behulpzaam te zijn doordat in bijna de helft van de gevalien die indikatie onbekend is.

Omdat in de analyse naar de relatie tussen revalidatie en hervatting nog verdere opsplitsingen te verwachten zijn, is hjer gekozen voor een voortzetting van de beschouwingen met de aanvang van de revaljatie als belangrijkste kenmerk.

Revalidatie en hervatting

Wij naderen de kernvraag van het onderzoek, namelijk of revalidatie van invloed is op werkhervatting. Wij hebben in hoofdstuk 4 al gezien dat het revalidatiegebeuren in Nederland een nogal verwarrend beeld tee zien geeft, zodanig dat de analyse niet naar alle aspekten kan worden ondernomen. Met behoud van de ons inziens belangrijkste aspekten kan het hoofdresultaat ten aanzien van de relatie revalidatie - hervatting worden weergegeven in tabel 4.10 .

Tabe1 4.10: Hervattingspercentage naar type (fysieke) revalidatie (CARGO-onderzoek)

Revalidatie

hervat ( $(8)$

\begin{tabular}{|c|c|c|c|}
\hline korte revalidatie & $(n=30)$ & & 43 \\
\hline vroeg in centrum & $(n=11)$ & 73 & 81 \\
\hline vroeg bij specialist & $(n=64)$ & $83^{\prime}$ & \\
\hline laat in centrum & $(n=50)$ & 62 & 63 \\
\hline lat bij specialist & $(n=42)$ & 64 & \\
\hline geen reval Latie & $(m=461)$ & & 68 \\
\hline $\begin{array}{l}\text { Eysieke revalidatie + } \\
\text { matsch. begeleiding }\end{array}$ & $(n=43)$ & & 72 \\
\hline
\end{tabular}

In het oog springend is het gunstige effekt van vroege revalidatie vergeleken met late en geen revalidatie. Daar de 
groep late revalidatie naar alle waarschijnlijkheid een negatieve selektie vormen dienen we in eerste instantie de vroege tegen geen revalidatie te toetsen. Het verschil in hervattingspercentage tussen beide kategorieen is signifikant $\left(X_{L}^{2}=6.14, d f=1, p<.05\right)$.

Het percentage hervatters bij de vroeg gerevalideerden ligt hoger dan in alle andere vormen van fysieke revalidatie: het verschil tussen vroeg en overig is eveneens signifikant $\left(X_{L}^{2}=8.08, d f=1, p<.01\right)$. Opmerkelijk is ook het relatief hoge hervattingspercentage bij de groep die naast fysleke ook matschappelijk begeleid wordt, ondanks het feit dat de groep $81 \%$ patienten met een laag bexoep bevat.

Om tot een juiste beoordeling van de resultaten betreffende de effekten van revalidatie te komen, is het nodig de faktoren leeftijd, beroep en angina pectoris in de beschouwing te betrekken. Deze faktoren oefenen immers een nogal grote invloed uit op het hervattingspercentage. Tabel 4.11 geeft de hervattingspercentages naar revalidatievorm en leeftijd, beroep en angina pectoris.

Tabel 4.11: Percentage hervatters naar fysieke revalidatie, leeftijd, beroep en angina pectoris (CARGO-onderzoek)

fysieke revalidatie

\begin{tabular}{llllllll} 
& & \multicolumn{2}{c}{ vroeg } & \multicolumn{2}{c}{ laat } & \multicolumn{2}{c}{ geen } \\
\hline \multirow{2}{*}{ Leeftijd } & $<55$ & 87 & $(47)$ & 74 & $(57)$ & 79 & $(267)$ \\
& $>55$ & 71 & $(28)$ & 46 & $(35)$ & 52 & $(194)$ \\
& & & & & & & \\
\hline beroep & laag & 77 & $(53)$ & 61 & $(67)$ & 59 & $(309)$ \\
& hoog & 91 & $(22)$ & 68 & $(25)$ & 86 & $(152)$ \\
& & & & & & & \\
\hline angina & AP- & 93 & $(41)$ & 72 & $(50)$ & 81 & $(269)$ \\
pectoris & APt & 68 & $(34)$ & 52 & $(42)$ & 49 & $(192)$
\end{tabular}


Globaal gezien zijn de effekten van revalidatie en de drie andere faktoren nog aanwezig. Er treedt echter slechts tweemaal een signifikant verschil op tussen het hervattingspercentage in vroege en geen revalidatie: bij lage beroepen ( 77 versus 59:, $x_{\mathrm{L}}^{2}=6.95$, df $\left.=1, \mathrm{p}<.001\right)$ en bij APt $(68$ versus $\left.49 \%, X_{L}^{2}=4.13, d f=1, p<.05\right)$. Het positieve effekt van vroege revalidatie op de hervatting is dus vooral gebaseerd op deze twee kategorieën.

De duur van de revalidatie blijkt geen eenduidige invloed op de hervatting te hebben; weliswaar hebben lange revalidatieduren $(>22$ weken) een 1 icht negatief effeikt op het hervattingspercentage, doch dit komt vooral doordat deze langere duren gerealiseerd worden in late revalidatie, dus wanneer naar alle waarschijnlijkheid al sprake is van hervattingsproblematiek. Voorts blijkt dat in $39 \%$ van de gevalien de revalidatie voortduurt tijdens de hervatting; het is inderdaad de gewoonte dat tijdens de revalidatie zo veel mogelijk geprobeerd wordt de patiënten gedeeltelijk het werk te laten hervatten. De revalidatie gaat op deze wijze vloeiend over in de hervatting. In het merendeel van de gevallen is echter sprake van een interval tussen einde revalidatie en hervatting, dat gemiddeld ongeveer anderhalf à twee maanden beslaat. Het effekt van revalidatie op volledige of gedeeltelijke hervatting is beschreven door vermeulen (1978): hij vond in een onderzoek, waarbij door random-toewljzing patiënten wel of niet gerevalideerd werden, een positief effekt. van revalidatie op de mate van hervatting. Wanneer voor dit onderzoek deze vergelijking wordt gemakt door de groep vroege revalidatie op dit punt te vergelijken met. de groep geen revalidatie wordt eenzelfde resultaat verkregen: in de groep vroege revalidatie hervat 698 geheel, tegen 55\%. in de groep die niet gerevalideerd werd (tabel. 4.12).

Het eerder vermelde onderzoek van vermeulen had onder meer ook als resultaat dat revalidatie het tijdstip van hervatting uitstelt, zoals men op plausibele gronden mag verwachten. 
Tabel 4.12: Fysieke revalidatie en mate van hervatting (CARGo-onderzoek)

\begin{tabular}{|c|c|c|}
\hline \multirow[b]{2}{*}{ hervateing } & \multicolumn{2}{|c|}{ revalidatie } \\
\hline & vroeg & geen \\
\hline gehee 1 & 69 & 55 \\
\hline \multirow[t]{2}{*}{ gedee 1 telijk } & 31 & 45 \\
\hline & $(61)$ & $(312)$ \\
\hline
\end{tabular}

In tabe 4.13 zijn de percentages aangegeven betreffende het aantal patiênten, die binnen een half jaar na infarct hervatten naar de verschillende vormen van revalidatie.

Tabel 4.13: Percentage hervat $\$ 6$ manden na MI naar type (fysieke) revalidatie (CARGO-onderzoek)

\begin{tabular}{lcc}
\hline & $\begin{array}{c}\text { hervat binnen half jaar } \\
\text { revalidatie }\end{array}$ & $\mathrm{n}$ \\
\hline korte revalidatie & 33 & $(30)$ \\
vroege revalidatie & 55 & $(75)$ \\
late revalidatie & 34 & $(92)$ \\
geen revalidatie & 54 & $(461)$ \\
maatschappelijk bege- & 67 & $(43)$ \\
Lejd &
\end{tabular}

Uit ait onderzoek komt naar voren dat een uitstel van de hervatting vooral voor rekening komt van de late revalidatie. Opmerkelijk is het hoge percentage dat binnen een half jaar heeft hervat in de groep die ook matschappe1.jk begeleid is, dit ondanks het feit dat in deze groep evenveel vroege als late revalidaties plaatsvinden. 
Samenvattende analyses

In de voorafgaande paragrafen is gebleken dat leeftija, beroep en angina pectoris effekt hebben op hervatting op zichzelf, de mate van hervatting en in mindere mate op het interval infarct - hervatting. Daarnaast werden negatieve effekten gevonden van cardiale komplikaties en recidief infarct op hervatting, terwijl beroep van invloed bleek te zijn op het al dan niet hervatten in het eigen werk. Tenslotte konden positieve effekten van vrcege fysieke revalidatie genoteerd worden op hervatting en mate van hervatting.

De samenvattende beschrijving heeft tot doel na te gaan of de gevonden effekten stand houden wanneex de faktoren tegelijk in de analyse worden betrokken. De analysetechniek die tot nu toe gebruikt is, namelijk analyse met behulp van kruistabellen, is dan niet meer brulkbaar. Hier is gekozen voor een multiple regressie-analyse, zodat ook nog andere relevant geachte faktoren kunnen worden ingevoerd. Deze techniek geeft bovendien inzicht in het relatieve gewicht van de onafhankelijken in de voorspeling van de afhankelijken in de vorm van de gestandaardiseerde partiele regressiekoëfficiënten ( $\beta$ ).

De valgende nieuwe onafhankelijke variabelen werden gebruikt: de opnameduur in het ziekenhuis, deze kan zowel gezien worden als een indikatie van de ernst (er is een signifikante, positieve samenhang tussen opnameduur en cardiale komplikaties), als van het type ziekenhuis waar de patiënt is opgenomen (Academische ziekenthizen hebben kortere gemiddelde opnameduren dan ziekenhuizen war geen cardiologen aanwezig zijn, Diedexiks, 1980); veranderingen in de arbeidstaak om gezondheidsredenen vór infarct als indikatie van pre-infaret problemen, die naar verwachting de hervatting zullen bemoeliljken;

de geschatte zwaarte in de arbeldstaak komt in de analyse voor als een gesommeerde index over de drie belastingsaspekten:

De analyse is achtereenvolgens uitgevoerd op hervatting op zichzelf, de mate van hervatting, hervatting in eigen of ander werk en het interval infarct-hervatting. De gevolgde procedure houdt in dat eerst in een stapsgewijze analyse die variabelen worden opgespoord die signifikante regressiekoëfficiënten opleveren. Met die variabelen werd 
tenslotte een gewone regressie-analyse uitgevoerd. De resultaten zijn weergegeven in tabel 4.14 .

Tabel 4.14: Multiple regressie-analyse op vier hervattingsvariabelen (CARGO-onderzoek)

\begin{tabular}{|c|c|c|c|c|c|c|c|c|}
\hline \multirow[b]{2}{*}{ onathankelijken: } & \multicolumn{2}{|c|}{$\begin{array}{l}\text { niet hervat } \\
\text { hervat }\end{array}$} & \multicolumn{2}{|c|}{$\begin{array}{l}\text { gedeelt/ } \\
\text { geheel. }\end{array}$} & \multirow{2}{*}{\multicolumn{2}{|c|}{ 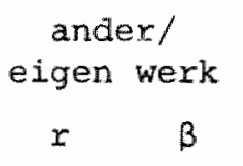 }} & \multicolumn{2}{|c|}{ interval } \\
\hline & $r$ & $\beta$ & $r$ & $B$ & & & $r$ & $\beta$ \\
\hline leeftijd & -.34 & -.30 & -.11 & -.12 & 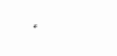 & & & \\
\hline angina pectoris & -.33 & -.24 & -.25 & -.24 & -.13 & -.10 & .11 & .10 \\
\hline beroepsnivean & .24 & .21 & .17 & .17 & .18 & .20 & & \\
\hline komplikatjes & -.11 & -.10 & & & -.15 & -.17 & .17 & .15 \\
\hline $\begin{array}{l}\text { fysieke reva- } \\
\text { Iidatie }\end{array}$ & .12 & .10 & .10 & .16 & & & & \\
\hline recidief infarct & $t-10$ & -.08 & & & & & & \\
\hline opnameduur & & & & & & & .15 & .13 \\
\hline $\begin{array}{l}\text { multiple korre- } \\
\text { latie }\end{array}$ & & $\begin{array}{l}.51 \\
01 \\
658)\end{array}$ & & $\begin{array}{l}=.34 \\
.01 \\
=444)\end{array}$ & & $\begin{array}{l}=.27 \\
<.01 \\
a=444)\end{array}$ & & $\begin{array}{l}.23 \\
.01 \\
=444)\end{array}$ \\
\hline
\end{tabular}

Weergegeven $z i j n$ de nulde-orde korrelatie, $r$, en de gestandaa diseerde regressiekoëficiënten, $\beta$. *)

Bij een eerste beschouwing vallen twee zaken op. Ten eerste 1 s een dominante 1 invloed van angina pectoris, beraep en cardiale komplikaties waarneembaar. Ten tweede is op te merken dat de hoeveelheid "verklaarde" variantie binnen de groep hervatters beduidend lager ligt dan in de totale groep (de 'verklaarde' variantie is het kwadraat van de multiple korrelatie). Dit laatste kan betekenen dat bij de analyse binnen de groep hervatters niet over voldoende relevante voorspellers kon worden beschikt.

* In bijlage 7 is de kodering van de variabelen gespecificeerd. Bovendien is daar de korrelatiematrix gegeven. 
Voor herwatting op zichzelf blijken de drie belangrijkste voorspellers de reeds uitvoerig behandelde variabelen leettijd, angina pectoris en beroepsniveau te zijn. Het effekt. van vroege fysieke revalidatie op hervatting blijft gehandhata bij konstant houden van de overige vaxiabelen. Voor gehele of gedeeltelijke hervatting zijn angina pectoris en beroepsniveau de belangrijkste voorspellers. Wanneer de overige variabelen konstant worden gehouden, blijkt fysieke revalidatie an invloed te winnen.

Voor de hervatting in eigen of ander werk is beroepsniveau de belangrijkste voorspeller, op de voet gevolgd door cardiale komplikaties.

Komplikaties, opnameduur en angina pectoris hebben een positief verband met het interval infarct - hervatting. De aanwezigheid van komplikaties, langere opnameduren en het hebben van angineuze klachten verlengen dus de ziekteduur. Wanneer per afhankelijke de invloedrijkste determinant wordt gekozen ontstaat het volgende beeld: of iemand na zijn hartinfarct het werk zal hervatten wordt vooral bepaald door zijn leeftijd, hoe ouder, hoe kleiner de kans op hervatting. Als er al sprake is van hervatting zal angina pectoris de kans op gehele hervatting verkleinen, terwijl een hoog beroep de kans dat hij in zijn eigen werk terugkeert vergroot. Tenslotte vergroten vooral cardiale komplikaties de kans dat het hervattingstijastip wordt uitgesteld.

\section{4 Sukses van hervatting}

Hoofalijnen

Het sukses van hervatting wordt hier benaderd in termen van ziekteverzuim, omat hler de objektieve benadering van het sukses wordt nagestreefd. In hoofdstuk 1 is al beschreven dat het aantonen van een 'akseptabel' ziekteverzuim bij hartinfarctpatienten al vroeg een oogmexk is geweest van de onderzoekers op dit gebied.

Het ziekteverzuim in de zes maanden na de hervatting heeft betrekking op 153 mannen, dat wi]. zeggen 34.58 van de hervatters heeft $z i c h$ in die periode én of meerdere keren afgemeld wegens ziekte. Tabel 4.15 laat zien hoe het ziekteverzuim eruit ziet naar frekwentie en duur. 
Tabel 4.15: Ziekteverzuim in de eerste zes maanden na de hervatting

\begin{tabular}{|c|c|c|c|c|}
\hline \multirow[b]{2}{*}{ verzuimauur } & \multicolumn{4}{|c|}{ Erekwentie } \\
\hline & $1 x$ & $2 x$ & $3-4 x$ & totaal \\
\hline kort: $<14$ dagen & $54 \%$ & $25 \%$ & $22 \%$ & (69) \\
\hline lang: $>14$ dagen & $\begin{array}{r}46 \% \\
(107)\end{array}$ & $\begin{array}{l}758 \\
(28)\end{array}$ & $\begin{array}{r}788 \\
(18)\end{array}$ & $\begin{array}{r}(84) \\
(153)\end{array}$ \\
\hline $\begin{array}{l}\text { gemiddeld aantal } \\
\text { verzuimdagen } \\
\text { mediaan }\end{array}$ & $\begin{array}{l}25 \\
14\end{array}$ & $\begin{array}{l}39 \\
28\end{array}$ & $\begin{array}{l}31 \\
31\end{array}$ & $\begin{array}{l}38 \\
34\end{array}$ \\
\hline $\begin{array}{l}\text { gemiddeld aantal } \\
\text { dagen per verzuim }\end{array}$ & 25 & 19 & 9 & n.v.t. \\
\hline
\end{tabular}

Het merendeel van het vexzuim komt voor rekening van degenen die zich énnaal hebben ziekgemeld. In deze groep komen zowel korte als lange verzuimduren voor. Degenen die zich meerdere keren hebben ziekgemeld, hebben een langere totale verzuimduur.

De verzuimdiagnose wordt in hoofdzaak bepaald door vier diagnosegroepen: circulatie, psychische aandoeningen (men mag aannemen dat deze in verband staan met het doorgemaakte infarct) en infekties plus ademhaling.

Naarmate meerdere malen wordt verzuimd, wordt het aandeel van circulatie plus psychische aandoeningen relatief groter (tabel 4,16 ).

Tabel 4.16: Verzuimdiagnose naar verzuimfrekwentie

\begin{tabular}{lccc}
\hline & $\begin{array}{c}\text { 1x verzuima } \\
1 \text { e verzuim }\end{array}$ & \multicolumn{2}{c}{2 le verzuim } \\
& $17 \%$ & $22 \%$ & $26 \%$ \\
circulatie & $12 \%$ & $17 \%$ & $22 \%$ \\
psychische aandoeningen & $42 \%$ & $46 \%$ & 418 \\
infekties en ademhaling & $21 \%$ & $15 \%$ & $11 \%$ \\
overige & $8 \%$ & - & - \\
onbekend & $(107)$ & $(46)$ & $(46)$ \\
\hline
\end{tabular}


Wanneer een vergelijking wordt gemaakt met landelijke verzuimcijfers moet een aantal zaken in het oog worden gehouden:

1. De hervatters vormen een selektie uit de infarctpatienten naar jongere leeftijden, hogere beroepen en een geringere ernst van het infarct. Het effekt van de selektie naar jongere leeftijden wordt echter meex dan tenietgedaan door het feit dat de infarctgroep als geheel gemiadeld ouder is dan de mannen uit de landelijke verzuimstatistiek. Naar verwachting zullen in vergelijking met deze laatstgenoemde groep bij de hervatters relatief meer hogere beroepen voorkomen.

In vergelijking met landelijke cijfers moet kortom rekening worden gehouden met het feit dat de hervatters een gemiddeld oudere groep vormen met een relatieve oververtegenwoordiging van hoge beroepen.

2. De hervatters zullen, zeker daar het de eerste zes manden na hervatting betreft, nauwelijks in die periode bekende arbeidsongeschiktheidsgevallen bevatten. Bovendien is het netto aantal hervatters reeds gekorrigeerd voor acht definitieve uitvallers.

In tabel 4.17 is een vergelijking gemaakt tussen de verzuimcijfexs uit het CARGO-onderzoek en landelijke cijfers voor de leeftijdsgroepen onder de 55 en 55 jaar en ouder.

Tabel 4.17: Kerngetallen van het ziekteverzuim bij de hervatters uit het CARGO-onderzoek vergeleken met landelijke cijfers*)

\begin{tabular}{lcccc}
\hline & \multicolumn{2}{c}{$\begin{array}{c}\text { CARGO-onderzoek**) } \\
\text { leeftijd }\end{array}$} & \multicolumn{2}{c}{ Landelijk onderzoek } \\
verzuimmaten & $<55$ & $>55$ & $<55$ & leeftijd \\
\hline verzuimfrekwentie & 1.15 & 0.72 & 1.52 & 1.17 \\
verzuimpercentage & 6.0 & 4.0 & 7.6 & 11.4 \\
verzuimduur & 19.1 & 20.6 & 18.6 & 35.8 \\
\hline
\end{tabular}

*) De landelijke cijfers zijn afkomstig uit soeters, 1980. Het betreft gewogen gemiddelden over 1976 en 1977.

**) De registratieperiode betrof een half jaar. De verzuimcijfers zijn omgerekend naax een kalenderjaar. 
De hervatters jonger dan 55 jaar verzuimen minder vaak, zij het dat de geniddelde verzuimduur vergelijkbaar is met het landelijke cijfer. Wellicht is de lagere verzuimfrekwentie toe te schxijven aan de relatieve oververtegenwoordiging van de hogere beroepen bij de hervatters. De verschillen tussen de verzuimcijfers van de hervatters van 55 en oudex met de landelijke cijfers zijn aanzienlijk. Deze verschillen zijn waarschijnlijk te verklaren door een uitzuivering van wAO-effekten in deze groep. Voor deze groep geldt zeker ook dat de registratieperiode van een half jaar een onderschatting van langere ziekteduren waarschijnlijk maakt. Uit de gepresenteerde cijfers valt echter niet te konkluderen dat hartinfarctpatiënten die het werk hebben hervat, wat. het ziekteverzuim betreft op ongunstige wijze zouden verschililen van de landelijke cijfers.

\subsection{Faktoren die samenhangen met sukses van hervatting}

Leeftijd, beroep, angina pectoris

Naast het ziekteverzuim als maat voor het sukses van de hervatting, zijn ook de oordelen van de bedrijfsarts en de patient omtrent het welslagen van de hervatting gehanteerd. Daar in dit hoofdstuk objektief herstel aan de orde is, zal hier worden gewerkt met het oordeel van de bedrijfsarts in kombinatie met het ziekteverzuim (tabel 4.18 ).

Tabel 4.18: Ziekteverzuim en oordeel bedrijfsarts over sukses van hervatting (abs.getallen) (CARGO-onderzoek)

cordeel bedrijfsarts

$$
\begin{gathered}
\text { redelijk goed } \\
\text { geslaagd }
\end{gathered}
$$

verzuim matig

geslaagd
Totaal

\begin{tabular}{lccc}
\hline geen verzuim & 36 & 250 & 286 \\
$\begin{array}{l}\text { 1x kort verzuim } \\
\text { meer en/of langer }\end{array}$ & 11 & 47 & 58 \\
veruim & 33 & 57 & 90 \\
\hdashline totaal & 80 & 354 & 434 \\
\hline
\end{tabular}


In de kategorie matig sukses komen zowel nul-verzuimers als diegenen, die meerdere keren, dan wel langer verzulnd hebben in behoorlijke aantallen voor. Als geslaagde hervatters worden nu die nul-verzuimers beschouwd, die bovendien naar het oordeel ran de bedrijfsarts op een suksesvolle hervatting kunnen bogen. De op deze wijze gedefiniëerde geslaagde hervatters vormen een kleine meerderheid van de totale groep hervatters (56:).

Wanneer het sukses van hervatting geanalyseerd worat naar leeftija, angina pectoris en beroep (tabel 4.19 ), blijkt vooral angina pectoris een negatieve invloed te hebben. De percentages geslaagde hervatters liggen voor de hoge beroepen in het algemeen hoger dan bij lage beroepen, zij het in mindere mate boven de leeftijd van 55 . Als ex al sprake is van een leeftijaseffekt, dan is dit in dit geval positief: er zijn relatief meer oudere geslaagde hervatters, vooral bij de lage beroepen met angina pectoris.

Tabe1 4.19: Geslaagde hervatting naar leeftijd, beroep en angina pectoris (CARGO-onderzoek)

\begin{tabular}{|c|c|c|c|c|c|}
\hline \multirow[b]{2}{*}{$\begin{array}{l}\text { angina } \\
\text { pectoris }\end{array}$} & \multirow[b]{2}{*}{ leeftijd } & \multicolumn{4}{|c|}{ geslaagde hervatting } \\
\hline & & hoge & $\begin{array}{c}\text { beroepen } \\
(\mathrm{n})\end{array}$ & lage & $\begin{array}{c}\text { beroepen } \\
(\mathrm{n})\end{array}$ \\
\hline $\mathrm{AP}-$ & $<55$ & 63 & $(84)$ & 55 & $(126)$ \\
\hline$A P+$ & $<55$ & 56 & $(25)$ & 40 & $(63)$ \\
\hline $\mathrm{AP}-$ & 55 & 67 & $(42)$ & 61 & (49) \\
\hline$A P+$ & $>055$ & 58 & $(29)$ & 53 & $(36)$ \\
\hline
\end{tabular}

Aangezien de groep suksesvolle hervatters uitsluitend uit nul-verzuimers bestaat, is het duidelijk dat faktoren waarvan bekend is dat ze het ziekteverzuim beinvioeden een rol. zullen spelen.

Zo verzuimen hoge beroepen minder dan lage en zal de aanwezigheid van angina pectoris verzuimverhogend werken. Opvallend blijft dan wel dat de leeftijd hier geen rol blijkt te spelen. Dit heeft wellicht mede te maken met het eerder genoemde selektie-effekt naar de jongere leeftijden; de hervat- 
ters zijn voor tweederde jonger dan 55 jaar. Niettemin blijft staan dat de analyse van het sukses van hervatting in termen van ziekteverzuim, neerkomt op een ziekteverzuimanaiyse bij hervattende infarctpatiënten. Aangezien ziekteverzuim met name ook beinvloed wordt door bedrijfsgebonden faktoren, zullen de ons beschikbare gegevens slechts zeer ten dele licht kunnen werpen op een verklaring van verschillen in het verzuim en dus van verschillen in sukses.

\section{Revalidatie}

Wij hebben reeds gezien dat fysieke revalidatie een positieve rol speelt bij de werkhervatting; een vroege revalidatie beinvloedt het percentage hervatters in gunstige zin. Het was weliswaar geen indrukwekkend bewijs wat hiervoor geleverd kon worden, maar in de regressie-analyse bleek de faktor revalidatie toch nog een bescheiden rol te kunnen spelen naast zulke dominerende faktoren als leeftijd, beroep en angina pectoris.

Blijft de vraag of vroege fysieke revalidatie ook een rol speelt bij het sukses van de hervatting. Verondersteld kan bij voorbeeld worden dat vooral de vroeg gerevalideerdan beter zijn voorbereid op een aantal eisen die werkhervatting stelt, zoals een adekwate lichamelijke konditie, zelfvertrouwen, besef van de eigen mogelijkheden, e.d.

Wanneer allereerst de relatie bezien wordt tussen een drietal verzuimmaten en fysieke revalidatie (tabel 4.20 ) valt op dat de cijfers voor vroege en geen revalidatie zich weinig van elkaar onderscheiden. De groep laat gerevalideerden vertoont de ongunstigste cijfers, hetgeen nadere steun verleent aan de veronderstelling, dat het hier een bepalde, ongunstige, selektie betreft.

Tabel 4.20: Fysieke revalidatie en ziekteverzuim

verzuim- verzuim- gemiddelde fysieke revalidatie frekwentie percentage verzuimduur (dagen)

\begin{tabular}{llll}
\hline vroeg: $<2$ mnd.na infarct & 0.90 & 4.3 & 17.2 \\
laat $:>2$ mnd. na infarct & 0.91 & 6.5 & 26.0 \\
geen & 1.07 & 5.1 & 17.4
\end{tabular}


Gezien de bovenstaande resultaten is het te verwachten dat ook ten aanzien van de geslaagde versus de minder geslaagde hervatters geen relatie met revalidatie is aan te tonen. Het beeld in tabel. 4.21 komt dan ook overeen met het beeld van de relatie revalidatie en ziekteverzuim: weinig verschil tussen vroege en geen revalidatie en de late revalidatie als het relatief ongunstigst.

Tabel 4.21: Fysieke revalidatie en sukses van werkhervatting

fysieke revalidatie

vroeg: $\leqslant 2$ mnd. na infarct

laat $:>2$ mnd. na infarct

geen geslaagde hervatters

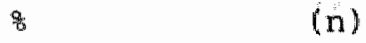

60

52

55

Samenvattende analyse

op dezelfde wijze als beschreven voor de groepen hervatters. niet-hervatters is een regressie-analyse gedaan op de afhankelijke variabele geslaagde hervatting. Tot de geslaagde hervatters werden de nul-verzuimers gerekend die bovendien naar het oordeel van de bedrijfsarts op een suksesvolle hervatting kunnen bogen.

Aan de lijst van onafhankelijken is gehele of gedeeltelijke hervatting toegevoegd. Het resultat van de regressie-analyse vindt men in tabel 4.22 .

Tabe1 4.22: Multiple regressie-analyse op geslaagde hervatting

onafhankelijke

hervatting niet/wel geslaagd

Ona fhankelijke

gedeeltelijk/geheel hervat

$r$ B

beroep .26 .23

belasting in axbeid vór infarct

komplikaties

$$
\begin{array}{r}
.13 \\
-.09
\end{array}
$$$$
.15
$$$$
-.14
$$

multiple korrelatie $= \pm 13$ $- \pm 13$ 
Het gekozen kriterium van geslaagde hervatting blijkt vooral samen te hangen met de mate van hervatting: bij gehele hervatting komt relatief meer geslaagde hervatting voor. Hoge bexoepen maken een grotere kans op een geslaagde hervatting, terwijl zwaar werk (gesommeerde index) en cardiale komplikaties de kans op sukses verkleinen. Opvallend is dat de negatieve nulde-orde korxelatie tussen angina pectoris en het sukses van de hervatting, geen stand houdt in de regressie-analyse. Daar angina pectoris negatief korreleert met gehele hervatting, kan worden verondersteld dat angina pectoris niet rechtstreeks, doch via de mate van hervatting van invloed is op het hervattingssukses.

\subsection{Samenvatting en diskussie}

In dit hoofdstuk is werkhervatting benaderd als objektief herstel. De deelvraagstellingen van het CARGo-onderzoek, namelijk betreffende de mate, wijze en sukses van werkhervatting en de daarmee samenhangende faktoren, zijn hierin goeddeels behandeld. Werkhervatting als subjektief herstel zal in het volgende hoofdstuk worden behandeld, daar zal men ook een algemene beschouwing over het CARGo-onderzoek vinden.

De resultaten van dit hoofdstuk zullen per deelvraagstelling worden samengevat en van kommentaar worden voorzien.

De mate van hervatting is in dit onderzoek zowel opgevat als het percentage van de overlevenden dat het werk horvat, als de verdeling van dit percentage over gedeeltelijke en gehele hervatting. Het 'overall' percentage hervatters bleek 65 te bedragen. Ruim de helft van de hervatters keerde terug naar een volledige baan. Het is wellicht illustratief na te gaan welk deel van de totale onderzoeksgroep terugkeert naar een volledige baan. Van het totaal aantal mannen dat door een hartinfarct werd getroffen keerde uiteindelijk $28 \%$ weer geheel en $22 \%$ gedeeltelijk terug in het werk. Al met al betekent dit dat de helft van de onderzoeksgroep het werk hervatte, een deel overleden is (23\%), een deel het werk niet hervatte (24\%) en dat voor een klein deel (3\%) het infarct aanleiding was tot vervroegde pensionering. 
Bij de wijze van hervatting gat het om de vraag hoevee 1 tija verloopt tussen infarct en hervatting en om de vraag in hoeverre het werk meteen of eerst gedeeltelijk en vervolgens geheel wordt hervat. De kans op herintreding bleek het grootst te zijn in het eerste halfjaar na infarct: $50 \%$ van de overlevenden hervat in die periode, dit is drievierde var de groep die uiteindelijk hervatte. De kans op hervatting is in het tweede halfjaar aanzienlijk kleiner, max beslist niet te verwariozen, een kleine 20 gervatte nog in die periode. Slechts een klein deel van de hervatters (78) hervat meteen geheel het werk. Voor het overgrote deel geldt dat de gehele hervatting verliep via gedeeltelijke hervatting. van de hervatters keert circa tweederde terug naar eigen werk, een kwart naar eigen, aangepast werk, terwijl circa $10 \%$ ander werk vond.

Wat betreft faktoren die met hervatting samenhangen is in de 1 iteratuur redelijke overeenstemming over de invloed van leeftijd, beroep en ernst van het infarct. De ernst is hier benaderd door de infarcten te klassificeren met behulp van de aan- of afwezigheid van komplikaties en angina pectoris, en het gegeven of het al dan niet een recidief infarct betrof.

Wij zijn er ons van bewust dat het hier slechts globale benaderingen van het koncept 'ernst' betreft. Meer precieze maten zoals de grootte van het infarct hadden we echter niet tot onze beschikking. De bevindingen van dit onderzoek bevestigen nog eens dat oudere infarctpatiënten, patienten met een laag bexoepsniveau en patiênten met ean ernstig infarct minder kans op hervatting hebben. De veronderstelling dat wooral de hogere energetische belasting van lage beroepen een negatieve rol speelt bij de hervatting, blijkt in dit onderzoek slechts op te gaan voor patienten met lage beroepen ouder dan 55 jaar, althans op basis van de door de bedrijfsarts geschatte energetische belasting van de werkzaamheden van vór het infarct. Elders is al beschreven welke problemen verbonden zijn met deze schatting (Diederiks, 1980), zodat dit resultat als voorlopig moet worden gekenmerkt.

In dit onderzoek is onderscheld gemaakt tussen fysieke revalidatie en fysieke revalidatie plus matschappelijke 
begeleiding. In totaal bleek $30 \%$ van de patiënten op een of andere manier gerevalideerd te zijn. Niet meer dan 6.5\% genoot de volledige variant van revalidatie, dat wil zeggen fysieke revalidatie plus matschappelijke begeleiding. Het totale beela van de revalidatie is nogal verwarrend. De revalidatie kan beglnnen onmiddeliljk volgend op de ziekenhuisopname tot driekwart jaar na het infarct en kan én week tot én jaar duren. Bovendien kan de revalidatie plaats vinden in een centrum of bij de behandelend specialist. over het geheel genomen is revalidatie niet van invloed op werkhervatting. Wel blijkt dat wroege fysieke revalidatie, dat wil zeggen beginnend binnen twee maanden na infarct, een positieve invloed heeft op zowel het percentage werkhervatters als op het percentage patienten dat het werk geheel hervat. De positieve invloed van fysieke revalidatie op gehele hervatting is in overeenstemming met de bevinding van vermeulen et al. (1978). Het uitsteleffekt van revalidatie op het tijdstip van hervatting, wat over het geheel genomen duidelijk waarneembaar is, moet worden toegeschreven aan late revalidatie. Dit is niet in overeenstemming met het onderzoek van Vermeulen, waar ook voor een programma met een betrekkelijk vroege start een uitsteleffekt werd gevonden.

Door de toepassing van een multiple regressie-analyse op de afhankelijke hervatting is gepoogd de determinanten ervan in hun onderlinge samenhang en naar hun relatieve gewicht te beschrijven. In volgorde van gewicht zijn de best voorspellende variabelen: leeftijd (-), angina pectoris (-), beroep ( + , komplikaties $(-)$, vroege fysieke revalidatie $(+)$ en recidief infarct $(-)$. Gehele hervatting blijkt, op analoge wijze geanalysecrd, voorspeld te worden door: angina pectoris (-), beroep $(+)$, vroege fysieke revalidatie (t) en leeftijd (-). Hervatting in eigen werk wordt voorspeld door: beroep $(+)$, komplikaties $(-)$, en angina pectoris (-). Het interval infarct - hervatting wordt verlengd door komplikaties, angina pectoris en door de opnameduur. Hervatting op zichzelf blijkt het best voorspeld te kunmen worden: de hoeveelheid verklaarde variantie is $26 \%$. Binnen de groep hervatters, dus bij de analyse naar gehele hervatting, hervatting in eigen werk en van het interval infarct - hervatting, ligt de verklaarde variantie 
beduidend lager ( 5 à 10\%). Dit kan betekenen dat bij laatstgenoemde analyses niet over voldoende relevante voorspellers kon worden beschikt.

Het sukses van hervatting is in eerste instantie benaderd via het ziekteverzuim in de eerste zes maanden na hexvatting. Het verzulim in de groep jonger dan 55 jaar is niet zeer afwijkend van de landelijke cijfers: er wardt iets minder valk, mar wel iets langer verzuimd. Het ziekteverzuim in de groep van 55 jaax en ouder vertoont in vergelijking met landelijke cijfers een uitgesproken gunstig beeld. Dit moet vooral worden toegeschreven aan een uitzuivering van waO-effekten in deze groep. Er zijn nog twee opmerkingen te maken bij de registratie van het verzuim in dit onderzoek. Ten eerste is slechts gexegistreerd gedurende het eerste halfjaar na hervatting. Dit kan hebben geleid tot een onderschatting van de verzuimduur. Een tweede probleem is dat is uitgegaan van gehele en gedeeltelijke hervatting. Deze grootheden zijn echter gedurende de registratieperiode niet konstant. Wij hebben immers gezien dat volledige hervatting verliep via gedeeltelijke. De vraag is dan wat de betekenis is van een werkdag en een verzuimala. Er is hier uitgegaan van volledige verzuim- en werkdagen, omdat elk alternatief nodeloos ingewikkeld zou worden en vergelijkingen met landelijke cijfers helemal niet meer gemaakt konden worden. Het betekent ten aanzien van gedeeltelijke hervatting wel dat een relatieve onderschatting van de verzuimfrekwentie er een relatieve overschatting van de verzuimduur kan zijn ontstaan door een ondervertegenwoordiging van kort verzuim.

Een tweede benadering van het sukses van hervatting bestond uit een kombinatie van het ziekteverzulm en het oordeel van de bedrijfsarts over het welslagen van de hervatting. "Iot de geslaagde hervatters werden de nul-verzumers gerekend die bovendien nog naar het oordeel van de bedrijfsarts op een suksesvolle hervatting kohden bogen. De op deze wijze gedefinieerde groep vormt een kleine meerderheid (568) van de totale groep hervatters. In een multiple regressie-analyse bleek geslaagde hervatting samen te hangen met: gehole hervatting $(*)$, beroepsniveau $(+)$, belasting 1 in de arbedd voor infarct (-) en cardiale komplikaties (-). Vroege fysieke revalidatie heeft geen invloed op het ziekteverzulm. 


\section{Werkhervatting als subjektief herstel}

\subsection{Inlelding}

In de voorafgaande beschouwingen is werkhervatting uitsluitend benaderd met objektieve matstaven. In dit hoofdstuk zullen de subjektieve oordelen van de patiënt over het sukses van de hervatting, zijn lichamelijke konditie en zijn algemene levensomstandigheden, in relatie worden gebracht met de objektieve maatstaven. Allereerst zal worden ingegaan op de beoordeling van het sukses van de hervatting door bedrijfsarts en patient. Daarna zal worden ingegaan op de rol van hervatting voor de algehele tevredenheid van de patiërit.

5.2 Oordeel van patiënt en bedrijfsarts over sukses hervatting

Het oordeel van de bedrijfsarts over het sukses van de hervatting is reeds behandeld in hoofdstuk 4. Wanneer nu het oordeel van de patiënt naast dat van de arts wordt gelegd ontstaat het beeld zoals in tabel 5.1 is weergegeven.

Tabel 5.1: Oordeel van bedrijfsarts en patiënt over sukses hervatting

\begin{tabular}{lcccc}
\hline & \multicolumn{5}{c}{ oordeel patiënt } \\
oordeel arts & matig & redelijk & goed & totaal \\
matig & 59 & 11 & 10 & 80 (19\%) \\
redelijk & 13 & 59 & 40 & $112(26 \%)$ \\
goed & 1 & 31 & 208 & $240(56 \%)$ \\
\hline totaal & 73 & 101 & 258 & 432 \\
& $(178)$ & $(238)$ & $(60 \%)$ & $(100 \%)$ \\
\hline
\end{tabular}

$\tau_{b}=.66 ; R=.57$

Allereerst valt op te merken dat bedrijfsarts en patiënt overwegend goed te spreken zijn over het sukses van de hervatting. Het matige sukses komt zelfs relatief weinig voor. Er bestaat ook een sterk verband tussen beide oorde- 
Ien $\left(T_{h}\right)$, zij het dat de overeensteming (R) iets minder groot ${ }^{h}$ is. De gekonstateerde overeenkomst is overigens niet zo verwonderlijk, daar kan worden aangenomen dat de bedrijfsarts in de meeste gevallen op de hoogte was van de oordelen van de patiënt over het sukses van de hervatting, zijn levensomstandigheden en lichamelijke konditie. Dit hoeft overigens niet te betekenen dat de bedrijfsarts zich uitsluitend door de oordelen van de patiënt heeft laten leiden. Een analyse van de achtergronden van de respektieve oordelen is daarom een logische volgende stap.

Het probleem kan allereerst worden benaderd door de detcrminanten van de oordelen op te sporen. Daartoe is op elk oordeel afzonderlijk een multiple regressie-analyse uitgevoerd. Eerst werd een stapsgewijze regresie met vijftien variabelen uitgevoerd. Hierbij vielen door het niet bereiken van de 50 signifikantiegrens af: leeftijd, beroep, AP, komplikaties, recidief infarct, fysieke revalidatie, maatschappelijke begeleiding, zwaarte van het werk. vooral het wegvalien van beroep en angina pectoris mag opmerkelijk worden genoemd, daar beide faktoren samenhangen met de oordelen van arts en patiënt (beroep positief en AP negatief) waar het de nulde-orde korrelaties betreft. De gewone regressie-analyse met de resterende variabelen levert vrij duidelijke resultaten op. (tabel 5.2)

Tabel 5.2: Multiple regressic-analyse op het oordeel van patiënt en arts over sukses hervatting $(n=432)$ (CARGO-onderzoek)

$\begin{array}{cccc}\text { oordeel patient } & \text { oordeel arts } \\ x & \beta & r & \beta\end{array}$

tevredenheid patiënt:

- leverisomstandigheden

-lichamelijke konditie $\quad .53$

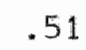

ander/eigen werk

p

1

B

\begin{tabular}{lcccc} 
aantal verzuimde dagen & -.33 & -.18 & -.30 & -.12 \\
gedeelt./geheel hervat & .42 & .15 & .50 & .22 \\
interval infarct-hervat. & -.20 & -.12 & & \\
Opnameduur & -.03 & .10 & -.06 & .07 \\
multiple korrelatie & $\mathrm{R}=.69, \mathrm{p}<.01$ & $\mathrm{R}=.73, \mathrm{p}<.01$ \\
\hline
\end{tabular}


Globaal gesproken laten arts en patiënt zich door dezelfde overwegingen leiden, zij het dat het gewicht van de overwegingen verschilt.

Voor de patient geldt dat het sukses van de hervatting sterk verweven is met zijn tevredenheid over 'Iijf' en leven. Deze clustering van tevredenheid wijst erop dat tevredenheid een betrekkelijk a-specifiek gegeven is.

ook voor het oordeel van de arts geldt dat het sukses van de hervatting in eerste instantie wordt bepald door de hem gebleken tevredenheid van de patiënt over lichamelijke konditie en levensomstandigheden.

Er zijn echter interssante verschilien in de gewichten van de overwegingen. Wanneer we ons in eerste instantie beperken tot de 'top drie', dan blijkt dat bij de patiënt tevredenheid over leven en lijf de eerste plaats delen, terwijl voor de arts de tevredenheid lijf op de eerste plaats komt. Voor de patiẽnt is belangrijk dat hij in zijn eigen of ander werk hervat, voor de arts is gehele of gedeeltelijke hervatting belangrijker. Men herkent kortom bij het oordeel van de bedrijfsarts niet alleen de rol van arts (hij gaat in eerste instantie af op de lichamelijke konditie), alsook de rol van sociaal-geneeskundige (gehele hervatting is beter dan gedeeltelijke).

opmerkelijk is voorts dat bij het oordeel van de patiënt de tijd die hij in de ziektewet heeft doorgebracht een negatieve invloed heeft, terwijl deze faktor bij de arts geen rol speelt. Het aantal verzuimde dagen geldt voor beiden als een negatieve faktor: hoe meer verzuim, hoe minder geslaagd patient en arts de hervatting vinden. Een wat merkwaardige bevinding is dat de opnameduur, die in eerste instantie geen verband onderhoudt met de oordelen, bij uitschakeling van de invloed van de andere variabelen, positief samenhangt met beide oordelen. Dit effekt kan veroorzaakt zijn door patiënten die ondanks een langere opnameduur toch nog hervatten en dan extra positief over het sukses van de hervatting oordelen. Het is echter ook mogelijk dat hier sprake is van een statistisch artefact op grond van de niet geheel lineaire relatie tussen opnamedur en oordeel (zie tabel 5.4) Tenslotte moet worden gekonstateerd dat fysieke revalidatie een opvallende afwezige is. Bij het oordeel van de patient speelt het feit of hij al dan niet vroeg gerevalideerd is geen enkele rol. Er is wel een positieve signi- 
fikante korrelatie tussen het oordeel van de arts en het gegeven of de patiënt vroeg gerevalideerd is $(r=.10)$. Dit verband houdt echter geen stand in de regressie-analysc.

Voor een tweede benadering van het vergelijken van de oordelen van arts en patient keren we terug naar tabel 5.1. Deze tabel is voor het nieuwe analyse-doel omgewerkt in een vorm, waarbij overeenstemming en diskrepantie schematisch zijn weergegeven.

Tabel 5.3: Overeenstemming en diskrepantie tussen oordeel arts en patiënt over sukses hervatting

\begin{tabular}{lcccc}
\hline & & \multicolumn{3}{c}{ oordeel patiënt } \\
\cline { 3 - 5 } oordeel arts & matig & redelijk & goed \\
\hline matig & - & -- & & -+ \\
redelijk & 0 & $(n=59)$ & 00 & $(n=61)$ \\
goed & + & & $(n=59)$ & \\
& & +- & & ++ \\
& & $(n=45)$ & & $(n=208)$ \\
\end{tabular}

De diagonaal geeft de groepen aan waar tussen arts en patiënt overeenstemming hestaat. De kategorieën boven de diagonaal zijn samengenomen in én kategorie $(-+)$, waarin de patiënt positiever oordeelt over het sukses van de hervatting dan de arts. Omgekeerd zijn de kategorieên onder de diagonal samengenomen in de kategorle $(+-)$, waarin de arts positiever is dan de patiënt. Bezlen we nu eerst een aantal belangrijke variabelen die een rol spelen bij het sukses van hervatting dan is duidelijk dat langs de diagonaal het oordeel over het sukses systematisch samenhangt met die variabelen. De diskrepante kategorieën liggen in sommige opzichten dicht bij kategorie -- en in andere meer bij 00 (tabel 5.4). 


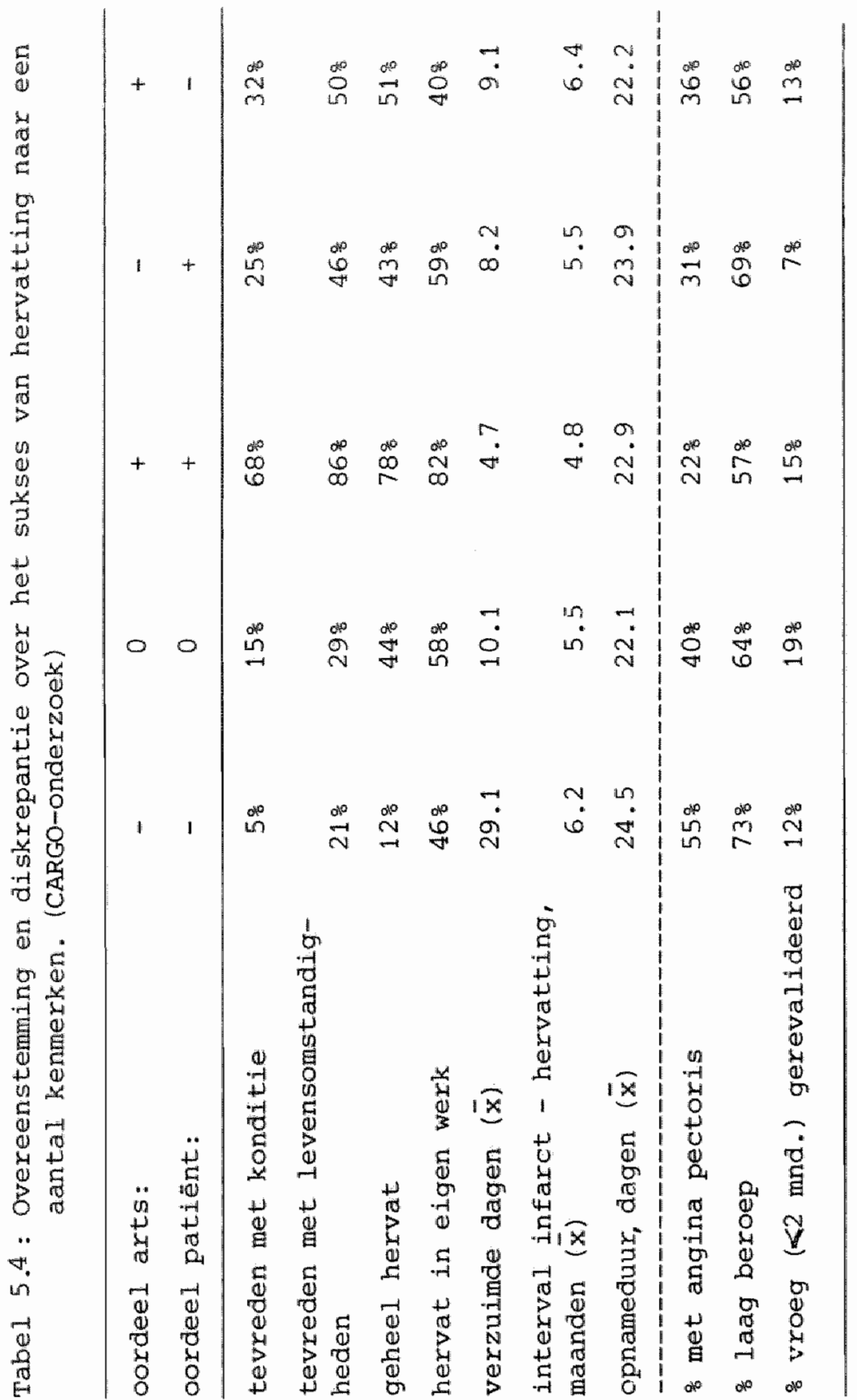


Wanneer door middel van een diskriminant-analyse gezocht wordt naar de faktoren die het best onderscheid maken tussen de drie diagonal-groepen, blijkt een beeld te ontstaan dat meer gebaseerd is op de oordeelsvorming van de bedrijfsarts dan op die van de patiënt. De volgorde van de gewichten der onderscheidende variabelen is immers nagenoeg dezelfde als bij de regressie-analyse op het oordeel van de arts (tabel 5.5).

De diskriminant-analyse is uitgevoerd net dezelfde vijftien variabelen als bij de analyses van de afzonderlijke cordelen, eerst stapsgewijs, daarna direkt met de best onderscheidende variabelen.

Tabe1 5.5: Diskriminant-analyse op de groepen warin overeenstemming bestaat tussen arts en patiënt.

faktox:

gestandaardiseerde diskriminant-koëfficiënt

tevredenheid konditie .50

tevredenheid levensomstandigheden .50

gedeelt. /geheel hervat .33

verzuimde dagen $-.29$

ander/eigen werk .27

opnameduur

interval infarct - hervatting $-.18$

1 funktie met eigenwaarde $=1.78 ;$ kan. korrelatie $=.80$; $\mathrm{p}<.001$

De gevonden diskriminant-funktie blijkt goed te onderscheiden tussen de beide uitersten van de diagonaal (- en ++ ), terwijl de middengroep (00) niet goed onderscheiden kan worden van de gunstigste kategorie.

De twee diskrepante kategorieën blijken niet goed van elkaar te kunnen worden onderscheiden. De twee faktoren die, nog enigszins onderscheid maken zijn het interval infarct - hervatting en hervatting in eigen of ander werk. Op grond van de beschikbare gegevens is het echter niet duidelijk waarop 
de diskrepanties berusten.

Tabel 5.3 is, met weglating van de middenkategorie, weer te geven als een vereenvoudigde partiele ordening.

Eiguur 3: partiele ordening van de oordelen van arts en patient over het sukses van hervatting

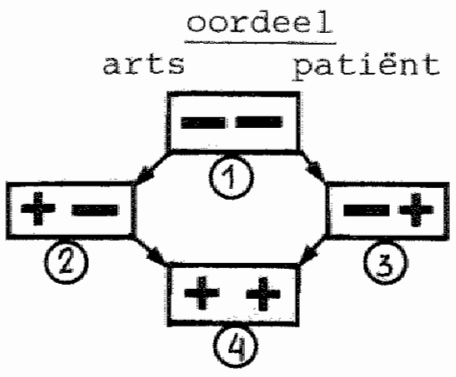

De pijlen in figuur 3 geven de transitieve relaties aan, bijvoorbeeld situatie 4 is gunstiger dan 2 en situatie 2 is weer gunstiger dan 1 . Situatie 2 en 3 zijn elk op hun eigen manier gunstiger dan 1, maar zijn onderling niet vergelijkbaar. Wel kan gesteld worden dat beide zich op het middenniveau ophouden. op basis van deze partiële ordening kunnen nu twee analyses worden uitgevoerd:

1. een vergelijking van de overgang van een negatief naar een positief oordeel van de arts onder konstant houden van het oordeel van de patiënt $(1 \rightarrow 2$ vergeleken met $3 \rightarrow 4$ ) en hetzelfde voor het oordeel van de patiënt onder konstant houden van het oordeel van de patiënt $(1 \rightarrow 3$ vergeleken met $2 \rightarrow 4)$,

2. een vergelijking van de overgangen in niveau, dus een vergelijking tussen de overgangen $1 \rightarrow 2$ en $1 \rightarrow 3$ en een vergelijking van de overgangen vanaf het middenniveau naar de gunstigste situatie $(2 \rightarrow 4$ vergeleken met $3 \rightarrow 4)$.

In Figuur 4 zijn per overgang de faktoren weergegeven die het best onderscheid maken tussen de aangrenzende kategorieen. Deze faktoren zijn verkregen uit diskriminantanalyses, die op dezelfde wijze zijn uitgevoerd als eerder beschreven voor de diagonal-groepen. De faktoren staan in volgorde van gewicht van de gestandaardiseerde diskriminant-koëficiënten (voor details zie bijlage 8 ). 
Figuur 4: Diskriminerende faktoren tussen vier beoordelingen van het sukses van hervatting.

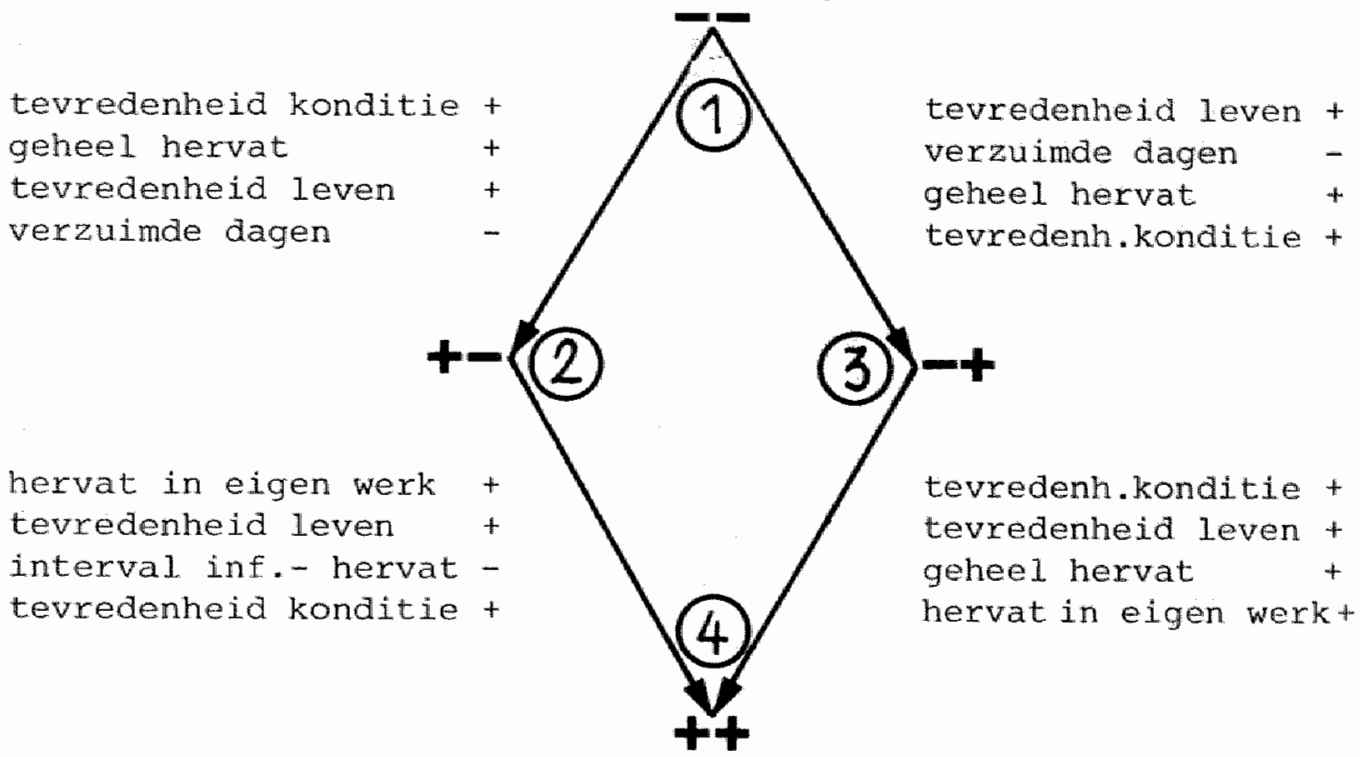

Wanneer nu allereerst de overgang $1 \rightarrow 2$ vergeleken wordt met $3 \rightarrow 4$, blijkt dat ongeacht het oordeel van de patiënt over het sukses van hervatting, de bedrijfsartsen een positiever oordeel uitspreken op basis van de hun gebleken tevredenheid van de patiënt over diens lichamelijke konditie. daarna op basis van de gebleken tevredenheid over de levensomstandigheden en de mate van hervatting. Bij konstant houden van het oordeel van de arts blijkt de patiënt positiever te oordelen over het sukses van hervatting op basis van een grotere tevredenheid met de levensomstandigheden, terwijl de grotere tevredenheid met de lichamelijke konditie op de laatste plaats komt $(1 \rightarrow 3$ vergeleken met $2 \rightarrow 4)$.

Bif de analyse van de overgangen in niveau valt op te mexken dat het ziekteverzuim alleen een rol speelt bij de overgang van het ongunstigste naar het middenniveau, zij het met verschillend gewicht voor arts en patient.

voorts valt op dat hervatting in eigen werk alleen een rol speelt bij de overgang van het middenniveau naar de gunstigste situatie, zij het ook hier met een verschillend gewicht voor arts en patiënt. De mate van hervatting speelt voor zowel arts als patiënt een rol bij de overgang van ongunstig naar middenniveau en foor de arts ook van middenniveau naar 
de ongunstigste situatie.

Samengevat komt een en ander ex op neer dat de bedrijfsarts zich bij de beoordeling van het sukses van de hervatting vrij konsistent lat lelden door de tevredenheid over de lichamelijke konditie en de mate van hervatting, terwijl. voor de patient geldt dat vanuit de ongunstigste situatie de algemene tevredenheid met het leven en het verzuim een rol speelt en vanaf het middenniveau de hervatting in eigen werk en de algemene tevredenheld een rol spelen. Tenslotte blijkt dat in vergelijking met de situatie, waarin relatief wein $\mathbf{H g}$ gehele hervatting voorkomt $(--)$ arts en patient positiever oordelen naarmate het aantal. verzumde dagen lager is en de mate van hervatting groter is. Vanaf het niveau war meer gehele hervatting voorkomt. speelt het verzuim geen rol meer, maar wordt het oordeel van beiden positiever naarmate er meer in het eigen werk hervat wordt.

5.3 Hervatting en algemene tevredenheid

In deze paragraaf zal ingegaan worden op de invloed van hervatting op de algemene tevredenheid van de hartinfarctpatiënt. Eerder gepubliceerde gegevens laten zien dat er grote verschillen zijn tussen hervatters en niet-hervatters ten aanzien van de tevredenheid over de levensomstandigheden en de lichamelijke konditie (Diederiks, 1981). Echter, de niet-hervatters zijn ook in een aantal andere opzichten in een minder gunstige situatie: ze zijn ouder, ex komt meer angüna pectoris voor en zij komen vooral uit de lagere beroepsgroepen. De vraag is dus of de niet-hervattende hartinfarctpatienten sowieso ongelukkigex zijn dan hun kollega-hervatters of dat ook de andere faktoren een rol spelen.

Teneunde deze vraag in én analyse te kunnen behandelen, is uit beide tevredenheidsmaten (algemene levensomstandigheden en konditie) én tevredenheidsindex gekonstrueerd, door sommering over de beide maten.

De sommering leidt tot zes kategorieën van tevredenheid, die zijn teruggebracht tot drie: matig tevreden, redelijk tevreden en tevreden zonder meer. Opgemerkt moet worden dat in de laatste kategoxie zich allén die patiënten bevinden 
die op beide maten de hoogste score hadden. Wanneer nu op deze algemene tevredenheidsindex hervatters en niet-hervatters vergeleken worden, blijken inderdaad aanzienlijke verschillen te bestaan (tabel 5.6).

Tabel 5.6: Algemene tevredenheid naar hervatting ( 8 )(CARGoonderzoek)

\begin{tabular}{lcc} 
& & hervat \\
tevredenheid & ja & neen \\
\hline matig & 17 & 60 \\
redelijk & 46 & 33 \\
goed & 36 & 8
\end{tabular}

Hoewel ook bij de hervattende patiënten niet iedereen helemaal tevreden is, overheerst bij de niet-hervatters de matige tevredenheid.

Door middel van een multiple regressie-analyse is nagegaan of hervatting inderdaad een zo dominerende plaats inneemt in de bepaling van de tevredenheid en welke rol andere faktoren spelen. In de stapsgewijze analyse vielen af: leeftijd, recidief infarct, cardiale komplikaties, zwaarte van het werk vobr infarct en matschappelijke begeleiding. Het is vooral opvallend dat leeftijd afvalt, hoewel er een nulde-orde korrelatie van -.16 met de tevredenheid bestaat. Het resultaat van de gewone, hierna uitgevoerde regressie-analyse, vindt men in tabel 5.7 .

Tabel 5.7: Multiple regressie-analyse op de algemene tevredenheidsindex (CARGO-onderzoek).

\begin{tabular}{lcc}
\hline & $r$ & $\beta$ \\
\hline niet hervat/hervat & .43 & .31 \\
angina pectoris & -.32 & -.19 \\
beroep & .28 & .16 \\
fysieke revalidatie & .12 & .09 \\
opnameduur & -.13 & -.09 \\
\hline multiple korrelatie & $\mathrm{R}=.51, \mathrm{P}<.01$ & \\
\hline
\end{tabular}


Uit deze analyse blijkt dat hervatting inderdaad de dominerende faktor is in de bepaling van de tevredenheid. Echter, ongeacht hervatting blijken angina pectoris en opnameduur een negatieve, en beroep en revalidatie een positieve rol te spelen. Hoewel het positieve effekt van vroege fysieke revalidatie gexing is in vergelijking met de invloed van de hervatting op de tevredenheid, moet toch gekonstateerd worden dat een zekere konsistentie kan worden toegekend aan de positieve effekten van vroege fysieke revalidatie op hervatting op zich, de mate van hervatting en de algemene tevredenheid.

\subsection{Samenvatting en diskussie}

Het welslagen van de hervatting wordt door bedrijfsarts en patient overwegend positief beoordeeld. Bovendien bestaat tussen beide oordelen een vrij behoorlijke mate van overeenstemming. De oordelen van arts en patiënt blijken wel van elkaax verschillende achtergronden te hebben: bij de patient spelen de tevredenheid over de levensamstandigheden en over de lichamelijke konditie de hoofdrol, daarna blijkt het oordeel over het sukses van hervatting te worden beinvioed door het al of niet hervatten in eigen werk. Bij de arts staat de hem gebleken tevredenheid over de lichamelijke konditie van de patiënt voorop, dan die over de levensomstandigheden en daarna het al of niet geheel hervatten van het werk. Het blijkt voorts dat het aantal verzulimde dagen een negatieve rol speelt bij de beoordeling van het sukses door arts én patient, wamneer de situatie met weinig gehele hervatting vergeleken wordt met die waren een middelmatig niveau var gehele hervating gexealseerd wordt. Wanneer deze laatste situatie op zijn beurt weer vergeleken wordt met die warln een flinke meerderheid van de patienten geheel hervat heeft, is de hervatting in het eigen werk, bij de patiënt meer dan bij de arts, van belang voor de totstandkoming van een positieve beoordeling van het sukses van hervatting.

Bij deze konklusies moet echter worden verdiskonteerd, dat het oordeel van de arts niet onafhankelijk van dat van de patient tot stand is gekomen. Het is natuurlijk mogelijk dat een in dit opzicht onafhankelijke meting andere resultaten zou hebben opgeleverd. Anderzijds is het echter onredelijk te verwachten dat de bedrijfsarts een cordeel over 
het sukses van de hervatting zou kunnen uitspreken, zonder daar op enigerlei wijze het oordeel van de patient zelf in te betrekken. Bovendien blijkt dat, ook al is het oordeel van de arts gekleurd door dat van de patiënt, de achtergronden van de beide oordelen van elkaar verschillen. $\mathrm{Bij}$ een analyse in de groep hervatters plus niet-hervatters naar de faktoren die samenhangen met algemene tevredenheid, blijkt het al of niet weer aan het werk zijn de belangrijkste faktor te zijn. Los van werkhervatting beinvloeden angina pectoris en opnameduur de tevredenheid negatief, terwijl beroep en vroege fysieke revalidatie een positieve invloed blijken te hebben. De ziekenhuisopname en de fysieke revalidatie zijn gebeurtenissen die in het algemeen maanden vóordat de tevredenheid is vastgesteld hebben plaatsgevonden, zodat het onaannemelijk is de gevonden relaties toe te schrijven aan (on) dankbaarheidseffekten. Vroege fysieke revalidatie heeft blijkbaar een positieve invloed op de algemene tevredenheid die enkele maanden later is vastgesteld, langere opnameduren hebben daarentegen juist een negatief effekt. Zoals al eerder is opgemerkt hangt opnameduur samen met cardiale komplikaties en met het type ziekenhuis waarin de opname plaats vond. Het effekt van de komplikaties is echter al verwerkt in de regressie-analyse, zodat kan worden verondersteld dat vooral het type ziekenhuis van invloed is. Kort gezegd komt dit erop neer, dat het in dit opzicht beter is in een academisch ziekenhuis te zijn opgenomen dan in een perifeer ziekenhuis. Omdat angina pectoris circa drie maanden na infarct werd vastgesteld, kan ook worden gesproken van een voorspellende waarde van deze faktor voor de tevredenheid enkele maanden later. Dit is te verklaren uit het feit dat patiënten met angina pectoris in het algemeen een slechtere prognose hebben.

\subsection{Nabeschouwing CARGO-onderzoek}

Geeft het onderzoek nu uitsluitsel over de vier aspekten, namelijk over mate, wijze en sukses van werkhervatting. na hartinfarct en over de daarmee samenhangende faktoren? onzes inziens levert het onderzoek als geheel redelljk bevredigende antwoorden op. De beperkende faktoren zijn grotendeels terug te voeren op de aard van de gegevens, die 
soms vrif globaal zijn en voor een deel op de opzet van het onderzoek, die een in verschillende opzichten heterogene populatie heeft opgeleverd. Dit latste is overigens juist geen bezwaax voorzover het de pure beschrijving betreft van mate en wijze van hervatting.

Men moet zlch overigens realiseren dat voor het eerst een lande Lljke indruk is verkregen. Het is natuurlijk mogelijk dat de deelnemende bedrijfsartsen van de 42 betrokken bedrijfsgeneeskundige diensten een positieve selektie vormen wat betreft de betrokkenheid bij de onderhavige problematiek. Gesteld dat deze betrokkenheld leidt tot grotere aktiviteit ten aanzien van werkhervatting, dan zouden de cijfers uit dit onderzoek een geflatteerd beeld geven. Het percentage mannen dat het werk hervat ligt in elk geval binnen de grenzen die men kan trekken op basis van een aantal lokale onderzoeken.

De beoordeling van de resultaten is echter problematischer bij wat als de crux van het onderzoek mag worden beschouwd, namelijk bij de vraag naar de effekten van fysieke revalidatie op de hervatting en sukses van hervatting. Revalidatie blijkt verre van een eenduidige faktor te zijn. Uiteraard was reeds bij de aanvang van het onderzoek duldelijk dat voor heel Nederland geen standaard revalidatieprogramma bestaat, maal dat de variatie zo groot zou zijn als uit het onderzoek bleek, werd niet vermoed. Deze overwegingen doen overigens aan het resultaat dat vroege fysieke revalidatie en positief effekt heeft op hervatting op zichzelf niets af. De problemen doen zich voor wanneer een nadere betekenis aan dit resultaat moet worden gegeven. Want, wat betekent vroege revalidatie in termen van het soort programma? En: voor welke patiênten is deze revalidatie dan positief? In elk geval is redelijk staande te houden dat vroege fysieke revalidatie, variërend van een simpel trainingsprogramma bij de behandelend specialist tot en met de wat complexere programma"s in de centra, een positief effekt heeft. Het be langrijkste argument is gelegen in de konsistentie van het effekt op respektievelijk het hervattingspercentage, de mate van hervatting en de algemene tevredenheid van de patiènt. Echter, omdat het onderzoek geen gekontroleerde experimentele opzet had, kan een positieve selektie van de vroeg gexevalideerden niet worden uitgesloten. Wel zijn de groepen die vroeg en niet gerevalideerd werden vergelijk- 
baar qua leeftijd, beroep, angina pectoris en cardiale komplikaties. De groep die laat gerevalideerd wordt is wat deze faktoren betreft niet met beide andere groopen vergelijkbaar. Voor deze groep patiënten, die vooral an de revalidatiecentra wordt aangeboden, geldt dat hervatting al problematisch is geworden, terwijl in deze groep bovendien relatief meer patienten met komplikaties voorkomen. Wat betreft het sukses van de hervatting is het van belang hier te memoreren dat uit dit onderzoek niet te konkluderen valt dat hartinfarctpatiënten die het werk hebben hervat, een ongunstig ziekteverzuim te zien zouden geven. Hierbij dient te worden aangetekend, dat de registratieperiode slechts een half jaar bedroeg. Het is onzeker wat het resultaat op langere termijn zal $\mathrm{zijn}$, temeer daar twee tegenstrijdige redeneringen kunnen worden gevolgd. Men kan stellen dat juist in de beginfase van hervatting de verzuimnoodzaak verhoogd zal zijn, daar in deze fase de konfrontatie met de eisen van werk het sterkst zal zijn; aan de andere kant is het niet onredelijk te veronderstellen dat, na de aanvankelijke vreugde over de hervatting, op den duur toch problemen ontstaan. Als we echter uitgaan van de huidige gegevens, kan gesteld worden dat er vooralsnog geen redenen zijn aan te nemen dat hartinfarctpatiënten een hoog ziekteverzuim hebben.

Bedrijfsartsen en patiënten zijn in meerderheid goed te spreken over het sukses van de hervatting. Bij de patiënten is de tevredenheid over de hervatting nauw verweven met die over levensomstandigheden en lichamelijke konditie. De verwevenheid duidt erop dat tevredenheld een a-speciflek kenmerk is. Gekombineerd met de bevinding dat hervatting op zich de belangrijkste determinant van algemene tevredenheid is, leidt dit tot de konklusie dat werken als een soort kristallisatiepunt voor tevredenheid fungeert. 


\section{De invloed van revalidatie op herstel: Resultaten van het leidse onderzoek.}

\subsection{Inleiding}

Het Leidse onderzoek biedt, in tegenstelling tot het CARGOonderzoek, de mogelijkheid in een experimentele opzet de effekten van revalidatie op zowel fysiek, psychisch en sociaal herstel te onderzoeken. Nadelen van het Leidse onderzoek zijn de geringe omvang van de onderzoeksgroep en het feit dat deze afkomstig is uit een specifieke populatie, die niet noodzakelijkerwijs een afspiegeling behoeft te zijn van hersteliende hartinfarctpatiënten. Het is daarom van belang de resultaten van dit onderzoek zoveel mogelijk te vergelijken met gegevens uit andere bronnen.

In dit hoofdstuk komen allereerst een aantal enkelvoudige maten van fysiek, psychisch en sociaal herstel aan de orde. Daarna zal worden ingegaan op de invloed van de revalidatie op de partner van de patiënt. Tenslotte zal een samenvattende analyse van de resultaten worden gepresenteerd.

\section{2 objektief fysiek herstel}

Inspanningstolerantie

Als eerste mat voor fysiek herstel is hier gekozen voor de maximale inspanningstolerantie (Watt max). Deze werd bepaald op de fietsergometer met een geleidelijk opklimmende belasting -10 watt per minuut- in zittende houding. Nu is het maximum bij coronair-patiënten niet op dezelfde wijze te bepalen als bij gezonden. Het naximum wordt in de eerstgenoemde groep veelal bepaald door het ondraaglijk worden van verschijnselen als pijn op de borst en kortademigheid. Men spreekt hier dan ook liever van de symptom limited physical working capacity, dat wil zeggen het maximum wordt op subjektieve gronden bepaald. Het is dan wel van belang dat de patlënten worden aangemoedigd zover als mogelijk is, door te gaan. De onderzoeker kan te allen tijde zelf de fietsproef afbreken, bijvoorbeeld op geleide van het inspannings-ECG. Dit verschijnsel heeft zich in dit onderzoek niet voorgedaan. Het feit dat het maximum subjektief bepaald wordt doet de vraag rijzen of wel altijd het 'echte' 
maximum wordt gehald en of ook niet de motivatie van de patiënt een belangrijke rol kan spelen. Meettechnisch gaat het dan om de vraag of de resultaten van een op deze wijze uitgevoerde fietsproef repliceerbaar zijn. Enkele jaren geleden is in Leiden een onderzoek gedaan on deze vraag te kunnen beantwoorden. Met één dag tussenpexiode zijn 130 hartinfarctpatiënten getest. Het resultaat van deze replicatie is een hertest-betrouwbaarheid van $.89 \mathrm{en}$ een standaardmeetfout van 10 watt. Dit resultat is vergelijkbaar met dat van zeer goede psychologische tests en een stuk beter dan replicaties van bij voorbeeld bloeddrukmetingen. Het resultaat is al met al bevredigend te noemen, terwijl de standaardmeetfout aangeeft dat niet zinvol gesproken kan worden over verschillen kleiner dan 10 watt.

In het huidige onderzoek is de inspanningstolerantie vier maal gemeten: $3,6,12$ en 24 maanden na hartinfarct, voor zowel revalidatie als kontrolegroep. Het resultaat vindt men in figuur 5.*)

Figuur 5: Het verloop van de maximale inspanningstolerantie

Watt in revalidatie- en kontrolegroep.

\section{$\max$}

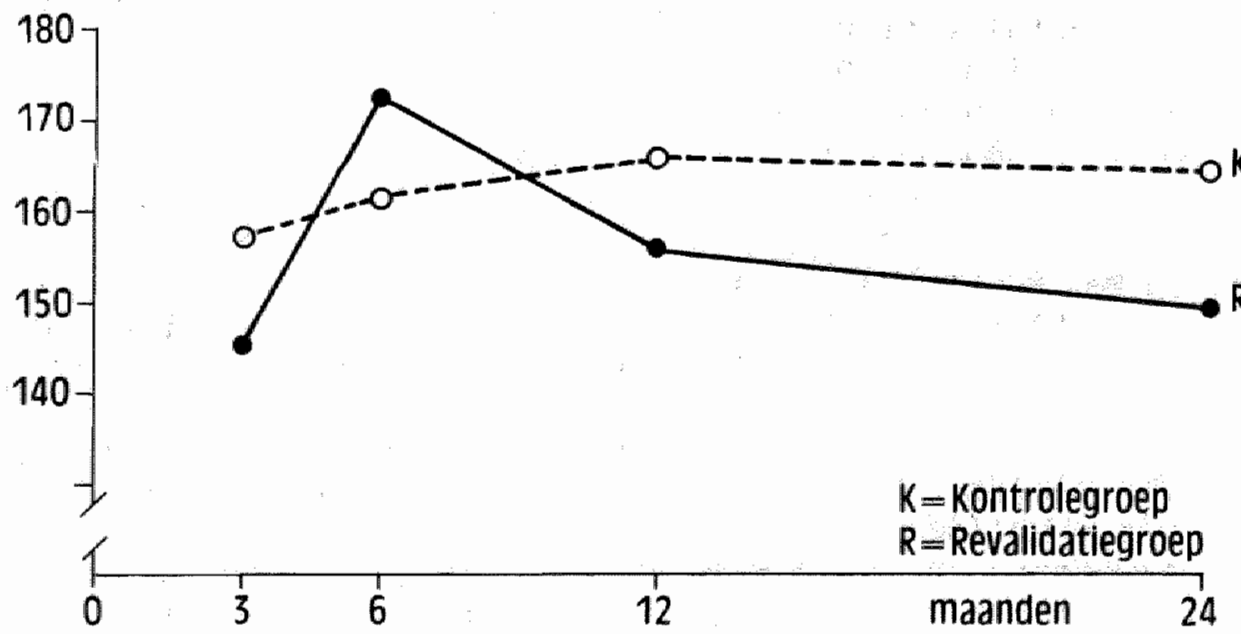

*) Verdelingsgegevens van de grafisch weergegeven variabelen vindt men in bijlage 9 . 
De kontrolegroep begint en eindigt op een niveau dat gemiddeld 12 a 15 watt hoger 1 igt dan in de revalidatiegroep. De revalidatie, die tussen een en zes maanden plaats vond. bewerkstelifgt een trainingseffekt van ruim 18:.

In de vergelijkingsgroep (zie pag. 61) van de in 1973 te Katwijk gerevalideerde patienten $(n=24)$ steeg de inspanningstolerantie van 158 naar 182 watt, een trainingswinst van 15\%. In de periode tussen drie en zes maanden is het verschil in verandering tussen revalidatie- en kontrolegroep signifikant (Mann-Whitney u-test: $z=4.37$, p .001 ). Echter, zes maanden na revalidatie is de trainingswinst bijna geheel verdwenen. Ook hier is het verschil in verandering tussen revalidatie- en kontrolegroep signifikant $(z=-3.79, p<.01)$.

De konklusie is dus dat de revalidatie slechts een kortdurende trainingseffekt heeft. Een half jaar na de revalidatie is deze winst weer verdwenen.

Om de vermelde resultaten beter te kumnen beoordelen moet worden stilgestaan bij de bereikte maximale hartfrekwenties. Een trainingseffekt is immers overtuigender wanneer dit bereikt wordt bij ongeveer dezelfde gemiddelde maximale hartfrekwenties. Voor de beoordeling van de maximale hartfrekwentie is het echter weer nodig inzicht te hebben in het aantal patiënten met angina pectoris en met $B$-blokkerende medikatie. De diagnose angina pectoris (AP) is gebaseerd op een positieve anamnese van de typische pijn op de borst en op het positieve effekt van nitroglycerine. Tabe1 6.1 geeft een overzicht van de maximale hartfrekwenties, de aantallen $\mathrm{AP}+$ en $\mathrm{B}+$-patienten in revalidatiekontrole- en vergelijkingsgroep.

Uit deze tabel blijkt allereerst dat in de revalidatiegroep, in vergelijking met de kontrolegroep, lagere frekwenties worden gerealiseerd, behalve zes manden na infarct. Het trainingseffekt blijkt voorts mede te worden toegeschreven aan een stijging van de maximale hartfrekwentie: de kontrolegraep blijft gemiddeld konstant, terwijl in de revalidatiegroep een gemiddelde stijging van $6 \mathrm{sl} / \mathrm{min}$ optreedt tussen arie en zes maanden. De vergelijkingsgroep blijkt de gunstigste groep te zijn, mede door het kleinere aantal patiënten met $\beta$-blokkerende medikatie. 
Tabel 6.1: Het verloop in de maximale hartfrekwentie ( $\mathrm{sl} / \mathrm{min}$ ) en aantallen patienten met angina pectoxis en $B-$ blokkerende medikatie in revalidatie-, kontroleen vergelijkingsgroep.

\begin{tabular}{|c|c|c|c|c|c|}
\hline maanden na MI & & 3 & 6 & 12 & 24 \\
\hline $\begin{array}{l}\text { revalidatie } \\
(\mathrm{n}=24) \\
\\
\text { min. }\end{array}$ & $\begin{array}{l}\operatorname{HF}(\bar{x}) \\
\text { s.d. } \\
-\max .\end{array}$ & $\begin{array}{l}\frac{147.2}{(21.5)} \\
95-185\end{array}$ & $\begin{array}{r}\frac{153.1}{(20.4)} \\
105-187\end{array}$ & $\begin{array}{c}\frac{145 \cdot 3}{(21 \cdot 5)} \\
100-170\end{array}$ & $\begin{array}{r}\frac{147 \cdot 1}{(19 \cdot 3)} \\
105-170\end{array}$ \\
\hline $\begin{array}{l}\text { kontrale } \\
(n=27) \quad \min .\end{array}$ & $\begin{array}{l}\operatorname{HF}(\bar{x}) \\
\text { s.d. } \\
\text {-max. }\end{array}$ & $\begin{array}{l}\frac{153.2}{(23.6)} \\
98-200\end{array}$ & $\begin{array}{l}\frac{153.3}{(24.5)} \\
98-199\end{array}$ & $\begin{array}{l}\frac{149.4}{(20.1)} \\
100-176\end{array}$ & 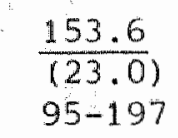 \\
\hline $\begin{array}{l}\text { vergelijking } \\
(n=24) \\
\text { min. }\end{array}$ & $\begin{array}{l}\operatorname{HF}(\bar{x}) \\
s \cdot d . \\
-\max .\end{array}$ & $\frac{161.5}{(21.0)}$ & $\begin{array}{r}\frac{161.0}{(20.2)} \\
115-198\end{array}$ & & \\
\hline rovalidatie & $\begin{array}{r}\mathrm{AP}+ \\
\mathrm{B+}\end{array}$ & $\begin{array}{l}7 \\
7\end{array}$ & $\begin{array}{r}9 \\
10\end{array}$ & $\begin{array}{l}9 \\
9\end{array}$ & $\begin{array}{r}8 \\
10\end{array}$ \\
\hline kontrale & $\begin{array}{c}\mathrm{AP}+ \\
\mathrm{B}+\end{array}$ & $\begin{array}{r}10 \\
6\end{array}$ & $\begin{array}{l}9 \\
7\end{array}$ & $\begin{array}{l}9 \\
7\end{array}$ & $\begin{array}{r}5 \\
10\end{array}$ \\
\hline vergelijking & $\begin{array}{c}\mathrm{AP}+ \\
\mathrm{B}+\end{array}$ & $\begin{array}{l}5 \\
3\end{array}$ & $\begin{array}{l}5 \\
4\end{array}$ & & \\
\hline
\end{tabular}

De konklusie moet zijn dat het gevonden trainingseffekt gerelativeerd wordt door de,tussen drie en zes maanden, gestegen maximale hartfrekwentie in de revalidatiegroep. Verondersteld kan worden dat in deze groep bij de eerste meting niet alle patiënten tot het subjektieve maximum zijn gegaan.

\section{Aktiviteitenniveau}

De tweede benadering van het fysieke herstel gaat uit van de mate van fysieke aktiviteiten in het dagelijks leven. Deze werd bepaald aan de hand van een vereenvoudigde versie van de metode van der sluijs (1972). Het aktiviteitenniveau van een gemiddelde doordeweeksedag wordt uitgedrukt in de aktiviteitsgraad: het kotiënt van het bruto-energieverbruik als gemiddelde over de dag vanaf het opstaan tot aan het 
avondeten en het basaalmetabolisme, beide in $\mathrm{ml} \mathrm{O}_{2} / \mathrm{min}$. De aktiviteitsgraad is dus een dimensieloos getal en geeft aan hoeveel maal de warde van de basale stofwisseling door het energieverbruik wordt overschreden. De laagste waarde is dan per definitie 1, de hoogste waarde kan bij zware inspaning over langere duur 5 worden (v.d. Sluijs en Dirken, 1970).

De aktiviteitsgraad is in dit onderzoek bepaald op 3,6 ,

12 en 24 maanden na infarct en bovendien -retrospektief-voor de periode vlak vóór infarct. Figuur 6 geeft het verloop in de aktiviteitsgraad aan voor beide groepen.

Figuur 6: Het verloop van de aktiviteitsgraad in revalidatieen kontrolegroep

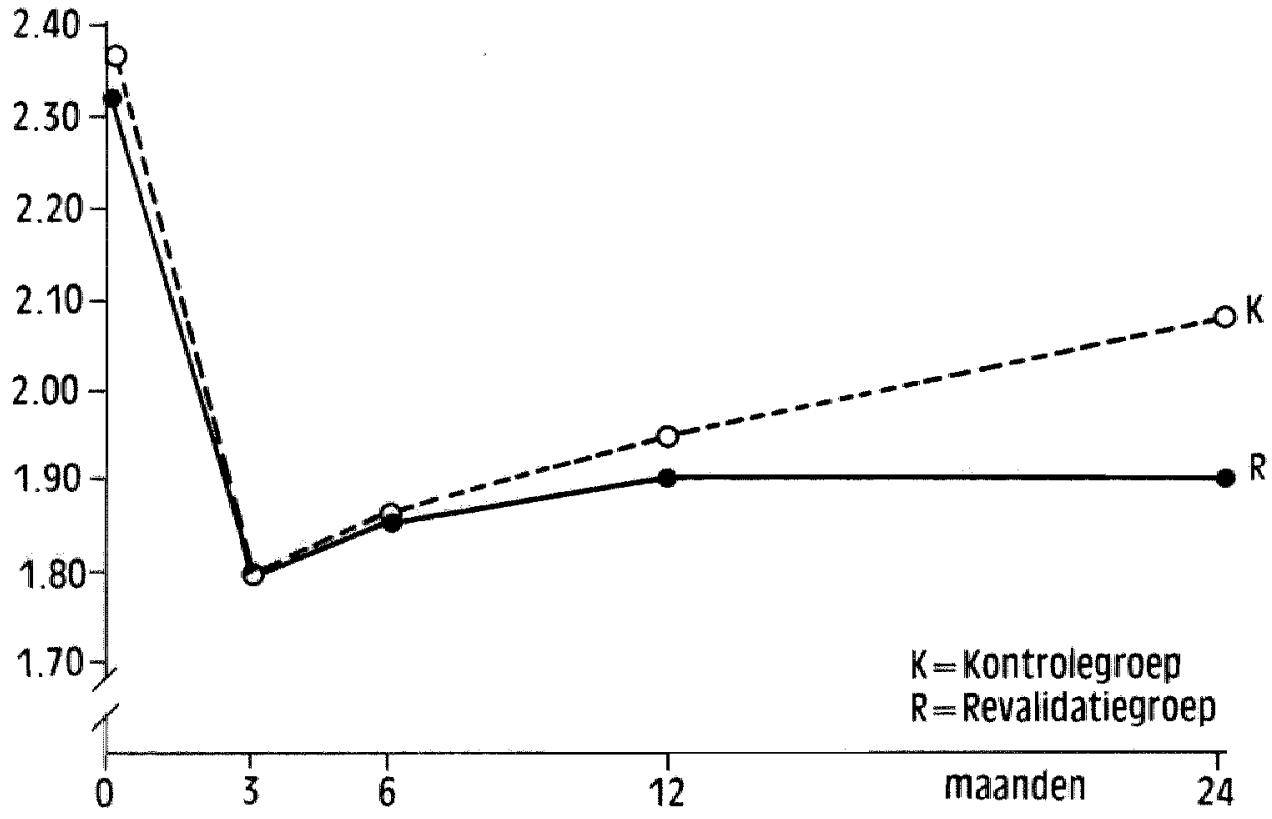

Het niveau van aktiviteiten voór het infarct blijkt voor revalidatie- en kontrolegroep ongeveer even hoog te liggen. Dit niveau ligt lets onder dat van de gemiddelde industrie- 
arbeider (v.d. Sluijs en Dirken, 1970). Drie maanden na infarct is de aktiviteitsgraad in beide groepen sterk gedaald tot een niveau dat slechts even boven dat van een kantoorbediende (1.62) 1igt. Zes manden na infarct is de aktiviteitsgraad in beide groepen gemiddela evenveel gestegen, daarna stijgt de kontrolegroep meer dan de revalidatiegroep om tenslotte op een hoger niveau te eindigen. Het verschil in stijging is echter niet signifikant, noch tussen 6 en 12, noch tussen 12 en 24 maanden na infarct. Revalidatie heeft dus geen invloed op het aktiviteitenniveau, revalidatie- en kontrolegroep gedragen zich het eexste halfjaar na infarct vrijwel hetzelfde, terwijl de aktiviteitsgraad van de kontrolegroep zich daarna zelfs iets gunstiger ontwikkeld. In het algemeen kan worden opgemerkt, dat het aktiviteitenniveau van deze totale groep hartinfarctpatiënten drie maanden na infarct sterk gedaald is ten opzichte van dat van vór het infarct. Gezien het felt dat op dit tijdstip de spreiding om het gemiddelde gering is, kan worden gesproken van een soort bodemniveal, dat voor het merendeel der patiënten geldt isie ook: v.d. Sluijs et al., 1979). Bovendien blijkt dat, gemiddeld genomen, het niveau van vór het infarct niet meer bereikt wordt.

Vanzelfsprekend kan worden aangenomen dat het verloop in de aktiviteitsgraad mede beinvloed wordt door het al dan niet hervatten van het werk. Op dit punt zal worden teruggekomen in hoofdstuk 7 .

\section{3 objektief psychisch herstel}

Subjektieve belasting

Als eerste benadering voor de beschrijving van het objektheve psychische herstel is hier gekozen voor de subjektieve belasting-schaal van Josten (1972). Deze schaal beoogt de hinder te meten die de patiënt ondervinat bij het ontplooien van de dagelijkse aktiviteiten. De gemiddelde score van deze 53 items tellende schal is voor gezonden 12, terwijl de scores van hartinfarctpatiënten gemiddeld twee maal zo hoog liggen (Josten, 1972).

Tabel 6.3 geeft het verloop van de subjektieve bealsting (SB) voor revalidatie-, kontrole- en vergelijkingsgroep aan. 
Tabel 6.3: Het verloop in de subjektieve belasting in revalidatie-, kontrole- en vergelijkingsgroep

maanden na MI:

3

6

12

24

\begin{tabular}{|c|c|c|c|c|c|}
\hline \multirow[t]{2}{*}{ revalidatie } & $\bar{x}$ & 22.9 & 25.2 & 24.9 & 23.0 \\
\hline & s.a. & $(10.0)$ & $(\overline{12.1})$ & $(\overline{12.1})$ & $(\overline{12.5})$ \\
\hline min & $-\max$. & $2-40$ & $3-51$ & $7-43$ & $6-44$ \\
\hline kontrole & $\bar{x}$ & 20.9 & 22.1 & 20.9 & 21.9 \\
\hline & $s . d$. & $(\overline{11.2})$ & $(\overline{12.6})$ & $(\overline{13.4})$ & $(\overline{12.4})$ \\
\hline min & $-\max$ & $5-41$ & $4-41$ & $5-40$ & $5-40$ \\
\hline \multirow[t]{2}{*}{ vergelijking } & $\bar{x}$ & 19.7 & 20.1 & & \\
\hline & s.a. & $(8.7)$ & $(\overline{11.3})$ & & \\
\hline min & $-\max$. & $9-35$ & $6-47$ & & \\
\hline
\end{tabular}

ovex het geheel genomen blijkt niet veel te veranderen in de SB-scores, de gemiddelden pex groep liggen rond dezelfde waarde. De scores in de revalidatie-groep liggen systematisch, maar niet signifikant, boven die van de kontroleen vergelijkingsgroep. Wanneer gekeken wordt naar het aantal patiënten dat meer dan twee maal de standaardmeetfout $(=3)$, in positieve of negatieve richting verandert, verkrijgt men een beeld dat overeenkomt met dat van de gemiddelden. Tussen drie en zes maanden vinden relatief de meeste veranderingen plaats: in zowel revalidatie- als kontrolegroep stijgen 7 en dalen 3 patiënten. Tussen de andere meettijdstippen blijft $3 / 4$ van de patiënten konstant, dat wil zeggen verandert niet meer dan \pm 6 .

De konklusie is dus dat de subjektieve belasting een betrekkelijk konstant gegeven is, dat niet door de revalidatie wordt beinvloed. Ook kan hier gekonkludeerd worden dat het gestegen prestatievermogen niet gepaard gegaan is met een daling van de subjektieve belasting. Transversal bestaat weliswaar een zwak negatief verband tussen de $\mathrm{SB}$ en het maximale inspanningsvermogen $(r=-.25)$, maar er is geen verband tussen $\Delta S B$ en $\Delta$ wattmax.

Gepercipieerde inspanningstolerantie Tegen het gebruik van de SB kan als bezwaar worden aangevoerd dat deze minder geschikt is om een psychisch herstel 
te konstateren wanneer men onmiddelisjk na de interventie, zoals hier gebeurd is, de test afneemt. De patiënten die gerevalideerd zijn hebben immers nog niet veel gelegenheid gehad de subjektieve belasting in het dagelijks leven na de revalidatie te ervaren. Om dit probleem te omzeilen is een test ontworpen die tracht te meten wat de patient aan lichamelijke aktiviteiten denkt te kunnen ontplooien. Hiertoe werden aan de patiënten zeven aktiviteiten voorgelegd, zoals én of meerdere trappen oplopen, het gedurende enige tijd dragen van een koffer en boodschappentas en het gedurende enige tijd hardlopen, met de vraag of zij zichzelf in staat achtten deze aktiviteiten te kunnen ondernemen. Uit de zeven items bleek een uniaimensionele kumulatieve schaal te kunnen worden gekonstrueerd, die de naam perceived exercise tolerance (PET)-schal kreeg (Dlederiks en Weeda, 1977). De psychometrische eigenschappen van deze schaal zijn samengovat in bijlage 10. De score loopt van 1 tot en met 6 , de score 1 geeft aan dat de patient zichzelf in staat acht één trap te lopen, terwijl een score 6 betekent dat de patiënt zichzelf in staat acht alle genoemde aktiviteiten an te kunnen. Door de patiënten werd het over 50 meter hardlopen als de zwaarste aktiviteit bestempeld. Als het zo is dat door revalidatie het zelfvertrouwen wordt verbeterd, dan mag men verwachten dat na een revalidatie warin het prestatievermogen is verbeterd, de patiênten zich tot meer in staat achten.

Een analyse van het verloop in de PET-scores laat het echter niet toe deze veronderstelling als gewettigd te beschouwen (tabe1 6.4). Weliswaar treedt tussen drie en zes maanden een stijging op in de revalidatiegroep, maax deze stijging is niet signifikant, terwijl bovendien in de kontrolegroep dezelfde verandering valt te konstateren.

Weer valt op dat de kontrolegroep zich in gunstige zin onderscheidt van de revalidatiegroep.

De konklusie is dat revalidatie geen invloed heeft op de gepercipieerde inspanningstolerantie, casu quo dat de eerder gekonstateerde trainingswinst geen aanleiding is voor de gerevalideerden zichzelf tot meer in stat te achten.

Tevens kan worden vastgesteld dat gemiddeld genomen, de PET-scores na zes manden op hetzelfde niveau blijuen. 
Tabel 6.4: Het verloop in de PET-scores in revalidatie- en kontrolegroep.

\begin{tabular}{|c|c|c|c|c|c|}
\hline \multicolumn{2}{|c|}{ maanden na $M I$ : } & 3 & 6 & 12 & 24 \\
\hline revalidatie & $\begin{array}{r}\bar{x} \\
\text { s.d. }\end{array}$ & $\frac{3.3}{(1.6)}$ & $\frac{3.8}{(1.8)}$ & $\frac{3.7}{(1.6)}$ & $\frac{3.8}{(1.8)}$ \\
\hline kontrole & $\begin{array}{r}\bar{x} \\
\text { s.d. }\end{array}$ & $\frac{3.8}{(1.6)}$ & $\frac{4.2}{(1.7)}$ & $\frac{4.3}{(1.6)}$ & $\frac{4.3}{(1.6)}$ \\
\hline
\end{tabular}

Minimum en maximum voor alle metingen: 1-6

6.4 objektief sociaal herstel

Inleiding

Social herstel zal hier benaderd worden vanuit de drie gebieden werk, gezin en vrije tijd. Voorts zal worden ingegaan op veranderingen in de dagindeling. Bij de eerste benadering gaat het om de aard van de sociale aktiviteiten, bij de tweede om de duur en volgorde van die aktiviteiten. De reeds behandelde aktiviteitsgraad zegt iets over de fysieke zwaarte van de aktiviteiten samen.

Werkhervatting

De terugkeer naar werk behoorde niet tot de voorafgekozen kriteria aan de hand waarvan de effekten van revalidatie zouden worden geëvalueerd. Doordat de randomisering plaats heeft gevonden met inachtname van leeftijd, angina pectoris en beroep, zijn de belangrijkste determinanten voor hervatting uitgeschakeld en zijn geen belangrijke verschilien tussen revalidatie- en kontrolegroep te verwachten. Het is echter duidelijk dat niet zinvol gesproken kan worden over psychisch en sociaal herstel, zowel objektief als subjektief, zonder werkhervatting in de beschouwingen te betrekken. Het verloop van de werkhervatting tijdens de onderzoekperiode laat zien dat er weliswaar geen grote, en ook geen signifikante, verschillen optreden, maar dat de gerevalideerde groep $z i c h$ op een paar punten negatief onderscheidt van de kontrolegroep (tabel 6.5 ). 
Tabel 6.5: Het verloop van de werkhervatting in revalidatieen kontrolegroep

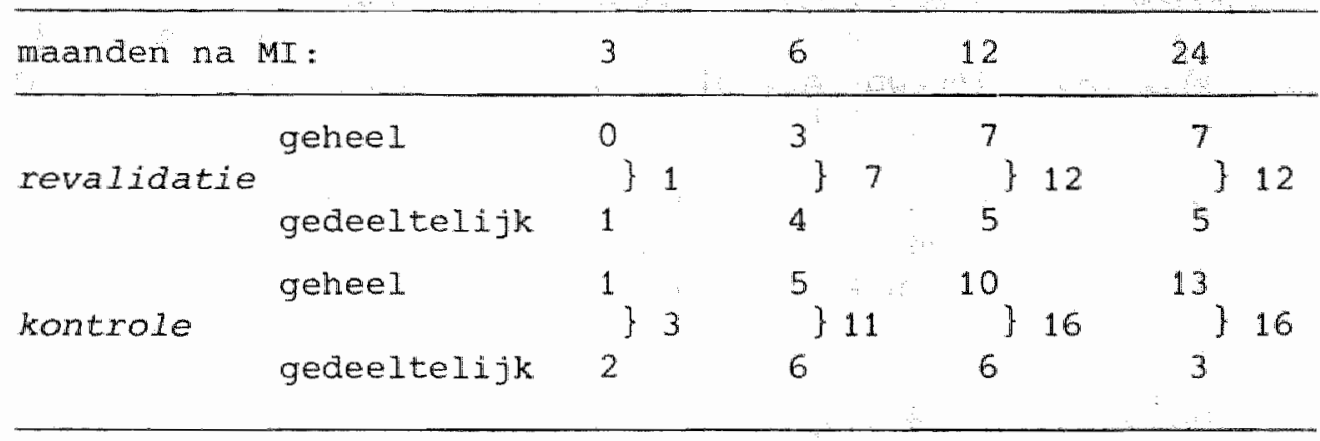

Het uiteindelijke percentage dat het werk hervat ligt in de gerevalideerde groep lagex dan in de komtrolegroep 150 tegen 59\%), terwijl in de kontrolegroep ook meer gehele hervatting gerealiseerd wordt. Tevens is sprake van een uitsteleffekt door revalidatie, hetgeen eerder werd gevonden door vermeulen et al. (1978) in een overigens vroeger gestarte revalidatie.

Het hervattingspercentage van de gehele groep ligt met zijn 55\% wat aan de lage kant. Wellicht zijn hiex de relatieve ondervertegenwoordiging van patienten met hoge beroepen (zie hoofdstuk 3.2) en de weinig rooskleurige ekonomische situatie in de Leidse regio hier debet aan.

Aktiviteiten in het gezin

Als indikator voor de aktiviteiten in het gezin is gekozen voor de participatie van de man aan huishoudelijke taken, omdat deze in het algemeen de best te omschrijven en meest konstante elementen zijn van gezinsaktiviteiten. In dit onderzoek is uitgegaan van twalif huishoudelijke taken, gebaseerd op het onderzoek van Blok-v.d. Voort (1977). De participatie van de man is uitgedrukt als proportie van de taken die de man voor zijn rekening zegt te nemen, op het totaal aantal voor het gezin van toepassing zijnde taken. Het gaat hierbij niet alleen om taken die de man alleen doet, maar ook om de taken die hij afwisselend dan wel samen met andere gezinsleden doet. voor 
de analyse van het verloop in de participatie aan het huishouden vallen twee patiënten af: én in de revalidatie(weduwnaar) en een in de kontrolegroep (ongehuwd). Een analyse in het verloop in de participatie an het huishouden late zien dat het hier gaat om een betrekkelijk konstant gegeven (tabel 6.6).

Tabel 6.6: Het verloop van de proportie huishoudelijke taken van de man op het totaal aantal taken in revalidatie- en kontrolegroep.

\begin{tabular}{lrcccc}
\hline maanden na MI: & 3 & 6 & 12 & 24 \\
\hline revalidatie & $\bar{x}$ & $\frac{.34}{(.26)}$ & $\frac{.39}{(.27)}$ & $\frac{.43}{(.25)}$ & $\frac{.41}{(.25)}$ \\
& $\min -\max$. & $0-.90$ & $0-1.0$ & $0-.91$ & $0-.82$ \\
kontrole & $\bar{x}$ & $\frac{.37}{(.20)}$ & $\frac{.40}{(.22)}$ & $\frac{.41}{(.23)}$ & $\frac{.42}{(.21)}$ \\
& $\operatorname{s.d.}$ & $0-.77$ & $.09-.77$ & $.09-.80$ & $.27-.77$ \\
\hline
\end{tabular}

Fr is weliswaar een stijqende tendens waar te nemen, maar slechts énmal is sprake van een signifikante toename en wel in de revalidatiegroep van 3 naar 12 maanden na infarct (wilcoxon, $\mathbb{T}=29, \mathrm{p}<.05$ ). Verschillen in toename tussen revalidatie- en kontrolegroep zijn statistisch niet aantoonbaar.

De konklusie is dat revalidatie geen invloed heeft op de participatie van de man aan het huishouden. Wel is sprake van een lichte stijgende tendens, vooral in de gerevalideerde groep. Wij beschikken niet over gegevens over de situatie van voor het infarct op dit punt. Het is dus moeilijk een uitspraak te doen over het eventuele niveauverschil tussen de situatie van vór en na het infarct.

In de literatuur is gesuggereerd dat het niveau na infarct in het algemeen lager ligt dan ervoor. In absolute zin lijkt echter een participatie waarbij de man aan drie tot vijf taken deelneemt zeker niet laag te noemen. In een Amerikaans onderzoek in gezinnen met gezonde leden, waarin dezelfde mat voor participatie werd gebruik, is de proportile 
taken van de man .21 (0-.75) (Berk \& Berk, 1978). We nemen daarom aan dat op zijn minst sprake is van een normal participatie-niveau van de man en wellicht zelfs van een verhoogd participatie-niveau.

Vrije tijd

Voor de vastlegging van de aktiviteiten in de vrije tija is gebruik gemaakt van de lijst van wippler (1968). Bij 23 aktiviteiten kan worden aangegeven of men die aktiviteiten nooit, af en toe, of geregeld onderneemt (scores respektievelijk 0, 1, 2). In dit onderzoek waren we vooral geinteresseerd in die aspekten, die men als aktieve vrijetijdsbesteding kan aanmerken. Mede op geleide van Wippler is hier gekozen voor een analyse op de volgende vormen van vrijetijasbesteding: vitad-expansieve vrijetijdsbesteding: participatie aan verenigingen, zwemmen, dansen, latent-spannende vrijetijdsbesteding: bezoeken van sportwedstrijden, vissen, cafe-bezoek, kaarten; rekreatieve vrijetijdsbesteding: wandelen, tochtjes maken met flets of auto; en praktisch-nuttige vrijetijdsbesteding: het beoefenen van een hobby en het opknappen van lets aan het huis.

In totaal omvatten deze vier kategorieën 12 items, zodat de maximum-score $24 \mathrm{kan}$ bedragen. De minimum-score $1 \mathrm{~s}$ uiteraard gelijk aan 0 .

Het verloop van de scores voor aktieve vrijetijdsbesteding geven een wederom redelijk konstant beeld (tabel 6.7).

Tabe1 6.7: Het verloop van de scores voor aktleve vrijetijdsbesteding in revalidatie- en kontrolegroep.

maanden na $\mathrm{MI}$ :

3

6

12

revalidatie

$\begin{array}{rcccc}\bar{x} & \frac{8.7}{3 . a} \cdot(3.6) & \frac{9.0}{(3.4)} & \frac{8.8}{(3.0)} & \frac{8.9}{(3.1)} \\ \min .-\max . & 2-14 & 3-14 & 2-14 & 2-14\end{array}$

kontrole

\begin{tabular}{|c|c|c|c|c|}
\hline $\bar{x}$ & 9.2 & 9.8 & 9.6 & 9.5 \\
\hline & (3.6 & $(3.0)$ & $(3.1)$ & 12 \\
\hline$n \cdot-\max$ & 3.16 & $4-16$ & $3-15$ & $3-15$ \\
\hline
\end{tabular}


Als al sprake is van verandering dan gebeurt die in de vorm van een toename tussen drie en zes maanden, met name in de kontrolegroep. Geen der toenames of verschillen daarin tussen revalidatie- en kontrolegroep bereiken een signifikant niveau. Overigens moet wederom gekonstateerd worden dat de kontrolegroep systematisch boven het niveau van de revalidatiegroep ligt.

ook in dit geval kon niet worden beschikt over gegevens van de aktieve vrijetijasbesteding vór het infarct. Raadpleging van de cijfers van wippler (1968) helpt ons in dit geval niet veel verder, omdat zijn rechte telinger voor mannen én vrouwen zijn gegeven. Wanneer afgezien wordt van het onderscheid naar geslacht, dan verkrijgt men een gemiddelde score van 7 voor de items die zowel door wipplex als hier gebruikt zijn. Nu blijken latent-spannende en praktisch-nuttige vrijetijdsbesteding vooral door mannen beoefend te worden zodat men moet aannemen dat de scores voor mannen hoger dan gemidaeld 7 zullen liggen. In elk geval krijgt men uit de cijfers van het huidige onderzoek niet de indruk van een drastisch verlaagd niveau van aktieve vrijetijdsbesteding.

Men moet echter oog houden voor het feit dat de aktiviteitsgraad wél drastisch gedaala is, zodat men genoodzaakt is te veronderstellen dat het niveau van de aktieve vrijetijasbesteding na infarct lager is dan ervoor, en, dat als deze aktiviteiten platsvinden, ze met minder fysieke inzet gedaan zullen worden.

De konklusie is dat revalidatie geen invloed heeft op de aktieve vrijetijdsbesteding. De aktieve besteding van de vrlje tija blijkt, met uitzondering van de periode gelegen tussen drie en zes maanden na infarct, een betrekkelijk konstant gegeven te zijn.

\section{De dagindeling}

Het interview dat gebruikt werd om de aktiviteitsgraad vast te stellen ging uit van de dagindeling van een doorsnee doordeweeksedag. De gegevens die dit interview opleverde konden ook gebruikt worden om de gemiddelde dagindeling vast te leggen. De dagindeling wordt meestal weergegeven in aard en duur van bepaalde aktiviteiten.

De dagelijkse aktiviteiten zijn hier ondergebracht in het teoretisch fraaie en praktisch simpele systeem van As (1978), waarin de aktiviteiten gerangschikt zijn naar de mate van 
vrijheid die men heeft bij het ondernemon ervan. Aktiviteiten, die weinig vrijheidsgraden kennen, struktureren de dag het sterkst. De kategorieën zijn achtereenvolgens:

1. noodzakelijke tijd: is de tijd die nodig is om basale fysiologische behoeften te bevredigen. Het slapen is het belangrijkste bepalende element in deze kategorie, waarin verder vallen: eten en persoonlijke verzorging;

2. de gekontrakteerde tijd: is de tijd die men besteedt volgens in een kontrakt neergelegde overeenkomst. In het algemeen komt dit dus neer op het aantal uren betald werk. Reizen van en naar het werk worden ook onder deze kategorie gerangschikt. In tegenstelling tot As hebben wij ook de tijd die besteed werd aan de maltijden tijdens het werk hier ondergebracht, omdat plaats en duur van deze maltijden in het algemeen worden opgelegd door de werksituatie;

3. de zelf opgelegde tijd: wat betreft aktiviteiten waarbij sprake is van een commitment van de zijde van de actor. Alle huishoudelijke taken, maar ook hobbies vallen hieronder. Wanneer deze aktiviteiten plaatsvinden in het kader van een uitgesproken overeenkomst met anderen en waarbij sprake is van geldelijke vergoeding, behoren ze onder de tweede kategorie te worden ondergebracht;

4. de vrije tijd: is de tijd die naar believen kan worden ingevuld.

In tabel 6.8 is het vcrloop van de dagindeling in revalidatie- en kontrolegroep weergegeven. De gegevens over de situatie op twalf maanden na infarct zijn in deze tabel bulten beschouwing gebleven, omdat deze overeenkomen met die van zes maanden.

Het verloop van de dagindeling verschilt niet veel tussen revalidatie- en kontrolegroep, met uitzondering van de gemiddelde gekontrakteerde tijd. Deze neemt in de kontrolegroep sneller toe en bereikt een hoger niveau.

Dit heeft uiteraard te maken met het felt dat in de kontrolegroep sneller, meer, en meer geheel het werk hervat wordt. voor beide groepen geldt dat de dagindeling voór het infarct bepaald wordt door de gekontrakteerde en de noodzakelijke tijd: deze nemen driekwart var het etmaal in beslag. Na het infarct memen de vrije en de noodzakelijke tijd sterk toe. $\mathrm{Na}$ een daling van drie tot twalf maanden na infarct blijven 
zij konstant en bepalen 24 maanden na infarct voor circa 70 : de dag.

Tabe1 6.8: Het verloop van de dagindeling in revalidatieen kontrolegroep (in uren gemiddeld).

\begin{tabular}{lcccc}
\hline maanden na MI: & 0 & 3 & 6 & 24 \\
\hline $\begin{array}{l}\text { noodzakelijke tijd } \\
\text { revalidatie } \\
\text { kontrole }\end{array}$ & 7.6 & 10.5 & 9.6 & 8.9 \\
$\begin{array}{l}\text { gekontrakteerde tijd } \\
\text { revalidatie }\end{array}$ & 7.6 & 10.2 & 9.8 & 8.9 \\
kontrole & 10.8 & 0.2 & 1.3 & 4.2 \\
$\begin{array}{l}\text { zelf opgelegde tijd } \\
\text { revalidatie }\end{array}$ & 11.3 & 0.7 & 3.1 & 5.8 \\
kontrole & 0.9 & 2.7 & 3.2 & 2.3 \\
$\begin{array}{l}\text { vrije tijd } \\
\text { revalidatie }\end{array}$ & 1.1 & 2.3 & 2.5 & 1.8 \\
kontrole & 5.0 & 10.6 & 10.0 & 8.8 \\
\hline
\end{tabular}

Deze situatie met veel slapen en vrije tijd leidt tot een laag niveau van aktiviteiten en tot een betrekkelijke ongestruktureerdheid van het dagelijks leven.

Wanneer de cijfers van Knulst (1977) betreffende de tijdsbesteding in een steekproef van werkende mannen in dezelfde kategorieën als hier gebruikt worden ondergebracht, brengt een vergelijking met de dagindeling van vorr het infarct in revalidatie- en kontrolegroep met de landelijke cijfers een paar interessante verschilien aan het licht (tabel 6.9).

Tabel 6.9: De dagindeling voor het infarct in revalidatieen kontrolegroep vergeleken met landelijke cijfers (Knulst, 1977) (in uren gemiddeld)

\begin{tabular}{lccc} 
& revalidatie & kontrole & landelijk \\
\cline { 2 - 4 } noodzakelijke tijd & 7.6 & 7.6 & 9.7 \\
gekontrakteerde tijd & 10.8 & 11.3 & 9.0 \\
zelf opgelegde tijd & 0.9 & 1.1 & 0.6 \\
vrije tijd & 4.7 & 4.0 & 4.7 \\
\hline
\end{tabular}


Het gemiddeld aantal uren vrije tijd is vrijwel gelijk aan het landelijke cijfer. De gemiddelde tija die besteed wordt aan bepaalde commitments ligt zo'n anderhalf maal hoger. Hierbij moet wel in overweging genomen worden dat de kodering van deze kategorie het meest problematisch is. Met betrekking tot de twee meest betrouwbaar vast te stellen kategorieën, namelijk de noodzakelijke en de gekontrakteerde tijd, valt de betrekkelijk lange duur van de gekontrakteerde tijd op: deze ligt voor ons onderzoek gemiddeld zo" $\mathrm{n}$ twee uur hoger dan het landelijke cljfer. Gezien de verdeling van de uren over de vrije en de zelf opgelegde tijd, gaat dit vooral ten koste van de tijd voor slapen en persoonlijke verzorging. Bij de vergelijking van onze cijfers met de landelijke moet rekening worden gehouden met het feit dat de onderzoeksgroep gemiddeld ouder is dan de landelijke. Uit de gegevens van knulst blijken mannen boven de 50 meer tijd uit te trekken voor slapen plus persoonlijke verzorging en minder uren te besteden aan gekontrakteerde tijd, dan de mannen beneden die leeftijd. Dit gegeven betekent dat het verschil tussen de landelijke en onze cijfers nog groter is dan uit de tabel blijkt. Hier staat tegenover dat de gekontrakteerde tijd in ons onderzoek een half a een uur te hoog ligt door het meetellen van de lunchpauze Niettemin lijkt men in de dagindeling van de -potentiëlehartinfarctpatienten het beeld van het zogenaamde A-type, voor wie werk een zeer voorname plaats Inneemt, te kunnen ontwaren.

Al met al is van een invloed van de revalidatie op de dagindeling weinig te bespeuren geweest. Het enige vermeldenswaardige op dit punt is de relatief snellere toename van de gekontrakteerde tijd in de kontrolegroep, die, zoals we gezien hebben, moet worden teruggevoerd op het werkhervattingspatroon in deze groep.

In de dagindeling van de -potentiële- hartinfarctpatiënten blijkt in vergelijking met landelijke cljfers van werkende mannen een ruimere plaats voor werk en minder tlja voor de bevrediging van noodzakelijke behoeften te bestaan.

\subsection{Subjektief herstel}

De in dit onderzoek gebruikte schalen als de hiervoor gerapporteerde subjektieve belasting en gepercipleerde inspan- 
ningstolerantie proberen op objektieve wijze de beleving van de aandoening door de patiënt vast te leggen. Naast deze indirekte en kwantitatieve benadering zijn echter ook direkte vragen betreffende de beleving aan de patiënt gesteld, waarvan we er hier twee zullen behandelen. op elk meettijdstip is de patiënt gevraagd of hij optimistisch dan wel pessimistisch was over zijn toekomstige gezondheid. Het antwoord kan worden gegeven op een vierpuntsschaal van optimistisch naar pessimistisch. Tabel. 6.10 geeft het verloop in de proportie optimistische plus redelijk optimistische patiënten in revalidatie- en kontrolegroep.

Tabe 1 6.1C: Het verloop in de proportie patiënten die optimistisch zijn over hun toekomstige gezondheid in revalidatie- en kontrolegroep.

\begin{tabular}{lcccc}
\hline maanden na MI: & 3 & 6 & 12 & 24 \\
\hline revalidatie & .58 & .71 & .63 & .50 \\
kontrole & .78 & .78 & .67 & .74 \\
\hline
\end{tabular}

Patiënten uit de kontrolegroep zijn en blijven wat betreft hun toekomstige gezondheid iets optimistischer dan die uit de revalidatiegroep. In de laatstgenoemde groep treedt tussen drie en zes maanden een geringe stijging van het aantal optimisten op, daarna is sprake van een daling. Er zijn echter geen signifikante verschillen tussen de twee groepen, noch wat betreft de situatie op de vier metingen, noch ten aanzien van de veranderingen daartussen.

Op elk meettijdstip is de patiënt eveneens gevraagd of hij wist waar hij in lichamelijk opzicht aan toe was. Als toelichting bij deze vraag, die met ja of nee beantwoord kon worden, werd de patiënt uitgenodigd bij zichzelf na te gaan of hij wist hoever hij wat lichamelijke inspanning betreft kon gaan. Een positief antwoord op deze vraag kan natuurlijk ketrekking hebben op zowel een slechte als een goede lichamelijke toestand. Waar het echter om gaat is, dat een positief antwoord duidt op een inzicht in, casu 
quo acceptatie van, de beperkingen die door het hartinfarct zijn ontstaan. Tabel 6.11 geeft het verloop van de proportie patiënten, die op deze vraag een positief antwoord gaven. Hierbij moet worden opgemerkt dat wanneer de vraag met een wraagteken werd beantwoord, dit als een negatief antwoord werd beschouwd.

Tabel 6.11: Het verloop in de proportie patienten die weten waar ze in lichamelijk opzicht aan toe zijn in revalidatie- en kontrolegroep.

\begin{tabular}{lccccc}
\hline maanden na MI: & 3 & 6 & 12 & 24 & $\begin{array}{c}\text { trend-toets } \\
\text { (Eénz.) }\end{array}$ \\
revalidatie & .45 & .67 & .75 & .67 & $\mathrm{p}=.24$ \\
kontrole & .48 & .70 & .81 & .81 & $\mathrm{p}=.12$ \\
\hline
\end{tabular}

In beide groepen is, vanuit een gelijke startpositie, een stijgende tendens waarneembaar tot éen jaar na infarct. In de kontrolegroep vindt een konsolidatie plaats, terwijl in de revalidatiegroep een lichte daling optreedt. De stijgende tendens is dus duidelijker aanwezig in de kontrole- dan in de revalidatiegroep, zoals ook blijkt uit de resultaten van de trend-toets.

De bevindingen ten aanzien van het subjektleve herstel zijn in overeensteming met die over het objektieve herstel (met uitzondering van de kortdurende winst in 1 lchamelijk prestatievermogen): revalidatie heeft geen aantoonbare invloed op het subjektieve herstel. Bovendien moet wederon gekonstateerd worden dat de kontrolegroep zich als gunstiger manifesteert als de revalidatiegroep, en wel systematisch op alle meettijdstippen.

\subsection{Revalidatie en de partner}

Bij de beschrijving van het revalidatieprogramma in hoofdstuk 2.3 is al vermeld dat de partners van de gerevalideerde patiënten niet systematisch, maar wel zoveel mogelijk, bij het programma betrokken werden. Het zou dus te ver gaan uitgesproken verwachtingen over de invloed van het revalidatie- 
programma op de partner te formuleren.

Dit neemt niet weg dat de hoop bestond dat de vrouwen van de gerevalideerde patiënten door de revalidatie een minder overbezorgde houding tegenover hun man zouden gaan aannemen. Dit probleem zal hier op twee manieren worden benaderd. op de eerste plaats is de vrouwen op elk meettijdstip gevraagd op de PET-schaal aan te geven tot welke aktiviteiten zij hun man in staat achtten. Aangezien de man dezelfde schal heeft ingevuld is een direkte vergelijking mogelijk. Ten tweede is aan de vrouwen gevraagd of zij $z i c h$ afkeurend dan wel juist aanmoedigend ten aanzien van hun man opstelden. Diezelfde vraag is ook aan de mannen voorgelegd, zodat ook hier een direkte vergelijking mogelijk is. Voor de analyse van deze gegevens kon in de revalidatiegroep beschikt worden over 21 echtparen ( 1 weduwnaar, 2 gevallen met te weinig gegevens), terwijl in de kontrolegroep 25 echtparen beschikbaar waren $(1$ ongehuwde, 1 geval met te weinig gegevens).

Een analyse van het verloop van de PET-scores (tabel 6.12) laat zien dat in beide groepen de vrouwen hun mannen tot minder in staat achten dan de mannen zelf. Het verschil is echter alleen signifikant drie maanden na infarct (getoetst met wilcoxon: revalidatie: $T=3, p<.01$; kontrole: $T=54.5, p<.02$ ).

Tabel 6.12: Het verloop van de PET-scores bij vrouwen en hun mannen in revalidatie- en kontrolegroep.

mäanden na MI:

3

6

12

revalidatie:

PET

$\mathrm{PLT}$

overeenstemming ( $(\hat{\mathrm{K}})$

\begin{tabular}{|c|c|c|c|c|}
\hline $\bar{x}$ & 2.7 & 3.7 & 3.3 & 3.4 \\
\hline s.d. & $(\overline{1.4})$ & $(\overline{1.3})$ & $(\overline{1.5})$ & $(1.8)$ \\
\hline$\vec{x}$ & 3.5 & 4.0 & 3.8 & 4.0 \\
\hline s.d. & $(\overline{1.6})$ & $(\overline{1.7})$ & $(\overline{1.6})$ & $(\overline{1.8})$ \\
\hline & .13 & .37 & 23 & .19 \\
\hline
\end{tabular}

kontrole:

PET o

PET $\sigma^{\circ}$

overeenstemming ( $\hat{K}$ )

\begin{tabular}{|c|c|c|c|c|}
\hline $\bar{x}$ & 3.0 & 3.8 & 3.7 & 4.0 \\
\hline . $d$. & $(\mathbb{1 . 5})$ & $(1.7)$ & $(1.6)$ & $(\overline{1.5})$ \\
\hline $\bar{x}$ & 3.7 & 4.1 & 4.2 & 4.1 \\
\hline d. & $(1.5)$ & $(\overline{1.8})$ & $(1.6)$ & $(1.5)$ \\
\hline & .07 & .41 & .25 & .29 \\
\hline
\end{tabular}


$\mathrm{Na}$ de aanvankelijke onderschatting van de man, vindt tussen drie en zes maanden een aanpassing van het oordeel van de vrouw aan dat van de man plaats: in zowel revalidatie- als kontrolegroep stijgt de $\mathrm{PET}$-score van de vrouwen signifikant (Wilcoxon: revalidatie: $T=0, p<.01$; kontrole: $T=18$, $p<.05)$. De overeenstemming tussen de echtelieden is zes maanden na infarct het grootst, daarna wordt deze kleiner, vooral in de revalidatiegroep, omdat de vrouwen in die groep weer een tendens tot onderschatting te zien geven. Het moge duidelijk zijn dat het verloop van de PET-scores van de vrouwen in beide groepen globaal hetzelfde beeld te zien geeft, zodat gekonkludeerd moet worden dat de revalidatie geen invloed heeft op de door de vrouw gepercipieerde inspanningstolerantie van de man.

Aan de vrouwen is ook gevraagd of $z i j$ hun afkeuring ten aanzien van bepaalde aktiviteiten of gedrag lieten blijken, dan wel juist hun man aanmoedigden andere aktiviteiten te ondernemen. Wanneer we nu eerst bezien hoe het verloop is in het aantal vrouwen dat zegt überhaupt lets te laten blijken, dan blijken de meesten dit in de beginfase te doen. In de revalidatiegroep is echter sprake van een dalende tendens van de proportie vrouwen die lets laten merken, terwijl in de kontrolegroep aanvankelijk wel een daling optreedt, maar twee jaar na infarct een zekere opleving op dit punt te konstateren valt (tabel 6.13).

Tabe1 6.13: Het verloop in de proportie vrouwen die zeggen iets te laten blijken over gewenst of ongewenst gedrag van hun man.

\begin{tabular}{lccccc}
\hline maanden na MI: & 3 & 6 & 12 & 24 & $\begin{array}{c}\text { trend-toets } \\
\text { (eenz.) }\end{array}$ \\
\cline { 1 - 3 } & .90 & .81 & .71 & .62 & $\mathrm{p}=.08$ \\
kontrole & .80 & .60 & .60 & .78 & $\mathrm{p}=.43$ \\
\hline
\end{tabular}

Een analyse van het verloop in de aard van de door de vrow verzonden informatie laat zien dat het aantal aanmoedigende vrouwen in de revalidatiegroep betrekkelijk konstant is, terwijl het aantal vrouwen dat gedrag van hun mannen -al dan niet in kombinatie met een aanmoediging- afkeurt, daalt. 
In de kontrolegroep is juist het aantal vrouwen in de laatst genoemde kategorie konstant, terwijl het aantal bemoedigende vrouwen een tendens tot daling vertoont. De overeenstemming tussen de echtelieden, waarbij vanzelfsprekend ook rekening is gehouden met de situatie waarin geen sprake is van een verzonden of ontvangen boodschap, is in het algemeen niet hoog te noemen, vooral niet voor de eerste twee metingen in de revalidatiegroep (bijlage 11). Zonder dat sprake is van signifikante verschillen tussen beide groepen, lijken de resultaten van de analyse zich ten gunste van de vrouwen van de gerevalideerde patiënten af te tekenen. Men zou kunnen konkluderen dat de revalidatie de vrouwen in hun aanmoedigende houding sterkt, terwijl de afkeurende benadering geleidelijk vermindert.

Zoals gezegd is de overeenstemming tussen man en vrouw betreffende aanmoedigende of afkeurende uitingen van de vrouw riet erg hoog. Het blijkt dat in beide groepen een systematisch verschil tussen de echtelieden bestaat: de mannen percipiëren meer afkeuring dan de vrouwen zeggen te laten merken, terwij1 omgekeerd de vrouwen meer aanmoedigingen zeggen te geven dan de mannen zeggen te ontvangen. Met andere woorden, de mannen plaatsen de bemoeienis van hun vrouw in een negatief kader, terwijl de vrouwen zichzelf in een meer positieve rol zien.

De vraag die nu naar voren komt is wat de invloed van de opvattingen en uitingen van de vrouw is op het herstel van de man. Het blijkt dat wat de vrouw meent of laat merken geen direkte relatie vertoont met de in dit onderzoek gehanteerde herstelcriteria. Er is wél een relatie tussen de pexceptie van de man betreffende de bemoeienis van zijn vrouw en de uiteinde1ijke hervatting: mannen die 24 maanden na infarct het werk hervat hebben, percipiëren arie en zes maanden na infarct signifikant minder bemoeienis van hun vrouw dan de mannen die het werk niet hervatten (tabe1 6.14). Dar het gekonstateerde verschijnsel zich in revalidatieen kontrolegroep in wrijwel dezelfde mate manifesteert, is de analyse voor beide groepen tesamen uitgevoerd. Van belang is op te merken dat de perceptie van de nietbemoeienis betrekkelijk onafhankelijk is van hetgeen de vrouw zegt: van de acht mannen die op drie maanden zeggen geen bemoeienis te percipiëren is dat voor vijf van hen ten onrechte, van de 13 op zes maancen na infarct is dat vor 8 ten onrechte. 
I"abe1 6.14: Gepercipieerde bemoeienis van de vrouw en werkhervatting (revalidatie- en kontrolegroep).

maanden na $\mathrm{MI}$ :

man percipieert bemoeienis: we1

niet
3 maanden

hervat:

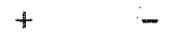

17

21

38

\begin{tabular}{rrr}
8 & 0 & 8 \\
\hline 25 & 21 & 46
\end{tabular}

$p=.004$
6 maanden

hervat:

Fisher"s ex prob.:

$p=.053$

De overeenstemming tussen man en vrouw is voor de hervatters en niet-hervatters ongeveer gelijk op drie maanden: van de 25 uiteindelijke hervatters stemmer er 9, van de 21 niethervatters zeven van de 21 overeen met hun vrouw zes maanden na infarct is de overeenstemming gedaald bij de hervatters (6 van de 25) en gestegen bij de niet-hervatters (9 van de 21). Men moet dus konkluderen dat die mannen die het werk zullen hervatten al in een vroeg stadium van het herstel de eventuele bemoeienis van hun vroww in hun voordeel perclpieren. Er blijkt echter een verband te bestaan tussen de perceptie van de man en de duur van het huwelijk: mannen die de signalen van hun vrouw in hun voordeel percipieren zijn gemiddela genomen korter gehuwd dan de mannen die dat niet doen (18 versus 28 jaar). De duur van het huwelijk houdt echter weer verband met de leeftijd, die op zijn beurt weer met de hervatting samenhangt.

Het gevonden verband tussen perceptie en hervatting moet dus worden gekontroleerd op de invloed van leeftija. Voor de situatie drie maanden na infarct blijkt het verband tussen perceptie en hervatting $(r=-42)$ stand te llouden wanneer de leeftijd konstant wordt gehouden: leeftija en hervatting hangen sterk negatief samen $(r=-.58)$, leeftija en perceptle zwak positief $(r=.29)$, de partiele korrelatie perceptiehervatting met leeftija konstant,bereikt dan de warde van $-.34(p<.05)$. Voor de situatie zes maanden na infarct houdt het verband echter geen stand. Het heeft er dus alle schijn van dat de perceptie door de man van de bemoeienis van zijn 
vrouw arie maanden na infarct van voorspellende betekenis is voor de uiteindelijke hervatting.

\subsection{Samenvattende analyse}

De mogeljkheden voor een multivariate analyse zijn gegeven het aantal herstelvariabelen en de grootte van de onderzoeksgroep uiterst beperkt. Daarom zal hier gepoogd worden in een typologische aanpak tot een samenvattende analyse te komen. Hoewel het voox de hand ligt te werken met drie samengestelde maten voor fysiek, psychisch en sociaal herstel afzonderlijk, is hier in verband met de beschikbare aantallen gekozen voor én mat voor fysiek en psychisch herstel enerzijds en een voor sociaal herstel anderzijds.

\section{Fysiek en psychisch herstel}

De maat voor fysiek en psychisch herstel is opgebouwd uit arie elementen: de maximale imspanningstolerantie, de aktiviteitsgraad en de subjektieve belasting. De keuze van deze faktoren berust op hun konceptuele verwantschap, respektievelijk: het vermogen tot inspanning, de feitelijke mate van aktiviteit en de ervaren belasting bij dagelijkse aktiviteiten. Bij de konstruktie van de mat voor fysiek en psychisch herstel is gebruik gemaakt van de volgende cut-off-punten:

a. Het maximale inspanningsvermogen (in watt) is omgerekend als percentage van de op basis van leeftijd, lengte en gewicht te verwachten prestatie. Dit percentage wordt de Eysiologische validiteit genoend (weeda et al., 1975). Een validiteit van minder dan 95\%, dat wil zeggen een geleverde prestatie die meer dan 1 standaardmeetfout $(=10$ Watt) beneden de te verwachten prestatie ligt, wordt hier als negatief beoordeeld. Validiteiten van $95 \%$ en meer worden als positief beoordeeld.

b. Voor de aktiviteitsgraad is geen extern kriterium voorhanden. Als referentiepunt is hier de aktiviteitsgraad van vóor het infarct gebruikt. De aktiviteitsgraad op de vier metingen na het infarct is uitgedrukt als percentage van die van vớr het infarct. De mediane wararde van dit percentage bedraagt $75 \%$. Een aktiviteitsgraad die meer dan 75\% bedraagt van die van vór infarct wordt hier als positief beoordeeld, die van $75 \%$ en minder als negatief. 
c. Een subjektieve belasting-score (SB) die meer dan én standaardmeetfout $(=3)$ boven de gemiddelde score van gezonde mannen $(=12)$ ligt, dus een score van hoger dan 15, wordt als negatief beoordeeld. Een score van $15 \mathrm{en}$ minder wordt bijgevolg als positief beoordeeld.

De drie faktoren van elk twee mogelijke waarden $(+,-)$, leveren dan met elkaar acht mogelijke uitkomsten op. Gezien de beschikbare aantallen is de volgende vereenvoudiging aangebracht: patiënten die op alle drie herstelindikatoren positief scoren komen in de gunstigste katecorie, daarna zij die op twee positief, dan zij die op slechts eén positief en tenslotte de patiënten die op alie drie negatief scoren.

Alvorens in te gaan op het verloop in het fysiek/psychisch herstel in revalidatie- en kontrolegroep, zal eerst nog worden stil gestaan bij de onderlinge relatie in de totale groep, tussen de gedichotomiseerde herstelindikatoren. Het blijkt dat van drie naar twaalf maanden na infarct sprake is van een in sterkte toenemende relatie tussen de drie indikatoren. Twaalf maanden na infarct vertonen ze alle drie een signifikante, positieve samenhang (tabel 6.15).

Tabel 6.15: De onderlinge samenhang van de drie herstelindikatoren van fysiek en psychisch herstel ( $n=$ $51 ; \varphi$-koëfficiënten).

\begin{tabular}{lccll}
\hline maanden na MI: & 3 & 6 & 12 & 24 \\
\hline valid. - akt.gr. & -.14 & .06 & $\left..33^{*}\right)$ & .24 \\
valid: - sB & .03 & .15 & $\left..30^{*}\right)$ & $\left..30^{*}\right)$ \\
SB - akt.gr. & .12 & .20 & $\left..43^{*}\right)$ & .13 \\
\hline
\end{tabular}

*) p<.05

Dit betekent dat in het eerste jaax na infarct een gunstige validiteit, een hoog aktiviteitenniveau en een lage subjektieve belasting (SB) op den duur samengaan.

De analyse van het verloop in het fysiek/psychisch herstel. (tabel 6.16), laat zien dat de kontrolegroep, zoals op basis van het voorafgaande verwacht kon worden, een lets betere uitgangspositie heeft. 
Tabel 6.16: Het verloop in het fysiek/psychisch herstel in revalidatie- en kontrolegroep.

\begin{tabular}{rrrrrrrrr}
\hline & \multicolumn{3}{c}{ revalidatie } & \multicolumn{3}{c}{ kontrole } \\
maanden na MI: & 3 & 6 & 12 & 24 & 3 & 6 & 12 & 24 \\
\hline $\begin{array}{c}\text { aantal indikato- } \\
\text { ren positief: }\end{array}:$ & 1 & 5 & 5 & 5 & 2 & 6 & 7 & 7 \\
$2:$ & 8 & 10 & 9 & 6 & 12 & 8 & 7 & 11 \\
$1:$ & 9 & 8 & 5 & 8 & 9 & 9 & 8 & 7 \\
$0:$ & 6 & 1 & 5 & 5 & 4 & 4 & 5 & 2 \\
& $\overline{24}$ & $\overline{24}$ & $\overline{24}$ & $\overline{24}$ & $\overline{27}$ & $\overline{27}$ & $\overline{27}$ & $\overline{27}$ \\
\hline
\end{tabular}

Indikatoren: validiteit $>958=+$

akt.graad $>75$ van akt.graad vóor infarct $=+$ $\mathrm{SB}$ $\$ 15=+$

Na de revalidatie, zes maanden na infarct, blijkt zich een positieve verandering te hebben voorgedaan in de revalidatiegroep. Deze verandering komt bijna geheel voort uit de gestegen inspanningstolerantie. Omdat in de kontrolegroep de, eveneens positieve, verandering kleiner is, is het verschil in vcrandering tussen beide groepen over de periode drie tot zes signifikant ten gurste van de revaliatiegroep $\left(X_{L}^{2}=9.46, d f=2, p<.01\right)$. Na zes maanden tekent zich echter in de revalidatiegroep een ongunstige ontwikkeling af, terwijl tussen een en twee jaar na infarct in de kontrolegroep juist een positieve ontwikkeling valt te konstateren. Het verschil in verandering is in die periode signifikant ten gunste van de kontrolegroep $\left(X_{L}^{2}=7.97, d f=2, p<.05\right)$. Deze ontwikkeling is vooral toe te schrijven aan het feit dat de aktiviteitsgraad in de kontrolegroep stijgt, terwijl die in de revalidatiegroep maar weinig verandert. Bovendien speelt de revalidatiegroep de daling van het inspanningsvermogen parten. De konklusies van de samenvattende analyse bevestigen in grote lijnen die ten aanzien van de verschillende herstelindikatoren, zij het dat hier de verschillen in verandering tussen twee groepen duidelijker naar voren komen: de revalidatiegroep boekt, vooral op 
basis van het gestegen inspanningsvermogen, een tijdelijke winst, die niet behouden blijft omat die winst blijkbaar onvoldoende wordt omgezet in winst op de andere twee herstelindikatoren. In de kontrolegroep is sprake van een fysiek/psychisch herstel in twee fasen: tussen drie en zes maanden is er een positieve ontwikkeling, terwijl het herstel tussen één en twee jaar na infarct doorzet.

\section{Sociaal herstel}

voor de konstruktie van de maat voor sociaal herstel is in eerste instantie uitgegaan van indikatoren op de leefgebieden werk, gezin en vrije tijd.

a. Wat betreft werk is uitgegaan van het simpele feit van werkhervatting. Een positieve score wordt toegekend ain hervatting, een negatieve aan niet-hervatting.

b. De participatie in huishoudelijke taken is hier benut als indikator voor aktiviteiten in het gezin. Als grens is de mediaan van de proportie taken door de man op het total aantal taken -over alle metingen-genomen $(=.40)$, mannen die minder dan .40 scoren, worden beschouwd als niet aktief in het huishouden, zij die .40 en hoger scoren, als aktief.

c. Voor de vrijetijdsbesteding is uitgegaan van de score op de aktieve vrijetijasbesteding. Als grens is ook hiex de mediane score over alle metingen genomen, namelijk 9. Mannen die minder dan 9 scoren worden beschouwd als niet aktief in hun vrije tijd, een score van 9 en hoger wordt beschouwd als aktieve vrijetijdsbesteding.

Wanneer allereerst de onderlinge relaties van de gedichotomiseerde indikatoren worden bezien, valt op dat er weinig onderling verband bestaat (tabel 6.17)

Tabel 6.17: De onderlinge samenhang tussen de drie herste1indikatoren van sociaal herstel $(n=51, \varphi$-koëfciënten).

\begin{tabular}{|c|c|c|c|c|c|}
\hline maanden na & MI : & 3 & 6 & 12 & 24 \\
\hline hervat & - part huish. & .15 & -.10 & -.07 & $\left.-.35^{*}\right)$ \\
\hline hervat & - vrije tijd & .15 & .08 & .26 & .07 \\
\hline part.huish. & - vrije tija & .06 & .10 & .06 & -.01 \\
\hline
\end{tabular}

*) $\mathrm{p}<.05$ 
De enige signiflkante relatie, namelijk de negatieve tussen hervatting en participatie huishouden op 24 maanden, is echter wel een belangrijke. Naast de triviale konstatering dat degenen die het werk hebben hervat minder in het huishouden participeren dan de niet-hervatters betekent dit, wanneer we bovendien letten op de positieve relatie tussen hervatting en aktieve vrijetijdsbesteding, dat voor de niet-hervatters niet de vrijetijasbesteding een kompensatie voor het niet werken is, mar de participatie in het huishouden.

Bilj de konstruktie van een mat voor sociaal herstel doet zich het probleem voor welk gewicht men an de drie indikatoren moet toekennen. In elk geval ligt het voor de hand aan werkhervatting een groter gewicht toe te kennen dan aan de andere indikatoren. Omdat, gezien de aantallen verdere opsplitsingen beperkt dienen te blijven, is gekozen voor de volgende procedure: in de groep hervatters wordt alleen onderscheid gemaakt tussen de hervatters die ook in hun vrije tijd aktief zijn en degenen die dat niet zijn. In de groep niet-hervat wordt onderscheid gemaakt in drie groepen:zij die zowel aktief in het huishouden participeren als een aktieve vrije tijdsbesteding hebben, zij die of in het huishouden of in de vrije tijd aktief zijn en tenslotte zij die noch in het huishouden noch in de vrije tijd aktief zijn.

Tabel 6.18: Het verloop in het sociale herstel in revalidatie- en kontrolegroep (abs. aantallen).

\begin{tabular}{|c|c|c|c|c|c|c|c|c|}
\hline \multirow[b]{2}{*}{ maanden na $\mathrm{MI}$ : } & \multicolumn{4}{|c|}{ revalidatie } & \multicolumn{4}{|c|}{ kontrole } \\
\hline & 3 & 6 & 12 & 24 & 3 & 6 & 12 & 24 \\
\hline \multicolumn{9}{|l|}{ hervat: } \\
\hline $\mathrm{VT}+$ & 1 & 2 & 8 & 5 & 2 & 9 & 9 & 8 \\
\hline $\mathrm{VT}-$ & 0 & 5 & 4 & 7 & 1 & 2 & 7 & 8 \\
\hline \multicolumn{9}{|l|}{ niet hervat: } \\
\hline VTt, hulsh.t & 5 & 6 & 3 & 5 & 6 & 2 & 2 & 3 \\
\hline VT of huish.+ & 10 & 5 & 6 & 4 & 13 & 9 & 5 & 6 \\
\hline \multirow[t]{2}{*}{ VT-, hudish. - } & 8 & 6 & 3 & 3 & 5 & 5 & 4 & 2 \\
\hline & $\overline{24}$ & $\overline{24}$ & $\overline{24}$ & $\overline{24}$ & $\overline{27}$ & $\overline{27}$ & $\overline{27}$ & $\overline{27}$ \\
\hline
\end{tabular}

Indikatoren (naast hervatting) : aktieve vrije tijdsbesteding: score $9=+$; participatie huishouden, proportie taken door de $\operatorname{man}>40=+$. 
De analyse van het verloop in het sociale herstel aan de hand van de gekozen kategorieën (tabel 6.18) laat wederom een iets gunstiger uitgangspositie voor de kontrolegroep zien. Naast de reeds bekende gunstiger ontwikkeling in de kontrolegroep voor hervatting, zien we zes maanden na infarct het verschijnsel dat de hervatters in de kontrolegroep in meerderheid ook een aktieve vrijetijdsbesteding hebben, terwijl in de revalidatiegroep de hervatters in meerderheid niet aktief zijn in de vrije tija. Men kan zich afvragen of wellicht de deelname aan de revalidatie, gekombineerd met hervatting, geen ruimte laat voor aktieve vrijetijdsbesteding. In de kategorie niet hervat zien we voor beide groepen een daling van de inaktiviteit. De konklusie, die uit de analyse getrokken kan worden, is dat geen duidelijke nieuwe gezichtspunten naar voren zijn gekomen en net als ten aanzien van de bevind.hngen over de afzonderlijke herstelindikatoren, gesteld kan worden dat geen duidelijke invloed van de revalidatie op het sociale herstel aantoonbaar is.

Samenhang tussen fysiek/psychisch en sociaal herstel Als laatste onderdeel van dit hoofdstuk zal worden ingegaan op de samenhang tussen fysiek/psychisch en soclaal herstel en de mate van voorspelbaarheid van de situatie betreffende deze herstelindikatoren uit de in de tijd voorafgaande toestand. Om in vogelvlucht hest herstel. in revalidatie- en kontrolegroep zichtbaar te maken is met behulp van Goodman en Kruskal's $\lambda$ nagegaan in hoeverne de fysiek/psychische en de sociale toestand, zoals die in het voorafgaande zijn beschreven, voorspellend zijn voor de situatie op het volgende tijdstip. De hler gebruikte associatiemaat heeft het voordeel van een zogenaande PRE-interpretatie (proportional reduction in error). Wanneer bij voorbeeld variabele $B$ uit A voorspeld kan worden met een $\lambda=.40$, dan lui.dt de interpretatie dat de fout die we zouden maken, indien we alleén ultgingen van de margïnale verdeling van $B$, met gemiddeld $40 \%$ is verminderd. Met andere woorden, hoe hoger de $\lambda$ tussen de variabelen $A$ en $B$, hoe informatiever de verdeling van $A$ is voor die van $B$ (Bishop et al. "1975). Voor de relatie tussen twee toestanden op hetzelfde tijdstip is de symmetrische variant van de 
$\lambda$ gebruikt. De interpretatie wordt vergemakkelijkt doordat alle in het geding zijnde relaties positief zijn. In figuur 7 is het verloop in de samenhang en voorspelbaarheid van belde herstelmaten weergegeven.

Figuur 7: Het verloop in de samenhang en voorspelbaarheid van fysiek/psychisch en sociaal herstel (Goodman en Kruskal"s $\lambda$ )

\section{Revalidatie}

Fysiek/psychisch herstel:

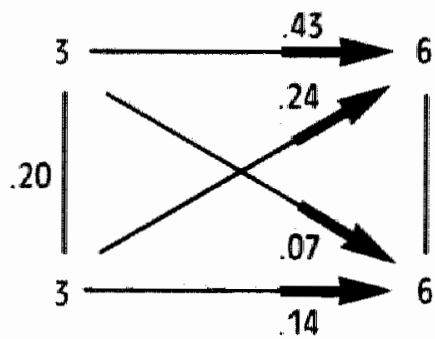

sociaal herstel:
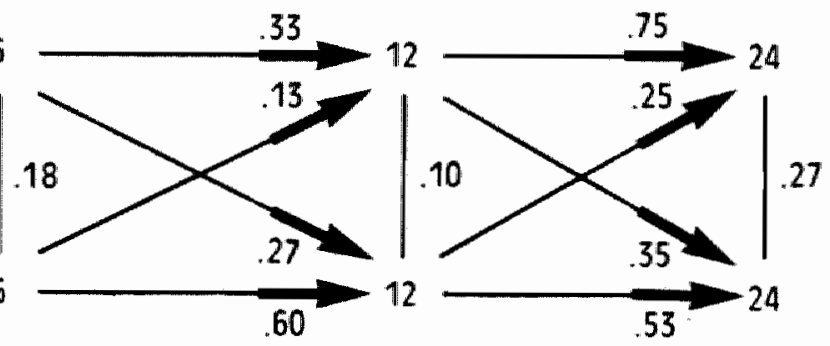

\section{Kontrole}

fysiek/psychisch herstel:
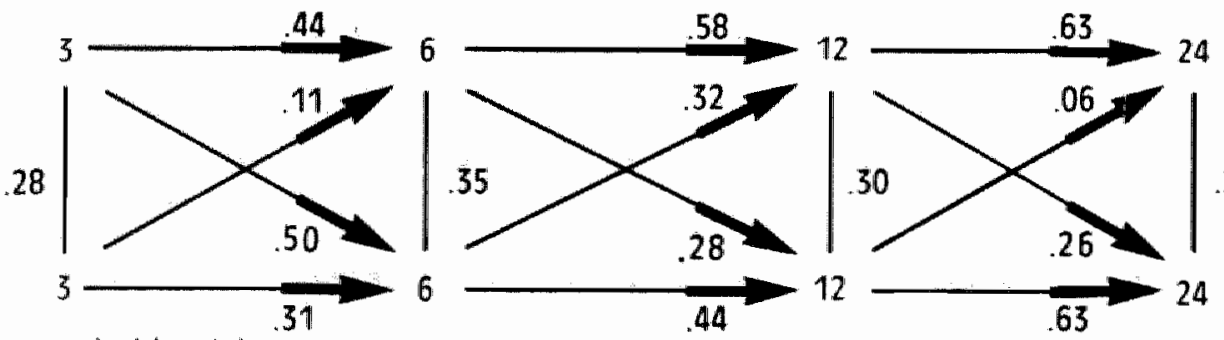

sociaal herstel:

In de kontrolegroep zien we dat de voorspelbaarheid van zowel fysiek/psychisch als sociaal herstel uit de voorafgaande toestand, toeneemt met de tijd. Dit duidt op een stabili- 
satie in het herstel, een verschijnsel dat in de revalidatiegroep minder duidelijk aanwezig is. Wat in de laatstgenoemde groep vooral opvalt is de zwakke relatie, die bestaat tussen de sociale toestand van arie en zes maanden na infarct. Een ander belangrijk verschil tussen beide groepen treedt eveneens op in de revalidatieperiode. In de kontrolegroep is de fysiek/psychische toestand van drie maanden van voorspellende betekenis voor de sociale toestand van zes maanden, een relatie die in de revalidatiegroep ten enenmale ontbreekt. Dit verschijnsel is terug te voeren op het feit dat in de kontrolegroep een, in vergelijking met de revalidatiegroep, meer systematische verbetering van de sociale toestand op zes maanden tot stand komt. Een interpretatie hiervan zou kunnen luiden dat de revalidatie een systematisch sociaal herstel in de weg staat.

6.8 Het Leidse onderzoek: samenvatting en diskussie

In dit hoofdstuk is op tal van manieren getracht na te gaan of revalidatie -een hopelijk positieve- invloed heeft op het herstel na hartinfarct. Wat betreft het fysieke herstel valt na revalidatie een trainingswinst te konstateren. Deze is echter na een half jaar weer verdwenen. Dit resultat is in overeensteming met de bevindingen van vermeulen et al. (1978). Voor alle andere benutte herstelmaten zijn geen statistisch aantoonbare verschillen in het verloop tussen revalidatie- en kontrolegroep gekonstateerd. Wel werd de indruk verkregen, dat de partners van de gerevalideerde patienten, in vergelifking met die van de patienten uit de kontrolegroep, zich meer bekommerden on het lot van hun man en dat de revalidatie mogelijk versterkend werkt op een aanmoedigende houding.

Warom heeft de revalidatie niet de verwachte positieve effekten opgeleverd? Gezien de gepresenteerde resultaten dient dit probleem op twee manieren benaderd te worden:

1. Is er een verklaring voor, dat de revalidatiegroep in bifna alle opzichten een ongunstiger startpositie heeft dan de kontrolegroep?

2. Is ex een verklaring voor, dat het herstel in de revalidatiegroep in het algemeen ongunstigex verloopt dan in de kontrolegroep? 
De neest direkte weg om de eerste vraag te beantwoorden is na te gaan of de revalidatiegroep zich op een aantal beginkenmerken -anders dan de gebruikte herstelmaten- ongunstig onderscheldt van de kontrolegroep. In hoofdstuk 3.2 is al voor een groot aantal kenmerken nagegaan of dit het geval is. Een bevinding die hier gememoreerd kan worden is dat zich in de revalidatiegroep naar verhouding meer patiënten met een recidief infarct bevinden dan in de kontrolegroep (4 tegen 1). Bij een nadere speurtocht in de CCU-gegevens blijkt nog een tweede verschil ten nadele van de revalidatiegroep te bestaan: er bevinden zlch meer patiënten met een vergroot hart dan in de kontrolegroep ( 6 tegen 2 ). Dit gegeven is afgeleid uit de thorax-foto die vlak voor het ontslag uit het ziekenhuis werd genomen. Van een te groot hart is in het CCU-protokol sprake wanneer de hartthorax ratio niet duidelijk kleiner is dan 50\%. Een te groot hart wordt in het algemeen gezien als een aanwijzing voor de verminderde pompfunktie van het hart. In de revalidatiegroep gaat de hartvergroting in twee gevallen samen met een recidief infarct, zodat hiler in totaal van acht patiënten met een te groot hart en/of recidief infarct sprake is, tegen in de kontrolegroep drie. Wanneer echter de gegevens van deze acht respektievelijk arie patiënten uit de beginmeting worden verwijderd, blijven de verschillen tussen beide groepen in dezelfde richting bestaan. Hoewel ex dus aanwijzingen zijn dat de revalidatiegroep er in cardiaal opzicht minder gunstig aan toe is dan de kontrolegroep, blijkt anderzijds dat dit gegeven niet direkt verantwoordelijk is voor de gekonstateerde verschillen.

Een tweede verklaring voor de ongunstige startpositie van de revalidatiegroep zou het zogenaamde pretest-sensitizationeffekt kunnen zijn. Het besef gerevalideerd te gaan worden kan leiden tot een versterking van het gevoel patient te zijn en bijgevolg tot het idee er minder gunstig aan toe te zijn. zelfs als men aanneemt dat de revalidatie dit gevoel versterkt, dan nog mag men aannemen dat het onwaarschijnlijk is dat dit effekt eén en twee jaar na het infarct nog doorwerkt. Daar de revalidatiegroep echter op alle meettijdstippen, ook op én en twee jaar na infarct, systematisch minder gunstig is dan de kontrolegroep, moet deze verklaring als onwaarschijnlijk worden verworpen. 
Het verschijnsel van het relatief ongunstige verloop van het herstel in de revalidatiegroep kan worden ulteengelegd in drie problemen:

a. Waarom zijn er naast het fysieke trainingseffekt geen effekten gekonstateerd voor psychisch en sociaal herstel?

b. Is de aanwijzing dat de revalidatiegroep er in cardiaal opzicht minder gunstig aan toe is een verklaring voor het verschil in verloop?

c. Is het tijdstip waarop de revalidatie begon (drie maanden na infarct) een verklaring voor het verschil in verloop?

Men zou kunnen beweren dat van een revalidatieprogramma, dat wel niet uitsluitend, maar toch in hoofdzaak, bestaat uit fysieke training, behalve een trainingseffekt, niet ook nog effekten op psychisch en sociaal herstel verwacht kunnen worden. Daar staat tegenover dat de hier gebruikte herstelindikatoren allen betrekking hebben op het koncept fysieke aktiviteiten. Als het $z o$ is dat door fysieke tralning de angst voor inspanning verminderd casu quo het zelfvertrouwen verbeterd wordt, dan is het toch niet onredelijk te veronderstellen dat een trainingswinst kan leiden tot een verhoogde gepercipieerde inspanningstolerantie en wellicht tot een verhoogde mate van aktiviteiten in het dagelijks leven. Op zijn minst zou dan toch een positieve invloed waarneembaar moeten zijn in termen van subjektief herstel. Op geen van de genoemde aspekten kon echter een effekt van revalidatie worden aangetoond.

Bij een nadere analyse van het verloop in herstel, rekening houdend met de acht respektievelijk arie patiënten die een recidief infarct en/of een te groot hart hadden, blijkt geen ander beeld dan het reeds geschetste naar voren te komen, met éér uitzondering. De aktiviteitsgraad van de revalidatiegroep komt twee jaar na infarct dichter bij die van de kontrolegroep. Het feit dat het verschil in cardiale toestand tussen patiënten uit de revalidatie- en kontrolegroep niet duidelijk van invloed is op het verschil in herstel tussen beide groepen, kan ook worden geillustreeerd aan de hand van het herstel van de elf minder gunstige gevallen. Van de acht 'ongunstige" gevallen uit de revalidatiegroep maken er twee een in alle opzichten gunstig herstel door, twee zijn en blijven ongunstig, terwijl de vier overigen een tussenpositie innemen. Van de drie ongunstige gevallen uit 
de kontrolegraep is er een die een redelijk herstel te zien geeft, terwijl er twee ongunstig zijn en blijven.

Het tijdstip van de aanvang van de revalidatie drie maanden na infarct, zou als te laat kunnen worden bestempeld. Uit het CARGO-onderzoek is gebleken, dat een vroege fysieke training ( $<2$ maanden na infarct) positieve effekten heeft op de hervatting, de mate van hervatting en het gevoel van algemene tevredenheid. Daarentegen waren er in het Leidse onderzoek aanwijzingen dat de revalidatie wel eens verstorend zou kunnen werken op het sociale herstel, met name op de werkhervatting, een verschijnsel dat ook door vermeulen et al. (1978) werd gekonstateerd. Men zou dan de volgende redenering kunnen opbouwen. Gesteld dat in de eerste paar maanden na infarct vooral het fysieke en het psychische en pas daarna het sociale herstel voorop staat, dan is een laat revalidatieprogramma met fysieke training als het ware 'uit fase' met het normale herstelproces en wordt de ondersteunende rol van het sociale herstel voor verder fysiek en psychisch herstel door de revalidatie negatief beinvloed. De resultaten van de samenvattende analyse zijn met deze redenering zeer wel te verenigen. Men moet wel voor ogen houden dat het pure feit van deelname aan de revalidatie een verklaring kan zijn voor de lagere participatie aan het huishouden en de aktieve vrijetijdsbesteding zoals die gevonden werden voor zes maanden na infarct. Gezien het feit dat ook na dit tijastip geen verbetering op deze aspekten waaxneembaar is, moet toch worden aangenomen dat het hier een 'echt' verschil van de kontrolegroep betreft.

Voor de verklarlng van de gekonstateerde verschillen tussen revalidatie- en kontrolegroep blijuen al met al twee zaken overeind: ten eerste kan men zich niet aan de indruk onttrekken dat de revalidatiegroep ex in cardiaal opzicht minder gunstig aan toe was dan de kontrolegroep. De konklusie is dat de randomisering in deze betrekkelijk kleine onderzoeksgroep toevallig heeft geleid tot een ongunstiger startprofiel van de revalidatiegroep. Met nadruk zij er hier op gewezen dat de behandelende cardiologen op geen enkele wijze invloed hebben kunnen uitoefenen op de randomisering, deze werd puur administratief afgehandeld. Het feit dat de revalidatiegroep in cardiaal opzicht minder 
gunstig startte, bleek overigens geen bevredigende verklaring voor zowel het verschil in startpositie als voor het verschil in verloop. Daannaast is er de suggestie dat deze betrekkelijk late revalidatie mogelijk verstorend werkt op het sociale herstel. Bij het trekken van een algemene konklusie moet men echter voorzichtig zijn. Het is bijvoorbeeld onjuist te konkluderen dat met dit onderzoek is aangetoond dat een revalidatieprogramma zoals dat van Katwijk geen zin heeft. De konklusie luidt veeleer dat voor een groep hartinfarctpatiënten, waarin de ernst van de aandoening varieerde van licht tot matig, geen positieve effekten van het omschreven revalidatieprogramma konden worden aangetoond bij een start van het programma drie maanden na infarct. 


\section{Werkhervatting, revalidatie en coping-strategie.}

\subsection{Inleiding}

In het voorafgaande is meermalen gesteld dat niet zinvol over herstel gesproken kan worden zonder het al of niet hervatten van het werk in de analyse te betrekken. Dit geldt zeker voor herstel in termen van de aktiviteltsgraad, vrijetijdsbesteding, participatie aan het huishouden en de dagindeling. Uit het CARGO-onderzoek bleek bovendien dat werkhervatting de belangrijkste faktor is in de verklaring van het subjektieve herstel.

Het is daarom van belang de interaktie tussen revalidatie en werkhervatting aan een nadere analyse te onderwerpen. Tenslotte zal worden ingegaan op de faktoren die werkhervatting beinvloeden. Deze analyse kan beschouwd worden als een aanvulling op die uit het CARGO-onderzoek, waar immers alleen objektieve variabelen konden worden gebruikt.

\subsection{Revalidatie en werkhervatting}

Bij een analyse naar de differentiele effekten van revalidatie voor hervatters en niet-hervatters gaat het uiteraard in eerste instantie niet om een vergelijking van de groep hervatters met de niet-hervatters, maar om een vergelijking tussen de hervatters uit revalidatie- en kontrolegroep enerzijds en tussen de niet-hervatters uit beide groepen anderzijds. Vanzelfsprekend krijgt men uit de verschillen tussen hervatters en niethervatters wel. een indruk over de faktoren die met hervatting samenhangen. Nu reeds kan worden vermeld, dat met name leeftijd met hervatting samenhangt: patiënten die uiteindelijk het werk hervatten zijn gemiddela 8 jaar jonger dan zij die dat niet doen (49 versus 57 jaar). Beroep en angina pectoris vertonen in dit onderzoek geen sterke relaties met hervatting, zij het dat ze wel in de verwachte richting liggen.

Bij de analyse van de effekten van revalidatie zal worden ingegaan op de objektieve herstelmaten. Om presentatie-technische redenen zal worden volstaan met een grafische weergave van het verloop voor deze maten, met uitzondering van de dagindeling die een aparte behandeling zal krijgen.*)

*) De verdelingskenmerken van de betreffende variabelen vindt men in bijlage 12 . 
a. Wat betreft de maximale inspanningstolerantie (figuux 8.a) zien we bij zowel de hervatters als de niet-hervatters, elk op hun eigen niveau, het eerder vermelde trainingseffekt na de revalidatie. Echter, bij de niet-hervatters treedt een verdergaande verslechtering op in de revalidatiegroep, terwijl in de kontrolegroep juist een stijgende tendens waarneembaar is. De gerevalideerde hervatters lopen na de revalidatieperiode in de pas met die uit de kontrolegroep. Gezien het feit dat de maximale hartfrekwentie (figuur 8.b) voor de gerevalideerde hervatters 12 en 24 maanden na infarct gemiddeld gelijk is gebleven, terwijl die in de kontrolegroep in deze periode 1 icht gestegen is. kan men stellen dat de lichamelijke fitheid in de revalidatiegroep iets beter op peil blijft dan in de kontrolegroep. Voor de niet-hervatters zien we eerder het ongekeerde voor de periode 12 tot 24 manden na infarct: de kontrolegroep presteert bij gemiddeld ongeveer gelijke hartfrekwentie meer, de revalidatiegroep bij eveneens gelijke hartfrekwentie minder.

b. De aktiviteitsgraad (figuur 8.c) geeft voor de hervatters uit revalidatie- en kontrolegroep tussen 3 en 12 maanden ongeveer hetzelfde beeld, zij het dat ale ult de revalidatiegroep in eerste instantie een diepere inzinking vertonen. Daarna maken de hervatters uit de kontrolegroep, in tegensteliing tot die van de revalidatiegroep, nog een verdere stijging door, een effekt dat kan worden herleid tot het feit dat in de eerstgenoemde groep meer, en meer volledige hervatting gerealiseerd wordt.

Bij de niet-hervatters in de revalidatiegroep is tussen drie en zes maanden zelfs nog een daling van het aktiviteitenniveau te konstateren, terwijl in de kontrolegroep de stijging die zich doorzet tot 24 maanden al begonnen is. Opwallend is ook dat in de revalidatiegroep na twalf maanden geen verdere stijging optreedt.

c. De subjektieve belasting toont geen a anmerkelijke verschillen in verloop bij hervatters en niet-hervatters (Eiguur 8.d). Het beeld is kongruent met dat var de gepercipieerde inspanningstolerantie, zij het dat het niveauverschil tussen revalidatie- en kontrolegroep bij de niethervatters vrijwel afwezig is.

d. De gepercipieerde inspanningstolerantle (PET) beweegt zich voor de hervatters op een systematisch hoger niveau dan die van de niet-hervatters. Bovendien blijkt in de groeo 
hervatters reeds tussen drie en zes maanden een stijging op te treden, iets wat bij de niet-hervatters eerst na zes maanden optreedt. Voor zowel hervatters als niet-hervatters geldt dat de kontrolegroep in het algemeen hoger scoort dan de revalidatiegroep (flguur 8.e)

e. De participatie aan het huishouden (figuur 8 .f) vertoont voor de hervatters van de kontrolegroep eerst een stijging, waarna een geleldelijke daling inzet. In de revalidatiegroep blijft de participatie, die eenzelfde beginniveau heeft als in de kontrolegroep, in het eerste jaar konstant en toont dan pas een stijgende lijn. Bij de niet-hervatters (figuur $8 . h$ ) zien we in de revalidatiegroep, vanaf een relatief laag beginniveau, een stijging van drie naar twalf maanden. In de kontrolegroep valt een stijgende lijn vanaf zes maanden war te nemen. Uiteindelijk is de participatie in de kontrolegroep hoger dan in de revalidatiegroep. In overeenstemming met de resultaten van hoofastuk 6.7 blijkt het niveau van de niet-hervatters op dit punt hoger te liggen dan dat van de hervatters.

f. De scores van de aktieve vrijetijdsbesteding (figuur 8.g) vertonen voor de hervatters in beide groepen hetzelfde verloop, met dien verstande dat de hervatters uit de kontrolegroep systematisch hoger scoren dan die uit de revalidatiegroep. Verder moet nog worden opgemerkt dat de spreiding om het gemiddelde in de revalidatiegroep groter is dan in de kontrolegroep. Voor de niet-hervatters gelden in princlpe dezelfde opmerkingen. De scores van de niet-hervatters 1iggen in het algemeen onder die van de hervatters, met een verschijnsel dat ook al werd gekonstateerd bij de samenvattende analyse in 6.7 .

Wat betreft de dagindeling kan vermeld worden dat het verloop bij de niet-hervatters in revalidatie- en kontrolegroep vrijwel gelijk lis. Voor de hervatters geldt, gezien het feit dat in de kontrolegroep meer, en meer gehele hervatting plaats vindt, dat in deze groep de kontrakteerde tijd hoger uitvalt dan in de revalidatiegroep $(9.6$ tegen 6.4 uur). Voor de eindtoestanden van de niet-hervatters in beide groepen valt een vergelijking te maken met de cijfers van knulst (1977) betreffende de dagindeling van gepensionneerde en werkloze mannen (tabe1 7.1).

Het aantal uren besteed aan de vrije tijd vertoont een redelijke overeenkomst. De niet hervatte hartpatienten gunnen $z i c h$ 


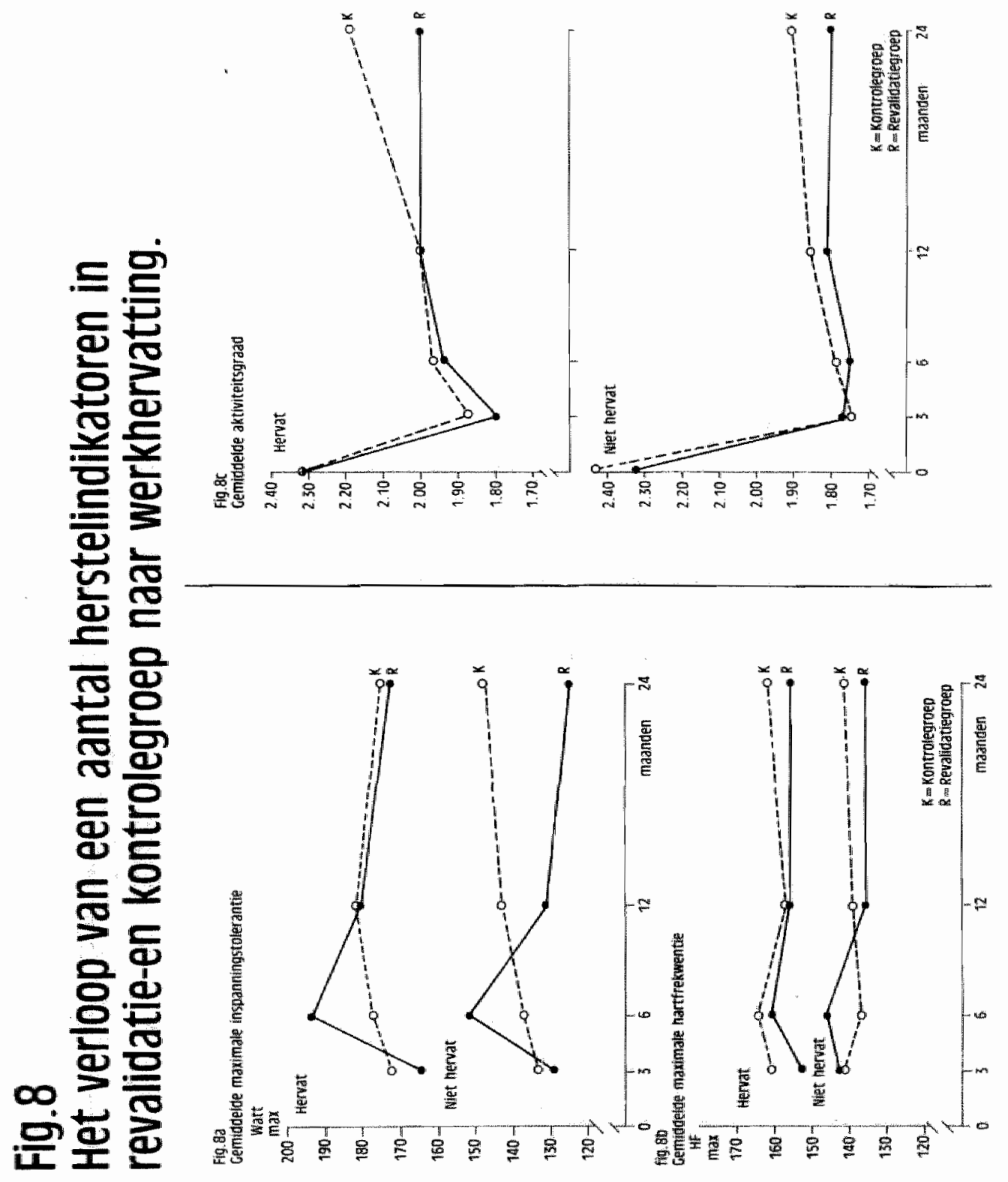



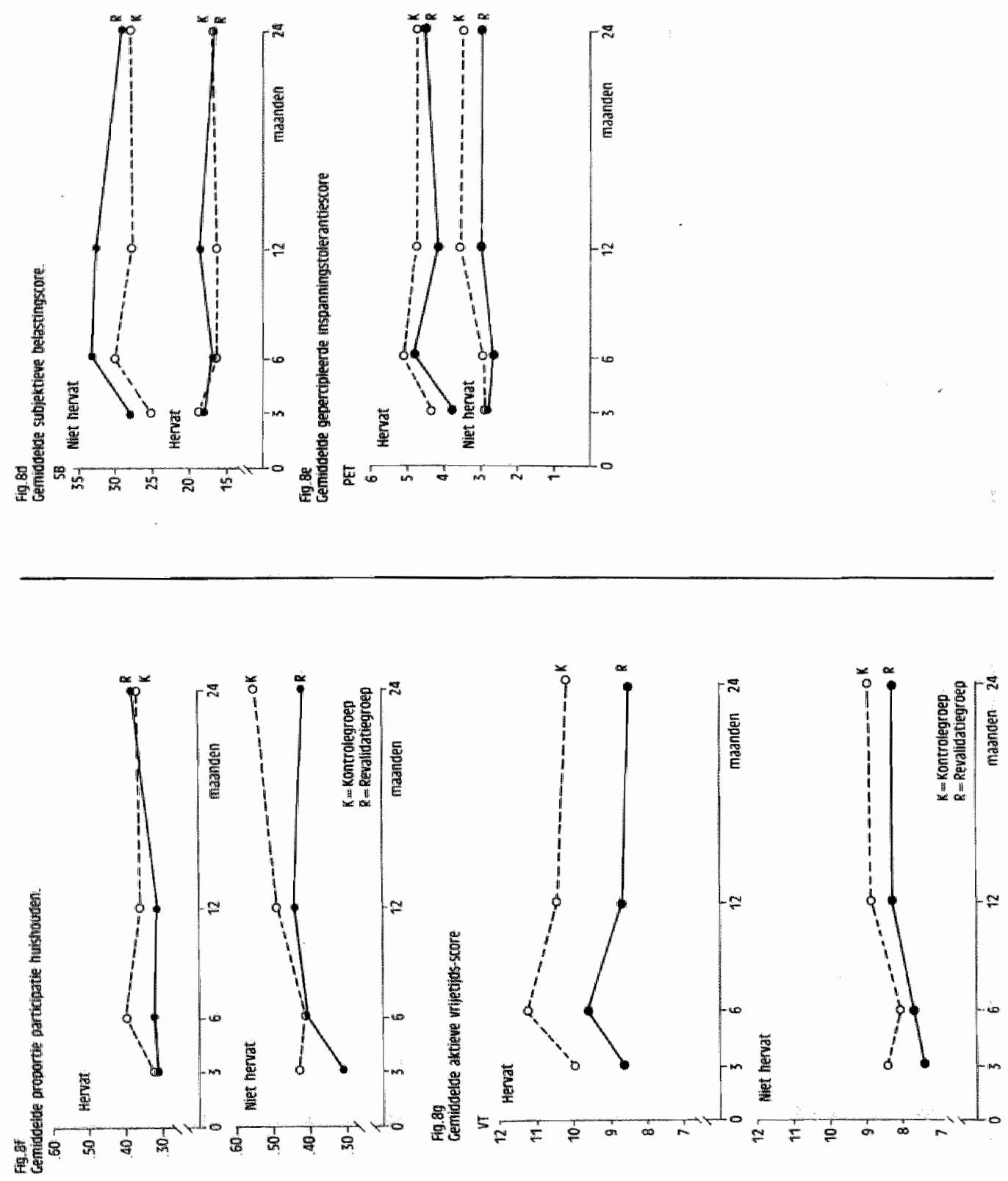
echter minder rust en leggen zichzelf meer aktiviteiten op, dan gepensionneerde en werkloze mannen.

Pabel 7.1: De dagindeling van de niet-hervatters in revalidatie- en kontrolegroep vergeleken met die van gepensionneerde en werkloze mannen (knulst, 1977) (in uren gemiddeld)

revalidatie kontrole gepension. werkloos

\begin{tabular}{lcccc}
\hline noodzakelijke tijd & 9.5 & 9.9 & 11.6 & 11.7 \\
gekontrakteerde tijd & 0 & 0 & 0 & 0 \\
zelf opgelegde tijd & 3.5 & 3.9 & 2.3 & 2.3 \\
vrije tija & 11.0 & 10.2 & 9.4 & 10.0 \\
\hline
\end{tabular}

In het algemeen gesproken lijkt het verloop op de onderscheiden herstelindikatoren niet veel te verschillen tussen de hervatters van revalidatie- en kontrolegroep, behalve wat betreft de aktiviteitsgraad en de aktieve vrijetijasbesteding. Daar in de kontrolegroep meer, en meer volledige hervatting plaats vindt, stijgt de aktiviteitsgraad sterker, terwijl de hervatters uit de kontrolegroep van meet af aan een aktievere vrijetijasbesteding hebben dan die uit de revalidatiegroep. De niet-hervatters uit de revalidatiegroep zijn uiteindelijk op drie aspekten ongunstiger af dan die van de kontrolegroep: het maximale inspanningsvermogen, de aktiviteitsgraad en de participatie in het huishouden. De konklusie luidt dat over het geheel genomen geen sprake is van beduidende interaktie-effekten tussen revalidatie en werkhervatting.

7.3 Faktoren die met werkhervatting samenhangen: coplngstrategie

Wanneer men heden ten dage bij een onderzoek onder hartinfarctpatiënten een persoonlijkheids-achtüg kenmerk invoert, zal zondex twijfel de keus vallen op de $\mathrm{A} / \mathrm{B}$ typologie en dan met name gemeten door middel van de Jenkins Activity Survey (Jenkins et al. r 1974). In de traditie waarin dit onderzoek is opgezet, zijn echter andere persoonlijkheids- 
testen gebruikelijk geweest. Zo werden hier als kontrolevariabelen de van de $A B V$ (Wilde, 1970) afkomstige neuroticismeen extraversieschal gebruikt, met name omdat Josten (1970) op basis van deze twee schalen een typologie van copinggedrag had ontwikkeld, die van voorspellende betekenis leek te $z i j n$ voor herstel na hartinfarct. De typologie is gebaseerd op de waarneming dat de neuroticisme-scores en, in mindere mate ook de extraversie-scores, in Josten's onderzoek een bimodale verdeling vertoonden. Op basis hiervan verdeelde hij zijn onderzoeksgroep in arie groepen:

1. Patiênten met een neuroticisme-score onder en een extraversle-score boven de mediaan. Deze groep kenmerkt zich door een geringe neiging tot tobben en klagen en door een sterke gerichtheid op de omgeving. Zich voordoende problemen worden gekompartimentaliseerd tot specifieke probleemsituaties (kompartimentalisatie-groep).

2. Patiẽnten met een neuroticisme-score boven, en een extxaversiescore onder de mediaan kunnen worden gekenmerkt als patienten met een sterke neiging tot tobben en klagen en een beperkte gerichtheid op de omgeving. Het gedrag koncentreerd zich op persoonlijke problemen, waarbij de tendens kan optreden dat steeds meer situaties als problematisch worden ervaren (generalisatie-groep).

3. Patiënten met neuroticisme- en extraversie-scores boven de mediaan enerzijds en onder de mediaan anderzijds, kunner worden gekenmexket als een groep warbij een duidelijke strategie ontbreekt. Josten veronderstelde dat deze situatie op den duur in één van de eerder genoemde strategieën zal overgaan (vaccilatie-groep).

Bij deze typologie zijn een drietal opmerkingen te maken. Om te beginnen is de term 'strategie' een wat minder gelukkige keuze, daax in het algemeen geen sprake is van een bewuste afweging van gedragsalternatieve doox de patiënt. Ten aanzien van de vaccilatie-groep kan worden opgemerkt, dat moeilijk in te zien valt welke a-priori rechtvaardiging kan worden gegeven om patiênten met voor belde kenmerken hoge en die met voor belde lage scores, als een groep te beschouwen. Hier zal de bedoelde groep dan ook als een tussengroep worden beschouwd, waarover men in termen van coping-strategie geen uitspraak kan doen. Uit het onderzoek van Josten bleek dat de vaccilatiegroep op alle door hem benutte kenmerken, met uitzondering van het voórkomen van angina pectoris, een midden- 
positie innam.

Het is, met andere woorden, empirisch verdedigbaar, de vaccilatiegroep als tussengroep te beschouwen. De latste opmerking geldt de eventuele overeenkomsten tussen deze typologie en de A/B typologie. Het is aannemelijk dat type A-gedrag verwantschap vertoont met wat hier kompartimentalisatie is genoemd.

De typologie van Josten wordt hier geintroduceerd om twee redenen. Ten eerste bleek een samenhang te bestaan tussen coping-gedrag en werkhervatting: de K(ompartimentalisatie)groep had het hoogste hervattingspercentage, de G(eneralisatie)-groep het laagste, terwijl de $V$ (accilatie)-groep een middenpositie innam. Vervolgens doet zich in het huidige onderzoek de mogelijkheid voor de veronderstelde instabiliteit van de $V$-strategie, en de stabiliteit van $\mathbb{K}$ - en $G$ strategie, in een longitudinale opzet te toetsen. De analyse van het laatst genoemde probleem zal allereerst ter hand worden genomen voor de gehelle groep. De gevolgde procedure is dat op elk meettijdstip de respektieve medianen van neuroticisme- en extraversie-scores zijn bepaald. op basis hiervan zijn de patiënten ingedeeld in de drie typen coping-strategie. De bimodale verdeling in de $\mathrm{N}$-scores treedt inderdaad op. Bij de E-scores is de bimodaliteit, evenals bij Josten, minder uitgesproken, maar wel aanwezig. Wanneer het verloop in de verdeling van de patienten over de coping-strategieën en de proporties die konstant blijven tussen de metingen bezien worden (tabe1 7.2), valt op te merken dat de veranderlijkheid in het algemeen niet exg groot is, als men bedenkt dat de proportie konstant alleen al op grond van het toeval . .33 is.

Wel is duidelijk dat de vaccilatiegroep het minst stablel 1s: In de eerste negen maanden daalt het aantal patieñten in deze kategorie ten gunste van beide andere kategorieên. Hoe wel dus niet gesteld kan worden dat vaccilatie instablel is, kan wel worden beweerd dat het de minst stabiele strategle is. Voor de stabilitelt van beide andere strategieen pleit, dat de overgang $K * G$ nooit en de overgang $G \rightarrow K$ slechts tweemal voorkomt. 
Tabel 7.2: Het verloop in de verdeling over drie copingstrategieen $(n=51)$

\begin{tabular}{lllll}
\hline maanden na MI : & 3 & 6 & 12 & 24 \\
\hline K-groep & 15 & 16 & 17 & 16 \\
V-groep & 20 & 18 & 14 & 18 \\
G-groep & 16 & 17 & 20 & 17 \\
proportje konstant: & & & & \\
K-groep & .80 & .88 & .76 & \\
V-groep & .55 & .56 & .64 & \\
G-groep & .69 & .82 & .75 & \\
\hline
\end{tabular}

Een opmerkelijk verschijnsel doet zich voor wanneer het verloop in coping-strategieën voor revalidatie- en kontrolegroep apart wordt bezien. Na zes maanden treedt een verslechtering op in de revalidatiegroep in de richting van generalisatie. omdat op drie en zes maanden nauwelijks verschil bestaat tussen beide groepen, kan hier van een nieuwe aanwijzing worden gesproken voor een verklaring van het ongunstiger verloop van het herstel in de revalidatiegroep. Wanneer werkhervatting in de analyse wordt betrokken, blijkt het effekt voor hervatters en, in sterkere mate voor de niet-hervatters aanwezig te zijn (tabel 7.3). Men zou de verslechtering, voorzover deze betrekking heeft op de niet-hervatters, kunnen interpreteren als het niet ingelost worden van door de revalidatie gewekte verwachtingen.

Tabe] 7.3: Het verband tussen coping-strategie en revalidatie- en kontrolegroep naar werkhervatting ( $\varphi$-koëfficiënten, $\mathrm{K}+\mathrm{V}$ tegen $\mathrm{G}$. Een positief verband duidt op een verdeling ten gunste van de revalidatiegroepl

\begin{tabular}{lcccc} 
maanden na MI: & 3 & 6 & 12 & 24 \\
\hline hervat & -.17 & -.06 & -.25 & -.25 \\
niet hervat & -.12 &.- .04 & -.30 & $\left.-.39^{*}\right)$ \\
totaal & -.04 & -.08 & -.29 & $-.33^{* *}$ )
\end{tabular}

*) $p<.10 * *$ ) $p<.05$ Fisher"s exact prob. toets 
In de verdere analyse zal de coping-strategie worden ingevoerd als semi-konstant persoonlijkheidskenmerk in de vorm van de dominante coping-strategie, dit is het type coplng gedrag dat over de vier metingen gezien, tenminste drie keer voorkomt (tabel 7.4). Deze tabel illustreert nogmaals de relatieve stabiliteit van kompartimentalisatie en generalisatie en de relatieve instabiliteit van de tussenvorm. De zeven patienten die nogal wisselen van strategie zijn, daar een dominante strategie ontbreekt, ingedeeld bij de tussengroep.

Tabe1 7.4: De verdeling van dominante coping-strategieen

\begin{tabular}{lccccc}
\hline & $4 x$ dezelfde & $3 x$ dezelfde & rest & dominant \\
\hline K-strategie & 10 & 5 & $*$ & 15 \\
V-strategie & 5 & 9 & - & $14+7$ \\
G-strategie & 9 & -6 & - & 15 \\
\hline
\end{tabular}

omdat de verdeling van dominante coping-strategieen niet sterk verschilt tussen revalidatie- en kontrolegroep, er is uiteraard wel een klein verschil ten gunste van de kontrolegroep, zal de analyse voor de gehele groep worden uitgevoerd. Aan de hand van een aantal beginkenmerken, kan worden nagegaan in hoeverre een aantal van Josten's bevindingen kunnen worden gerepliceerd (tabel 7.5).

De resultaten ten aanzien van leeftijd en de fysiologische validiteit zijn niet in overeensteming met Josten, de overige wel.

Josten vond geen verband met de leeftijd en wel met de fysiologische valiaiteit, dat wil zeggen in de K-groep was deze het hoogst en in de G-groep het laagst. Het versch1jnsel dat vooral in de vaccilatie-groep het meest AP voorkomt is niet eenvoudig te verklaren. Het zou eerder voor de hand hebben gelegen, op grond van een pasitief verband tussen neuroticisme en AP (Bakker en Levenson, 1967), als het percentage het hoogst was in de G-groep. 
Tabe1 7.5: Beginkenmerken (3 mud. na MI) van patiënten in drie doninante coping-strategiecm

Komp. Vacc. Gener.

\begin{tabular}{|c|c|c|c|c|}
\hline leeftijd $(\bar{x})$ & 49.7 & 52.0 & 55.3 & Krusk.Wallis $p<.10$ \\
\hline fys. validiteit (v) & 95.6 & 93.8 & 93.5 & n.s. \\
\hline subj. belasting & 15.7 & 22.7 & 26.9 & $p<.01$ \\
\hline get AP & 20 & 48 & 27 & 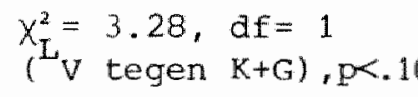 \\
\hline
\end{tabular}

F optimistisch over

toekomst:

gezondheid

87

80

71

52

47

20

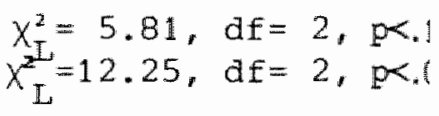

De verklaring zou allereerst kunnen worden gezocht in een eventuele oververtegenwoordiging van patiënten met hoge neuroticisme-scores in de tussengroep. Zoals gezegd, is de tussengroep samengesteld uit patiënten met $\mathrm{N}$ - en $\mathrm{E}-$ scores onder de mediaan $(n=9)$ en uit patiënten met scores boven de mediaan $(n=12)$. In beide groepen komen drie maanden na infarct vijf patiënten met angina pectoris voor, zodat zelfs van een lichte oververtegenwoordiging van AP bij de patiënten met lage scores kan worden gesproken. Dit verschijnsel doet zich in vrijwel dezelfde mate voor bij de vervolgmetingen. De gemengde samenstelling van de vaccilatie-groep biedt dus geen verklaring voor de hogere incidentie van AF in deze groep. Een andere verklaring kan worden gevonden uitgaande van de konstatering dat, door de gehanteerde contra-indikaties, in de onderzoeksgroep ernstige angina pectoris niet voorkomt. De angina pectoris die in de onderzoeksgroep voorkomt, aanvalsgewijs met waarschijnlijk langere tussenperioden, kan ertoe leiden dat de patiënt zich afwisselend redelijk goed en tamelijk slecht kan voelen. bit kan dan remmend werken op een stabiele aanpassing aan de ziekte.

Omdat leeftijd samenhangt met dominante coping-strategie, hoe ouder hoe ongunstiger de strategie, moeten de andere resultaten worden gekontroleerd op de invloed van leeftijd. 
Wanner we dit probleem benaderen met behulp van partielle korrelatierekening, blijken de verbanden tussen copingstrategie en respektievelijk subjektieve belasting, optimisme gezondheid en werk, alle te blijven bestaan wanneer leeftijd konstant wordt gehouden (na partialisering respektievelijk $-.35, .29, .47$ ).

De dominante coping-strategie blijkt een voorspellende waarde te hebben voor zowel objektief als subjektief herstel. Wanneer we als indikator voor objektief herstel werkhervatting, en voor subjektief herstel de tevredenheid over de gezondheidstoestand nemen, ontstaan vooral ten aanzien van het subjektieve herstel aanzienlijke verschillen tussen de groepen. Voor werkhervatting boet het verband aan kracht in, wanneer leeftijd, die sterk negatief samenhangt met hervatting $(x=-.58)$, konstant wordt gehouden (tabel 7.6 ).

Tabel 7.6: Werkhervatting en tevredenheid gezondheid naar dominante coping-strategie $(\mathrm{n}=51)$

is hervat

sevreden met gezondheid

( 24 mnd)

(3. mand)

(24 mnd)

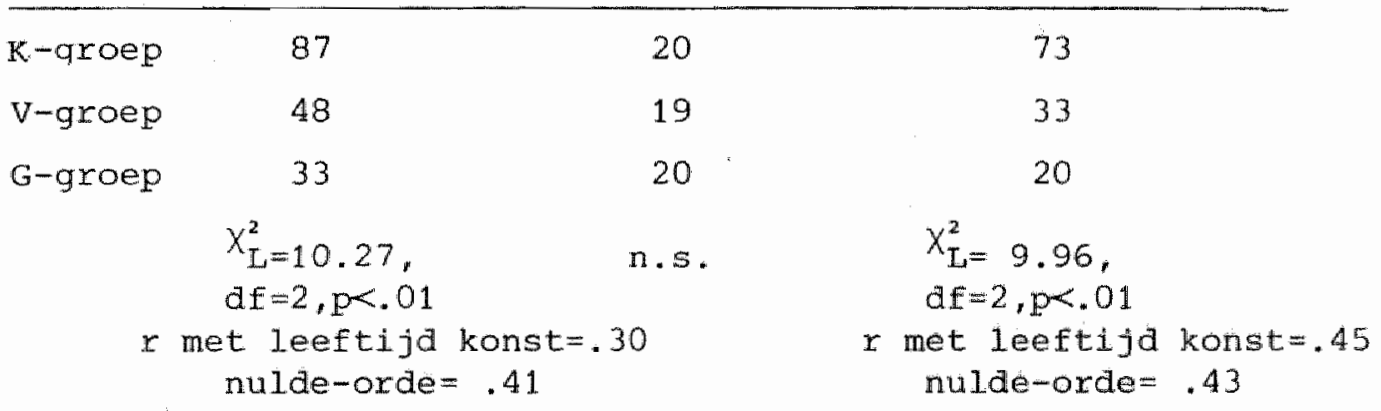

7.4 Samenvattende analyse wexkhervatting in het Leidse onderzoek

De analyse van de met werkhervatting samenhangende faktoren

in het Leidse onderzoek kan worden gezien als een acinulling op aie van het CARGo-onderzoek. In het laatst genoemde onderzoek kon immers niet worden beschikt ovex zulke gedetailleerde informatie omtrent de fysieke en psychische toestand van de patiënten als in het Leidse onderzoek. Om de vergelijk- 
baarheid met de analyse van het CARGO-onderzoek zo groot mogelijk te maken, zal getracht worden werkhervatting te voorspellen vanuit de toestand van drie maanden na infarct. met in achtname van de drie belangrijkste voorspellers van het CARGO-onderzoek (Leeftijd, beroep en angina pectoris). In het voorafgaande zijn een aantal faktoren ter sprake gekomen die in aanmerking komen als potentiële voorspellers van werkhervatting. In tabel $7.7 \mathrm{zijn}$ deze naar sterkte van het verband met hervatting weergegeven.

Tabe 1 7.7: Potentiële voorspellers ( $3 \mathrm{mnd}$. na MI) van werkhervatting (24 mnd). Leidse onderzoek $(n=51)$

\begin{tabular}{|c|c|c|c|}
\hline & $\begin{array}{l}\text { nulde-orde } \\
\text { korrelatie }\end{array}$ & $\begin{array}{l}\text { tweede-orde } \\
\text { (leeftijd, } \\
\text { PET }_{3} \text { konstant) }\end{array}$ & $\begin{array}{l}\text { vijfde-orde } \\
\text { overigen } \\
\text { konstant }\end{array}$ \\
\hline leeftijd & -.58 & -- & -.50 \\
\hline $\mathrm{PET}_{3}$ & .57 & -- & .36 \\
\hline $\mathrm{SB}_{3}$ & -.47 & -.12 & -.04 \\
\hline $\begin{array}{l}\text { toekomstverwachting } \\
\text { werk }_{3} \text { (pess.-optim.) }\end{array}$ & .45 & .28 & .17 \\
\hline dominante coping-str. & .41 & .18 & .17 \\
\hline fysiol & $\ldots .32$ & .23 & $\therefore 21$ \\
\hline beroep & .23 & $-\cdots$ & -- \\
\hline angina pectoris & -.20 & -- & -- \\
\hline 5: grens & $r=.27$ & .27 & .29 \\
\hline
\end{tabular}

Van de drie belangrijkste voorspellers uit het CARGO-onderzoek blijkt alleen leeftijd hier samen te hangen met hervatting. Beroep en angina pectoris hangen wel in de verwachte richting samen met hervatting, maar de korrelaties bereiken geen signifikante waarde. Een verklaring hiervoor kan zijn dat in het Leidse onderzoek voor deze twee variabelen, in vergelijking met het CARGO-onderzoek, een restriction of range is opgetreden: het hoogste beroepsniveau is dat van 
middelbare employee, terwijl patienten met ernstige angina pectoris niet in het onderzoek kwamen door de gehanteerde contra-indikaties.

Leeftijd en perceptie van het fysieke kunnen (PEI) dxie maanden na infarct blijken de krachtigste voorspellers te zijn, en wel zodanig dat alle andere potentiele voorspellers -met uitzondering van de toekomstverwachting werk- het laten afweten wanneer deze beide faktoren konstant worden gehouden. Wanneer de korrelatie van de voorspellers met hervatting wordt berekend onder konstant houden van alle overige, blijven leeftija en $\mathrm{PET}_{3}$ zelfs als enige over. Het lijkt er dus op dat de analyse in dit onderzoek een ander resultaat gaat opleveren dan in het CARGo-onderzoek. Een nadere beschouwing van de onderlinge verbanden tussen de onafhankelijken, lat echter zien dat er een dusdanig verwevenheid bestaat, dat verondersteld kan worden dat beroep en angina pectoris dan wel niet direkt met hervatting samenhangen, maar hun invloed via met name de gepercipieerde inspanningstolerantie zou kunnen lopen (figuur 9).

Figuur 9 : onderlinge relaties tussen de onafhankelijke variabelen met betrekking tot hervatting (alleen signifikante korrelaties $5 \%$ )
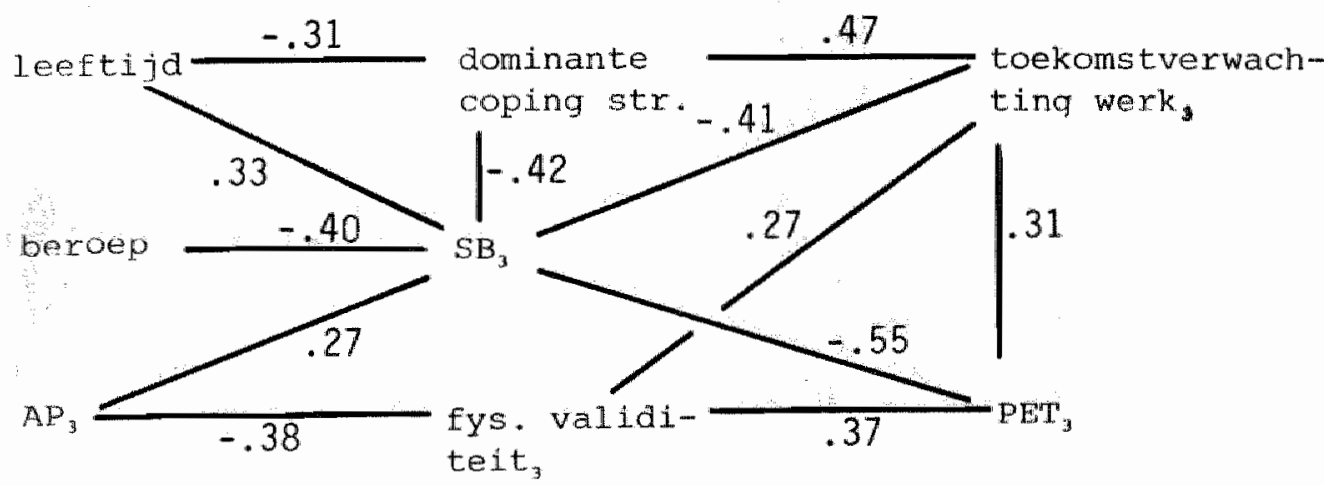

Binnen de onafhankelijke variabelen 1 ijkt een centrale rol te zijn weggelegd voor de subjektieve belasting. Een hogere leeftijd, een laag beroep en angina pectoris aragen bij tot een hogere mate van subjektieve belasting. 
Subjektieve belasting staat op zijn beurt weer in nawwe relatie met zowel coping-strategie, toekomstverwachting werk en gepercipieerde Inspanningstolerantie: hoe hoger de subjektieve belasting, hoe ongunstiger de copingstrategle, hoe pessimistischer de toekomstverwachting ten aanzien van hervatting en hoe geringer de dunk van het eigen Eysieke kunnen.

Over de relaties tussen de onafhankelijke variabelen kunnen nog twee opmerkingen gemaakt worden. voorzover in het materiaal van de 125 in 1973 te katwijk gerevalideerde hartinfarctpatienten dezelfde variabelen zijn gebruikt, valt op te merken dat de korrelaties tussen subjektieve belasting met beroep, leeftijd en angina pectoris en die tussen angina pectoris en fysiologische validiteit, een sterke gelijkenis vertonen met de hier gevonden warden. Deze bevinding pleit voor de stablitteit van de genoemde relaties. Wanneer tenslotte de variabele revalidatie- of kontrolegroep als dummy wordt ingevoerd blijkt deze geen rol van betekenis te spelen, het enige noemenswaardige verband is dat met de dominante coping-strategie (-.20) .

Omdat het behoren tot revalidatie- en kontrolegroep nauwelijks voorspellend is voor hervatting, zal deze variabele niet in de verdere beschouwingen worden betrokken.

Ter afsluiting van dit betoog zal met behulp van pad-analyse een model worden gekonstrueerd, waarin werkhervatting 24 manden na MI kan worden voorspeld met de genoemde onafhankelijke variabelen. voor de konstruktie van een model hebben de volgende uitgangspunten gediend.

Om de vergelijkbaarheid met het CARGO-onderzoek te waarborgen en gezien de onderlinge relaties tussen de onathankelijken, ligt het voor de hand leeftija, beroep en angina pectoris als exogene variabelen in het te ontwikkelen model op te nemen. Op basis van de resultaten van de partiele korrelatie-analyse (tabel 7.7) is men vervolgens genoodzaakt alleen leeftijd en de gepercipieerde inspanningstolerantie direkt met hervatting in verband te brengen. Tenslotte kunnen angina pectoris en dominante coping strategie, op grond van het kromlijnige verband tussen beide, niet in én model worden ondergebracht. Het blijkt om te beginnen niet mogelijk een bevredigend model op te stellen warin coping-strategie en/of toekomstverwachting werk voorkomen. De resultaten van de partiële korrelatie-analyse uit tabel 7.7 wijzen trouwens al in die 
richting. Een bevredigend model is wél op te stellen met de overige variabelen (figuur 10).

Eiguur 10: Pad-diagram voorspelling werkhervatting in het Leidse onderzoek $(n=51)$.

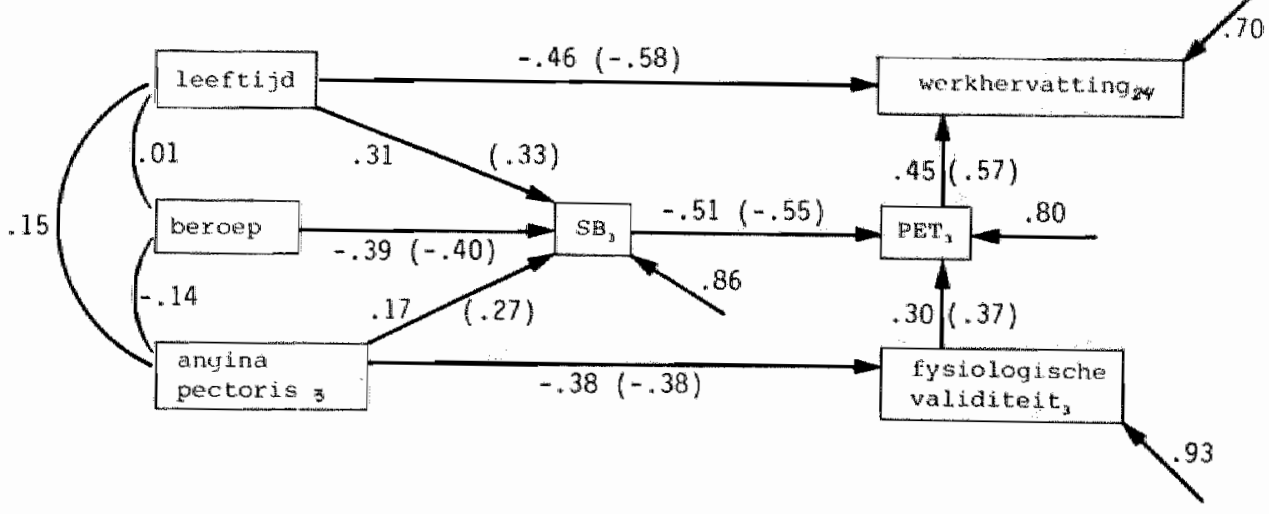

(Bij de pijlen zijn de pad-koëfficiënten met tussen haakjes de nulde-orde korrelaties vermela.)

Om de adekwaatheid van het model -in statistisch opzicht- te toetsen, moet men zich de vraag stellen of bepalde verbanden terecht op nul zijn gesteld. Dit probleem kan op twee manieren worden benaderd: ten eerste moet men eisen dat de verklaarde variantie van de onafhankelijke door de direkt be Invloedende variabelen (in dit geval leeftijd en $\mathrm{pET}_{3}$ ) even groot is als die door alle variabelen te zamen; ten tweede moet op basis van het model de oorspronkelijke korrelatiematrix kunnen worden gereproduceerd. Dit laatste is vanzelfsprekend het geval voor de reeds berekende pad-koëficiënten, die immers rechtstreeks uit de korrelaties berekend zijn. Ten aanzien van de in het model ontbrekende relaties kunnen de korrelaties op basis van het model worden voorspeld. Een vergelijking met de feitelijke korrelaties geeft dan een gedetallieerde indruk over de adekwatheid van het model (tabe1 7.8 ) (zie McDonald, $1977)$. 
Tabel 7.8: Evaluatie van het model voorspelling werkhervatting (figuur 10).

I. verklaarde variantie met leeftijd en $\mathrm{PET}_{3} \quad \mathrm{R}^{2}=.5049$ verklaarde variantie alle onafhankelijken $\quad R^{2}=.5060$ verschil tussen beide $R^{2}$ is niet signifikant $(F=.02)$

II.vergelijking voorspelde/Feitelijke korrelaties

$\begin{array}{lrrllll}\mathrm{PET}_{3}-\text { leeftijd } & -.17 & -.26 & \text { fys.val. } & \text {-hervatting } & \frac{\mathrm{V}}{17} & \frac{\mathrm{F}}{.32} \\ \mathrm{PET}_{3} \text { - beroep } & .18 & .26 & \text { beroep } & \text {-hervatting } & .11 & .23 \\ \mathrm{PET}_{3}-\mathrm{AP}_{3} & -.25 & -.27 & \mathrm{AP}_{3} & \text {-hervatting } & -.19 & -.20 \\ \mathrm{SB}_{3}-\text { Eys.validiteit }_{3} & -.07 & -.13 & \text { validit., -beroep } & .05 & -.09 \\ \mathrm{SB}_{3}-\text { hervatting } & -.40 & -.47 & \text { validit. } & \text {-leeftijd } & -.00 & -.01\end{array}$

Het model zit er duidelijk naast wat betreft de fysiologische validitelt en werkhervatting: in feite bestaat een signifikante korrelatie van .32 , terwijl het model slechts tot .17 komt. Dit suggereert dat tussen de validiteit en hervatting nog een rechtstreeks verband zou bestaan. Hiertegen pleit dat de verklaarde variantie in hervatting na toevoeging van de validiteit nauwelijks groter wordt.

De overige korrelaties worden door het model redelijk tot goed voorspeld. Het model laat zich op eenvoudige wijze interpreteren. De somatische faktoren doen hun invloed op de kans op hervatting vooral gelden via de perceptie van het fysieke kunnen: angina pectoris via subjektieve belasting en validiteit, en de validiteit rechtstreeks op die perceptie. De faktor beroep is zeer duidelijk verbonden aan de as subjektieve belasting - perceptie fysieke prestatie: patiënten met lagere beroepen voelen zich na infarct zwaarder belast door aktiviteiten in het dagelijks leven, hetgeen weer leidt tot een lagere inschatting van het fysieke kunnen. Een lage inschatting verkleint op zijn beurt weer de kans op uiteindelijke werkhervatting. De invloed van leeftijd loopt vooral rechtstreeks op hervatting, al loopt een deel van de invloed evenals bij beroep via SB en PET. Leeftijd moet hier vooral gezien worden als indikator van sociale leeftijd. De biolo- 
gische leeftija is immers vooral vervat in de -voor kalenderleeftijd gestandaardiseerde- fysiologische valiaiteit. De rechtstreekse invloed van leeftijd op hervatting $\mathrm{kan}$ worden verklaard als men aanneemt dat deze faktor in de werking van de sociale verzekering -en dus de axbeidsmarktlos van andere faktoren een dominante invloed op de herintrede heeft.

Het feit dat geen model kon worden opgesteld met de dominante coping-strategie vereist nog enige toelichting.

Bij een poging toch nog een model te konstrueren worden we gekonfronteerd met twee zaken: ten eexste blijkt een niet signifikante pad-koëfficiënt van coping-strategie naar hervatting te bestaan (.19); ten tweede is men, althans in een rekursief model, genoodzaakt te veronderstellen dat subjektieve belasting de coping-strategie veroorzaakt.

Wanneer men deze onrealistische veronderstelling laat vallen en alleen maar een korrelatie tussen beiden veronderstelt. blijkt een niet identificeerbaar non-rekursief model te ontstaan.

\section{5 samenvatting en diskussie}

Uit het CARGO-onderzoek was al gebleken dat werkhervatting van grote betekenis is voor het herstel na hartinfarct. om die reden werd allereerst voor het Leidse onderzoek nagegaan of sprake was van een interaktie tussen werkhervatting en revalidatie. Dit bleek nauwelijks het geval te zijn. Wel bleken de niet-hervatters uit de revalidatiegroep een ongunstiger herstel te vertonen wat betreft de lichameligke konaitie en de aktiviteitsgraad dan die uit de kontrolegroep. Ter afsluiting is een analyse uitgevoerd naar de faktoren die werkhervatting beinvloeden. Hierblj werd apart ingegaan op de door Josten ontwikkelde typologie van coping-strategieën. De eerder door deze auteur gevonden resultaten konden in belangrijke mate worden gerepliceerd. Een ultvloeisel van deze analyse was de bevinding dat revalidatie de copingstrategie negatief leek te beinvloeden. Dit verschijnsel trad vooral op bij patiennten die het werkniet hervatten. De interpretatie hiervan kan luiden dat vooral voor deze groep patiênten de door de revalidatie gewekte verwachtingen niet ingelost zijn.

Kompartimentalisatie, gebaseerd op lage neuroticisme- en op hoge extraversie-scores, blijkt de gunstigste strategie te 
zijn. Als men aanneemt dat de psychologische make-up van kompartimentaliserende patienten overeenkomt met die van het $A$-type, dan kan men speculeren dat die faktor die bijdraagt tot het optreden van een infarct, een positieve faktor is in het herstel na het infarct. Wanneer echter herstel een terugkeer tot de oude levensstijl zou inhouden, is het anderszins duidelijk dat dit niet zonder meer als positief kan worden gewaardeerd.

Hoewel dominante coping-strategie nauw samenhangt met een aantal potentiële voorspellers van hervatting en in feite ook zelf een potentiële voorspeller is, bleek deze faktor toch niet in een bevredigend kausaal model te kunnen worden opgenomen. Dit hoeft overigens niet te betekenen, dat copingstrategie geen enkele rol speelt bij de voorspelling van werkhervatting. Coping-strategie is immers nauw gerelateerd aan subjektieve belasting, welke variabele wel in een model kon worden opgenomen.

De faktoren die de meeste variantie in werkhervatting verklaren, zijn leeftijd en de gepercipieerde inspanningstolerantie drie maanden na infarct. De invloed van beroep en angina pectoris op hervatting bleek -op basis van een middels pad-analyse ontwikkeld model- te lopen via respektievelijk subjektieve belasting en gepercipieerde inspanningstolerantie drie maanden na infaxct.

Het ontwikkelde model is een duidelijke aanvulling op de eerder gepresenteerde resultaten van het CARGO-onderzoek, omdat het laat zien dat een deel van de verklaring van het al of niet hervatten moet worden gezocht in persoonlijkheidsachtige kenmerken, met name in de perceptie van het fysieke kurnen. 


\section{Samenvatting en diskussie onderzoeksresultaten}

8.1 CARGa-onderzoek

In dit laatste hoofdstuk zulien de samenvatting en diskussie zich op de hoofdlijnen koncentreren, daar in de hoofdstukken $4.7,5.4$ en 5.5 voor het CARGO-onderzoek en in 6.8 en 7.4 voor het Leidse onderzoek, reeds uitvoerige aandacht aan deze punten is besteed.

Wat betreft het beschrijvende deel van het CARGo-onderzoek zal hier eerst worden stilgestaan bij het hervattingspercentage. Hoewel een percentage van $65 \%$ voor Nederlandse begrippen redelijk lijkt, ontkomt men niet aan een aantal nuancerende opmerkingen. Om te beginmen kan worden gesteld dat zo"n overa 11 -percentage verhullend is voor de feitelijke arbeidsinvaliditeit. In dit verband is het goed hier nogmaals te vermelden, dat het percentage patienten dat geheel hervat, dat wil zeggen terugkeert naar werk dat meer dan drievierde van een volledige werkdag beslaat, slechts $37 \%$ bedraagt. Wanneer de eisen hoger worden gesteld en gehele hervatting in eigen werk als criterium wordt genomen, komt men tot $27 \%$. We hebben overigens gezien dat door de patiënten hervatting in eigen werk belangrijker wordt geacht dan gehele hervatting. Met het criterium hervatting in elgen werk wordt een percentage van 44 verkregen. Het is dus in elk geval zo dat slechts voor een minderheid van de overlevende patiënten. een bevredigende hervatting wordt gerealiseerd. vervolgens kan men zich afvragen wat het resultaat met een langere vervolgperiode zou zijn geweest. In dit onderzoek werden de patiënten gevolgd tot en met zes maanden na datum hervatting. wat voor het overgrote deel van de patiënten neerkomt op acht tot twaalf maanden na infarct. Vermeulen et al. (1981) komen in een follow-up onderzoek van vijf jaar bij 99 hartinfarctpatiënten tot nogal sombere konklusies. Na een oorspronkelijk hervattingspercentage van $65 \%$ blifkt na vijf jaar alsnog $15 \%$ definitief uitgevallen te $z i j n$.

Genoemde auteurs verzuimen echtex na te gaan wat een nomale WAO/AAW-instroom van hun onderzoeksgroep zou zijn geweest. OP grond van de GMD-statistleken kan worden berekend dat voor de leeftijaskategorie 40-55 jaar jaarlijks een instroom van circa $2.5 \%$ is te verwachten (GMD-jaarverslagen, 1978 , 1979). Wanneer we dit gegeven toepassen op het onderzoek van vermeulen, komt men al snel tot een uitval van circa $10 \%$. 
Op dit punt lijken sombere konklusies dus vooralsnog niet gerechtvaardigd. Somberheid is wel geboden wanneer men zich afvraagt wat het resultaat van het CARGO-onderzoek zou zijn, indien dit in 1982 herhald zou worden. Gezien de aanzienlijke ekonomische verslechtering sinds het onderzaek werd afgesloten (eind 1978), moet men wel aannemen dat de resultaten aanmerkelijk ongunstiger zouden uitvallen.

Het ziekteverzuim van hartinfarctpatienten die het werk hebben hervat bleek niet zeer afwijkend te zijn van landelijke cijfers. Eigenlijk ligt de bevinding dat infarctpatiënten een redelijk ziekteverzuim hebben voor de hand als men zich realiseert dat de hervatters een positieve selektie vormen uit de totale groep overlevenden: jongere leeftijd, hogere beroepen en minder komplicerende omstandigheden met betrekking tot het doorgemaakte infarct. Vroege fysieke rekonditionering, dat wil zeggen beginnend binnen twee maanden na infarct, bleek zowel een positieve invloed te hebben op het percentage dat hervat als op het percentage patienten dat geheel hervat. Het is evenwel niet uit te sluiten dat de patiënten die vroege fysieke revalidatie genoten ook het meest tot werkhervatting gemotiveerd waren. De konsistentie van het positieve effekt van vroege fysieke revalidatie op het percentage hervatters, het percentage gehele hervatters en de algemene tevredenheid van de patiënten, is in elk geval opvallend.

\subsection{Het Leidse onderzoek}

In het Leldse onderzoek, dat een gerandomiseerde opzet had, konden geen positieve effekten van revalidatie worden vastgesteld. Dit is waarschijnlijk te wijten aan twee omstandigheden: de relatief ongunstige startpositie van de revalidatiegroep, waarvan moet worden aangenomen dat die toevallig tot stand is gekomen, en de betrekkelijke late start (drie maanden na infarct) van de revalidatie. Dit laatste vraagt enige toelichting. Wanneer aangenomen wordt dat fysiek en psychisch herstel voor een belangrijk deel in de eerste maanden na infarct plaats vinden en daarna vooral sociaal herstel aan de orde komt, dan is een fysiek georiënteerd revalidatieprogramma als het ware 'uit fase' met het normale herstel. Potentiêle positieve invloeden hebben dan geen kans meer. Deze redenering bleek een zekere plausibiliteit 
te hebben in het licht van de verzamelde gegevens. Ten aanzien van de partners van de patienten bleek echter wel een licht positief effekt van de revalidatie warneembaar: in tegenstelling tot de echtgenotes uit de kontrolegroep bleken die uit de revalidatiegroep zich positiever tegenover hun man op te stellen. Dit gegeven was echter weer niet van invloed op het herstel van de man. Voor werkhervatting bleek evenwel van belang of de man de eventulele bemoeienis van de vrouw al dan niet percipieert. Mannen die de bemoeienis -al dan niet terecht- niet waarnemen, hebben een grotere kans op werkhervatting. Dit resultaat is kongruent met de bevinding van Merens-Riedstra (1981) die in een onderzoek bij langdurig arbeidsongeschikten vond dat na vier maanden arbeidsongeschiktheid, potentiële niet-hervatters zich meer op gezin en familie oriënteerden dan de potentielle hervatters.

8.3 Teoretische betekenis van de onderzoeksresultaten De onderzoeksresultaten hebben vooral betekenis voor de determinanten van werkhervatting na hartinfarct. Het CARGoonderzoek leverde een bevestiging op van de in de literatuur vermelde invloed van leeftija, beroepsniveau en ernst van de aandoening. Het Leidse onderzoek toonde aan dat, met uitzondering van leeftijd, gezondheidsperceptie-achtige variabelen interveniëren tussen deze faktoren en werkhervatting. Dit betekent dus een ondersteuning van de gezondheidsperceptie-benadering. zoals die voor hartinfarctpatiënten is beschreven (Krantz, 1980). De resultaten komen bovendien in grote lijnen overeen met die van zowel wiersma (1979) als Merens-Riedstra (1981). Aangezien door beide laatstgenoemde auteurs onderzoek is verricht op langdurig arbeidsongeschikten in verschillende diagnose-kategorieên, kan men veronderstelien dat bij langdurig zieken, gezondheidsperceptie, in casu toekomstverwachting, hervattingsprognose, gepercipieerde ernst, van cruciale betekenis is voor de verklaring van werkhervatting. Het Leidse onderzoek onderscheidt zich van de genoende onderzoeken doordat de variabelen konsekwent op een teoretisch kader, namelijk dat betreffende fysieke aktiviteiten (Weeda, 1977), zijn betrokken. Er werden aanwijzingen gevonden dat $A$-type-achtig gedrag wel eens een positieve invloed zou kunen hebben op herstel 
na hartinfarct. Dit is gebaseerd op de resultaten van de analyse van coping-strategieën, warin bleek dat kompartimentalisatie -lage neuroticisme- en hoge extraversie-scoreeen positief effekt had op werkhervatting en de tevredenheid met de gezondheid. Omdat $A / B$ typologie in dit onderzoek niet met de geêigende meetinstrumenten is benadera, blijft de rol van de 'coronary personality' in het herstel na hartinfarct grotendee ls onopgehelderd.

\subsection{Praktische betekenis van de onderzoeksresultaten}

Welke aanbevelingen zijn nu te doen ten aanzien van de revalidatie na hartinfarct? Het CARGO-onderzoek heeft het aannemelijk gemaakt dat met vroege fysieke revalidatie, zelfs in de vorm van een simpel trainingsprogramma onder leiding van de behandelend specialist met fysioterapeut, een positief effekt $\mathbb{i s}$ te bereiken op werkhervatting. Indien werkhervatting als belangrijkste suksescriterium wordt gehanteerd is de aanbeveling simpel: leg de revalidatie zo veel mogelijk in handen van de behandelend specialist, of, met andere woorden, zorg voor revalidatiefaciliteiten bij elk ziekenhuis waar een redelijk aantal hartinfarctpatiënten kan worden verwacht. Nu doet zich echter de omstandigheid voor dat werkhervatting door de neergang in de ekonomie steeds prablematischer wordt, zozeer zelfs dat het door de Europian Society of Cardiology als suksescriterium van revalidatie is afgeschaft. Echter, waar de deskundigen doende zijn werk van zijn warde te ontdoen, wil dit nog niet zeggen dat voor de patienten hetzelfde geldt. Integendee 1 , uit dit onderzoek en ook wit dat van Merens-kiedstra blijkt dat werken van beslissende betekenis is voor de tevredenheid van langdurig zieken, in casu hartinfarctpatienten. Werk is tot nog toe nu eenmal voor een groot deel van de mensen een onvervangbare bron van niet alleen inkomen, maar ook van sociale kontakten en gevoel van eigenwaarde. Zolang naast de arbeidsrol geen maatschappelijk zinvol alternatief is ontstaan, zal ook de hartrevalidatie kampen met het probleem welke andere konkrete revalidatiedoelen dan zullen gelden. Voorzover echtex door de patiënten werken als nastrevenswaardig doel wordt beschouwd, zal men hier in zijn revalidatieprogramma rekening mee moeten houden. Gezien het feit dat door hartpatiënten hervatting in eigen werk belangrijker wordt geacht dan ge- 
hele hervatting, zou kunnen worden gesuggereerd dat voor deze kategorie patiënten deeltijdarbeid in eigen werk een mogelijke oplossing kan betekenen.

Daarnaast verdient het aambeveling zoals ook al is gesuggereerd door Verkley en Voorhan (1982), de revalidatie zo veel mogelijk te individualiseren, dat wil zeggen het revalidatiedoel in overleg tussen patiënt en revalidatieteam tot stand te laten komen. Eerst is echter meer inzlicht nodig voor de indikatiestelling: ex is onvoldoende duidelijkheid welke patiënten het meest gebaat zijn bij welke revalidatievariant. Het is overigens zaak te waarschuwen voor te hoog gespannen verwachtingen. Blijkens het Leidse onderzoek geldt voor tal van faktoren, zelfs voor een groep patiënten waarin ernstige komplikaties afwezig zijn, volledig herstel in de zin van terugkeer naar de toestand van vór infarct, in het algemeen niet te worden bereikt. 


\section{Summary}

This thesis reports the results of two studies on recovery and rehabilitation in male patients after myocardial infarction (MI).

The first study is a national descriptive epidemiological survey on return to work of patients after MI conducted in 42 occupational health services.

The second one is a small-scale experimental study on the effects of a cardiac rehabilitation programme of the Leiden University Hospital.

Chapter one reviews the relevant literature on recovery and rehabilitation after MI. The psychosocial literature can be devided into three main approaches: the psychodynamic, healthperception and patient-career approach. After a discussion on the concepts of objective and subjective recovery, and rehabilitation, a review of the research findings is given on the effects of rehabilitation on physical, psychological and social recovery. It is concluded that research findings are scattered and rather inconclusive.

Chapter two deals with the problem-statements and designs of the studies under consideration. The longitudinal epidemiological study concentrates on a description of the rate of return to work, the interval MI - return to work. absenteeism after return and factors related to these outcome-measures. This study had follow-up measurements of six months after return to work and of twelve months after MI for those who did not return to work. The experimental study concentrates on the effects of a comprehensive rehabilitation programme with several objective and subjective outcome-measures. Rehabilitation took place between three and six months after MI. Follow-up measurements were scheduled at 12 and 24 months after MI.

Chapter three gives a description of the populations under study. In the epldemiological study, 42 occupational health services produced data on 888 patients. The possibility of underreporting by the occupational health officers is discussed. In the experimental study a group of 73 patients could be allocated at random to the rehabilitation and control group. However, since 22 patients dropped out, an 
analysis on the characteristics of these patients in comparison with the remaining ones $(n=51)$ was carried out. It is concluded that the internal validity of the study is not seriously threatened by the drop-outs.

Chapter four presents the main results of the epidemiological study on return to work as objective recovery. af the 888 patients 23 died within a year after MI. In the group of survivors the rate of return to work was $65 \%, 37 \%$ full-time and $28 \%$ part-time return.

Probability of return proved to be optimal in the first half year after MI as 50\% of the survivors returned to work in this period. Predictors (positive or negative) of return to work are in declining order of importance: age (-), anglna pectoris $(-)$, occupational level $(+)$, caraiac complications (-) , physical rehabilitation within two months after MI (+), and number of infarctions $(-)$. Moreover, early physical rehabilitation has a positive effekt on full-time return. occupational level $(+)$ and angina pectoris $(-)$ also play a role as predictor of full-time return and return to former work. Absenteeism in the group under 55 years was comparable with general Dutch figures. In patients of 55 years and older absenteeism is lower than the general figures.

In chapter five return to work is approached as a measure of subjective recovery. Firstly, the judgements of ocoupational health officers and patients on success of return to work is analyzed. Although both parties appear to be rather satisfied with the situation after return to work, for patients to return to their former work is more important in determining satisfaction than full-time return; while the reverse holds for the occupational health officers.

In a multiple regression analysis return to work proved to be the main determinant of 1 ife-satisfaction, also, early physical rehabilitation appeared as a positive predictor of satisfaction.

In chapter six the main results of the experimental study are presented. The outcome measures of 6,12 and 24 months after MI were: maximal exercise tolerance, degree of activity, subjective 1oad, perceived exercise tolerance, participation in household labor, leisure activities, dally use of time and optimisme about future heaith. With theexception 
of a short-term training-effect in the rehabilitation group $(n=24)$, no further differences between this group and the control-group $(n=27)$ could be found. There were, however. indications that spouses in the rehabilitation group were positively influenced by the programme. In the discussion much attention is given to the fact that on all measurements the control-group turned out to be slightly, though not significantly, better than the rehabilitation-group. This and the indications that the late start of the programme ( 3 months after MI) might have disturbed social recovery are presented as explanations for the failure of the assumed rehablitation effects to materialize.

Chapter 7 starts with an analysis on the possible interaction between return to work and rehabilitation. It is concluded that no such interaction is apparent. Analogous with the epidemiological study the factors predicting return to work are considered. It appears that compartmentalisation, based on low neuroticism and high extroversion scores, is a coping strategy with a favorable outcome on return to work. It was not possible to include coping strategy in a pathanalysis on return to work due to curvilinear relationships. The model developed includes the main variables of the epidemiological study: age, occupational level and angina pectoris, plus subjective load, perceived exercise tolerance and maximal exercise tolerance at three months after MI. It appeared that with the exception of age, health perception variables intervene between the background variables and return to work.

Chapter eight summarizes the most significant results and discusses theoretical and practical implications of the two studies. Return to work appears to have a certain value as an outcome measure for recovery and rehabilitation. This, however, is confounded by the fact that present socioeconomic circumstances exert a negative influence on return to work. More attention should be qive to the definition of additional social outcome measures after that it is possible to develop rehabilitation programmes which are tailored to individual. needs and goals. 


\section{Literatuur}

APPELS A, POOL J, LUBSEN J, DOES E van dex: Psychological prodromata of myocardial infarction.

I Psychosom Res 23: 405, 1979.

As D: Studies of time-use: problems and prospects.

Acta Sociologica $21: 125,1978$.

BAKKER C B, LEVENSON $R$ M: Determinants of angina pectoris. Psychosom Med XXIX: 621, 1967.

BERK R A, BERK S F: A simultaneous equation model for the devision of household labor.

sociol Meth \& Res $6: 431,1978$.

BISHOP $Y M M$, FIENBERG $S E$, HOLIAND $P$ W: Discrete multivariate analysis: theory and practice.

MIT Press, Cambridge, 1975.

BLOCH A, MAEDER J P, HAISSLY J C, et al.: Early mobilisation after myocardial infarction.

Am $J$ of Card $34: 152,1974$.

BLOK-van der VOORT E M: Vakantie nader bekeken.

Dissertatie Leiden, 1977.

BORG G: PSychological aspects of physical activities.

In: Fitness, Health and Work Capacity (Ed: Larson

L A), 141, MacMillan, New York, 1974.

BOUDREZ H, DE COCK N: De psycho-sociale begeleiding van hartinfarctpatienten.

'Tijdschr Geneeskd 34: $351,1978$.

BRAMMEL L Early rehabilitation of the post infarction patient.

In: Prevention and Rehabilitation in Ischemic Heart Disease (Ed: Long Ch), 159, Williams \& Wilkins, Baltimore, 1980 .

BROWN J $S$, RAWLINSON $M$ : Relinquishing the sick role following open-heart surgery.

J H1th Soc Behav 16: 12, 1975.

BROWN I $S$, RAWLINSON $M$ : The morale of patients following openheart surgery.

J HIth Soc Behav 17: 134, 1976 . 
BRUHN, J G: obtaining and interpreting psychosocial data in studies of coronary heart disease.

In: Exercise testing and exercise training in coronary heart disease (Ed: Naughton $J$ et al), 263, Academic Press, New York, 1973.

CARSON P, NEOPHYTON M, TUCKER H, SIMPSON T: Exercise programme after myocardial infarction.

Brit Med J 4: 213, 1973.

CASSEM N H, HACKETT $T$ P: Psychiatric consultation in a coronary care unit.

Ann Int Med 75: 9, 1971.

CAY E L, VETTER N, PHILIP A E, DUGARD P: PSychological status during recovery from an acute heart attack. J Psychosom Res 16: 425, 1975.

CAY E L, VETTER N, PHILIP A E, DUGARD P: Return to work after a heart attack.

J Psychosom Res 17: 231, 1973.

CLAUSEN I P: Circulatory adjustment to dynamic exercise and effect of physical training in normal subjects and in patients with coronary heart disease. Progress in Cardiov Dis XVIII: 459, 1976.

Commissie Coördinatie onderzoek Hart- en Vaatziekten van de Raad voor Gezondheidsonderzoek TNO: Een bijdrage tot het onderzoeksbeleid ten aanzien van hart-en vaatziekten, TNO/CBS, 's-Gravenhage, 1980.

CROOG $S \mathrm{H}$, LEVINE $S$, LURIE $\mathrm{Z}$ : The heart patient and the recovery process.

Soc Sci \& Med 2: 111, 1968.

CROOG $S H$, LEVINE $S$ : The heart patient recovers: social and psychological Factors. Human Sciences Press, New York, 1977.

DAVIS F: Passage through crisis. Bobbs Merill, Indianapolis, 1966.

DEBUSK R F: Early Exercise Testing after myocardial infarction. In: Exercise and the heart (Ed: Wenger $\mathrm{N} \mathrm{K}$ ), 133, F.A. Davis Company, 1978. 
DEKKER J B, SCHNEPPER $F$ : Hard tegen hart. Ned Tijdschr Fysioth 9: 245, 1973.

DIEDERIKS I P M: Evaluatie van poliklinische hartrevalidatie. NIPG/TNO, Leiden, 1972.

DIEDERIKS J P M, WEEDA H W H: Perceived exercise tolerance: an evaluation of a short questionnaire for cardiac patients (abstr.). Cardiology 62: 122, 1977.

DIEDERIKS J P M: Reintegratie in het bedrijf van myocardinfarctpatiënten.

CARGO/TNO, 's-Gravenhage, 1980.

DIEDERIKS J P M: Werkhervatting na myocardinfarct. Onderzoek bij 42 bedrijfsgeneeskundige diensten. Hart Bulletin 12: 8, 1981 .

DOEHRMAN S R: Psycho-social aspects of recovery from coronary heart disease: a review. Soc Sci \& Med 11: 199, 1977.

DOES $\mathrm{E}$ van der, LUBSEN $\mathrm{J}$ : Acute coronary events in general practice, the IMIR-study. Dissertatie Rotterdam, 1978.

ERDMAN R A M: Evaluatie CAPRI-hartrevalidatieprogramma: psychologische aspekten. Hart Bulletin 10: 13, 1979.

EVERITT B S: The analysis of contingency tables. Chapman and Hill, London, 1977.

FINLAYSON A, MCEWEN $J$ : Coronary Heart Disease and Patterns of living. Croom Helm, London, 1977.

GARRITY Th $\mathrm{F}$ : Social involvement and activeness as predictors of moral six months after first myocardial infarction. Soc Sci \& Med 7: 199, 1973a.

GARRITY Th F: Vocational adjustment after first myocardial infarction; comparative assessment of several variables suggested in the literature. Soc Sci \& Med 7: 705, 1973b. 
GARRITY Th F: Morbidity, mortality and rehabilitation.

In: Psychological aspects of myocardial infarction and coronary care (Ed: Doyle Gentry W, williams R B), 124, Mosby, Saint Louis, 1975.

GARRITY Th F, SOMERS G, MARX M B: Factors influencing selfassessment of health.

Soc Sc1 \& Med 12: 77, 1978.

GELFLAND D: Experience at the cardiac work classification unit of the heart association of southeastern Pensylvania.

In: Work and the heart (Ed: Rosenbaum F F, Belknap E L), 322, Hoeber, New York, 1959.

Gemeenschappelijke Medische Dienst: Jaarverslag 1976. GMD, Amsterdam, 1977.

Gemeenschappelijke Medische Dienst: Jaarvers 1 ag 1978. GMD, Amsterdam, 1979.

Gemeenschappe1ijke Medische Dienst: Jaarverslag 1979. GMD, Amsterdam, 1980.

GOFFMAN E: Asylums; Essays on the social situation of mental patients and other inmates. Doubleday, New York, 1961.

GOODE W J: A theory of role strain. Am Soc Rev 25: 483, 1960.

GRODEN B M, BROWN R I F: Differential psychological effects of early and late mobilisation after myocardial infarction. Scand J Rehab Med 2-3: $60,1970$.

HACKETT Th P, CASSEM N H: PSYchological adaptation to convalescence in myocardial infarction patients. In: Exercise testing and exercise training in coronary heart disease (Ed: Naughton $J$ et al), 253, Academic Press, New York, 1973.

HACKETT Th P, CASSEM N H: Development of a quantitative rating scale to assess denial. J Psychosom Res 18: 93, 1974.

HACKETT Th P, CASSEM N H: PSychologic aspects of rehabilitation after myocardial infarction.

In: Rehabilitation of the coronary patient (Ed: wenger $\mathrm{N} \mathrm{K}$, Hellerstein $\mathrm{H} \mathrm{Kl}, 243$, Wiley, New York, 1978. 
HELLERSTEIN $H \mathrm{~K}$, HORSTEIN $T \mathrm{R}$ : Assessing and preparing the patient for return to a meaningful and productive life.

J Rehab 32: 48, 1966.

IBRAHIM M A, FELDMAN J G, SULTZ H A et al: Management after myocardial infarction: a controlled trial of the effekt of group psychotherapy. Int J Psychiat Med 5: 253, 1974.

IDELSON $R K$, CROOG $S H$, LEVINE $S$ : Changes in self-concept during the year after a first heart attack, a natural history approach. Am Arch Rehab Ther 22: 10, 1974.

JANIS I L: Stress and frustration. Harcourt Brace, New York, 1971.

JENKINS $C D$, ROSENMAN $R H$, ZYZANSKI $S \mathrm{~J}$ : Prediction of clinical coronary heart disease by a test for the coronary-prone behavior pattern. N Engl J Med 290: 1271, 1974.

JOHNSON R: The cardiac environment.

In: Psychological approach to the rehabilitation of coronary patients (Ed: Stocksmeier U), 62, Springer, Berlin, 1976.

JOSTEN J G J E: Emotional adaption of cardiac patients. Scand J Rehab Med 2-3: 49, 1970.

Josten J G J E: Psycho-sociale achtergrond, aandoening en werkhervatting.

In: Behoefte en revalidatiefaciliteiten voor hartpatiënten (Ed: Bonjer $\mathrm{FH}$ et $\mathrm{al}$ ), 30, GMD/NIPG, Amsterdam, 1973.

JOSTEN J G J E: Subjectieve belasting door lichamelijke aktiviteiten. NIPG/TNO, Leiden, 1973.

JURS S G, GLASS G V: The effect of experimental mortality on the internal and external validity of the randomized comparative experiment. J Exp Educ 40: 62, 1971. 
KALLIO V, HF̈MÄLÄINEN H, HAKKILA J, LUURILA O J: Reduction in sudden deaths by a multifactorial interventive programme after acute myocardial infarction. Lancet II: $1091,1979$.

KAVANAGH $T$, SHEPHARD $R \mathrm{~J}$ : The effects of continued training on the aging proces.

Ann N Y Acad Sc1 301:656, 1977.

KELLERMAN J J, KARIV I: Rehabilitation of coronary patients.

Segal Press, Tel Aviv, 1968.

KELLERMAN J J: Rehabilitation of patients with coronary heart disease.

In: Exercise and heart disease (Ed: Sonnenblick

E H, Lesch M), 183, Grune \& Stratton, New York, 1977.

KENTALA E: Physical fitness and feasability of physical rehabilitation after myocardial infarction in men of working age.

Thesis, Helsinki, 1972.

KERSKY B, GOLDWATER L J: Occupational potentialities of cardiac patients.

Am Heart J 27: 623, 1944.

KJØLLER E: Resumption of work after acute myocardial infarction. Acta Med Scand 199: 379, 1976.

KLEIN R F, DEAN A et al: The physician and postmyocardial infarction invalidism. JAMA 194: 123, 1965.

KNULST W P: Een week tijd. Rapport van een onderzoek naar de tijdsbesteding van de Nederlandse bevolking in oktober 1975.

SCP Cahier 10, Staatsdrukkerij, 's-Gravenhage, 1977.

KRANT'Z D S: Cognitive processes and recovery from heart attack: a review and theoretical analysis.

J Hum stress 6: 27, 1980.

KUHNS $K$, NAZERIAN $I$, SUERMANN $T$ : Infaxkt-Rehabilitation unter Sozialmedizinischem Aspekt.

ASP 2: 26, 1978 .

KUSHNIR $B$, FOX $K M$, TOMLINSON $J \mathrm{~W}$ et al: The influence of psychological factors and an early hospital follow-up on return to work after first myocardial infarction. Scand J Rehab Med 7: 158, 1975. 
LANGE ANDERSSEN $K$ (Ed): Habitual physical activity and Health.

WHO Regional Publications no. 6, Copenhagen, 1978.

IEIGH H, HOFEN M A et al: A psychological comparison of patients in 'open' and 'closed' coronary care units. J Psychosom Res 16: 44, 1972.

LEMERT E M: Human deviance, social problems and social control.

Prentice-Hall, Englewood Cliffs, 1967.

LIE K I, ROELS-van IJSSELDIJK Y C, VERMEULEN A, WELLENS H $J \mathrm{~J}$ : Een prospectieve studie van de 1 -jaars overleving en van de werkhervatting na het hartinfarct. Ned Tijdschr Geneesk 119: 1890, 1975.

MACDONALD K I: Path analysis.

In: The analysis of survey data; volume 2 : model fitting (Ed: O'Muircheartaigh C A, Payne C), 81, wiley, Chichester, 1979.

MADDOX GI, EISDORFER C: Some correlates of activity and morale among the elderly. Soc Forces 40: $254,1962$.

MADDOX $G$ L: Activity and morale: a longitudinal study of selected elderly subjects.

Soc Forces 42: 195: 1963.

MALLAGHAN M, PEMBERTON J: Some behavioural changes in 493 patients after an acute myocardial infarction. Brit J Prev Soc Med 31: 86, 1977.

MATZDORFF F* Sozialmedizinische Aspekte der Frürehabilitation nach Herzinfarkt. ASP $2: 30,1978$.

MAYOU R, WILIIAMSON b, FOSTER A: Outcome two months after myocardial infarction.

J Psychosom Res $22: 439,1978 \mathrm{a}$ :

MAYOU R, FOSTER A, WILLIAMSON B: PSycho-social adjustment in patients one year after myocardial infarction. $J$ Psychosom Res 22: 447,1978 b. 
MAYOU R, FOSTER A, WILLIAMSON B: The psychological and social effects of myocardial infarction on wives. Brit Med J 1, 699, 1978C.

MCPHERSON B D, PAIVIO A, YUHASZ M S et al: Psychological effects of an exercise program for post-infarct and normal adult men. J Sports Med 7: 95, 1967.

MECHANIC C: Discussion of research programs on relations between stressful life events and episodes of physical illness.

In: Stressful life event (Ed: Dohrenwend B S, Dohrenwend B P), 88, Wiley, New York, 1974.

MERENS-RIEDSTRA H S: Leven zonder werk; een socilaal-wetenschappelijk onderzoek naar arbeidsongeschiktheid. Dissertatie, Mastricht, 1981.

MONTEIRO L A: Cardiac patient rehabilitation; social aspects of recovery. Springer, New York, 1979.

NAUGHTON J, BRUHN J G, LATEGOLA M T: Effects on physical training on physiologic and behavioral characteristics of cardiac patients. Arch Phys Med 49: 131, 1968.

NAUGHTON J: The national exercis and heart disease project: Development, recruitment and implementation. In: Exercise and the heart (Ed: Wenger, N K), 205, E A Davis Company, Philadelphia, 1978.

NIEUWENHUIZEN C L C van: Revalidatie van hartpatiënten. In: Advies inzake de bestrijding van hart- en vaatziekten. Min. van Volksgez en Milieuhyg, 's-Gravenkage, 1971 .

OOST $\mathrm{P}$ van, DEPOORTER A M: Post-myocardial Infarction psychological problems: a behavioral approach. In: Psychological approach to the rehabilitation of coronary patients (Ed: Stocksmeier U), 71, Springer, Berlin, 1976 .

OOSTENBRINK A A: Onderzoek naar verzekeringsgeneeskundige prognose van hartinfarct en angina pectoris. Tijdschr Soc Geneeskd 49: 894, 1971. 
PALMORE $E$, LUIKART $C$ : Health and social factors related to life satisfaction.

J Hith Soc Beh 13: 68, 1972.

PARKER D L, HODGE J R: Delirium in a coronary care unit. JAMA 201: 132, 1967.

PARSONS T: The social system.

Free Press, Glencoe, 1951.

PHILIPSEN H: Afwezigheid wegens ziekte.

Wolters- Noordhoff, Groningen, 1969.

POZEN M W, STECKMILLER J A, HARRIS $W$ et al: A nurse rehabi-

litator's impact on patients with myocardial

infarction.

Med Care XV: 830, 1977.

PYFER $H R$, MEAD W F, FREDERICK $R C$, DOUNE B L: Exercise rehabilitation in coronary heart disease: community group programs.

Arch Phys Med 57: 335, 1976.

RECHNITZER P A, YUHASZ M. S, PAIVIO A et al: Effects of a 24-weeks exercise programme on normal adults and patients with previous myocardial infarction. Brit Med J 1: 734, 1967.

Revalidatiecommissie van de Nederlandse Hartstichting: Revalidatie van hartpatiënten. NHS, 's-Gravenhage, 1977.

ROSEN J L, BIBRING G L: PSychological reactions of hospitalized male patients to a heart attack. Psychosom Med 28: 808, 1966.

ROTH J A: Timetables; structuring the passage of time in hospital treatment and other careers.

Bobbs-Merrill, Indianapolis, 1963.

Royal College of Physicians of London and the British Cardiac Society: Cardiac Rehabilitation 1975.

J Roy Coll Phycns London 9: 286, 1975.

SAFILIOS-ROTHSCHILD C: The sociology and social psychology of disability and rehabilitation.

Random House, New York, 1970. 
SALONEN J $T$, PUSKA P: A community programme for rehabilitation and secondary prevention for patients with acute myocardial infarction.

Scand J Rehab Med 12: 33, 1980.

SCHELLING A: Evaluatie CAPRI-hartrevalidatieprogramma. Inspanningsfysiologische en echocardiologische aspekten. Hart Bulletin 10: 7, 1979.

SHEPHARD R $\mathrm{J}$ : Current status and prospects for post coronary exercise multicentre studies. Med Sci Sports 11: 383, 1979.

SHEPHARD R J: Ischaemic Heart Disease and Exercise. Croom Helm, London, 1981.

SIMON A B, FEINLEIB M, THOMPSON H K: Components of delay in the pre-hospital phase of acute myocardial infarction. Cardlology 30: 476, 1972.

SIVARAJAN E S, BRUCE R A, ALMES $M J$ et al: In-hospital exercise after myocardial infarction does not improve treadmill performance.

N Eng J Med 305: 357, 1981.

SKELTON M, DOMINIAN J: PSYchological stress in wives of patients with myocardial infarction. Brit Med J 2: 101, 1973.

SLUIJS $H$ van der, DIRKEN J $M$ : Dagelijks energieverbruik van de Nederlandse industrie-arbeider. Wolters-Noordhoff, Groningen, 1970.

SLUIJS $H$ van der: A standard analysis of daily energy expenditure and patterns of activity.

In: Functional age of industrial workers (Ed:

Dirken I M), 97, Wolters-Noordhoff, Groningen, 1972.

SLUIJS $H$ van der, DIEDERIKS J P M, SCHOBRE $M G$, WEEDA H $W \mathrm{H}$ : Lichamelijke aktiviteiten na hartinfarct; relaties met cardiale, inspanningsfysiologische, psychologische en sociale faktoren. Hart Bulletin 10: 24, 1979 .

SOETERS $\mathrm{J}$ : Afwezigheid wegens ziekte in het herstructureringsgebied zuid-Limburg.

Rijksuniversiteit Limburg, Maastricht, 1980. 
SOLOFF P H, BARTEL A G: Effects of denial on mood and performance in cardiovascular rehabilitation. J Chron Dis 32: 303, 1979.

Staff of the Work Classification Unit, Bellevue Hospital New York: An occupational analysis of 580 cardiac clinic patients. Circulation III: $289,1951$.

STERN M J, PASCALE I, MCLOONE J B: Psychosocial adaption following an acute myocardial infarction. J Chron Dis 29: $513,1976$.

STERN M J, PASCALE L, ACKERMAN A: Life adjustment in postmyocardial infarction. Arch Intern Med 137: 1680, 1977.

STREIB G: Morale of the retired. Soc Problems 3: 270, 1956.

SUCHMAN E A: Stages of illness and medical care. J Hlth hum Beh. $6: 114,1965$.

TRISTANI F E: National intervention trials and their descendants.

In: Prevention and rehabilitation in Ischemic Heart Disease (Ed: Long Ch), 367, Williams \& Wilkins, Baltilmore, 1980 .

VERKLEIJ H, VOORHAM A: Hartrevalidatie in ontwikkeling. Gezondheid en Samenleving 3: 24, 1982.

VERMEULEN A, HEIJBOER C, LIE K I: Een vergelijkend onderzoek naar de invloed van een revalidatieprogramma bij hartinfarctpatiënten.

Ned Tijdschr Geneeskd 122: 1737, 1978.

VERMEULEN A, LIE K I, DURRER D: De invloed van revalidatie na een eerste hartinfarct bij mannen van middelbare leeftijd op de werkhervatting, na 3-5 jaar. Ned Tijdschr Geneeskd 125: 1921, 1981.

VERSTAPPEN H M, POL Y M Y van der, NIVELLE H M $F$ de: Enkele ervaringen bij revalidatle van patiënten met een myocardinfarct. Ned Tijdschr Geneeskd 118:716, 1974 .

VISSER J F: Hartrevalidatie. Tijdschr soc Geneeskd 55: 713, 1977. 
WEEDA H W H Arterial pressures during exercise in normals, in patients with aortic coarctation and in patients with myocardial infarction.

Ma1 Cardiov $x: 1,1969$.

WEEDA $\mathbb{H} \mathrm{H}$ : Inspanning en hartziekten.

Geneeskunde en sport 4: 58,1971 .

WEEDA H W H, SLUIJS H van der, SCHOBRE M H, BINK B: Tabe1len, formules voor de berekening van de maximale zuurstofopname, de Watts, het basalimetabolisme en het energieverbruik voor mannen.

Academisch Ziekenhuis Leiden, 1975.

WEEDA H $W$ H: The function of a model and an operational system.

In: Critical evaluation of cardiac rehabilitation (Ed: Kellerman J J, Denolin H), 90, S.Karger, Basel, 1977.

WEEDA H W H: Revalidatie van hartpatiënten.

In: Nederlands leerboek der Cardiologie (Ed: Dunning A J, Meijler F L, Verheugt A P M), 442, Bohm, Scheltema \&olkema, Utrecht, 1978.

WEEDA HW H, VISSER J F: Revalidatie van hartpatienten anno 1981 .

Hart Bulletin, 12:3, 1981 .

WEINBLATT E, SHAPTRO $S$, FRANK Ch $W$, SAGER R V: Return to work and work status following first myocardial infarction. An I Publ H1th $56: 169,1966$.

WEINSTOCK $M$, HAFT $J J$ : The effect of illness on employment opportunities.

Arch Envixon HIth 29: 79, 1974 .

WENGER N K: Cardiac rehabilitation: the United Kingdom and the United States.

Ann Int Med 84: 215, 1976.

WENGER N K: Critical evaluation of cardiac rehabilitation. Chest $71: 317,1977$.

WENGER N K: Research related to rehabilitation. Circulation $60: 1636,1979$. 
WHO Ischaemic Heart Disease Registers. Report of the Fifth Working Group.

WHO, Copenhagen, 1971.

WIERSMA D: Psychosociale 'stress" en langdurige arbeidsongeschiktheid.

Dissertatie, Groningen, 1979.

WILHELMSEN L, SANNE H, ELMFELDT D et al: A controlled trial of physical training after myocardial infarction. Prev. Med. 4: 491, 1975.

WILHELMSSON C,VEDIN A, ELMFELDT D et al: Symptoms, disablement and treatment during two years after myocardial infarction.

Scand J Rehab Med 8: 85, 1976.

WILDE G J $S$ : Neurotische labiliteit gemeten volgens de vragenlijstmethode. Van Rossen, Amsterdam, 1970.

WILLIAMS $D O$, AMSTERDAM E A, DEMARIA $A \mathrm{~N}$ et al: Physical activity in the rehabilitation of patients following myocardial infarction. Basis of early ambulation.

Heart and Lung, 5: 317, 1976.

WINER B J: Statistical principles in experimental design. MCGraw Hill, Tokyo, 1971.

WIPPLER R: Sociale determinanten van het vrijetijdsgedrag. Dissertatie, Groningen, 1968.

YOUNG M, WILLMOTT P: The Symmetrical Family. Penguin Books, Harmondsworth, 1975. 
- 


\section{Bijlage 1:}

Overzicht variabelen in het Leidse onderzoek

Kontrolevariabelen

leeftijd

beroepsniveau

$$
-1 \text { aag }
$$

angina pectoris

$$
\begin{aligned}
& \text { - - kleine zelfstandige } \\
& \text {-hoog }
\end{aligned} \begin{aligned}
& \text { random } \\
& \text { procedure }
\end{aligned}
$$

Medische voorgeschiedenis

-hartinfarct

-angina pectoris

-beroerte

-hoge bloeddruk

- suikerziekte

-hypercholesterolemie

-antistolling

Huidig infarct

komplikaties CCU

-decompensatie cordis

-shock

-thrombo-embolie

-hartstilstand

-recidief infarct

-ernstige aritmie

- langdurige AP

grootte van het infarct: groot CPK $>900$ of $\mathrm{LDH}>1000 \mathrm{u} / 1$ borderline $250<\mathrm{CPK}<900$ of $350<\mathrm{LDH}<1000$ klein $\mathrm{CPK}<250$ en $\mathrm{LDH}<350$

thoraxfoto:

hart te groot: hart - thorax ratio $>50 \%$

medikatie

-digitalis

-diuretica

-B-blokker

-antiaritmica

- antihypertensiva

-anticoagulentia

Psychologische kenmerken neuroticisme extraversie 
Sociale kenmerken burgerlijke status arbeidssituatie vóór infarct

Criteriumvariabelen

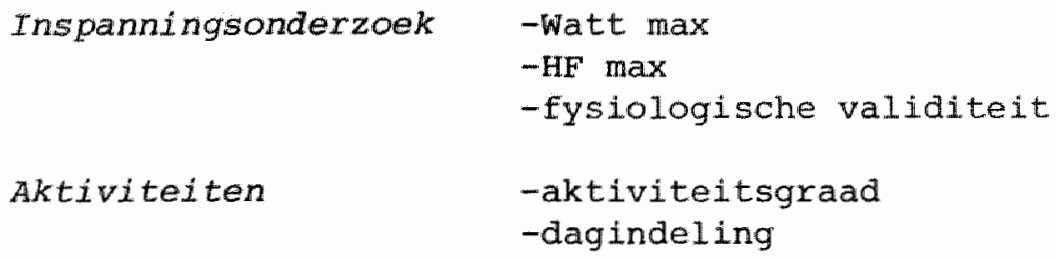

Aktiviteiten

-aktiviteitsgraad

-dagindeling

Psychologische kenmerken-subjektieve belasting

-gepercipieerde inspanningstolerantie (man/vrouw)

-toekomstverwachting werk, gezondheid

Sociale kenmerken

-aktieve vrijetijdsbesteding

-participatie huishouden

-perceptie man aanmoediging/afkeuxing vrouw

-gegeven aanmoediging/afkeuring vrouw 
Bijlage 2:

Kontra-indikaties voor poliklinische hartrevalidatie in Katwijk:

-periode na hartinfarct korter dan 6 weken

- decompensatio cordis

-aneurysma cordis, ventrikel septum defect en mitralis insufficientie t.g.v. hartinfarct

-ritme-stoornissen van ventriculaire aard, en geleidingsstoornissen (zoals tweede graad $a-V$ blok)

-arteriële hypertensie

-complicerende andere hartaandoeningen (mitraal stenose, aorta stenos, cardio myopathy, myocarditis)

-ernstige angina pectoris, die al klachten geeft bij A.D.L. en lopen in eigen tempo

-recente toeneming van angineuze klachten

-stoornissen in de longfunktie en afwijkingen in het lokomotore apparaat die lopen en fietsen storen.

-psychiatrisch vastgestelde aandoeningen. 
B1jlage 3:

Kenmerken CCU-populatie, aangeboden, ingedeeld en ten onrechte niet ingedeelde groep (Leids onderzoek).

\begin{tabular}{|c|c|c|c|c|}
\hline & $\begin{array}{c}\mathrm{CCU} \\
(\mathrm{n}=234)\end{array}$ & $\begin{array}{l}\text { aangeboden } \\
(n=146)\end{array}$ & $\begin{array}{c}\text { ingedee } 1 d \\
(n=73)\end{array}$ & $\begin{array}{l}\text { ten onrechte } \\
\text { niet in onderz. } \\
\qquad(\mathrm{n}=38)\end{array}$ \\
\hline leeftija: & $\begin{array}{l}52.9 \\
(7.6)\end{array}$ & $\begin{array}{l}53.0 \\
(7.3)\end{array}$ & $\begin{array}{l}51.7 \\
(7.6)\end{array}$ & $\begin{array}{l}50.8 \\
(6.3)\end{array}$ \\
\hline beroep: $\begin{array}{r}\text { laag } \\
\text { zelfstandig } \\
\text { hoog }\end{array}$ & $\begin{array}{l}44 \% \\
19 \% \\
37 \%\end{array}$ & $\begin{array}{l}498 \\
218 \\
298\end{array}$ & $\begin{array}{l}51 \% \\
18 \% \\
32 \%\end{array}$ & $\begin{array}{r}18 \% \\
5 \% \\
76 \%\end{array}$ \\
\hline $\begin{array}{r}\text { werk vóor MI : ja } \\
\text { nee } \\
\text { onbekend }\end{array}$ & $\begin{array}{r}79 \% \\
16 \% \\
5 \%\end{array}$ & $\begin{array}{r}79 \% \\
158 \\
5 \%\end{array}$ & $\begin{array}{c}92 \% \\
8 \% \\
0\end{array}$ & $\begin{array}{c}92 \% \\
8 \% \\
0\end{array}$ \\
\hline $\begin{array}{r}\text { grootte infarct: } \\
\text { korder } 1 \text { ine } \\
\text { groot } \\
\text { onbekend }\end{array}$ & $\begin{array}{l}22 \% \\
51 \\
17 \\
10\end{array}$ & $\begin{array}{l}23 \% \\
49 \% \\
19 \% \\
9 \%\end{array}$ & $\begin{array}{l}298 \\
528 \\
10 \% \\
108\end{array}$ & $\begin{array}{l}29 \% \\
61 \% \\
5 \% \\
5 \%\end{array}$ \\
\hline $\begin{array}{r}\text { recidief infarct: } \\
\text { nee } \\
\text { onbekend }\end{array}$ & $\begin{array}{r}16 \\
78 \\
6\end{array}$ & $\begin{array}{r}14 \% \\
82 \% \\
4 \%\end{array}$ & $\begin{array}{c}8 \% \\
928 \\
0\end{array}$ & $\begin{array}{c}58 \\
958 \\
0\end{array}$ \\
\hline
\end{tabular}


Bijlage 4:

Variantie-analyses onderzoeksgroep/uitval (Leidse onderzoek) 1. Watt max drie maanden na MI

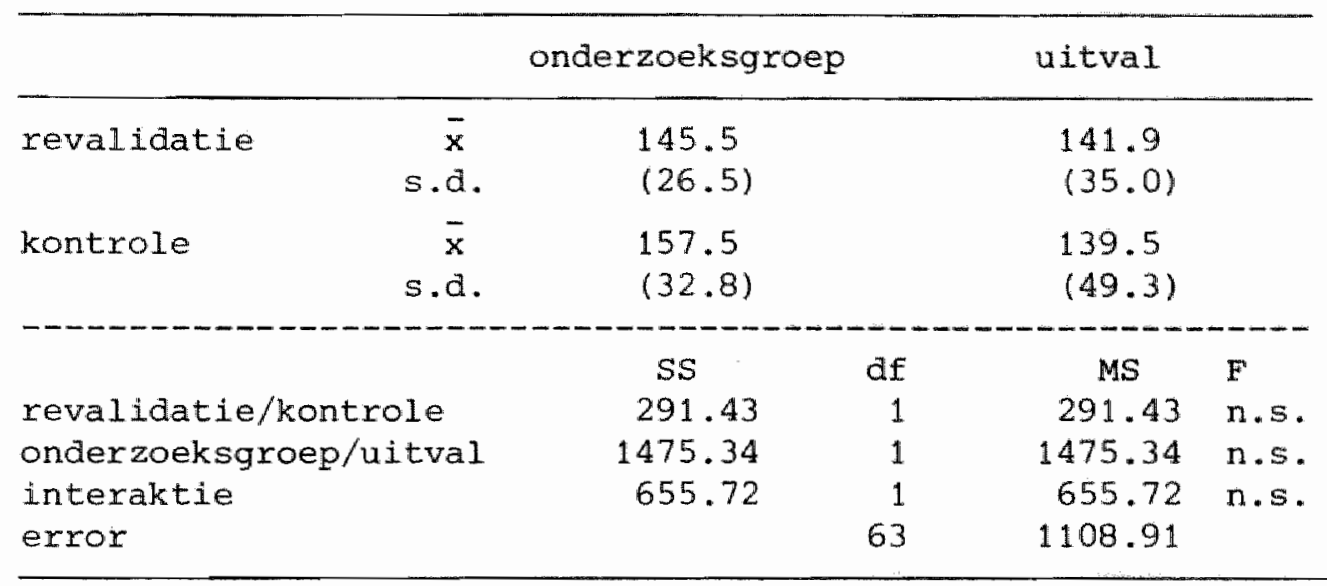

2. Aktiviteitsgraad vóor infarct

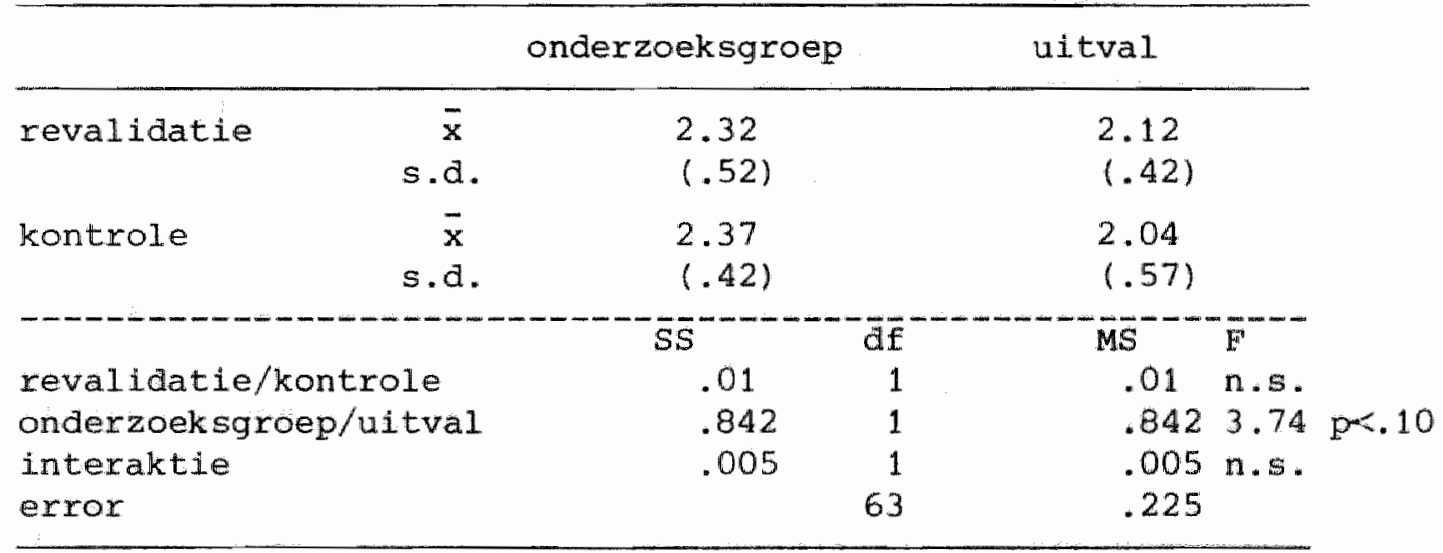


3. Subjektieve belasting drie maanden na MI

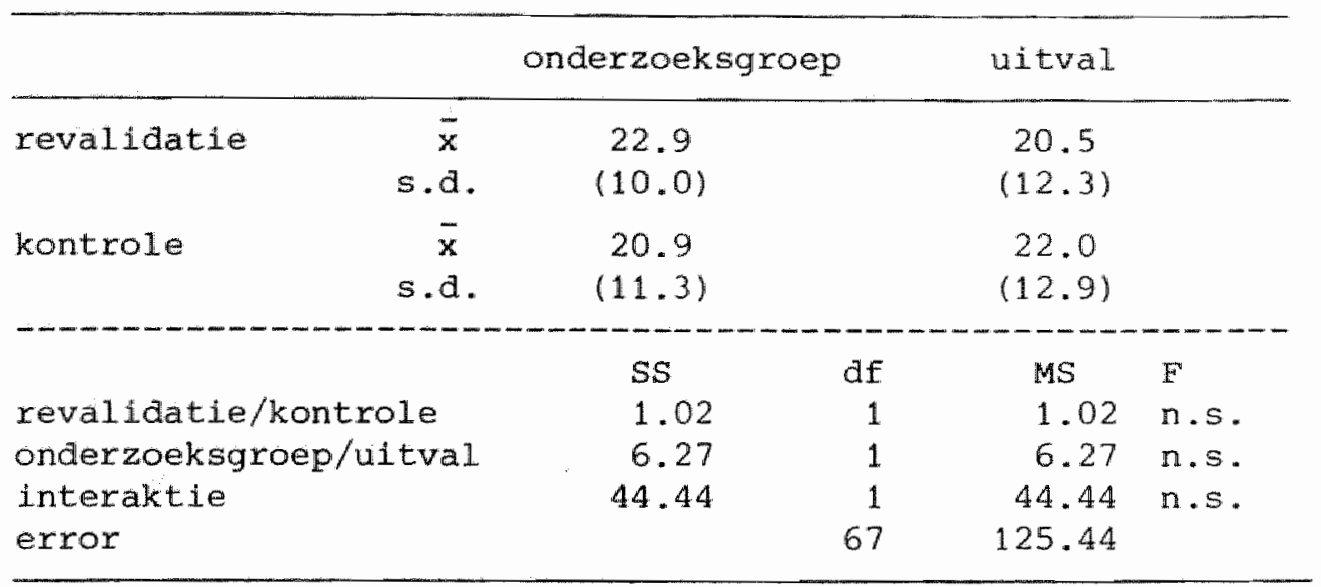

4. Gepercipieerde inspanningstolerantie ( $\left.\mathrm{PET}_{3}\right)$

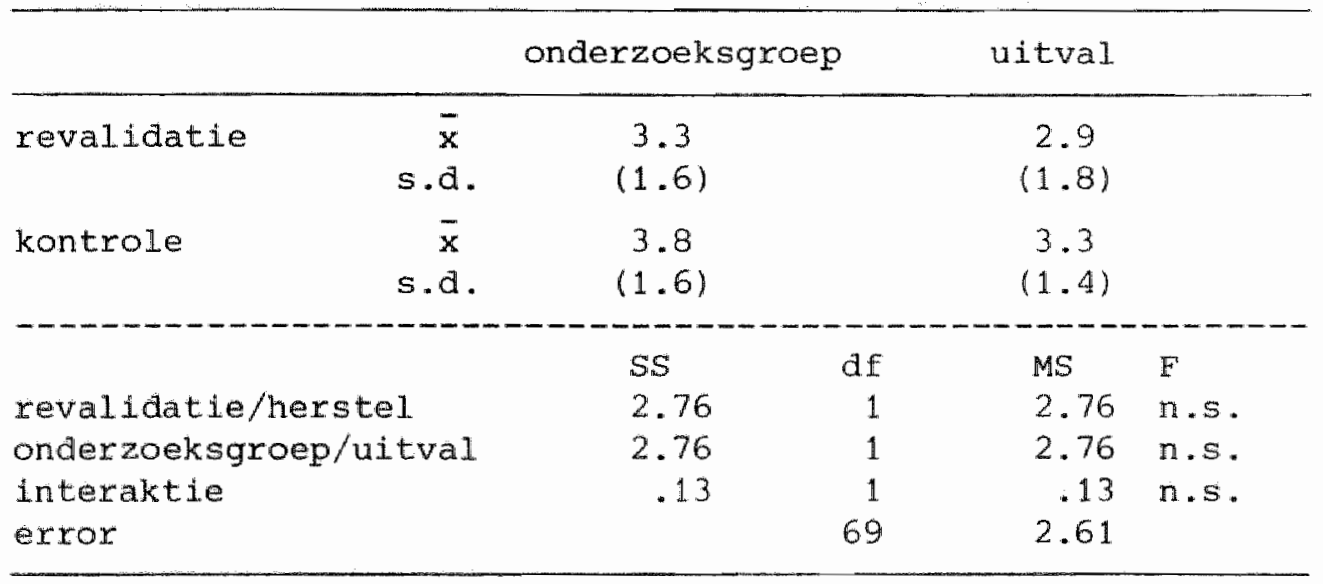


5. Testattitude drie maanden na MI (T-score)

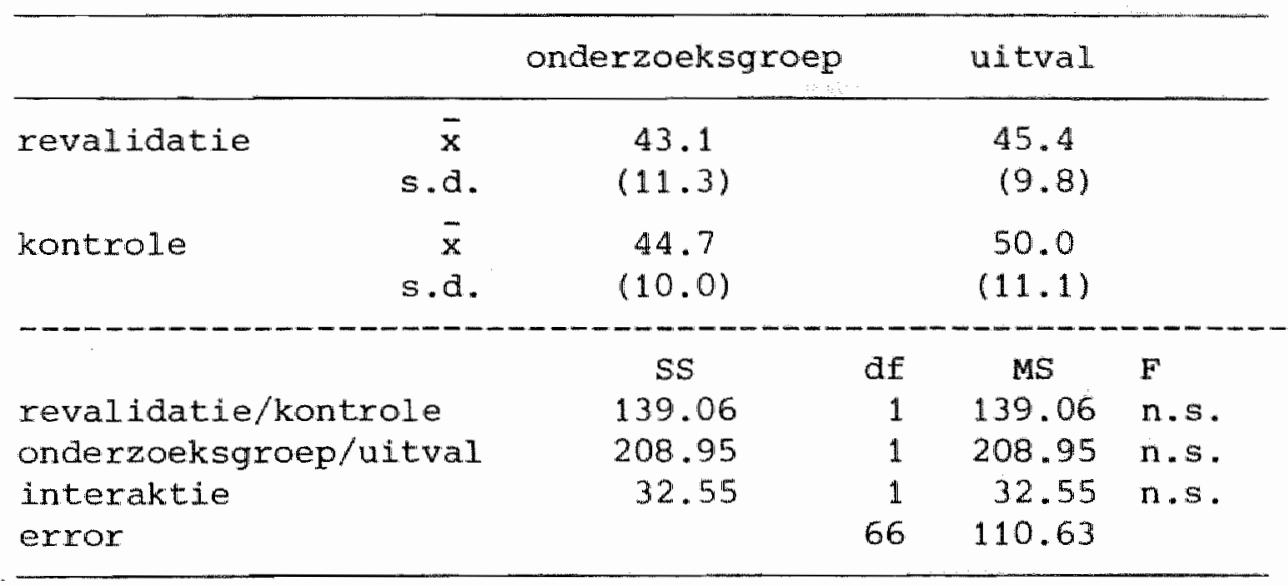

6. Beroepsniveau

\begin{tabular}{|c|c|c|c|c|}
\hline & \multicolumn{2}{|c|}{ onderzoeksgroep } & \multicolumn{2}{|c|}{ uitval } \\
\hline & rev. & kontr. & rev. & kontr. \\
\hline laag & 12 & 13 & 5 & 7 \\
\hline zelfstandig & 6 & 6 & 1 & 0 \\
\hline hoog & 6 & 8 & 6 & 3 \\
\hline \multicolumn{5}{|c|}{$X_{L}^{2}=7.97, d f=7, n .5}$. \\
\hline \multicolumn{5}{|c|}{ 7. Angina pectoris vóór i } \\
\hline . & \multicolumn{2}{|c|}{ onderzoeksgroep } & \multicolumn{2}{|c|}{ uitval } \\
\hline & rev. & kontr. & rev. & kontr. \\
\hline+ & 7 & 3 & 3 & 1 \\
\hline- & 17 & 24 & 9 & 9 \\
\hline
\end{tabular}


8. Angina pectoris één maand na MI

\begin{tabular}{|c|c|c|c|c|}
\hline & \multicolumn{2}{|c|}{ onderzoeksgroep } & \multicolumn{2}{|c|}{ uitual } \\
\hline & rev. & kontr. & rev. & kontr. \\
\hline+ & 5 & 6 & 4 & 3 \\
\hline- & 19 & 21 & 8 & 7 \\
\hline
\end{tabular}

9. Hypertensie vór infarct

\begin{tabular}{ccccc}
\hline & \multicolumn{2}{c}{ onderzoeksgroep } & \multicolumn{2}{c}{ uitval } \\
\hline & rev. & kontr. & rev. kontr. \\
+ & 2 & 6 & 3 & 1 \\
\hline & 22 & 21 & 9 & 9 \\
\hline
\end{tabular}

$x_{\mathrm{L}}^{2}=3.21, \mathrm{df}=4$, n.s.

10. Grootte van het infarct

\section{uitval}

onderzoeksgroep

rev. kontr. rev. kontr.

groot

borderilne

kein

onbekend

1
14
7
2

1

16

8

2

$\begin{array}{ll}3 & 1 \\ 3 & 4 \\ 4 & 2 \\ 2 & 3\end{array}$


11. Komplikaties ccu

\begin{tabular}{|c|c|c|c|c|}
\hline & \multicolumn{2}{|c|}{ onderzoeksgroep } & \multicolumn{2}{|c|}{ uitval } \\
\hline & rev. & kontr. & rev. & kontr. \\
\hline H & 10 & 14 & 5 & 2 \\
\hline- & 14 & 13 & 7 & 8 \\
\hline \multicolumn{5}{|c|}{$x_{L}^{2}=3.56$, df $=4$, n.s. } \\
\hline \multicolumn{5}{|c|}{ 12. B-blokkers bij ontslag } \\
\hline & \multicolumn{2}{|c|}{ onderzoeksgroep } & \multicolumn{2}{|c|}{ uitval } \\
\hline & rev. & kontr. & rev. & kontr. \\
\hline+ & 3 & 2 & 2 & 2 \\
\hline- & 21 & 25 & 10 & 8 \\
\hline
\end{tabular}

13. Anti-aritmica bij ontslag

\begin{tabular}{lcccc}
\hline & \multicolumn{2}{c}{ onderzoeksgroep } & uitval \\
\hline & rev. & kontr. & rev. kontr. \\
+ & 5 & 10 & 5 & 2 \\
\hline$X_{L}^{2}=3.23$, df $=4$, n.s. & 19 & 17 & 7 & 8 \\
& & & \\
\end{tabular}


indage $5:$

Revalidatie- en vergelijkngugrop (Leidse onderzoek)

\begin{tabular}{|c|c|c|}
\hline & $\begin{array}{c}\text { revalidatie } \\
(n=24)\end{array}$ & $\begin{array}{c}\text { Werge } 1\} \text { kingsgroep } \\
(n=24)\end{array}$ \\
\hline $\begin{array}{r}\text { sefted. } \\
\text { s.d. } \\
\operatorname{man}-\max .\end{array}$ & $\begin{array}{l}52.2 \\
(6.6) \\
42-62\end{array}$ & $\begin{array}{l}52.0 \\
(6.9) \\
36-60\end{array}$ \\
\hline $\begin{aligned} \text { bergep: } & \text { lag } \\
& \text { zelifstandig } \\
& \text { hoog }\end{aligned}$ & $\begin{array}{r}12 \\
6 \\
6\end{array}$ & $\begin{array}{r}12 \\
5 \\
7\end{array}$ \\
\hline AP 3 mnd: : & $\begin{array}{r}7 \\
17\end{array}$ & $\begin{array}{r}5 \\
19\end{array}$ \\
\hline reciadeg infarct: & $\begin{array}{r}4 \\
20\end{array}$ & $\begin{array}{r}0 \\
24\end{array}$ \\
\hline B-blokkexs 3 mnd. + & $\begin{array}{r}7 \\
17\end{array}$ & $\begin{array}{r}3 \\
21\end{array}$ \\
\hline
\end{tabular}


Bijlag 6: Frekwentieverdeling CARGo-onderzoek

I

\begin{tabular}{|c|c|c|c|c|}
\hline & \multicolumn{2}{|c|}{$A P$} & \multirow{2}{*}{$\frac{\text { recidief }}{n}$} & \multirow{2}{*}{$\frac{\text { infarct }}{8}$} \\
\hline & $n$ & 多 & & \\
\hline+ & 287 & 44 & 60 & 9 \\
\hline- & 371 & 56 & 598 & 91 \\
\hline- & 658 & 100 & 658 & 100 \\
\hline
\end{tabular}

II

komplikaties circa 3 maanden na MI

\begin{tabular}{lcc}
\hline & $n$ & \\
direkt in relatie & 78 & 13 \\
tot infarct & & \\
bloedsomloop alge- & 30 & 5 \\
meen (bv. hypertensie) & 11 & 2 \\
psychische reakties & 13 & 2 \\
bypass operatie & 468 & 78 \\
geen & 58 & \\
onbekend & & \\
\hline
\end{tabular}


III

beroepsniveau

\begin{tabular}{lrr}
\hline & $n$ & \\
laag: ongeschoolde arbeid & 92 & 14 \\
geschoolde arbeid & 192 & 29 \\
lagere employees & 171 & 26 \\
hoog: middelbare employees & 147 & 22 \\
hoge beroepen & 56 & 9 \\
\cline { 2 - 3 } & 658 & 100 \\
\hline
\end{tabular}

IV: Geschatte belasting arbeidstaak

energetisch $\begin{gathered}\text { perceptief } \\ \text { mentaal }\end{gathered}$ psychosociaal

\begin{tabular}{lrccccc}
\hline & $\mathrm{n}$ & $\mathrm{g}$ & $\mathrm{n}$ & \% & $\mathrm{n}$ & \% \\
licht & 365 & 56 & 242 & 37 & 304 & 48 \\
middelmatig & 216 & 33 & 306 & 47 & 235 & 37 \\
zwaar & 70 & 11 & 101 & 16 & 98 & 15 \\
\hdashline & 651 & 100 & 649 & 100 & 637 & 100 \\
onbekend & 7 & & 9 & & 21 & \\
\hline
\end{tabular}


Bijlage 7:

I. Variabelen en korrelatiematrix regressie-analyses niet/ wel hervat (tabel 4.14) en algemene tevredenheid (tabel. 5.7) (CARGO-onderzoek).

\begin{tabular}{|c|c|c|c|c|}
\hline Variabele & kodering & $\overline{\mathrm{x}}$ & s.d. & min.-mäx. \\
\hline leeftija & jaxen & 52.5 & 6.6 & $25-65$ \\
\hline beroep & ITS-kode & 2.8 & 1.2 & $1-5$ \\
\hline $\mathrm{AP}$ & $\begin{array}{l}0=a \text { fwezig } \\
1=\text { aanwezig }\end{array}$ & .44 & .50 & - \\
\hline cardiale kompl. & $0-1$ & .16 & .36 & - \\
\hline recidief infarct & $0-1$ & .09 & .29 & - \\
\hline opnameduur & dagen & 23.3 & 10.6 & $2-68$ \\
\hline $\begin{array}{l}\text { fysieke reva- } \\
\text { lidatie }\end{array}$ & $\begin{array}{l}0=\text { geen } / \text { kort } / \\
1=\text { vroeg }\end{array}$ & laat.11 & .32 & - \\
\hline hervatting & $0-1$ & .67 & .47 & - \\
\hline $\begin{array}{l}\text { algemene } \\
\text { tevredenheid }\end{array}$ & matig-goed & 1.96 & .76 & $1-3$ \\
\hline
\end{tabular}

Korrelatiematrix, Pearson-korrelaties x100 ( $n=658)$

leeft. beroep AP kompl recid, opnamed. reval. herv. tevr. leeft. --

$\begin{array}{lrrrrrrrr}\text { beroep } & 01 & -- & & & & & \\ \text { AP } & 15 & -17 & -- & & & & \\ \text { kompl. } & -02 & 02 & 06 & -- & & & \\ \text { recid. } & 04 & 09 & 11 & 04 & -- & & & \\ \text { opnamed. } & -07 & -07 & -00 & 15 & 04 & -- & & \\ \text { reval. } & -07 & -03 & -00 & -07 & -03 & -11 & -- & \\ \text { herv. } & -34 & 24 & -33 & -11 & -10 & -08 & 12 & -- \\ \text { tevr. } & -16 & 28 & -32 & -16 & -02 & -13 & 12 & 43\end{array}$


II: Variabelen en korrelatiematrix regressie-analyses ander/eigen werk en interval infarct-hervatting (tabel 4.14).

\begin{tabular}{llccc}
\hline variabele & kodering & $\bar{x}$ & s.d. & min.-max. \\
\hline beroep & ITS-kode & 3.0 & 1.2 & $1-5$ \\
AP & $0-1$ & .31 & .46 & - \\
cardiale kompl. & $0-1$ & .11 & .34 & - \\
opnameduur & dagen & 23.1 & 9.5 & $2-62$ \\
ander/eigen werk & $0-1$ & .67 & .47 & - \\
interval & maanden & 5.4 & 2.6 & $1-15$ \\
\hline
\end{tabular}

Korrelatiematrix, Pearson-korrelaties x100 (n=444)

beroep AP kompl. opnamed. ander/eigen interval

\begin{tabular}{|c|c|c|c|c|c|}
\hline beroep & -- & & & & \\
\hline $\mathrm{AP}$ & -11 & -- & & & \\
\hline kompl. & 17 & 07 & -- & & \\
\hline $\begin{array}{l}\text { opnamed. } \\
\text { ander/ }\end{array}$ & -01 & -05 & 12 & -- & \\
\hline eigen & 18 & -13 & -15 & -08 & - \\
\hline interval & -04 & 11 & 17 & 15 & -06 \\
\hline
\end{tabular}


II : Variabelen en korrelatiematrix regressie-analyses gedeeltelijk/geheel hervat (tabel 4.14 ) en geslaagde hervatting (tabel 4.22 ).

\begin{tabular}{|c|c|c|c|c|}
\hline variabele & kodering & $\bar{x}$ & $s \cdot d$ & min. -max. \\
\hline leeftijd & jaren & 50.9 & 6.5 & $25-64$ \\
\hline beroep & ITS-kode & 3.0 & 1.2 & $1-5$ \\
\hline $\mathrm{AP}$ & $0-1$ & .31 & .46 & - \\
\hline cardiale kompl. & $0-1$ & .11 & .31 & - \\
\hline fysieke reval. & $0-1$ & .14 & .35 & - \\
\hline $\begin{array}{l}\text { zwaarte arbeid } \\
\text { vö́r infaxct }\end{array}$ & $\begin{array}{l}\text { sommering } 3 \\
\text { afzonderl. } \\
\text { aspekten }\end{array}$ & 5.1 & 1.3 & $3-9$ \\
\hline $\begin{array}{l}\text { gedee1t. /geheel } \\
\text { niet geslaagd/ } \\
\text { geslaagd }\end{array}$ & $0-1$ & .56 & .50 & - \\
\hline
\end{tabular}

Korrelatiematrix, Pearson-korrelaties $\mathrm{x} 100 \quad(\mathrm{n}=444)$

leeftijd beroep AP kompl zwarte reval geheel geslaagd

leeftijd

beroep

$A P$

kompl.

zwarte

reval.

geheel

geslaagd

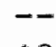

10

09

$-03$

$-09$

$-04$

$-11$

07

$\begin{array}{rrr}-- & & \\ -11 & -- & \\ 17 & 07 & -- \\ 29 & -06 & 04 \\ -02 & 05 & 04 \\ 17 & -25 & -07 \\ 13 & -11 & -13\end{array}$

--
04
-07

--
10
05

26


IV: Variabelen en korrelatiematrix regressie-analyses oordeel patiënt/arts over sukses hervatting (tabel 5.2).

\begin{tabular}{llccc}
\hline variabele & kodering & $\bar{x}$ & s.d. & min.-max. \\
\hline tevredenheid leven matig-goed & 3.5 & .73 & $1-4$ \\
tevredenh.konditie matig-goed & 3.2 & .81 & $1-4$ \\
ander/elgen werk & $0-1$ & .64 & .48 & - \\
verzuimde dagen & dagen & 13.0 & 37.5 & $2-120$ \\
gedeelt. /geheel & $0-1$ & .56 & .50 & - \\
interval & maanden & 5.4 & 2.6 & $1-15$ \\
opnameduur & dagen & 23.0 & 9.5 & $2-62$ \\
oordeel patiënt & $\begin{array}{l}\text { niet geslaagd' } \\
\text { geslaagd }\end{array}$ & 3.4 & .78 & $1-4$ \\
idem & 3.4 & .79 & $1-4$ \\
\hline
\end{tabular}

Korrelatiematrix, Pearson-korrelaties x100 $\quad(n=432)$

tevredenheid

oorder

leven konditie eigenw verzuim geheel interv. opname pat.al

Leven

konditie

elgenw..

verzuim

gehee1

interval

opnamed.

patiënt

arts

53
16
-14
30
-14
-14
51
55

55

$\begin{array}{rrr}-- & & \\ 20 & -- & \\ -25 & -12 & -- \\ 42 & 20 & -20 \\ -08 & -07 & 01 \\ -19 & -09 & 01 \\ 53 & 33 & -33 \\ 62 & 27 & -30\end{array}$

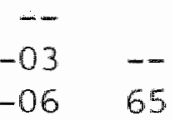




\section{Bijlage 8:}

Diskriminant-analyses partiële ordening (fig. 4) beoordelingen sukses hervatting (CARGo-onderzoek).

I. Vergelijking arts -, patient -/arts +, patiënt -

Variabele

tevredenheid konditie

geheel hervat

tevredenheid leven

verzuimde dagen

1 funktie; ejgenwaarde .94. Kan.korrelatie .70, $0<.01$

II. Vergelijking arts -, patiënt -/arts -, patiënt +. gestandaard. diskriminant-koëff.
.57

.42

.40

$-.31$

Variabele

gestandaard. diskriminant-koëff.

tevredenheid leven

.50

verzuimde dagen

$-.39$

geheel hervat

.37

tevredenheid konditie

.30

1 funktie; eigenwaarde .47. Kan.korrelatie .56, p<.01

III. Vergelijking arts + , patiënt-/arts + , patiënt + .

Variabele

gestandaard. diskriminant-koëff.

eigen werk

tevredenheid leven

.67

interval

.47

tevredenheid konditie

$-.38$

.38

1 funktie; eigenwaarde .41. Kan. korrelatie .54, p<.01 
IV: Vergelijking arts -, patiënt +/arts +, patiënt +.

variabele gestandaard. diskriminant-koëff.

tevredenheid konditie .57

tevredenheid leven

.42

geheel hervat

.30

eigen werk

.27

1 funktie; eigenwaarde .53. Kan.korrelatie .59, p $<.01$ 
Bijlage 9:

I: Verloop in de watt max in revalidatie- en kontrolegroep (Leidse onderzoek).

\begin{tabular}{|c|c|c|c|c|c|}
\hline maanden na $\mathrm{MI}$ & & 3 & 6 & 12 & 24 \\
\hline revalidatie & $\begin{array}{r}\bar{x} \\
s . d . \\
\min . \max \end{array}$ & $\begin{array}{l}\frac{145.5}{26.5} \\
97-190\end{array}$ & $\begin{array}{l}\frac{172.6}{31.2} \\
120-240\end{array}$ & $\begin{array}{l}\frac{155.9}{35.7} \\
85-215\end{array}$ & $\begin{array}{l}\frac{150.0}{34.6} \\
93-220\end{array}$ \\
\hline kontrole & $\begin{array}{r}\bar{x} \\
s . \bar{d} \\
\min .-\max \end{array}$ & $\begin{array}{l}\frac{157.5}{32.1} \\
105-220\end{array}$ & $\begin{array}{l}\frac{161.1}{35.1} \\
107-240\end{array}$ & $\begin{array}{l}\frac{166.2}{28.9} \\
113-230\end{array}$ & $\begin{array}{r}\frac{164.6}{26.4} \\
114-21\end{array}$ \\
\hline
\end{tabular}

II: Verloop in de aktiviteitsgraad in revalidatie- en kontrolegroep (Leidse onderzoek).

\begin{tabular}{llllll}
\hline maanden na MI & 0 & 3 & 6 & 12 & 24 \\
\hline revalidatie $\overline{\mathrm{x}}$ & $\frac{2.32}{.52}$ & $\frac{1.79}{.16}$ & $\frac{1.85}{.25}$ & $\frac{1.90}{.40}$ & $\frac{1.90}{.30}$
\end{tabular}

min-max.1.64-3.34 1.56-2.20 $1.542 .40 \quad 1.49-2.73 \quad 1.49-2.60$

kontrole

$\bar{x} \quad \frac{2.37}{.42} \quad \frac{1.80}{.27} \quad \frac{1.86}{.33}$

$\frac{1.95}{.31}$

$\frac{2.08}{.32}$

$\min -\max .1 .72-3.45 \quad 1.49-2.20 \quad 1.45-2.62$

1.272 .62

$1.55-2.62$ 
Bijlage 10:

Psychometrische eigenschappen van de PET-schaal. (op basis van meting drie maanden na $M I, n=51$ ).

Guttman's kriteria:

$$
\begin{aligned}
\text { rep. } & =.94 \\
\text { rep. } & \text { min. }=.72 \\
\text { rep. } \text { kans } & =.89
\end{aligned} \quad \mathrm{z}=3.03 \mathrm{p}<.01
$$

Betrouwbaarheid:

$$
\alpha=.71
$$

standaard-meetfout $=.78$

$$
\text { hertest }=.74 \quad \begin{gathered}
\text { (gemiddeld over } 4 \\
\text { metingen) }
\end{gathered}
$$

Geldigheid: $\mathrm{PET}_{3}-$ watt $\max _{3} \quad r=.31$

- akt.graad $\quad r=.34$

$-\mathrm{SB}_{3} \quad \mathrm{r}=-.57$

$\mathrm{PET}_{3}$ - watt $\max _{12} \quad r=.38$

- akt.graad $12 \quad r=.37$

- werk hervat ${ }_{12} r=.57$

Alle geldigheidskoëfficiënten zijn signifikant op minstens 5:-niveau. 
Bijlage 11:

verloop in de aard van de door de vrouw verzonden signalen aan de man (abs, aantallen). (Leidse onderzoek)

\begin{tabular}{|c|c|c|c|c|c|c|c|c|}
\hline \multirow[b]{2}{*}{ maanden na MI } & \multicolumn{4}{|c|}{ revalidatie } & \multicolumn{4}{|c|}{ kontrole } \\
\hline & 3 & 6 & 12 & 24 & 3 & 6 & 12 & 24 \\
\hline aanmoediging & 9 & 9 & 7 & 7 & 7 & 4 & 4 & 5 \\
\hline afkeuring & 5 & 5 & 2 & 3 & 6 & 3 & 4 & 8 \\
\hline $\begin{array}{l}\text { aanmoediging }+ \\
\text { afkeuring }\end{array}$ & 5 & 5 & 4 & 3 & 7 & 8 & 7 & 6 \\
\hline $\begin{array}{l}\text { overeenstemming } \\
(\hat{\mathrm{K}})\end{array}$ & .07 & .09 & .24 & .22 & .25 & .13 & .24 & .14 \\
\hline
\end{tabular}




\section{Bijlage 12:}

Kenmerken hervatters/niet hervatters naar revalidatie (Leldse onderzoek).

Watt max.

maanden na $M I$

3

6

12

24

hervat: revalidatie

kontrole

$\begin{array}{crrrr}\bar{x} & \frac{164.3}{19.9} & \frac{193.8}{23.4} & \frac{180.4}{22.4} & \frac{172.6}{24.6} \\ \text { s.d. } & \frac{172.6}{29.7} & \frac{177.5}{32.3} & \frac{181.6}{23.4} & \frac{175.6}{22.3}\end{array}$

niet hervat:

\begin{tabular}{|c|c|c|c|c|c|}
\hline revalidatie & $\bar{x}$ & 128.5 & 151.5 & 131.4 & 125.5 \\
\hline & s.d. & 17.6 & 22.5 & 29.1 & 26.4 \\
\hline kontrole & $\bar{x}$ & 133.5 & 137.2 & 143.6 & 148.6 \\
\hline & s.a. & 21.6 & 23.3 & 20.2 & 24.4 \\
\hline
\end{tabular}

Maximale hartfrekwentie

\begin{tabular}{|c|c|c|c|c|c|c|}
\hline maanden & $\operatorname{na} M I$ & & 3 & 6 & 12 & 24 \\
\hline \multirow[t]{4}{*}{ hervat: } & revalidatie & $\bar{x}$ & 152.2 & 160.3 & 155.3 & 155.3 \\
\hline & & s.d. & 25.0 & 20.8 & 16.3 & 17.2 \\
\hline & kontrole & $\bar{x}$ & 160.9 & 164.7 & 156.5 & 162.8 \\
\hline & & s.d. & 24.1 & 18.7 & 16.6 & 17.1 \\
\hline
\end{tabular}

niet hervat:
revalidatie

$\begin{array}{lrrrr}\bar{x} & \frac{142.2}{17.0} & \frac{145.8}{18.0} & \frac{135.3}{22.0} & \frac{135.6}{19.3} \\ \text { s.d. } & \frac{141.7}{18.3} & \frac{136.8}{22.9} & \frac{139.0}{20.9} & \frac{141.3}{24.9}\end{array}$
kontrole 
Aktiviteitsgraad

\begin{tabular}{|c|c|c|c|c|c|c|}
\hline Maanden na & MI & 0 & 3 & 6 & 12 & 24 \\
\hline \multicolumn{7}{|l|}{ hervat: } \\
\hline \multirow[t]{2}{*}{ revalidatie } & $\bar{x}$ & 2.32 & 1.80 & 1.94 & 2.00 & 2.00 \\
\hline & s.d. & .60 & .19 & .26 & .45 & .37 \\
\hline \multirow[t]{2}{*}{ kontrole } & $\bar{x}$ & 2.32 & 1.87 & 1.97 & 2.00 & 2.19 \\
\hline & $s \cdot d$ & $\overline{.34}$ & .27 & .34 & .32 & .30 \\
\hline \multicolumn{7}{|l|}{ niet hervat: } \\
\hline \multirow[t]{2}{*}{ revalidatie } & $\bar{x}$ & 2.33 & 1.77 & 1.75 & 1.81 & 1.80 \\
\hline & s.a. & .45 & .13 & .21 & .33 & .18 \\
\hline \multirow[t]{2}{*}{ kontrole } & $\bar{x}$ & 2.44 & 1.75 & 1.79 & 1.86 & 1.91 \\
\hline & s.d. & .53 & .26 & .32 & .31 & .29 \\
\hline
\end{tabular}

Subjektieve belasting (SB)

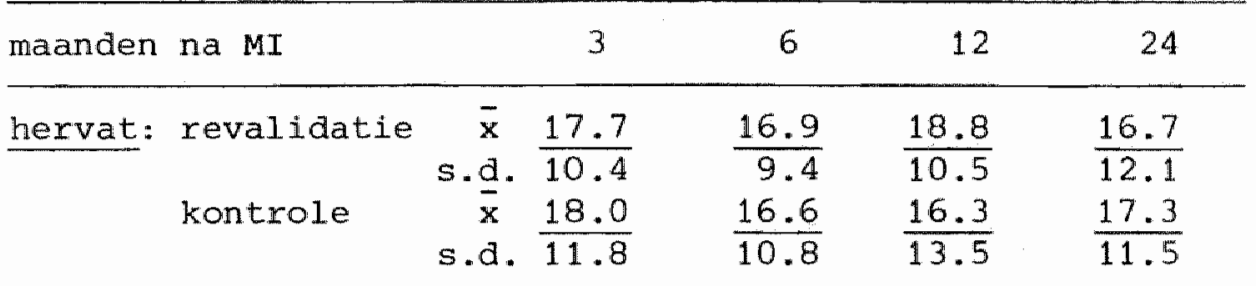

niet hervat:

\begin{tabular}{|c|c|c|c|c|c|}
\hline \multirow{2}{*}{ revalidatie } & $\bar{x}$ & 28.2 & 33.4 & 32.6 & 29.4 \\
\hline & s.d. & 5.6 & $\overline{8.3}$ & 9.5 & 9.7 \\
\hline \multirow[t]{2}{*}{ kontrole } & $\vec{x}$ & 25.2 & 30.2 & 27.6 & 28.7 \\
\hline & s.d. & $\overline{8.4}$ & 10.6 & 10.5 & 10.8 \\
\hline
\end{tabular}


Gepercipieerde inspanningstolerantie (PET)

\begin{tabular}{|c|c|c|c|c|c|c|}
\hline maanden & na $M I$ & & 3 & 6 & 12 & 24 \\
\hline \multirow[t]{4}{*}{ hervat: } & revalidatie & $\overline{\mathrm{x}}$ & 3.8 & 4.9 & 4.2 & 4.6 \\
\hline & & s.d. & $\overline{1.7}$ & $\overline{1.2}$ & $\overline{1.6}$ & $\overline{1.8}$ \\
\hline & kontrole & $\bar{x}$ & 4.4 & 5.1 & 4.8 & 4.8 \\
\hline & & s.d. & $\overline{1.5}$ & $\overline{1.3}$ & $\overline{1.6}$ & $\overline{1.3}$ \\
\hline
\end{tabular}

niet hervat:

\begin{tabular}{|c|c|c|c|c|c|}
\hline \multirow{2}{*}{ revalidatie } & $\bar{x}$ & 2.8 & 2.7 & 3.0 & 3.0 \\
\hline & s.d. & $\overline{1.3}$ & $\overline{1.6}$ & $\overline{1.5}$ & $\overline{1.4}$ \\
\hline \multirow[t]{2}{*}{ kontrole } & $\bar{x}$ & 2.9 & 3.0 & 3.6 & 3.5 \\
\hline & s.d. & $\overline{1.5}$ & $\overline{1.5}$ & $\overline{1.4}$ & 1.6 \\
\hline
\end{tabular}

Participatie huishouden

\begin{tabular}{|c|c|c|c|c|c|c|}
\hline maanden & na $M I$ & & 3 & 6 & 12 & 24 \\
\hline \multirow[t]{3}{*}{ hervat: } & revalidatie & $\overline{\mathrm{x}}$ & .31 & .32 & .31 & .38 \\
\hline & & s.d. & .21 & .25 & $\overline{.12}$ & .22 \\
\hline & kontrole & $\begin{array}{c}\bar{x} \\
\text { s.d. }\end{array}$ & $\frac{.33}{.15}$ & $\frac{.40}{.20}$ & $\frac{.36}{.21}$ & $\frac{.37}{.20}$ \\
\hline
\end{tabular}

niet hervat:

\begin{tabular}{|c|c|c|c|c|c|}
\hline revalidatie & $\bar{x}$ & .31 & .40 & .44 & .42 \\
\hline & s.d. & .33 &.$\overline{33}$ & .32 & .26 \\
\hline kontrole & $\bar{x}$ & .43 & .41 & .49 & .55 \\
\hline & s.d. & .27 & .27 & .26 & .21 \\
\hline
\end{tabular}


Aktieve vrijetijasbesteding

\begin{tabular}{|c|c|c|c|c|c|c|}
\hline maanden & $\mathrm{na} M I$ & & 3 & 6 & 12 & 24 \\
\hline \multirow[t]{4}{*}{ hervat: } & revalidatie & $\bar{x}$ & 8.6 & 9.6 & 8.6 & 8.5 \\
\hline & & s.d. & 3.9 & $\overline{3.8}$ & $\overline{3.9}$ & $\overline{3.5}$ \\
\hline & kontrole & $\bar{x}$ & 10.0 & 11.3 & 10.5 & 10.2 \\
\hline & & s.d. & 3.3 & $\overline{2.6}$ & 2.3 & 2.6 \\
\hline
\end{tabular}

niet hervat:

\begin{tabular}{|c|c|c|c|c|c|}
\hline \multirow[t]{2}{*}{ revalidatie } & $\bar{x}$ & 7.4 & 7.6 & 8.3 & 8.3 \\
\hline & s.d. & 2.5 & $\overline{1.8}$ & $\overline{1.7}$ & 2.4 \\
\hline \multirow[t]{2}{*}{ kontrole } & $\bar{x}$ & 8.4 & 8.1 & 8.9 & 9.0 \\
\hline & s.a. & $\overline{4.3}$ & 2.7 & $\overline{4.2}$ & 3. \\
\hline
\end{tabular}


De auteur van dit proefschrift werd op 25 augustus 1944 geboren te Rotterdam.

Na het behalen van de diploma"s MULo a en b in 1960, werd in 1963 het elndexamen HBS-b behald aan het St. Franciscuscollege te Rotterdam.

Na militaire dienst en een jaar studie natuur- en scheikunde aan de Rijksuniversiteit Leiden werd in $1965 \mathrm{bij}$ dezelfde universiteit de studie westerse Sociologie begonnen. Het doctoraal examen werd in januari 1971 behaald, met als hoofdvak empirische en wijsgerige sociologie en als bijvakken sociale psychologie en methoden en technieken van onderzoek.

Van februari 1971 tot januari 1975 was de auteur als wetenschappelijk medewerker verbonden aan het NIPG/TNO te Leiden.

Sedert januari 1975 is hij werkzaam bij de capaciteitsgroep Medische Sociologie aan de Rijksuniversiteit Limburg. 